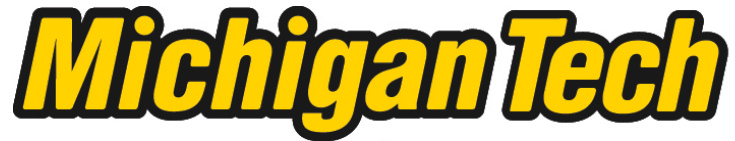 \\ Michigan Technological University Create the Future Digital Commons @ Michigan Tech
}

2015

RESTORATION OF HEADWATER AND COASTAL FENS IN THE LAKE SUPERIOR BASIN OF UPPER MICHIGAN

James A. Bess

Michigan Technological University

Follow this and additional works at: https://digitalcommons.mtu.edu/etds

Part of the Environmental Monitoring Commons, and the Forest Sciences Commons Copyright 2015 James A. Bess

\section{Recommended Citation}

Bess, James A., "RESTORATION OF HEADWATER AND COASTAL FENS IN THE LAKE SUPERIOR BASIN OF UPPER MICHIGAN", Dissertation, Michigan Technological University, 2015.

https://doi.org/10.37099/mtu.dc.etds/1004

Follow this and additional works at: https://digitalcommons.mtu.edu/etds

Part of the Environmental Monitoring Commons, and the Forest Sciences Commons 


\title{
RESTORATION OF HEADWATER AND COASTAL FENS IN THE LAKE SUPERIOR BASIN OF UPPER MICHIGAN
}

\author{
By \\ James A. Bess
}

\begin{abstract}
A DISSERTATION
Submitted in partial fulfillment of the requirements for the degree of DOCTOR OF PHILOSOPHY

In Forest Science
\end{abstract}

MICHIGAN TECHNOLOGICAL UNIVERSITY

2015

(C) 2015 James A. Bess 
This dissertation has been approved in partial fulfillment of the requirements for the Degree of DOCTOR OF PHILOSOPHY in Forest Science.

School of Forest Resources and Environmental Science

Dissertation Advisor: Dr. Rodney A. Chimner

Committee Member: Dr. Casey Huckins

Committee Member: Dr. Andrew Storer

Committee Member: Dr. Christopher Webster

School Dean: $\quad$ Dr. Terry L. Sharik 


\section{TABLE OF CONTENTS}

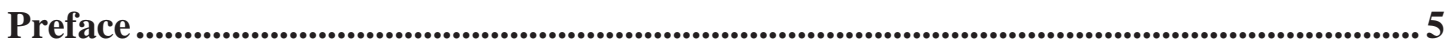

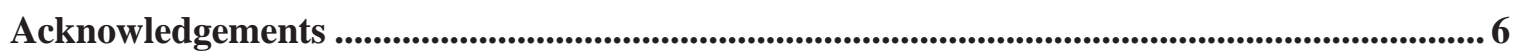

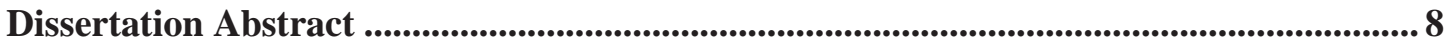

Chapter 1.0: Introduction ..................................................................................................................9 9

1.1 Fen Characterization and Distribution .................................................................................. 9

1.2. Fen Classification and Pore Water Chemistry .................................................................. 10

1.3 Fen Degradation, Conservation and Restoration ...................................................... 12

1.4 Project Overview ................................................................................................. 14

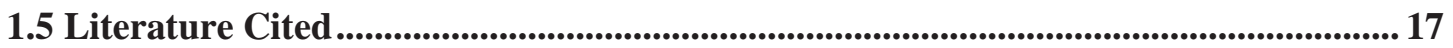

Chapter 2.0 Ditch Restoration in a Large Northern Michigan Fen: Vegetation Response and Basic Pore water Chemistry ${ }^{1}$..................................................................................................... 32

2.1 Abstract ................................................................................................................................. 32

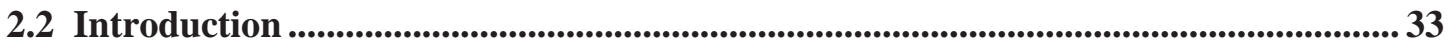

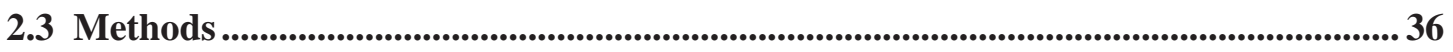

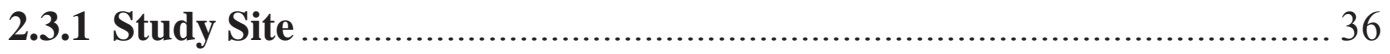

2.3.2 Ditch Filling/Peat Replacement .................................................. 38

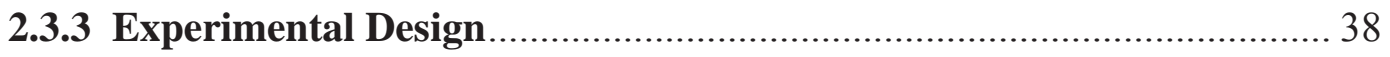

2.3.4 Seed and Moss Collection and Planting ........................................... 39

2.3.5 Groundwater Monitoring and Pore water Sampling ......................... 41

2.3.6 Vegetation Monitoring and Statistical Analysis............................... 43

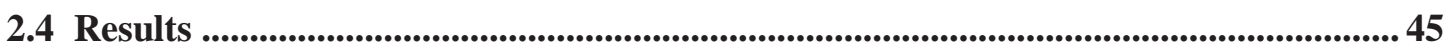

2.4.1 Depth to Water Table and Pore Water Chemistry ............................. 45

2.4.2 Vegetation Results - 2010 ............................................................. 46

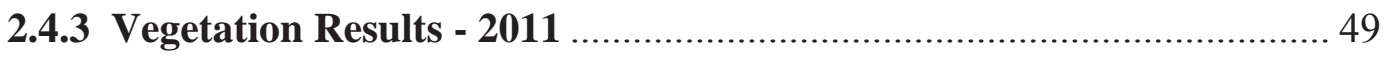

2.4.4 Vegetation, $\mathrm{pH}$ and Electrical Conductivity .................................. 50

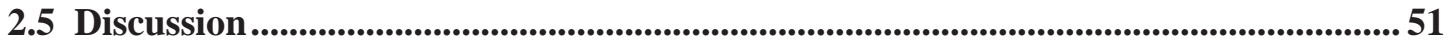

2.6 Implications for Practice.......................................................................................................... 53

2.7 Acknowledgements ......................................................................................................... 56

2.8 Literature Cited ................................................................................................................... 57

Chapter 3.0 Gradients in Pore water Chemistry and Vegetation in a Restored Northern Michigan Fen ${ }^{2}$........................................................................................................................................ 85

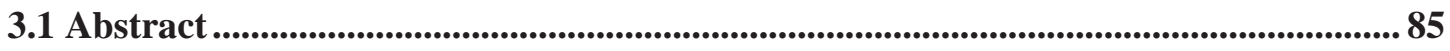




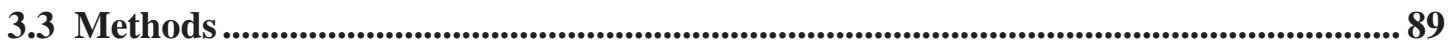

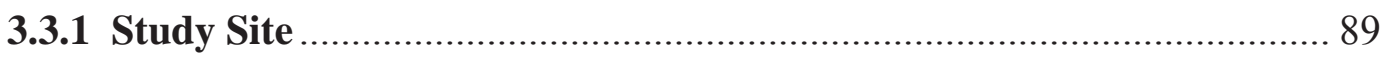

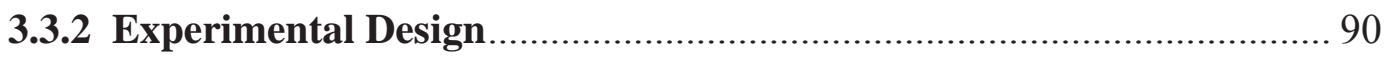

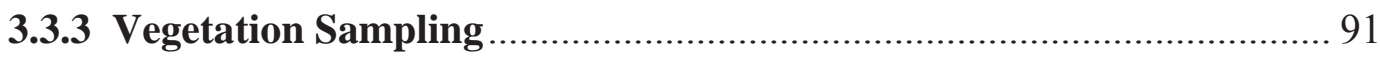

3.3.4 Pore water Sampling and Analysis................................................ 93

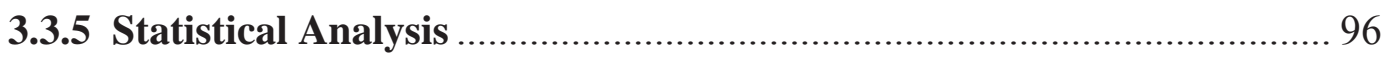

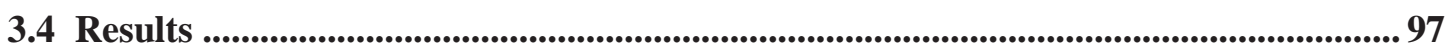

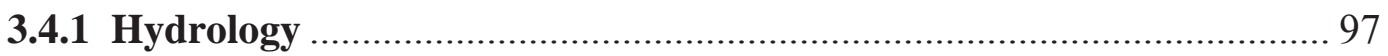

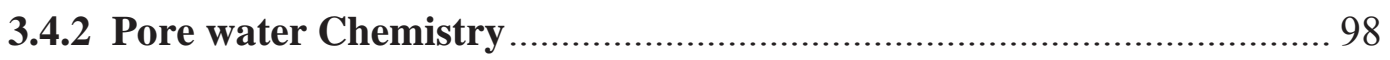

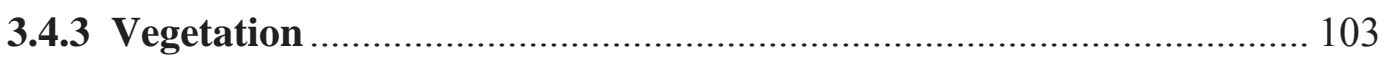

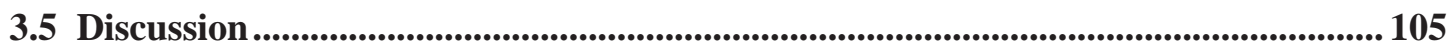

3.6 Implications for Practice.......................................................................................... 113

3.7 Acknowledgements .............................................................................................................. 115

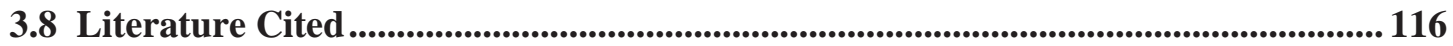

Chapter 4.0 A Novel Approach to Establishing Coastal Wetlands on the Southern Shore of

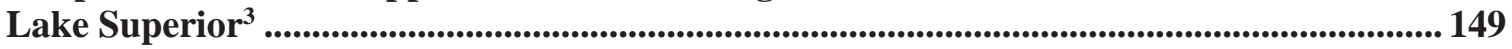

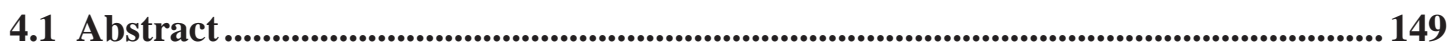

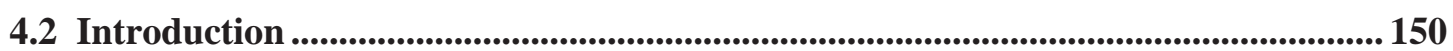

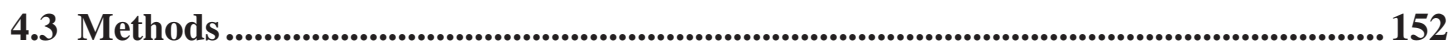

4.3.1 Site Selection and Preparation..................................................... 152

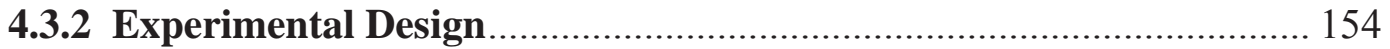

4.3.3 Seed Stock and Treatment ......................................................... 155

4.3.4 Zone Construction and Seeding.................................................... 157

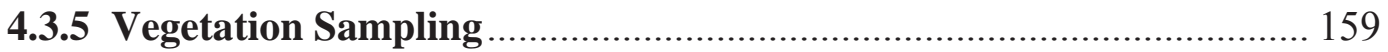

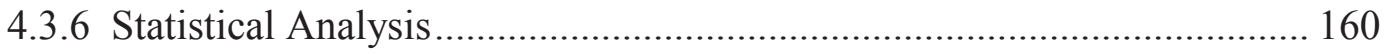

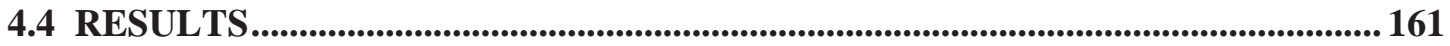

4.4.1 Water Levels in Lake Superior.................................................... 161

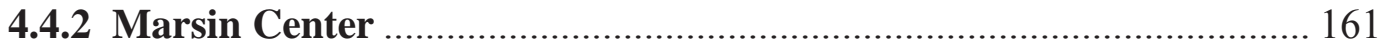

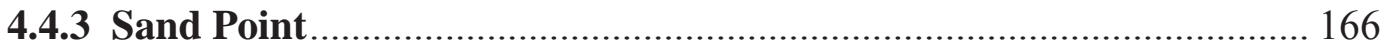

4.5 Discussion and Implications for Practice ................................................................. 170

4.6 Acknowledgements .................................................................................................................. 173

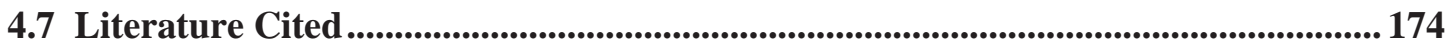




\section{Preface}

This dissertation is based on the following papers as referred by their chapter number, which are either published or in preparation for submission to ecological journals. Text throughout the document is written in first person plural to recognize the contribution of multiple authors. For the Chapter 2 paper, James Bess wrote grants for funding, designed and implemented the experiments, collected and analyzed all data and performed the bulk of the writing and editing. Dr. Rodney Chimner assisted with funding, developing experimental design, construction of experiments, analyzing data and writing. Laura Kangas assisted with constructing experiments, collecting and analyzing data and report writing. For the Chapter 3 paper, James Bess wrote grants for funding, designed and implemented the experiments, collected and analyzed all data and performed the bulk of the writing and editing. Dr. Rodney Chimner assisted with funding, developing experimental design, construction of experiments, analyzing data and writing. Dr. John Hribljan assisted with data collection, analysis and report writing, while Dr. Evan Kane assisted with data collection and analysis. In the Chapter 4 paper, James Bess wrote grants for funding, designed and implemented the experiments, collected and analyzed all data and performed the bulk of the writing and editing. Dr. Rodney Chimner and Dr. Casey Huckins assisted with funding, developing experimental design, analyzing data and writing.

Chapter 2. Bess, J., R. Chimner and L. Kangas. Ditch restoration in a large northern Michigan fen: vegetation response and basic pore water chemistry. Ecological Restoration 32(3): 260-274. ISSN 1522-4740 E-ISSN 1543-4079. 
Chapter 3. Bess, J., R. Chimner, J. Hribljan and E. Kane. 2015. Gradients in pore water chemistry and vegetation in a restored northern Michigan fen. Manuscript.

Chapter 4. Bess, J, C. Huckins. and R. Chimner. 2015. A novel approach to establishing coastal wetlands on the south shore of Lake Superior. Manuscript.

\section{Acknowledgements}

The completion of this dissertation was successful because of the support, financial backing, and encouragement of multiple individuals. I would first like to thank my advisor Dr. Rodney Chimner for his patience and guidance throughout this endeavor. I would also like to thank my committee members Dr. Casey Huckins, Dr. Andrew Storer, and Dr. Christopher Webster who gave me valuable insights and direction. Dr. Andy Burton generously provided use of his laboratory facilities and Jennifer Eikenberry and Dr. Evan Kane provided invaluable assistance in the processing of pore water samples. I also received assistance from many students with field and laboratory work including Arvo Aljaste, Tamara Baker, Ellen Beller, Jennifer Bush, Erin Grupido, John Hribljan, Laura Kangas, Margus Pesaelu and Rose Schwartz. Thanks also go to the University of Wisconsin press for permission to include and reprint my Chapter 2 research, which was previously published in their journal, Ecological Restoration. Their permission letter is included in Appendix 1.

Funding for this research was provided by Michigan Technological University, The Nature Conservancy, Michigan DNR and the U.S. EPA Great Lakes Restoration 
Initiative. The Nature Conservancy also provided us with maps, results of previous botanical surveys and on-site lodging. The Keweenaw Land Trust and Keweenaw Bay Indian Community were most generous in allowing me to use their properties for my coastal wetland restoration experiments. And finally, I would like to give special recognition to my wife Karen Bess for her endless support and encouragement. Without her help this dissertation would not have been possible. Thank you. 


\section{Dissertation Abstract}

In 2009, research projects were initiated at Michigan Technological University to develop restoration techniques for headwater fens and coastal wetlands in the southern Lake Superior Basin in Michigan's Upper Peninsula. The primary focus of these was to quantify the efficacy of using locally collected seeds as a technique for wetland restoration. Two primary sites were selected, the Sleeper Lake Fen complex in Luce County and the Portage Waterway-Keweenaw Bay region of Lake Superior in Baraga and Houghton Counties. At the Sleeper Lake site, a combination of heavy machinery, seeding and mulch application was used to restore a $1.6 \mathrm{~km}$ ditch through a formerly pristine headwater fen. Pore water chemistry was measured in the undisturbed and restored fen to compare with vegetation data collected from the same locations for two growing seasons following restoration. At the two coastal sites along the Portage Waterway and Keweenaw Bay, a combination of seeds, natural fiber geotextiles and organic soil amendment (milled Sphagnum peat moss) were tested for restoration efficacy along 2, 33-m long sectors of shoreline, one site along the Portage Waterway in Houghton County and another along a former interdunal pond adjacent to Keweenaw Bay in Baraga County. Vegetation data were collected for three years following restoration. Both projects were successful in restoring diverse assemblages of native plants. At the Sleeper Lake site, pore water chemistry was found to correlate closely with several vegetative parameters and at the Portage Waterway and Keweenaw Bay sites, the organic amendment had variable results in enhancing vegetative establishment and survival. Fluctuating lake levels were important in determining vegetative establishment and 
survival at the sites along Lake Superior. The results of these experiments are compared with other similar projects and discussed in relation to local conditions and potential for extrapolation across the Great Lakes region.

\section{Chapter 1.0: Introduction}

\subsection{Fen Characterization and Distribution}

Prior to the industrial revolution, peatlands covered roughly 4 million $\mathrm{km}^{2}$ or $3 \%$ of the Earth's land surface (Maltby and Proctor 1996). Peatlands were distributed across much of Siberia, northern Europe, Canada and the eastern US. In the tropics, peatlands occurred in parts of the Amazon and Congo river basins, Indonesia and Malaysia, while montane peatlands were found throughout Europe, South America, North America and parts of Africa, Australia and New Zealand. Siberia and Canada still contain large areas of fairly pristine peatland, but many thousands of hectares have been destroyed or negatively affected by forestry and mining activity, hydroelectric projects, atmospheric nitrogen deposition, wildfire and global climate change (Kremenetski et al., 2003, Poulin et al., 2004, Frey and Smith, 2005). In addition, a major reduction in peatland acreage has occurred in the tropics, Western Europe and the U.S. over the past 400 years (Wheeler, 1897, Parish et al., 2008, Keddy et al., 2009, Bain et al., 2011, Borlick, 2013).

Fens are peatlands characterized (in part) by their strong association with flowing groundwater and surface water (Crum, 1988, Amon et al., 2002, Bedford and Godwin, 2002, Rydin and Jeglum, 2006, Wieder and Vitt, 2006, Parish et al., 2008). These natural communities typically occur at breaks in stratigraphy or topography that create 
hydrologic gradients, forcing ground water to approach or be released on the surface of the land (Amon et al., 2002). These groundwater release points have been referred to as “aquifer windows" (Wilcox et al., 1986).

In the Upper Midwest of North America, fens occur primarily on glacial till deposits, where groundwater passes through mixtures of rock, sand, silt and clay, acquiring dissolved minerals along the way (Almendinger and Leete, 1998a-b). In particular, as the glaciers passed south over the Niagaran Escarpment surrounding the northern Great Lakes, these large masses of ice ground down the limestone and dolomite bedrock forming much of this feature and incorporated an abundance of calcium and magnesium carbonates in the glacial till left when they receded (Boelter and Verry, 1977, Amon et al., 2002).

\subsection{Fen Classification and Pore Water Chemistry}

Given that the composition of glacial till is not uniform across the Midwestern landscape, there is great variation in the chemical composition of groundwater (including surface water) entering fens, as is true of other areas where fens occur (Bridgham et al. 1996, Bedford and Godwin, 2002). Groundwater is here defined as the water flowing from surrounding land into a peatland, pore water is the water occurring in interstitial spaces in saturated/inundated soils (basically groundwater or surface water that has interacted with peat soil and vegetation). Fens are typically described as occurring along a gradient from "poor" to "rich", depending on the $\mathrm{pH}$ and electrochemical composition of the groundwater entering them (following Sjors, 1950, Slack et al. 1980, Swanson and 
Grigal 1991, Heinselman1970, Thormann et al. 1999, McLaughlin and Webster, 2010). Poor fens are those having low $\mathrm{pH}$ and minimal mineral and carbonate content in their groundwater, while rich fens are those with high $\mathrm{pH}$ and increased levels of dissolved minerals, especially iron and carbonates of calcium and magnesium (Thompson, 1993, Almendinger and Leete, 1998b, Amon et al., 2002).

Carbonate ions raise the $\mathrm{pH}$ and (along with other particulate matter) electrical conductivity of groundwater and, in high concentrations, provide conditions that are hostile to the growth of plants not adapted to their presence (Glaser et al., 1990, Gignac et al., 1991, Nekola, 2004). Therefore, rich fens are not only defined by groundwater having increased carbonate and $\mathrm{pH}$, but also by having unique plant assemblages adapted to these conditions (Slack et al. 1980, Motzkin, 1994, Nekola, 2004, Picking and Veneman, 2004). Conversely, poor fens (and bogs) are defined by low $\mathrm{pH}$ and carbonate levels and are vegetated with plant species adapted to more acidic conditions.

Calcium-rich fens are typified by plants often referred to as "calcifiles" or "calciphilic" given their ability to grow and persist in the presence of relatively high concentrations of calcium. Temperate and boreal North American rich fen floras are typically dominated by "brown mosses" (families Amblystegiaceae and others), sedges, grasses and a wide variety of herbaceous plants (or "forbs"), often including many rare or unusual species such as orchids and insectivorous plants (Bedford and Godwin, 2003). Poor fen and bog floras are characterized by many "acidofiles" or "acidophilic" species adapted to low $\mathrm{pH}$ conditions and low nutrient availability. These include Sphagnum mosses (Gignac et al., 1991), certain sedges and a variety of ericaceous shrubs. 
Insectivorous plants like sundews (Drosera spp.) and pitcher plants (Sarracenia spp.) are also often found in these acidic peatlands, although they can be found in certain rich fens as well. Bogs can also contain rare and unusual plant species found nowhere else, although their overall plant species richness is typically much less than that found in fens (Locky and Bayley, 2006, Lamentowicz et al., 2010).

\subsection{Fen Degradation, Conservation and Restoration}

The relatively high nutrient composition and abundant organic matter in fen soils have made these habitats targets for agricultural production for many hundreds (if not thousands) of years (Beltman, et al., 1996, Jensen and Schrautzer, 1999, Lamers et al., 2002, Middleton et al., 2006a, Seer and Schrautzer, 2014). In some cases, these fens have been simply used as pasture or for haying (Wheeler and Giller, 1982, Middleton et al., 2006a-b), but many others have been ditched and drained to allow for peat extraction (Quinty and Rochefort, 2003, Waddington et al., 2009) or the use of heavy machinery to till soil and plant crops (Van Duren et al., 1997, Mälson et al., 2009, Davenport et al., 2014). In Europe and North America, hundreds of thousands of hectares of former fen have been drained and converted to agricultural production (Wheeler, 1897, Fisher et al., 1996, Hartig et al., 1997, Bedford and Godwin, 2002, Middleton et al., 2006b).

The current rarity of fens and their role as habitats for species of conservation concern and headwater protection has fueled a global effort to protect and restore these plant communities over the past $\sim 20$ years (Grootjans and van Diggelen, 1995; Beltman et al., 1996; Hald and Vinther, 2000; Bedford and Godwin, 2002; Lamers et al., 2002; 
Cobbaert et al., 2004; van Diggelen et al., 2006; Drexler et al., 2009; van Loon et al., 2009; Klimkowska et al., 2010; Laine et al., 2011; Sikes et al., 2013; Seer and Schrautzer, 2014; Lamers et al., 2015). Fens also store vast amounts of carbon in their peat and muck soils and this role has further increased the importance of fen restoration in the eyes of governments, regulatory agencies and even the general public (Gorham, 1991; Tuittila et al., 1999; Joosten and Clarke, 2002; Glatzel et al., 2003; Turunen, 2008; Keddy et al., 2009; Komulainen, 2009; Waddington et al., 2009; Anshaari et al., 2010; Armstrong et al., 2010; Kimmel and Mander, 2010; Bain et al., 2011; Whitfield et al., 2011). These unique plant communities often occur at groundwater discharge sites and along the edges of waterways, where their soils and vegetation provide important ecological functions in filtering water, maintaining base flow for lakes, streams and rivers, and providing abundant dissolved organic matter, minerals and nutrients to aquatic systems (Schouwenaars, 1988, Mulqueen, 1986, De Mars and Garritsen, 1997, Schiff et al., 1998, Reeve et al., 2001, Price et al., 2003, Holden et al., 2006, Reeve et al., 2006).

Typically, the first step in fen restoration is to restore (to the level possible) the natural hydrology (Komulainen, 1999; Lode, 1999; Cooper and McDonald, 2000; Tuittila et al., 2000; Holden et al., 2006; Laine et al., 2011; Hedberg et al., 2012; Bork et al., 2013; Schimelpfenig et al., 2014). This can be done through removal of drainage tiles and plugging or filling of drainage ditches in order to re-saturate the dried peat soils. Given the great age of many fen drainage programs, this is not always an easy or straightforward task. Changes to site and regional hydrology (Okrusczko, 1995, Fisher et al., 1996, Tuittila et al., 1999-2000, Holden et al., 2004, Mälson et al., 2008), peat and 
pore water chemistry (Van Duren, et al., 1998, Jansen et al., 2004), lack of appropriate fill material (Armstrong et al., 2009, Schimelpfenig et al., 2014) and subsidence (Schothorst, 1977, Drexler et al., 2009) can greatly limit the success of a fen restoration project (Komulainen et al., 1999, Pfadenhauer and Grootjans, 1999, Johnson and Valppu, 2003, Van Dijk, 2004, Miller, 2011, Hedberg et al., 2012-2013).

\subsection{Project Overview}

In the Lake Superior Basin, fens have received less attention than elsewhere, especially in regards to restoration (Epstein et al., 1997). What restoration research has been conducted and published has occurred in Minnesota (Johnson and Valppu, 2003). In Michigan, fen restoration has begun in the nearby Seney National Wildlife Refuge (Wilcox et al., 2006, Bork et al., 2013) that drains into northern Lake Michigan. While these research projects focused on headwater and lakeplain fens, there is apparently no published research on the restoration of coastal fens along Lake Superior in northern Michigan.

The goal of this research was to develop management techniques for two relatively common (but often human-impacted) fen types in the southern Lake Superior Basin: lake-side fens and headwater fens. In particular, these projects were undertaken to determine whether seeds could be used to restore these wetland types, as this would ultimately be much more economical than the standard practice of using nursery stock in restoring wetlands. If successful, this technique would also have the advantage of allowing for the use of locally-collected genetic stock for restorations, rather than 
depending on the availability of nursery stock that might derive from genetic pools a considerable distance from the restoration site. Nursery stock taken from more temperate or austral zones might not be well-adapted to weather and soil conditions of more boreal sites such as those along Lake Superior. The efficacy of using biodegradable geotextiles, mulch and organic amendment (i.e. milled peat moss) in facilitating wetland plant germination and establishment in these two fen types was also of interest.

Chapters 2 and 3 focus on restoration efforts at a large, fairly undisturbed headwater fen complex in the eastern Upper Peninsula of Michigan near the town of Newberry (the Sleeper Lake Fen). Specifically, this research focused on firebreak restoration in an area of open fen, the firebreaks resulting from fire-fighting activities associated with a large (>7,250 hectares) wildfire in 2007 . The use of large machinery was tested for replacing disturbed fen peat into the now water-filled firebreaks and the use of mulch, seed and Sphagnum moss diaspores to restore fen vegetation. Pore water sampling and analysis was also included, to determine if various pore water characteristics were associated with differential establishment of plant species in the restored ditch and whether there were any differences in chemistry between the restored and undisturbed fen and if these differences changed over time. Pore water constituents selected for comparison included Dissolved Organic Carbon (DOC), aromatic hydrocarbons, total Nitrogen (TN), pH, Electrical Conductivity, temperature, Al, Ca, Fe, $\mathrm{K}, \mathrm{Mg}, \mathrm{Mn}, \mathrm{P}, \mathrm{Zn}$ and several organic anions.

Vegetation was sampled to compare and contrast between restored and undisturbed fen and pore water chemistry. For the purposes of this study, "undisturbed" 
fen refers to the vegetation and peat next to the ditch that was not excavated during firebreak construction. It is understood that this fen had tracked vehicle traffic along both sides of the ditch during firebreak excavation and restoration (in addition to a recent, hot fire) or had peat spoils covering it for 2 years and therefore is not technically undisturbed. This term is used solely to compare the newly restored and highly disturbed ditch with the unditched fen habitat adjacent to it. Vegetation and pore water sampling in the undisturbed fen was undertaken $\sim 4$ meters away from the edge of the ditch, presumably outside the track width of the bulldozer used for firebreak creation and the excavator used for restoration. The peat surface and vegetation in this zone was visually undistinguishable from adjacent fen further away from the ditch.

Chapter 4 focuses on the creation/restoration of two coastal fens on the shores of Lake Superior along the Keweenaw Peninsula in the western portion of Michigan's Upper Peninsula. Here I tested the use of seeds for coastal wetland restoration in conjunction with natural, biodegradable geotextiles. This research also tested the potential benefit(s) of using organic amendment, in the form of milled peat moss, for establishing wetland vegetation on coastal sites. Vegetation was sampled over a threeyear period to track shifts in species composition and cover over time and under fluctuating lake water levels. 


\subsection{Literature Cited}

Almendinger, J. E. and J. H. Leete. 1998a. Peat characteristics and ground water geochemistry of calcareous fens in the Minnesota River Basin, USA. Biogeochemistry 43:17-41.

Almendinger, J.E., and J.H. Leete. 1998b. Regional and local hydrogeology of calcareous fens in the Minnesota River Basin, USA. Wetlands 18: 184- 202.

Anshaari, G., M. Afifudin, M. Nuriman, E. Gusmayanti, L. Ariane, R. Susana, R. Nusantara, J. Sugardjito, and A. Rafiastanto. 2010. Drainage and land use impacts on changes in selected peat properties and peat degradation in western Kalimantan Province, Indonesia. Biogeosciences 7: 3403-3419.

Amon, J., C. Thompson, Q. Carpenter and J. Miner. 2002. Temperate zone fens of the glaciated Midwest, USA. Wetlands 22(2): 301-317.

Armstrong, A., J. Holden, P. Kay, B. Francis, M. Foulger, S. Gledhill, A. McDonald, and A. Walker. 2010. The impact of peatland drain-sectoring on dissolved organic carbon loss and discolouration of water; results from a national survey. Journal of Hydrology 381(1-2): 112-120.

Armstrong, A., J. Holden, P. Kay, M. Foulger, S. Gledhill A. McDonald and A. Walker. 2009. Drain-blocking techniques on blanket peat: a framework for best practice. Journal of Environmental Management 90:3512-3519.

Bain, C., A. Bonn, R. Stoneman, S. Chapman, A. Coupar, M. Evans, B. Gearey, M. Howat, H. Joosten, C. Keenleyside, J. Labadz, R. Lindsay, N. Littlewood, P. Lunt, C. Miller,n A. Moxey, H. Orr, M. Reed, P. Smith, V. Swales, D. Thompson, 
P. Thompson, R. Van de Noort, J. Wilson and F. Worrall. 2011. IUCN UK Commission of Inquiry on Peatlands. IUCN UK Peatland Programme, Edinburgh.

Bedford, B. and K. Godwin. 2002. Fens of the United States: distribution, characteristics, and scientific connection vs. legal isolation. Wetlands 23:608-629.

Belland, R. and D. Vitt. 1995 Bryophyte vegetation patterns along environmental gradients in continental bogs. Ecoscience 2: 395-407.

Beltman, B., T. van den Broek, K. van Maanen and K. Vaneveld. 1996. Measures to develop a rich-fen wetland landscape with a full range of successional stages. Ecological Engineering 7: 299-313.

Boelter, D.H., and E.S. Verry. 1977. Peatland and water in the northern Lake States. North Central Forest Experiment Station. USDA Forest Service General Technical Report NC-31. 26 pp.

Boomer, K and B. Bedford. 2008. Influence of nested groundwater systems on reduction-oxidation and alkalinity gradients with implications for plant nutrient availability in four New York fens. Journal of Hydrology 351:107-125.

Bork, S., T. Pypker, G. Corace, R. Chimner, A. Maclean and J. Hribljan. 2013. A Case Study in Large-scale Wetland Restoration at Seney National Wildlife Refuge, Upper Michigan, U.S.A. American Midland Naturalist 169:286-302.

Borlick, T. 2013. Caliban and the fen demons of Lincolnshire: the Englishness of Shakespeare's Tempest. Shakespeare 9(1): 21-51. http://dx.doi.org/10.1080/17450918.2012.705882 
Bridgham, S., J. Pastor, J. Janssens, C. Chapin, and T. Malterer. 1996. Multiple limiting gradients in peatlands: A call for a new paradigm. Wetlands 16: 45-65.

Cagampan, J. and J. Waddington. 2008. Moisture dynamics and hydrophysical properties of a transplanted acrotelm on a cutover peatland. Hydrological Processes 22: 1776-1787.

Cobbaert, D, L. Rochefort and J. Price. 2004. Experimental restoration of a fen plant community after peat mining. Applied Vegetation Science 7:209-220.

Cooper, D. and L. MacDonald. 2000. Restoring the vegetation of mined peatlands in the southern Rocky Mountains of Colorado. Ecological Restoration 8(2):103-111.

Crum, H. 1988. A Focus on Peatlands and Peat Mosses. University of Michigan Press. Ann Arbor, Michigan.

Davenport, T., D. Bart and Q. Carpenter. 2014. Altered Plant-community Composition and Edaphic Features Associated with Plowing in Southern Wisconsin Fens. Wetlands 34:449-457.

De Mars, H. and A. Garritsen. 1997. Interrelationship between water quality and groundwater flow dynamics in a small wetland system along a sandy hill ridge. Hydrological Processes 11:335-351.

Drexler, J., C. Fontaine and S. Deverel. 2009. The legacy of wetland drainage on the remaining peat in the Sacramento-San Joaquin delta, California, USA. Wetlands 29(1): 372-386.

Epstein, E., E. Judziewicz and W. Smith. 1997. Wisconsin's Lake Superior Coastal Wetland Evaluation: Including Other Selected Natural Features of the Lake 
Superior Basin. PUB ER-095 99 Wisconsin's Natural Heritage Inventory

Program: Bureau of Endangered Resources, Department of Natural Resources. 325 pages.

Fisher, A., G. Podniesinski and D. Leopold. 1996. Effects of drainage ditches on vegetation patterns in abandoned agricultural peatlands in central New York. Wetlands 16(4): 397-409.

Frey, K. and L. Smith. 2005. Amplified carbon release from vast West Siberian peatlands by 2100. Geophysical Research Letters 32, L09401, doi:10.1029/2004GL022025.

Gignac, L., D. Vitt, S. Zoltai, and S. Bayley. 1991. Bryophyte response surfaces along clmatic, chemical, and physical gradients in peatlands of western Canada. Nova Hedwigia 53: 27-71.

Glaser, P., J. Janssens, and D. Siegel. 1990. The response of vegetation to chemical and hydrological gradients in the Lost River Peatland, northern Minnesota. Journal of Ecology 78: 1021-1048.

Glatzel, S., K. Kalbitz, M. Dalva and T. Moore. 2003. Dissolved organic matter properties and their relationship to carbon dioxide efflux from restored peat bogs. Geoderma113:397-411.

Gorham, E. 1991. Northern Peatlands: Role in the Carbon Cycle and Probable Responses to Climatic Warming. Ecological Applications 1:182-195.

Grootjans, A. and R. van Diggelen. 1995. Assessing the restoration prospects of degraded fens. Pages 73-90 in Wheeler, B., S. Shaw, W. Fojt and R. Robertson, 
editors. Restoration of Temperate Wetlands. J. Wiley and Sins, Ltd., Chichester, United Kingdom.

Hald, A. and E. Vinther. 2000. Restoration of a species-rich fen-meadow after abandonment: response of 64 plant species to management. Applied Vegetation Science 3: 15-24.

Hartig, E., O. Grozev and C. Rosenzweig. 1997. Climate change, agriculture and wetlands in eastern Europe: vulnerability, adaptation and policy. Climatic Change 36: 107-121.

Heathwaite, A. and K. Göttlich. 1993. Mires: Process, Exploitation, and Conservation. Wiley, Chichester.

Hedberg, P., P. Saetre, S. Sundberg, H. Rydin and W. Kotowski. 2013. A functional trait approach to fen restoration analysis. Applied Vegetation Science 16 (2013) $658-666$.

Hedberg, P., W. Kotowski, P. Saetre, K. Mälson, H. Rydin and S. Sundberg. 2012. Vegetation recovery after multiple-site experimental fen restorations. Biological Conservation 147 (2012) 60-67.

Heinselman, M. 1970. Landscape evolution, peatland types, and the environment in the Lake Agassiz Peatlands Natural Area, Minnesota. Ecological Monographs 40: $235-261$.

Holden, J., P. Chapman and J. Labadz. 2004. Artificial drainage of peatlands: hydrological and hydrochemical process and wetland restoration. Progress in Physical Geography 28(1): 95-123. 
Holden, J. 2006. Peatland Hydrology. Pages 319-345 in: Peatlands: evolution and records of environmental and climatic changes. I. Martini, A. Martinez Cortizas and W. Chesworth Ed's. Elsevier.

Holden, J., P. Chapman, S. Lane and C. Brookes. 2006. Impacts of artificial drainage of peatlands on runoff production and water quality. In Martini, I.P., Cortizas, A.M. and Chesworth, W. (editors) Peatlands: basin evolution and depository of records of global environmental and climatic changes, pp. 501-528, Amsterdam, Elsevier

Jansen, A., L. Fresco, A. Grootjans and M. Jalink. 2004. Effects of restoration measures on plant communities of wet heathland ecosystems. Applied Vegetation Science 7:243-252.

Jensen, K. and J. Schrautzer. 1999. Consequences of abandonment for a regional fen flora and mechanisms of successional change. Applied Vegetation Science 2: 7988.

Johnson, K. and S. Valppu. 2003. Fen restoration: Final project report. Report submitted to the Minnesota Department of Natural Resources. 16 pages.

Joosten, H. and D. Clarke. 2002. Wise use of mires and peatlands - Background and principles including a framework for decision-making. International Mire Conservation Group / International Peat Society. 304 pp.

Keddy, P., L. Fraser, A. Solomeshch, W. Junk, D. Campbell, M. Arroyo, C. Alho. 2009. Wet and wonderful: the world's largest wetlands are conservation priorities. Bioscience 59(1): 39-51. 
Kimmel, K. and U. Mander. 2010. Ecosystem services of peatlands: Implications for restoration. Progress in Physical Geography 34(4): 491-514.

Klimkowska, A., R.VanDiggelen, A.Grootjans and W. Kotowski. 2010. Prospects for fen meadow restoration on severely degraded fens. Perspectives in Plant Ecology, Evolution and Systematics 12: 245-255.

Kollmann, J. and K. Rasmussen. 2012. Succession of a degraded bog in northern Denmark over 164 years - monitoring one of the earliest restoration experiments. Tuexenia 32:67-85.

Komulainen, V., E. Tuittila, H. Vasander and J. Laine. 1999. Restoration of drained peatlands in southern Finland: initial effects on vegetation change and $\mathrm{CO} 2$ balance. Journal of Applied Ecology 36: 634-648.

Kremenetski, K., A. Velichko, O. Borisova, G. MacDonald, L. Smith, K. Frey, L. Orlov. 2003. Peatlands of the Western Siberian lowlands: current knowledge on zonation, carbon content and Late Quaternary history. Quaternary Science Reviews 22: 703-723.

Laine, A., M. Leppala, O. Tarvainen,, M. Paatalo, R. Seppanen and A. Tolvnen. 2011. Restoration of managed pine fens: Effects on hydrology and vegetation. Applied Vegetation Science 14:340-349.

Laitinen, J., S. Rehell, and J. Oksanen. 2008. Community and species responses to water level fluctuations with reference to soil layers in different habitats of mid-boreal mire complexes. Plant Ecology 194: 17-36. 
Lamentowicz, M., Ł. Lamentowicz, W. van der Knaap, M. Gąbka and E. Mitchell. 2010. Contrasting Species-Environment Relationships in Communities of Testate Amoebae, Bryophytes and Vascular Plants Along the Fen-Bog Gradient. Microbial Ecology 59:499-510.

Lamers, L., M. Vile, A. Grootjans, M. Acreman, R. van Diggelen, M. Evans, C. Richardson, L. Rochefort, A. Kooijman, J. Roelofs and A. Smolders. 2015. Ecological restoration of rich fens in Europe and North America: from trial and error to an evidence-based approach. Biological Reviews 90: 182-203.

Lamers, L., A. Smolders and J. Roelofs. 2002. The restoration of fens in the Netherlands. Hydrobiologia 478: 107-130.

Locky, D. and S. Bayley. 2006. Plant diversity, composition, and rarity in the southern boreal peatlands of Manitoba, Canada. Canadian Journal of Botany 84: 940-955.

Lode, E. 1999. Wetland restoration: a survey of options for restoring peatlands. Studia Forestalia Suecica no. 205. Swedish University of Agricultural Sciences. Uppsala, Sweden.

Mälson, K, S. Sundberg and H. Rydin. 2009. Peat disturbance, mowing and ditch blocking as tools in rich fen restoration. Restoration Ecology 18(S2):469-478.

Mälson, K., I. Backeus and H. Rydin. 2008. Long-term effects of drainage and initial effects of hydrological restoration on rich fen vegetation. Applied Vegetation Science 11:99-106. 
Maltby, E. and M. Proctor. 1996. Peatlands: their nature and role in the biosphere. In: Global Peat Resources (ed. Lappalainen E), pp. 11-19. International Peat Society, Finland.

McLaughlin, J and K. Webster. 2010. Alkalinity and acidity cycling and fluxes in an intermediate fen peatland in northern Ontario. Biogeochemistry 99(1-3): 143-155.

Middleton, B., B. Holsten and R. van Diggelen. 2006a. Biodiversity management of fens and fen meadows by grazing, cutting and burning. Applied Vegetation Science 9: 307-316.

Middleton, B., A. Grootjans, K. Jensen, H. Olde Venterink and K. Margóczi. 2006 b. Fen Management and Research Perspectives: An Overview. Ecological Studies 191: 247-268.

Miller, C. 2011. The Effects of Long-Term Drainage on Plant Community Composition, Biomass and Productivity in Boreal Continental Peatlands. Master Thesis, University of Guelph, Ontario, Canada.

Motzkin, G. 1994. Calcareous fens of western New England and adjacent New York State. Rhodora 96:44-68.

Mulqueen, J. 1986. Hydrology and drainage of peatland. Environment Geology Water Sciences 9:15-22.

Nekola, J. 2004. Vascular Plant Compositional Gradients within and between Iowa Fens. Journal of Vegetation Science 15(6): 771-780.

Okrusczko, H. 1995. Influence of hydrological differentiation of fens on their transformation after dehydration and on possibilities for restoration. In: 
Restoration of Temperate Wetlands (Ed's: B. Wheeler, S. Shaw, W. Fojt and R. Robertson), pages 112-119. Wiley Inter-Sciences, England.

Parish, F, A. Sirin, D. Charman, H. Joosten, T. Minayeva, M. Silvius and L. Stringer (Eds). 2008. Assessment on Peatlands, Biodiversity and Climate Change: Main Report. Global Environment Center, Kuala Lumpur and Wetlands International, Wageningen.

Pfadenhauer, J. and A. Grootjans. 1999. Wetland restoration in central Europe: aims and methods. Applied Vegetation Science 2: 95-106.

Picking, D. and P. Veneman. 2004. Vegetation patterns in a calcareous sloping fen of southwest Massachusetts. Wetlands 24(3): 514-528.

Poulin, M., L. Rochefort, S. Pellerin and J. Thibault. 2004. Threats and protection for peatlands in Eastern Canada. La Conservation des Tourbières 79(4): 331-344.

Price, J., A. Heathwaite and A. Baird. 2003. Hydrological processes in abandoned and restored peatlands; an overview of management approaches. Wetlands Ecology and Management 11(1-2): 65-83.

Quinty, F. and L. Rochefort. 2003. Peatland Restoration Guide: Second Edition. Canadian Sphagnum Peat Moss Association. 120 pages.

Reeve, A., R. Evensen, P. Glaser, D. Siegel and D. Rosenberry. 2006. Flow path oscillations in transient ground-water simulations of large peatland systems. Journal of Hydrology 316: 313-324. 
Reeve, A., J. Warzocha, P. Glaser, and D. Siegel. 2001. Regional ground-water flow modeling of the Glacial Lake Agassiz Peatlands, Minnesota. Journal of Hydrology 243: 91-100.

Rydin, H. and J. Jeglum. 2006. Biology of Peatlands. Oxford University Press. Oxford England.

Schiff, S., R. Aravena, E. Mewhinney, R. Elgood, B. Warner, P. Dillon, S. Trumbore. 1998. Precambrian shield wetlands: hydrologic control of the sources and export of dissolved organic matter. Climate Change 40: 167-188.

Schimelpfenig, D., D. Cooper and R. Chimner. 2014. Effectiveness of ditch blockage for restoring hydrologic and soil processes in mountain peatlands. Restoration Ecology DOI: 10.1111/rec.12053.

Schothorst, C. 1977. Subsidence of low moor peat in the western Netherlands. Geoderma 17:265-291

Schouwenaars, J. 1988. Hydrological research in disturbed bogs and its role in decisions on water management in the Netherlands. In: Proceedings of international symposium on the hydrology of wetlands in temperate and cold regions (pages 10-177). Joensuu, Finland.

Seer, F. and J. Schrautzer. 2014. Status, future prospects, and management recommendations for alkaline fens in an agricultural landscape: A comprehensive survey. Journal for Nature Conservation 22(4): 358-368.

Seigel, D., A. Reeve, P. Glaser and E. Romanowicz. 1995. Climate-driven flushing of pore water in peatlands. Letters to Nature 374: 531-533. 
Sikes, K., D. Cooper, S. Weis, T. Keeler-Wolf, M. Barbour, D. Ikeda, D. Stout, and J. Evens. 2013. Fen Conservation and Vegetation Assessment in the National Forests of the Sierra Nevada and Adjacent Mountains, California. USDA Forest Service, Pacific Southwest Regional Office.

Sjörs, H. 1950. On the relation between vegetation and electrolytes in north Swedish mire waters. Oikos 2: 241-258.

Sjörs, H. and U. Gunnarsson. 2002. Calcium and pH in north and central Swedish mire waters. Journal of Ecology 90: 650-657.

Slack, N. G., D. H. Vitt, and D. G. Horton. 1980. Vegetation gradients of minerotrophically rich fens in western Alberta. Canadian Journal of Botany $58: 330-350$.

Slaughter, B. and J. Cohen. 2010. Natural community abstract for patterned fen. Michigan Natural Features Inventory, Lansing, MI. 34 pp.

Swanson, D. K. and D. F. Grigal. 1991. Biomass, structure, and trophic environment of peatland vegetation in Minnesota. Wetlands 11:279-302.

Szumigalski, A. and S. Baley. 1997. Net above-ground primary production along a peatland gradient in central Alberta in relation to environmental factors. Ecoscience 4: 385-393.

Thompson, C. A. 1993. Hydrogeology of Iowa Fens. Ph.D. Dissertation. University of Iowa, Iowa City, IA, USA. 
Thormann, M., R. Currah and S. Bayley. 1999. The mycorrhizal status of the dominant vegetation along a peatland gradient in southern boreal Alberta, Canada. Wetlands19: 438-450.

Tuittila, E., V-M. Komulainen, H. Visander and J. Laine. 1999. Restored cut-away peatland as a sink for atmospheric $\mathrm{CO}_{2}$. Oecologia 120:563-574.

Tuittila, E., H. Vasander and J. Laine. 2000. Impact of rewetting on the vegetation of a cut-away peatland. Applied Vegetation Science 3: 205-212.

Turunen, J. 2008. Development of Finnish peatland area and carbon storage 1950-2000. Boreal Environment Research 13: 319-334.

Turunen, J., E. Tomppo, K. Tolonen, and A. Reinikainen. 2002. Estimating carbon accumulation rates of undrained mires in Finland - Application to boreal and subarctic regions. The Holocene 12: 69-80.

van Diggelen, R., B. Middleton, J. Bakker, A. Grootjans and M. Wassen. 2006. Fens and floodplains of the temperate zone: present status, threats, conservation and restoration. Applied Vegetation Science 9: 157-162.

Van Dijk, J., M. Stroetenga, L. Bos, P. Bodegom, H. Verhoef and R. Aerts. 2004. Restoring natural seepage conditions on former agricultural grasslands does not lead to reduction of organic matter decomposition and soil nutrient dynamics. Biogeochemistry 71:317-337.

Van Duren, I., D. Boeye and A. Grootjans. 1997. Nutrient limitations in an extant and drained poor fen: implications for restoration. Plant Ecology 133:91-100. 
van Loon, A., P. Schot, J. Griffioen, M. Bierkens, M. Wassen. 2009. Paleo-hydrological reconstruction of a managed fen area in the Netherlands. Journal of Hydrology 378: 205-217.

Waddington, J., J. Plach, J. Cagampan, M. Lucchese and M. Strack. 2009. Reducing the Carbon Footprint of Canadian Peat Extraction and Restoration. Ambio 38(4): $194-200$.

Wheeler, W. 1897. A History of the Fens of South Lincolnshire, being a description of the Rivers Witham and Welland and their estuary, and an account of the reclamation, drainage and enclosure of the fens adjacent thereto. Second Edition. J. M. Newcomb, Boston and Simpkin, Marshall and Co., London. 680 pages.

Wheeler, B. and K. Giller. 1982. Species richness of herbaceous fen vegetation in Broadland, Norfolk in relation to the quantity of above-ground plant material. Journal of Ecology 70: 179-200.

Whitfield, S., M. Reed, K. Thomson, M. Christie, L. Stringer, C. Quinn, R. Anderson, A. Moxey and K. Hubacek. 2011. Managing peatland ecosystem services: current UK policy and future challenges in a changing world. Scottish Geographical Journal 127(3): 209-230.

Wieder, R. and D. Vitt (Eds). 2006. Boreal Peatland Ecosystems. Springer Ecological Studies 188: Analysis and Synthesis. Springer-Verlag, Berlin-Heidelberg, Germany. 
Wilcox, D., A., R. J. Shedlock, and W. H. Hendrickson. 1986. Hydrology, water chemistry, and ecological relations in the raised mound of Cowles Bog. Journal of Ecology 74:1103-1117.

Wilcox, D., M. Sweat, M. Carlsona and K. Kowalski. 2006. A water-budget approach to restoring a sedge fen affected by diking and ditching. Journal of Hydrology 320: 501-517. 


\section{Chapter 2.0 Ditch Restoration in a Large Northern Michigan Fen: Vegetation Response and Basic Pore water Chemistry ${ }^{1}$}

\subsection{Abstract}

Following a prolonged drought, more than 7,250 ha of a large fen complex in Michigan's Upper Peninsula burned in late summer of 2007. As part of fire-fighting efforts, over $48 \mathrm{~km}$ of bulldozed firebreaks were made in and around the peatland. In 2008, the State of Michigan restored over $32 \mathrm{~km}$ of firebreak in upland areas, but $14.5 \mathrm{~km}$ through the fen proper remained as open-water ditches. In the fall of 2009 , we restored 2 $\mathrm{km}$ of ditch by replacing spoils with an excavator. In addition to ditch filling, we conducted experimental plantings of 18 species of vascular plants and 6 mosses to test the effectiveness of seeding, moss diaspore application and mulching. Surveys during the first and second summers found vigorous re-growth of vegetation both within the treatment quadrats and the controls. Contrary to most published results, the unmulched quadrats had the greatest vegetative cover and richness of plant species, followed by the mulched quadrats and the unplanted controls. By 2011, mean vegetative cover on the treatment quadrats had exceeded the undisturbed ones. Our results indicate that filling is an excellent method of ditch restoration in fens and that seeding increases both plant cover and species richness. Conversely, the addition of moss diaspores and mulch were apparently unnecessary in this case, as moss cover in treatment and control quadrats was similar along the length of the ditch, likely because of the perennially high water table and the presence of living diaspores in the replaced spoils.

1: Bess, J., R. Chimner and L. Kangas. Ditch Restoration in a Large Northern Michigan Fen: Vegetation Response and Basic Pore water Chemistry. Ecological Restoration 32(3): 260-274. ISSN 1522-4740 E-ISSN 1543-4079. 


\subsection{Introduction}

Peatlands are of global importance because of their role in filtering groundwater, providing base flow and nutrients for streams and rivers, as habitat for many unique species and as repositories for carbon (Parish et al., 2008). Although they cover only $3 \%$ of the Earth's surface, peatlands contain $12-30 \%$ or more of terrestrial carbon stocks (Gorham, 1991; Joosten and Cowenberg, 2008) and 10\% of the earth's fresh water (Joosten, 2008). They are also concentrated refugia of biodiversity (Minayeva, 2008; Whitfield et al., 2011). Unfortunately, many peatlands have been altered or destroyed through human activity. Current estimates are that $25 \%$ of the world's peatlands have been destroyed or significantly altered in the past few hundred years (Silvius et al., 2008).

Given their perennially high water table, the only effective way for humans to access and exploit most peatlands has been to drain them. For example, millions of hectares of Scandinavian and Baltic peatland forests have been ditched and drained for timber production (Mälson et al., 2008, Lode, 1999, Mälson et al., 2010, Laine et al., 2011), with more than half of Finland's peat forests drained and converted for timber production (Paavilainen and Paivanen, 1995, Turunen et al., 2002, Turunen, 2008). Many UK, northern European and Russian peatlands have been drained for peat cutting and removal for fuel (Hartig et al, 1997, Bain et al., 2011, Kollmann and Rasmussen, 2012).

In Canada (and the northern US) peatlands are drained to facilitate peat harvesting, with more than 93.7 million cubic meters extracted annually for use in the horticultural trade (Canadian Sphagnum Peat Moss Association, 2012). The tropical 
peatlands of Indonesia and Malaysia are being drained for logging, subsistence agriculture and replacement with biofuel plantations (Silvius et al., 2008, Page et al., 2009, Aanshari et al., 2010, Jauhiainen et al., 2012). Elsewhere in Britain, Europe and the U.S., millions of hectares of temperate fens have been drained for agricultural uses (Fisher et al., 1996, Hartig et al, 1997, Roberts, 1999, Joosten and Clarke 2002, Silvius et al., 2008, Drexler and Deverel, 2009).

Ditches can negatively impact fens in numerous ways. Lowering the water table increases the aerobic portion of the peat strata (the "acrotelm"), leading to an increased decomposition rate and subsidence of the peat (Schothorst, 1977, Okruszko, 1995, Lode, 1999, Holden et al., 2004, 2006a-b, Drexler and Deverel, 2009, Hedberg et al., 2012). Peat subsidence leads to a decrease in soil pore size and hydraulic conductivity, further drying the peatland and leading to changes in vegetative composition (Boelter, 1972, Mulqueen, 1986, Schouwenaars, 1988, Eggelsmann et al., 1993, Fisher et al., 1996, Vasander et al., 1996, Vasander et al., 2003, Miller, 2011; Hedberg et al., 2012). Subsidence also leads to larger fluctuations in groundwater levels, which can increase the amount of organic matter leaving affected peatlands, turning them from net carbon sinks to carbon sources (Schiff et al., 1998, Tuittila et al., 1999, Glatzel et al., 2003, Holden et al., 2004, 2006a-b, Laitinen et al., 2008, Armstrong et al., 2010, McLaughlin and Webster, 2010). Changes in dissolved organic carbon (DOC) can also lead to changes in species and functional groups within the vegetation community of peatlands (Armstrong et al., 2012). 
In fens, drainage ditches can also cut off the flow of mineral-rich groundwater, leading to a reduction in nutrients and an increase in bulk density and acidification of the peat (De Mars et al., 1996, Van Duren et al., 1997, De Mars et al., 1997, Komulainen et al., 1999, Holden et al., 2004, Boomer and Bedford, 2008, Mälson et al., 2008, Hedberg et al., 2012). Dried peat is also very light and friable, making it highly susceptible to wind erosion (Campeau and Rochefort, 1996) and fire (Busque and Arsenault, 2005, Camill et al., 2009, O’Donnell et al., 2009, Ronkainen, 2013).

For projects attempting to restore peatland hydrology, ditches can be actively restored either by filling them entirely or plugging the ends or sectors of ditch with dams (Price, 1996, Tuittila et al., 2000, Howie et al., 2009, Armstrong et al., 2009, Mälson et al., 2010, Ketcheson and Price, 2013, Laine et al., 2011, Bellamy et al., 2012, Hedberg et al., 2012, 2013, Schimelpfenig et al., 2014). Most ditches are plugged because of cost or the oxidation of spoils piles results in a lack of appropriate fill material (Holden et al., 2004). Sometimes there is also concern (often unfounded) that complete filling of the ditch will result in a larger flooded area, negatively affecting adjacent landowners (Hedberg et al., 2012; Holden et al., 2004). Further complicating peatland restoration efforts is the general lack of a viable seed bank in older ( $>10$ years) ditched and excavated sites (Jansen et al., 2004, Graf et al., 2008, Mälson et al, 2010). The perennially saturated soil, fragile vegetation and general inaccessibility of many fens also limit the use of heavy machinery in restoring all but the driest sites. Additionally, very few fen restoration projects have been studied (and reported on) in the Upper Great Lakes 
region (Kowalski and Wilcox, 2003, Johnson and Valppu, 2003, Wilcox et al., 2006, Bork et al., 2013).

Despite these potential difficulties, our goal was to test methods for restoring a newly dug (2 year old) ditch created as part of an extensive fire break system in a large fen in Michigan's Upper Peninsula. Our objectives were to: 1) test the effectiveness of using heavy machinery to replace recently excavated peat back into the ditch, 2) test the effectiveness of experimental plantings of seeds, moss diaspores and mulch, and 3) determine if basic groundwater characteristics ( $\mathrm{pH}$, electrical conductivity) varied along the restored ditch and if this variation was correlated with variation in plant species colonization.

\subsection{Methods}

\subsubsection{Study Site}

Prior to European settlement, Michigan's Upper Peninsula contained approximately 950,000 hectares of peatlands, of which $\sim 185,000$ hectares were open sedge, forb and moss dominated communities (Comer et al., 1995, Slaughter and Cohen, 2010). Among the largest and previously least disturbed peatlands in Michigan is the Sleeper Lake Fen complex (also known as the "Two-Hearted Lowlands") in Luce County (Latitude $46^{\circ} 29^{\prime} 17.17^{\prime \prime N}$, Longitude $85^{\circ} 30^{\prime} 52.96^{\prime \prime W}$ ). The fen complex covers over 20,000 ha and was spared much of the ditching and logging efforts of the late 19th and early 20th centuries that affected other Michigan peatlands. Large sectors of this wetland 
complex are owned by the State of Michigan and The Nature Conservancy, as both State Forest and Nature Preserve, and it is relatively roadless and inaccessible.

Sleeper Lake Fen occupies a former glacial lake plain (glacial Lake Minong) and drainage channel deposited by melt water from the retreating Laurentide ice sheet $\sim 11,400$ cal yrs BP (Loope et al., 2010, Krist and Lusch, 2004). The lakeplain slopes gradually to the southeast and is crisscrossed with low (1-3 m) to tall $(15-20 \mathrm{~m})$ transverse and parabolic dunes vegetated primarily with virgin red, white and jack pine forest and barrens. Several spring-fed lakes are located in the fen proper, the largest being Sleeper and McMahon. The fen complex is also the headwaters of several rivers, including the Augur, Dawson, Two-Hearted and numerous creeks feeding into the Tahquamenon. The local climate is greatly influenced by Lake Superior, with an average annual rainfall of $81 \mathrm{~cm}$ and snowfall of $312 \mathrm{~cm}$ (USFWS, 2009). Annual average temperature is $5.1^{\circ} \mathrm{C}$ (Wilcox et al., 2006) and annual growing season is approximately 119 days (USFWS, 2013). Locally the lakeplain contains two very high quality examples of patterned fen.

The fen caught fire via lightning strike in August of 2007 following a prolonged, La Niña-related drought, ultimately burning more than 7,200 ha over a 3 month period. During the fire, over $48 \mathrm{~km}$ of firebreak were bulldozed in and around the fen complex. Firebreaks in open sedge fen varied from 1-3 $\mathrm{m}$ in width, 1-1.5 $\mathrm{m}$ in depth and 2.6several $\mathrm{km}$ in length. Following the fire, precipitation returned to normal and the water table rose, turning the peatland firebreaks into water-filled ditches, some with appreciable flow. The State of Michigan repaired $\sim 32 \mathrm{~km}$ of the ditch lines throughout much of the 
uplands in 2008 , but $\sim 14-15 \mathrm{~km}$ through the wettest portions had become so saturated that there were concerns machinery would become stuck or cause further damage to the fen vegetation. The Nature Conservancy and State of Michigan asked the authors to develop a plan for restoring these wetland ditches.

\subsubsection{Ditch Filling/Peat Replacement}

A $2.6 \mathrm{~km}$ sector of ditch through grass and sedge-dominated fen (lat. $46^{\circ} 27^{\prime} 13.23^{\prime \prime} \mathrm{N}$ long. $85^{\circ} 28^{\prime} 33.01^{\prime \prime} \mathrm{W}$ ) was chosen for experimental restoration (Figure 2.1). When this $3 \mathrm{~m}$-wide firebreak was initially dug, the peat was curled upside down along one side of the ditch, with vegetation remaining alive along many sectors following the fire. Given the width of the ditch, we decided to use a full-size, 19-ton excavator to replace spoils during the fall of 2009. The excavator operator used timber floats to minimize disturbance of the peat surface and tamped down and "leveled-out" the peat once it was replaced in the ditch. The operator also made a special effort to flip over many of the living peat chunks, so their stratigraphy and microtopography more closely matched that of the undisturbed fen.

\subsubsection{Experimental Design}

Prior to restoration, the undisturbed vegetation along the $2.6 \mathrm{~km}$ ditch was observed to vary markedly in plant species composition and dominance. Therefore, we divided the restoration site into 4 sectors along the ditch (Figure 2.1), with each representing one of four "plant associations" observed in the adjacent, undisturbed fen: 
1. Carex oligosperma-Chamaedaphne calyculata-Betula pumila- Sphagnum spp. Wooded Poor Fen (Plots \#1-5).

2. Andromeda polifolia-Carex magellanica-Iris versicolor-Vaccinium macrocarpon Open Fen (Plots \#6-10);

3. Aster borealis-Carex lasiocarpa-Galium brevipes-Salix spp.-Scutellaria galericulata- Rich Shrub Fen (Plots \#11-15);

4. Doellingeria umbellata-Calamagrostis canadensis-Carex sterilis-Viburnum cassinoides Rich Shrub Fen (Plots \#16-20).

Sectors ranged from $83 \mathrm{~m}$ (Sector 1) to $\sim 400 \mathrm{~m}$ (Sectors 2-4) in length and, within each, we established five replicates of three, 3-meter square experimental planting treatments consisting of: 1) no plant - control, 2) seed only, and 3) seed, moss diaspores and mulch, resulting in a total of 60 research plots. These plots were placed in relatively homogenous areas of restored peat within each Sector. Wholly inundated areas were avoided, as were large clumps of sedge turf and shrub root masses. Plot placement within each set of 3 treatment types was randomly chosen to reduce potential bias.

\subsubsection{Seed and Moss Collection and Planting}

A total of 4 kilograms of seeds were hand collected on-site, from 18 species of wetland plants, for use in the restoration (Table 2.1). Species were selected for collection based on their common occurrence and relative abundance in either the undisturbed, burned fen or the adjacent, unburned fen. Seeds were dried, cleaned, weighed and sorted into individual, identical, $75 \mathrm{~g}$ seed mixes for each seeded plot. The seed mix included 6 
sedges and rushes (Carex magellanica, C. oligosperma, C. utriculata, Dulichium arundinaceum, Eriophorum virginicum and Scirpus atrovirens), 2 grasses (Calamagrostis canadensis and Glyceria canadensis), 6 forbs (Doellingeria umbellata, Iris versicolor, Oclemena nemoralis, Rumex orbiculatus, Solidago uliginosa and Symphiotrichum boreale) and 4 shrubs (Aronia melanocarpa, Betula pumila, Nemopanthus mucronatus and Viburnum nudum cassinoides). Seed mixes were stored in 1 gallon Ziploc ${ }^{\mathrm{TM}}$ bags and kept refrigerated until planting. Immediately prior to use they were placed in a cooler on ice. Individual seed mixes were then chosen randomly from the cooler for spreading onto the 40 research plots to receive seed ( 20 mulch, 20 no mulch). Seed was hand broadcast evenly over each of the $3 \times 3 \mathrm{~m}$ research plots.

We used four species of Sphagnum (S. angustifolium, S. magellanicum, S. papillosum and, S. rubellum) along with Polytrichum commune and P. stricta as our moss component. These were the most common species in adjacent, unburned fen. Mosses were hand collected from the adjacent, unburned portion of the fen and the lower, brown ("dead") portions removed with scissors. The remaining moss was cut into $2.5 \mathrm{~cm}$ sectors (per Campeau and Roquefort, 1996, Roquefort and Lode, 2001, Graf and Roquefort, 2010) and placed in 19-liter plastic buckets. Three buckets were filled with mixed, chopped Sphagnum and one smaller 3.75 liter bucket was filled with freshly chopped Polytrichum spp. We attempted to place an even amount of the four Sphagnum species in each bucket. Polytrichum commune was much more common than P. stricta $(\sim 3: 1)$, and our mix reflected this. 
For each of the 20 seed-moss-mulch plots, a 5.7-liter plastic box was filled with chopped moss at a 10:1 ratio of Sphagnum to Polytrichum by volume. The moss fragments were spread by hand over the entire 3-m square plot (after vascular plant seeds were placed) providing approximately $30 \%$ cover. Moss diaspores were immediately covered with a mulch of dead Calamagrostis canadensis and/or Carex spp. foliage cut into $\sim 45 \mathrm{~cm}$ lengths. Eighteen, 19-liter buckets of mulch were collected on-site and spread over the $20,3 \times 3$ m mulch treatment plots, with a final cover target of

approximately $70 \%$. Following seeding, diaspore planting and mulching, permanent 1-m square "sampling quadrats" of $2.5 \mathrm{~cm}$ diameter PVC tubing were placed in the center of each of the $3 \times 3 \mathrm{~m}$ research plots. This was done to reduce edge effect on our subsequent data collection and analyses.

\subsubsection{Groundwater Monitoring and Pore water Sampling}

Initial groundwater monitoring wells were installed in the center of the restoration area (sector 2), with 1 on each side of ditch to monitor water levels prior to, and following, restoration. Monitoring wells consisted of $1.5-\mathrm{m}$ long sectors of $8 \mathrm{~cm}$ dia. perforated PVC pipe. The outer portion of the perforated pipe was covered with nylon landscaping mesh and secured with zip-ties to prevent sediment from entering the pipe. The bottom of the pipe was covered with a PVC cap to prevent infiltration of peat. Solinst ${ }^{\mathrm{TM}}$ (Georgetown, ON, Canada) Leveloggers were placed in each well, which provided hourly monitoring of the water table. A Solinst ${ }^{\mathrm{TM}}$ (Georgetown, ON, Canada) 
Barologger was also placed in one of the wells to monitor barometric pressure for calibrating the Levelogger data.

Pore water sampling was undertaken to see if observed differences in vegetation along the ditch line correlated with changes in groundwater chemistry ( $\mathrm{pH}$ and electrical conductivity). Sampling was undertaken in November 2010, early May 2011 and late July 2011 to track changes across a growing season. Samples were collected with a 500 $\mathrm{ml}$ syringe attached by Nalgene hosing to a $1.5 \mathrm{~m}$ sector of $0.64 \mathrm{~cm}$ dia. stainless steel tube (similar to a Pushpoint Sampler ${ }^{\mathrm{TM}}$ as described by US EPA (US EPA, 2013)). Every effort was made to minimize disturbance of the peat profile while collecting samples (e.g. minimizing compression of the local peat through standing or walking).

During each sampling event, 60 samples were collected from along the length of the restored ditch: in each Sector, 5 samples from the ditch and 5 each from undisturbed vegetation on each side (total of 15 samples from each of the 4 Sectors). The ditch samples were taken from each of the no mulch research plots and the undisturbed samples were taken at points parallel with the no mulch plots and $\sim 3-4 \mathrm{~m}$ from edge of ditch. All pore water samples were collected with the sipper at $25 \mathrm{~cm}$ beneath the peat surface. Clumps of shrubs and sedge tussocks were avoided, to reduce variability in depth of sample. Prior to gathering each pore water sample, the sipper tube was placed into the sampling location and the syringe filled and purged several times with local water. Samples were taken only after excess organic matter (resulting from sampler insertion into the peat) had been purged from the local collection site and sampler. From each sample, temperature, electrical conductivity and $\mathrm{pH}$ were measured in the field 
using an YSI Model 63 hand-held meter. The $\mathrm{pH}$ meter was calibrated with $\mathrm{pH} 4$ and 7 buffers prior to each sampling event. The sensor was rinsed thoroughly with distilled water between sampling points to minimize potential for cross contamination.

\subsubsection{Vegetation Monitoring and Statistical Analysis}

Vegetation composition and cover data were collected from each of the $60,1-\mathrm{m}$ square ditch research quadrats in August of 2010 and 2011. Data on undisturbed vegetation was collected in August, 2010 from 40 1-m square quadrats (5 on each side of ditch in each sector (10 per sector) placed in undisturbed fen vegetation adjacent to the ditch and parallel to each of the no mulch treatment plots. Data on the undisturbed vegetation was collected only in 2010 , as species composition and cover in these plots was not observed to change greatly over the 2-year period and the thick layer of Carex litter inhibited the growth of any additional seedlings.

For the purposes of this study, "undisturbed" fen refers to the vegetation and peat next to the ditch that was not excavated during firebreak construction. It is understood that this fen had tracked vehicle traffic along both sides of the ditch during firebreak excavation and restoration (in addition to a recent, hot fire) and therefore is not technically undisturbed. This term is used solely to compare the newly restored and highly disturbed ditch with the unditched fen habitat adjacent to it. Vegetation and pore

water sampling in the undisturbed fen was undertaken 3-4 meters away from the edge of the ditch, presumably outside the track width of the bulldozer used for firebreak creation 
and the excavator used for restoration. The peat surface and vegetation in this zone was visually undistinguishable from adjacent fen further away from the ditch.

Plants were identified to species whenever possible, although many vegetative sedges, grasses and young mosses could only be determined to genus. Voss' threevolume "Michigan Flora" (Voss, 1972, 1985, 1996) was used for determinations and the most recent names for our flora were obtained from Voss and Reznicek (2012) and the USDA PLANTS Database (USDA-NRCS, 2012). Vegetative cover was estimated visually by two observers and a consensus was reached for each species to the nearest percentage. Cover was assessed on a per-species or taxon basis and, given the multiple strata of plant growth, total vegetative cover for individual quadrats often exceeded $100 \%$ when values for individual species/taxa were tallied together.

A nested analysis of variance (ANOVA) was used to compare a number of parameters by ditch sector, treatment type (mulched, seeded, control) and undisturbed versus restored peat. Analyzed parameters included total vegetative cover, vascular plant cover, forb cover, grass cover, Cyperaceae cover, bryophyte cover, vascular plant species richness, forb species richness, bare peat and litter. Tukey's Studentized Range Test for comparison of means was run for each of these parameters, comparing mean values among Sectors and treatments, to see which were significantly different from one another. P-values $<0.05$ were considered significant for the ANOVA and Tukey's results. SAS 9.1 software (Proc ANOVA - SAS Institute, Inc., Cary, NC) was used to calculate ANOVAs and Tukey's tests. SigmaPlot (Systat Software, Inc., San Jose, CA) was used to generate regression scatter plots, equations, $\mathrm{R}^{2}$ values and associated $p$ - 
values. For discussion purposes, regression analysis is provided only for the 2011 data as this gave time for vegetation to become established, sedges to grow and become more easy to identify and values should more closely approximate those recorded in the undisturbed fen.

\subsection{Results}

\subsubsection{Depth to Water Table and Pore Water Chemistry}

The depth to water table at the study site varied with seasonal precipitation patterns, with the water table being highest in winter/spring and lowest in mid to late summer (Figure 2.2). In May of 2009, prior to restoration, the east side (down-flow gradient) of the ditch in sector 2 had the slightly higher water table, indicating the ditch might be draining water away from the northern portions of the fen and depositing it in the central portion (sector 2). Additionally, spoils were placed on the up-flow side (west) of the ditch, which may have allowed water from the north to flow south and then out into the east side of sector 2. Flow was also observed in this direction in the ditch prior to restoration. However, following ditch restoration in October of 2009, the depth to water table remained roughly similar to pre-restoration levels and oscillations (Figure 2.2).

Pore water $\mathrm{pH}$ and electrical conductivity increased from the south end of the ditch (Plots 1-5: Sector 1) to the north end (Plots 16-20: Sector 4) (Appendix 2.1; Figure 2.3). Water temperature along the ditch varied over the course of the growing season (Figure 2.3). In May, it increased from south (Sector 1) to north (Sector 4), but in summer the gradient reversed, with temperature decreasing as the ditch approached the 
large transverse dune at the north end of the site, where ground water likely originated (Figure 2.1). November pore water temperatures were similar along much of the ditch (mean temp. in Sectors 1-3 ranged from $6.1-9.0^{\circ} \mathrm{C}$ ), but were somewhat lower at the north end (mean temp. $5.4^{\circ} \mathrm{C}$ in Sector 4). Water temperatures in the adjacent undisturbed fen followed the same trend but were lower than those in the ditch during all three sampling periods (Appendix 2.1).

\subsubsection{Vegetation Results - 2010}

Surveys in 2010 found excellent re-growth of vegetation in the restored ditch, especially within the seeded treatment quadrats and (to a lesser degree) the unplanted controls (Table 2.2, Figure 2.5, Appendix 2.2A-C). In the ditch, the unmulched quadrats had the greatest overall vegetative cover across the 4 sectors (156\%), followed by the mulched (146\%) and controls (126\%). The undisturbed vegetation quadrats adjacent to the ditch had $188 \%$ overall plant cover, averaged across the two sides and 4 sectors (Table 2.2). Among the two treatments and controls, unmulched quadrats had the greatest percent cover of vascular plants (145\%), Cyperaceae (79\%), grasses $(26 \%)$ and forbs (34\%). The control quadrats had the least vascular cover (108\%) and Cyperaceae cover (55\%); the undisturbed fen had the lowest percent cover values for forbs $(25 \%)$ and grasses (15\%) (Figure 5). Analysis of variance testing found significant treatment effects in all parameters except forb and litter cover (Table 2.3).

Mean control (126\%) and undisturbed (188\%) total vegetative cover were significantly different from one another (Figure 2.5). Total vegetative cover averaged 
$143 \%$ along the length of the ditch, across the two experimental treatments and control quadrats. Vascular cover was significantly greater in the undisturbed versus control quadrats (162\% vs $102 \%)$ and Cyperaceae cover greater in the unmulched versus the control quadrats (78\% vs 55\%). Shrub cover (31\%) and Bryophyte cover (43\%) were significantly greater in the undisturbed fen versus the three treatments. Vascular species richness was significantly greater in the seeded treatments (14\%) versus the control $(10 \%)$ quadrats. Litter cover was significantly greater in the undisturbed fen $(60 \%)$ versus the three treatments $(\sim 1 \%$, each) and bare peat provided significantly greater cover in the control (52\%) versus the two seeded treatments (37\% and 35\%, respectively) or the undisturbed fen quadrats (3\%). Total plant species richness was greatest in the mulched and unmulched quadrats ( 47 and 46 species, respectively), followed by the controls ( 42 species) and undisturbed fen (40 species total).

The ditch sectors also varied with respect to plant cover and species richness. Analysis of Variance (ANOVA) of the 2010 data found a strong sector effect across all vegetation parameters except total cover by Cyperaceae (Table 2.3). Looking at just the unmulched quadrats, sector 4 had the greatest overall vegetative cover (194\%), followed by sector $1(151 \%)$, while sectors 2 and 3 had the least (138\% each). The difference in total vegetative cover between sectors 3 and 4 was significant. Mean unmulched vegetative cover across the four sectors was $155 \%$. In sector 4 , vascular plant cover varied from $190 \%$ in the unmulched quadrats to $143 \%$ in the controls. This pattern was repeated in sectors 1 and 3 but the control quadrats had the greatest vascular plant cover (136\%) in sector 2 (Tables 2.2 and 2.3, Appendix 2.2). Mean vascular plant cover was 
$126 \%$ along the length of the ditch, averaged across the three treatments. Grass cover was also much greater in the unmulched quadrats, with sectors $4(56 \%)$ and $3(32 \%)$ having significantly greater cover than sectors $2(10 \%)$ and $1(5 \%)$. Conversely, the unmulched quadrats of sectors 1 and 2 had greater cover by Cyperaceae (101\% and $80 \%$, respectively) than sectors 3 and 4 (62\% and 71\%). Despite these high values, 2010 mean vegetative cover among the two treatment types and control quadrats (143\%) was still less than in undisturbed quadrats adjacent to the ditch (mean cover 180\%).

Bryophyte cover also varied by Sector and treatment. In 2010, total bryophyte cover was greatest in 1ector 1under mulch (61\%) and decreased sharply past the middle of sector 2 , where it had only $16 \%$ cover under mulch. Bryophytes were barely present in sectors 3 and 4, with cover values ranging from only 1-7\% cover. Across the 4 sectors, mulch and moss diaspore addition were marginally beneficial ( $21 \%$ bryophyte cover) versus unmulched (14\%) and control (18\%) quadrats and there were no statistically significant difference among these means. However, in sector 1 (where Sphagnum and Polytrichum did best) bryophyte cover values were much closer between mulched (61\%) and control (53\%) quadrats. ANOVA showed a strong sector*treatment effect for this parameter $(P<0.0001)$ and a strong sector*treatment effect for shrub cover $(P<0.002)$. Total plant species richness in the restored ditch (52 taxa) was much greater than that in the adjacent undisturbed fen (40 taxa) (Appendix 3). 


\subsubsection{Vegetation Results - 2011}

Variation in treatment effects on vegetative parameters observed in 2010 was less apparent in the 2011 data (Table 2.3, Figure 2.5, Appendix 2.2A-C). Overall, total vegetative cover was identical in the mulched and unmulched quadrats $(214 \%$ - averaged among the 4 sectors) and vascular plant cover (181\% and 185\%, respectively), Cyperaceae cover (123\% and $120 \%)$, grass cover (27\% and $32 \%)$ and forb cover (28\% and $29 \%$ ) were statistically indistinguishable. The control quadrats continued to have significantly lower total vegetative cover and lower values for all other vegetative parameters, except for forb cover (33\%), which was slightly greater than that in the mulched, unmulched and undisturbed quadrats ( $28 \%, 29 \%$ and $25 \%$, respectively), but these differences were not statistically significant.

Bryophyte cover across all 4 sectors was only slightly greater in the mulched quadrats (33\%) than the unmulched or controls ( $29 \%$ each), but was still less than in the undisturbed fen quadrats (45\%). None of these differences were statistically significant. Total vegetative cover in the restored ditch was 198\% (averaged across treatments and Sectors), exceeding than in the undisturbed fen (180\%). However, total vegetative cover was still significantly less in the control quadrats $(165 \%)$ than the other two treatments (214\%), but not the undisturbed fen (188\%).

Overall plant species richness was identical between the mulched and unmulched quadrats (45 taxa) and only slightly less in the control quadrats (43 taxa), although composed of different species. Total plant species richness in the ditch (49 taxa), although less than observed in 2010 (52 taxa), still exceeded that of the adjacent, 
undisturbed fen (40 taxa - Appendix 2.3). However, there was significantly greater mean vascular plant and forb species richness in the undisturbed fen quadrats, indicating reduced variance among the undisturbed fen quadrats.

As in 2010, vegetative cover and species richness continued to vary by sector in 2011 (Appendix 2.2A-C). Averaged across the two treatments and controls, sector 1 had the greatest vegetative cover (217\%), followed by 4 (202\%), 2 (191\%) and $3(180 \%)$. Sector 3 had the greatest plant species richness (40 taxa), followed by sectors 4 (36), 2 (23) and 1 (15). Cyperaceae continued to be the dominant plant group (based on cover) in all quadrats, with sectors 1 and 2 having the greatest cover (131\% and $112 \%$, respectively), followed by $3(98 \%)$ and 4 (92\%). Bryophyte cover values continued to be significantly higher (at alpha $=0.05)$ in sectors 1 and 2 (versus sectors 3 and 4$)$ and in sector 1 the average cover values were identical (80\%) among the treatment and control quadrats (Appendix 2.2A-C). Overall plant species richness and distribution varied between sectors, treatments, controls and the undisturbed fen (Appendix 2.3). Fifty seven plant taxa were observed in the ditch quadrats from 2010-2011, while only 40 were observed in the undisturbed fen. A total of 8 plant species were observed in the undisturbed fen that were not seen in the ditch quadrats, while 25 were observed in the ditch quadrats but were absent from the undisturbed fen. All were native wetland plants.

\subsubsection{Vegetation, $\mathrm{pH}$ and Electrical Conductivity}

Total grass cover, forb cover, forb species richness and overall species richness increased with increases in $\mathrm{pH}$ (and electrical conductivity) both years, with the 2011 
data plotted in Figure 2.4. Conversely, bryophyte vegetative cover was inversely related to rises in $\mathrm{pH}$ and electrical conductivity. In only two years following restoration, vegetative parameters in the restored ditch closely approximated those in the adjacent, undisturbed fen (Figures 2.5 and 2.6).

\subsection{Discussion}

Prior to firebreak/ditch creation in 2007, Sleeper Lake Fen was the second largest non-ditched northern fen in the state of Michigan. Invasive species such as purple loosestrife (Lythrum salicaria), reed canary grass (Phalaris arundinacea) and giant reed (Phragmites australis) were absent and even native cattails (Typha latifolia) were rarely observed in the fen complex. This allowed for the development of a rich assortment of native plant diaspora in the underlying peat, as evidenced by the vegetation observed in our control quadrats (Figure 2.5, Appendices 2.2-2.3). Given that our ditch spoils were only two years in age, they likely contained many live seeds, rhizomes and other diaspora, which quickly germinated after re-wetting. Spoils also had little time to decompose and subside, allowing the excavator operator to fill the ditches to a level consistent with adjacent undisturbed fen.

One of the most interesting results of our study was the pore water chemistry and how it related to vegetative cover. The strong temperature gradient along the ditch was indicative of the flow of groundwater from the large, transverse dune complex that formed the north edge of our research site. Water temperature at the north end of the site (in both the ditch and the undisturbed fen) was constant across the growing season and 
always colder than the southern portion of the site during the summer months. Water samples from this region always had higher $\mathrm{pH}$ and electrical conductivity readings than the rest of the site. These factors appear to have a strong influence on the species composition of vegetation in both the restored and the undisturbed fen. The high $\mathrm{pH}$ and electrical conductivity of the pore water had a strong negative influence on bryophyte cover (especially Sphagnum mosses), yet a positive one on cover by grasses and forbs.

The rapid return of vegetative cover and plant species richness to levels approximating those in the adjacent, undisturbed fen (as observed in our study) runs contrary to many other peatland ditch restoration efforts (Van Duren et al., 1997, Tuittila et al., 2000, Cobbaert et al., 2004, Jansen et al., 2004, Van Dijk et al., 2004, Graf et al., 2008, Howie et al., 2009, Mälson et al., 2008, Miller, 2011, Bellamy, 2012). Most of these peatland restoration projects have taken place on previously mined or farmed sites, where little or no seed bank remained and the peat had dried completely, become compacted and/or the surface subsided. In these situations, ditch plugging or filling only rewetted a portion of the former fen and wetland vegetation only grew in close proximity to the former ditches or created pools (Bellamy et al., 2012, Peacock et al., 2012, Komulainen et al., 1999). We believe our results at Sleeper Lake Fen differ because of three factors: 1) the pristine nature of the peatland vegetation and seed bank, 2) the relative youth of the ditch spoils, and 3) a perennially high water table.

In most peatland ditch restoration projects, long periods of time (often $>30$ years) have elapsed between ditch creation and restoration efforts (Schouwenaars, 1988, Okruszko, 1995, Komulainen et al., 1999, Lode, 1999, Cobbaert et al., 2004, Holden et 
al., 2004, Van Dijk et al., 2004, Mälson et al., 2008, Armstrong et al., 2009, Howie et al., 2009, Anshaari et al., 2010, Laine et al., 2011, Hedberg et al., 2012, Schimelpfenig et al., 2014). This time lag has allowed for most ditch spoils to decompose and subside to the point where there is no longer enough organic soil left to fill the ditches completely. This is why most peatland restoration projects have relied on ditch plugging instead of complete filling. Ditch plugging can be an effective method for peatland restoration, but the resulting ditches often remain water-filled for most of the growing season, with vegetation occurring only as a fringe along the saturated edges (Komulainen et al., 1999, Schimelpfenig et al., 2014).

\subsection{Implications for Practice}

A fundamental tenet of peatland restoration has been the need for mulch in establishing vegetation on re-wetted peat soils, especially for re-establishing peat-forming mosses. Previous studies found that the extreme temperature and moisture fluctuations on disturbed peat surfaces required mulch to retain moisture and mediate large temperature fluctuations (Campeau and Rochefort, 1996, Lode, 1999, Rochefort and Lode, 2001, Cobbaert et al., 2004, Jansen et al., 2004, Mälson and Rydin, 2007, Chimner, 2011). In northern latitudes and high altitudes, freeze-thaw cycles typically dislodge young plants before they can become established and mulching helps reduce the effects

of these disturbances (Chimner, 2011). We believe the perennially high water table and rich assortment of living diaspores in the spoils at Sleeper Lake Fen mediated these 
extremes and allowed for the rapid establishment of a thick sod of fen sedges and other plants (Figure 2.6).

Our results indicate this restoration as a whole was successful and that addition of seeds added to both vascular plant cover and species richness. It appears that moss diaspore addition and mulching were only marginally useful in enhancing the growth of Sphagnum or Polytrichum species at this site. The perennially high water table at the site keeps the surface saturated at all times and, in conjunction with a healthy diaspore bank in the peat, likely resulted in the survival and proliferation of Sphagnum mosses in the unmulched and control quadrats, neither of which received moss diaspore applications. By 2011, cover values for Sphagnum mosses were roughly identical among the three treatment types in Sector 1 (see Appendix 2.2). Our study also found mulch to be unnecessary for (and possibly even detrimental to) the germination and establishment of vascular plants. Therefore, in fens having perennially high water tables and relatively young spoils (i.e. $<5$ years in age), mulch addition may not be needed for the establishment of a diverse vegetative cover, saving effort, time and money.

The density of seed application used in this study resulted in an immediate, thick growth of monocots across all treatment quadrats (that were previously bare peat) by summer of 2010. This heavy seeding may have played a role in reducing species richness within the quadrats, particularly shrubs. Many young Aronia, Betula, Nemopanthus and Viburnum seedlings observed in 2010 could not be relocated in 2011 and competition with sedges is thought to be a potential reason for their general exclusion from the local flora. There was also regrowth of some sedge and forb plants surviving in the rewetted 
peat that added to vegetative cover in many quadrats, including controls. Given these observations, a reduction in seed amounts for sedges might be considered for a more diverse plant community. Despite these potential limitations, our treatment quadrats still had species richness values greater than adjacent, undisturbed fen vegetation, across all four sectors, with those in sectors 3 and 4 being nearly 50 percent greater. Overall species richness was also much greater in the restored (57 species) versus the undisturbed (40 species) quadrats, and contained 26 native wetland species not observed in the adjacent undisturbed fen.

Overall, seed, moss diaspore and mulch application were very cost effective for this project, working out to $\$ 90.36$ per each $3 \times 3$ meter restoration plot, including seed/moss/mulch collection, processing, planting, oversight and excavator costs. Total cost was $\$ 8,720.00$. The excavator costs were $\$ 6,000.00$ of this total. Nursery stock would have cost $\sim \$ 1.00 /$ plant and, at a minimum of 144 plants per restoration plot (1 plant every $30 \mathrm{~cm}$ ), would have cost at least $\$ 144.00$ per plot, or $\$ 5,760.00$ for entire experiment, not including delivery charges, labor for planting or excavator expenses. Planting at a quick rate of 120 plants per hour, this would have taken 48 hours to complete. At a minimum pay rate of $\$ 10.00 /$ hour, costs would have been at least $\$ 480.00$.

To approximate the density and diversity of plants that we had with seeding, I would have recommended planting on $15 \mathrm{~cm}$ centers, or 441 plants per $3 \mathrm{~m}^{2}$ restoration plot, for a total cost of $\$ 17,640.00$, just for the restoration plots. Labor would have been an additional $\$ 1,470.00$, minimum. Adding an additional plant in the center of each 15 
cm planting square would result in 765 plants per restoration plot, for a total nursery stock cost of $\$ 30,600.00$. This would have taken a minimum of 255 hours to plant and would have cost at least $\$ 2,550.00$. Several of the species we used in our restoration (e.g. Carex magellanicum, C. oligosperma, Eriophorum virginicum, Oclenema nemoralis and Symphyotrichum boreale) would be nearly impossible to find at a commercial nursery and would have required us to produce our own stock. Seed of these species, which are rarely available, cost $\$ 1,320.00$ to $\$ 4,240.00$ per kilogram or more. Additionally, given the unconsolidated nature of the recently replaced ditch peat, actual planting of nursery stock at this site would have been highly problematic.

\subsection{Acknowledgements}

Funding for this research was provided by The Nature Conservancy, Michigan DNR and the U.S. EPA Great Lakes Restoration Initiative. The Nature Conservancy also provided us with maps, results of previous botanical surveys and on-site lodging. John Hribljan provided invaluable assistance with the collection and preparation of the 20102011 pore water samples and monitoring well placement. Tamara Baker assisted in collecting the 2011 vegetation data, while Jennifer Bush and Erin Grupido helped with the 2011 pore water sampling and data collection. 


\subsection{Literature Cited}

Anshaari, G., M. Afifudin, M. Nuriman, E. Gusmayanti, L Ariane, R. Susana, R. Nusantara, J. Sugardjito and A. Rafiastanto. 2010. Drainage and land use impacts on changes in selected peat properties and peat degradation in western Kalimantan Province, Indonesia. Biogeosciences 7:3403-3419

Armstrong, A., J. Holden, K. Luxton and J. Quinton. 2012. Multi-scale relationship between peatland vegetation type and dissolved organic carbon concentration. Ecological Engineering 47: 182-188.

Armstrong, A., J. Holden, P. Kay, B. Francis, M. Foulger, S. Gledhill, A. McDonald, and A. Walker. 2010. The impact of peatland drain-sectoring on dissolved organic carbon loss and discolouration of water; results from a national survey. Journal of Hydrology 381(1-2): 112-120.

Armstrong, A., J. Holden, P. Kay, M. Foulger, S. Gledhill A. McDonald and A. Walker. 2009. Drain-blocking techniques on blanket peat: a framework for best practice. Journal of Environmental Management 90:3512-3519.

Bain, C., A. Bonn, R. Stoneman, S. Chapman, A. Coupar, M. Evans, B. Gearey, M. Howat, H. Joosten, C. Keenleyside, J. Labadz, R. Lindsay, N. Littlewood, P. Lunt, C. Miller,n A. Moxey, H. Orr, M. Reed, P. Smith, V. Swales, D. Thompson, P. Thompson, R. Van de Noort, J. Wilson and F. Worrall. 2011. IUCN UK Commission of Inquiry on Peatlands. IUCN UK Peatland Programme, Edinburgh. 
Bellamy, P., L. Stephen, I. Maclean and M. Grant. 2012. Response of blanket bog vegetation to drain-blocking. Applied Vegetation Science 15: 129-135.

Boelter, D. 1972. Water table drawdown around an open ditch in organic soils. Journal of Hydrology 15:329-340.

Boomer, K and B. Bedford. 2008. Influence of nested groundwater systems on reduction-oxidation and alkalinity gradients with implications for plant nutrient availability in four New York fens. Journal of Hydrology 351:107-125.

Bork S., T. Pypker R. Corace, R. Chimner, A. Maclean, J. Hribljan. 2013. A case study in large-scale wetland restoration at Seney National Wildlife Refuge, Upper Michigan, USA. The American Midland Naturalist 169:286-302.

Busque, D. and Arsenault, D. 2005. Fire disturbance of larch woodlands in string fens in northern Quebec. Canadian Journal of Botany 83: 599-609.

Camill, P., A. Berry, E. Williams, C. Andreassi, J. Limmer and D. Solick. 2009. Climate-vegetation-fire interactions and their impact on long-term carbon dynamics in a boreal peatland landscape in northern Manitoba, Canada. Journal of Geophysical Research: Biogeosciences 114(G4).

Campeau, S. and L. Rochefort. 1996. Sphagnum regeneration on bare peat surfaces: field and greenhouse experiments. Journal of Applied Ecology 33:599-608. Canadian Sphagnum Peat Moss Association. 2012. International Peat Production (table). http://www.peatmoss.com/pm-harvest.php. 
Chimner, R. 2011. Restoring sedges and mosses into frost heaving iron fens, San Juan Mountains, Colorado. Mires and Peat 8: Art. 7. (Online: http://www.mires-andpeat.net/map08/map 08 07.htm).

Cobbaert, D, L. Rochefort and J. Price. 2004. Experimental restoration of a fen plant community after peat mining. Applied Vegetation Science 7:209-220.

Comer, P., D. Albert, H. Wells, B. Hart, J. Raab, D. Price, D. Kashian, R. Corner, and D. Schuen. 1995. Michigan's native landscape, as interpreted from the General Land Office Surveys 1816-1856. Report to the U.S. E.P.A. Water Division and the Wildlife Division, Michigan Department of Natural Resources. Michigan Natural Features Inventory, Lansing, MI. 76 pp.

De Mars, H. and A. Garritsen. 1997. Interrelationship between water quality and groundwater flow dynamics in a small wetland system along a sandy hill ridge. Hydrological Processes 11:335-351.

De Mars, H., M. Wassen and W. Peeters. 1996. The effect of drainage and management on peat chemistry and nutrient deficiency in the former Jegrzinga-floodplain (NE Poland). Vegetatio 126:59-72

Drexler, J., C. Fontaine and S. Deverel. 2009. The legacy of wetland drainage on the remaining peat in the Sacramento-San Joaquin delta, California, USA. Wetlands 29(1): 372-386.

Eggelsmann, R, A. Heathwaite, G. Grosse-Brauckmann, E. Kuster, W. Nauke, M. Schuch and V. Schweikle. 1993. Physical processes and properties of mires. In: Mires: 
Process, Exploitation and Conservation (Ed's A. Heathwaite and K. Gottlich), pages 171-262. Wiley, England.

Fisher, A., G. Podniesinski and D. Leopold. 1996. Effects of drainage ditches on vegetation patterns in abandoned agricultural peatlands in central New York. Wetlands 16(4): 397-409.

Glatzel, S., K. Kalbitz, M. Dalva and T. Moore. 2003. Dissolved organic matter properties and their relationship to carbon dioxide efflux from restored peat bogs. Geoderma 113:397-411.

Graf, M. and L. Rochefort. 2010. Moss Regeneration for Fen Restoration: Field and Greenhouse Experiments. Restoration Ecology 18(1): 121-130

Graf, M., L. Rochefort and M. Poulin. 2008. Spontaneous revegetation of cutaway peatlands of North America. Wetlands 28(1):28-39.

Gorham, E. 1991. Northern peatlands: role in the carbon cycle and probable responses to climatic warming. Ecological Applications 1:182-195.

Hartig, E., O. Grozev and C. Rosenzweig. 1997. Climate change, agriculture and wetlands in eastern Europe: vulnerability, adaptation and policy. Climatic Change 36: 107-121.

Hedberg, P., P. Saetre, S. Sundberg, H. Rydin and W. Kotowski. 2013. A functional trait approach to fen restoration analysis. Applied Vegetation Science 16 (2013) $658-666$. 
Hedberg, P., W. Kotowski, P. Saetre, K. Mälson, H. Rydin and S. Sundberg. 2012. Vegetation recovery after multiple-site experimental fen restorations. Biological Conservation 147 (2012) 60-67.

Holden, J., P. Chapman and J. Labadz. 2004. Artificial drainage of peatlands: hydrological and hydrochemical process and wetland restoration. Progress in Physical Geography 28(1): 95-123.

Holden, J., M. Evans, T. Burt and M. Horton. 2006a. Impact of land drainage on peatland hydrology. Journal of Environmental Quality 35: 1764-1778.

Holden, J., P. Chapman, S. Lane and C. Brookes. 2006b. Impacts of artificial drainage of peatlands on runoff production and water quality. In Martini, I.P., Cortizas, A.M. and Chesworth, W. (editors) Peatlands: basin evolution and depository of records of global environmental and climatic changes, pp. 501-528, Amsterdam, Elsevier

Howie, S., P. Whitfield, R. Hebda, T. Munson, R. Dakin and J. Jeglum. 2009. Water table and vegetation response to ditch blocking: restoration of a raised bog in southwestern British Columbia. Canadian Water Resources Journal 34(4): 381392.

Jansen, A., L. Fresco, A. Grootjans and M. Jalink. 2004. Effects of restoration measures on plant communities of wet heathland ecosystems. Applied Vegetation Science 7:243-252.

Jauhiainen, J., A. Hooijer and S. Page. 2012. Carbon dioxide emissions from an Acacia plantation on peatland in Sumatra, Indonesia. Biogeosciences 9: 617-630. 
Johnson, K. and S. Valppu. 2003. Fen restoration: Final project report. Report submitted to the Minnesota Department of Natural Resources. 16 pages.

Joosten, H. 2008. What are Peatlands? In: Parish, F, A. Sirin, D. Charman, H. Joosten, T. Minayeva, M. Silvius and L. Stringer (Eds). Assessment on Peatlands, Biodiversity and Climate Change: Main Report. Global Environment Center, Kuala Lumpur and Wetlands International, Wageningen.

Joosten, H. and D. Clarke. 2002. Wise use of mires and peatlands - Background and principles including a framework for decision making. International Mire Conservation Group, International Peat Society, Geifswald.

Joosten, H. and J. Cowenberg. 2008 Peatlands and Carbon. In: Parish, F, A. Sirin, D. Charman, H. Joosten, T. Minayeva, M. Silvius and L. Stringer (Eds). 2008. Assessment on Peatlands, Biodiversity and Climate Change: Main Report. Global Environment Center, Kuala Lumpur and Wetlands International, Wageningen.

Ketcheson, S. and J. Price. 2011. The Impact of Peatland Restoration on the Site Hydrology of an Abandoned Block-Cut Bog. Wetlands 31(6): 1263-1274.

Kollmann, J. and K. Rasmussen. 2012. Succession of a degraded bog in northern Denmark over 164 years - monitoring one of the earliest restoration experiments. Tuexenia 32:67-85.

Komulainen, V., E. Tuittila, H. Vasander and J. Laine. 1999. Restoration of drained peatlands in southern Finland: initial effects on vegetation change and $\mathrm{CO} 2$ balance. Journal of Applied Ecology 36: 634-648. 
Kowalski, K. and D. Wilcox. 2003. Differences in sedge fen vegetation upstream and downstream from a managed impoundment. The American Midland Naturalist 150(2): 199-220.

Krist, F. J. and D. P. Lusch. 2004. Glacial history of Michigan, USA: A regional perspective. Developments in Quaternary Sciences 2:111-117.

Laine, A., M. Leppala, O. Tarvainen,, M. Paatalo, R. Seppanen and A. Tolvnen. 2011. Restoration of managed pine fens: Effects on hydrology and vegetation. Applied Vegetation Science 14:340-349.

Laitinen, J., S. Rehell, and J. Oksanen. 2008. Community and species responses to water level fluctuations with reference to soil layers in different habitats of mid-boreal mire complexes. Plant Ecology 194: 17-36.

Lode, E. 1999. Wetland restoration: a survey of options for restoring peatlands. Studia Forestalia Suecica no. 205. Swedish University of Agricultural Sciences. Uppsala, Sweden.

Loope, H., W. Loope, R. Goble, T. Fisher, H. Jol and J. Seong. 2010. Early Holocene dune activity linked with final destruction of Glacial Lake Minong, eastern Upper Michigan, USA. Quaternary Research 74: 73-81.

Mälson, K, S. Sundberg and H. Rydin. 2010. Peat disturbance, mowing and ditch blocking as tools in rich fen restoration. Restoration Ecology 18(S2):469-478.

Mälson, K., I. Backeus and H. Rydin. 2008. Long-term effects of drainage and initial effects of hydrological restoration on rich fen vegetation. Applied Vegetation Science 11:99-106. 
Mälson, K. and H. Rydin. 2007. The regeneration capabilities of bryophytes for rich fen restoration. Biological Conservation 135: 435-442.

McLaughlin, J and K. Webster. 2010. Alkalinity and acidity cycling and fluxes in an intermediate fen peatland in northern Ontario. Biogeochemistry 99(1-3): 143-155.

Miller, C. 2011. The Effects of Long-Term Drainage on Plant Community Composition, Biomass and Productivity in Boreal Continental Peatlands. Master Thesis, University of Guelph, Ontario, Canada.

Minayeva, T. 2008. Peatlands and Biodiversity. In: Parish, F, A. Sirin, D. Charman, H. Joosten, T. Minayeva, M. Silvius and L. Stringer (Eds). 2008. Assessment on Peatlands, Biodiversity and Climate Change: Main Report. Global Environment Center, Kuala Lumpur and Wetlands International, Wageningen.

Mulqueen, J. 1986. Hydrology and drainage of peatland. Environment Geology Water Sciences 9:15-22.

O’Donnell, J, M. Turetsky, J. Harden, K. Manies, L. Pruett, G. Shetler and J. Neff. 2009. Interactive effects of fire, soil, climate, and moss on CO2 fluxes in black spruce ecosystems of interior Alaska. Ecosystems 12:57-72.

Okrusczko, H. 1995. Influence of hydrological differentiation of fens on their transformation after dehydration and on possibilities for restoration. In: Restoration of Temperate Wetlands (Ed's: B. Wheeler, S. Shaw, W. Fojt and R. Robertson), pages 112-119. Wiley Inter-Sciences, England.

Paavilainen, E. and J. Paivanen. 1995. Peatland Forestry - Ecology and Principles. Springer (Berlin). 
Page, S., A. Hoscilo, H. Wosten, J. Jauhiainen, M. Silvius, J. Rieley, H. Ritzema, K. Tansey, L. Graham, H. Vasander and S. Limin. 2009. Restoration ecology of lowland tropical peatlands in Southeast Asia - Current knowledge and future research directions. Ecosystems 12: 888-905.

Parish, F, A. Sirin, D. Charman, H. Joosten, T. Minayeva, M. Silvius and L. Stringer (Eds). 2008. Assessment on Peatlands, Biodiversity and Climate Change: Main Report. Global Environment Center, Kuala Lumpur and Wetlands International, Wageningen.

Peacock, M., C. Evans, N. Fenner and C. Freeman. 2012. Natural revegetation of bog pools after peatland restoration involving ditch blocking-The influence of pool depth and implications for carbon cycling. Ecological Engineering 57: 297-301.

Price, J. 1996. Hydrology and microclimate of a partly restored cutover bog, Quebec. Hydrological Processes 10:1263-1272.

Roberts, S. 1999. The Kankakee wetlands: a case study in ethics and public policy. Politics and the Life Sciences 18(2):191-200.

Rochefort, L. and E. Lode. 2001. Regeneration potential of different Sphagnum organs removed from the gametophyte in experimental conditions (adapted from Gauthier 2001). Pages 386-387 in: R. Weider and D. Vitt (Eds.) Boreal Peatland Ecosystems. Ecological Studies vol. 188: Analysis and Synthesis. 435 pages.

Ronkainen, T., M. Väliranta and E. Tuittila. 2013. Fire pattern in a drainage-affected boreal bog. Boreal Environment Research 18:309-316 
Schiff, S., R. Aravena, E. Mewhinney, R. Elgood, B. Warner, P. Dillon, S. Trumbore. 1998. Precambrian shield wetlands: hydrologic control of the sources and export of dissolved organic matter. Climate Change 40: 167-188.

Schimelpfenig, D., D. Cooper and R. Chimner. 2014. Effectiveness of ditch blockage for restoring hydrologic and soil processes in mountain peatlands. Restoration Ecology DOI: 10.1111/rec.12053.

Schothorst, C. 1977. Subsidence of low moor peat in the western Netherlands. Geoderma 17:265-291

Schouwenaars, J. 1988. Hydrological research in disturbed bogs and its role in decisions on water management in the Netherlands. In: Proceedings of international symposium on the hydrology of wetlands in temperate and cold regions (pages 10177). Joensuu, Finland.

Silvius, M, H. Joosten and S. Opdam. 2008. Peatlands and People. In: Parish, F, A. Sirin, D. Charman, H. Joosten, T. Minayeva, M. Silvius and L. Stringer (Eds). Assessment on Peatlands, Biodiversity and Climate Change: Main Report. Global Environment Center, Kuala Lumpur and Wetlands International, Wageningen.

Slaughter, B., and J. Cohen. 2010. Natural community abstract for patterned fen. Michigan Natural Features Inventory, Lansing, MI. 34 pp.

Tuittila, E., V-M. Komulainen, H. Visander and J. Laine. 1999. Restored cut-away peatland as a sink for atmospheric $\mathrm{CO}_{2}$. Oecologia 120:563-574. 
Tuittila, E., H. Vasander and J. Laine. 2000. Impact of rewetting on the vegetation of a cut-away peatland. Applied Vegetation Science 3: 205-212.

Turunen, J. 2008. Development of Finnish peatland area and carbon storage 1950-2000. Boreal Environment Research 13: 319-334.

Turunen, J., E. Tomppo, K. Tolonen, and A. Reinikainen. 2002. Estimating carbon accumulation rates of undrained mires in Finland - Application to boreal and subarctic regions. The Holocene 12: 69-80.

USDA, NRCS. 2012. The PLANTS Database (http://plants.usda.gov, 15 August 2012). National Plant Data Team, Greensboro, NC 27401-4901 USA.

US EPA. 2013. Pore Water Sampling. U. S. Environmental Protection Agency: Region 4, Science and Ecosystem Support Division. Athens, GA. http://www.epa.gov/region4/sesd/fbqstp/Pore water-Sampling.pdf

US FWS. 2013. Habitat management Plan for Seney National Wildlife Refuge. 107 pages. http://www.fws.gov/uploadedFiles/SeneyNWR_Habitat\%20Management\%20Pla $\underline{\text { n FINAL_SIGNED.pdf }}$

US FWS. 2009. Comprehensive Conservation Plan for Seney National Wildlife Refuge. 198 pages.

http://www.fws.gov/midwest/planning/seney/FinalCCP/seneyCCP.pdf

Van Dijk, J., M. Stroetenga, L. Bos, P. Bodegom, H. Verhoef and R. Aerts. 2004. Restoring natural seepage conditions on former agricultural grasslands does not 
lead to reduction of organic matter decomposition and soil nutrient dynamics. Biogeochemistry 71:317-337.

Van Duren, I., D. Boeye and A. Grootjans. 1997. Nutrient limitations in an extant and drained poor fen: implications for restoration. Plant Ecology 133: 91-100.

Vasander, H., Tuittila, E.-S., Lode, E., Lundin, L., Ilomets, M., Sallantaus, T., Heikkilä, R., Pitkänen, M. and J. Laine. 2003. Status and restoration of peatlands in northern Europe. Wetlands Ecology and Management 11: 51-63.

Vasander, H., Laiho, R. \& Laine, J. 1996. Changes in species diversity in peatlands drained for forestry. In: Trettin, C.C., Jurgenson, M., Grigal, D., Gale, M. \& Jeglum, J. (eds.), Northern Forested Wetlands: Ecology and Management: 109119. CRC Lewis Publishers.

Voss, E. 1996. Michigan Flora: Dicots (Pyrolaceae-Compositae). Cranbrook Institute of Science.

Voss, E. 1985. Michigan Flora: Dicots (Saururaceae-Cornaceae). Cranbrook Institute of Science.

Voss, E. 1972. Michigan Flora: Gymnosperms and monocots. Cranbrook Institute of Science.

Voss, E. and A. Reznicek. 2012. Field Manual of Michigan Flora. The University of Michigan Press, Ann Arbor, Michigan. 990 pages.

Whitfield, S., M. Reed, K. Thomson, M. Christie, L. Stringer, C. Quinn, R. Anderson, A. Moxey and K. Hubacek. 2011. Managing peatland ecosystem services: current 
UK policy and future challenges in a changing world. Scottish Geographical Journal 127(3): 209-230.

Wilcox, D, M. Sweat, M. Carlson and K. Kowalski. 2006. A water budget approach to restoring a sedge fen affected by ditching and diking. Journal of Hydrology $320: 501-517$. 


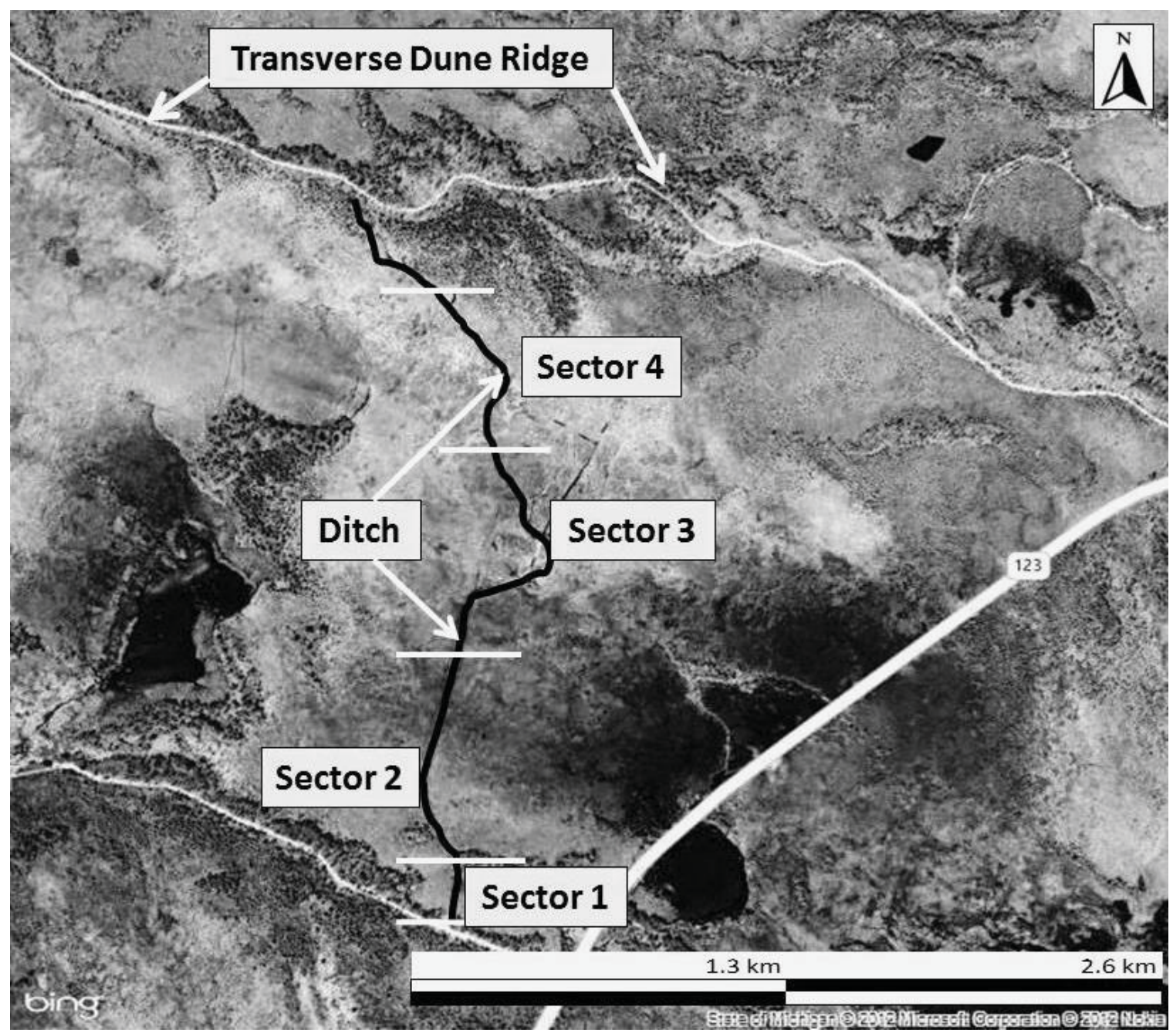

Figure 2.1. Aerial view of the Sleeper Lake Fen restoration site showing the ditch, sectors 1-4 and transverse dune ridge. Source: "Sleeper Lake Fen." Bing Maps, Microsoft, Inc. Accessed September 20, 2012. 


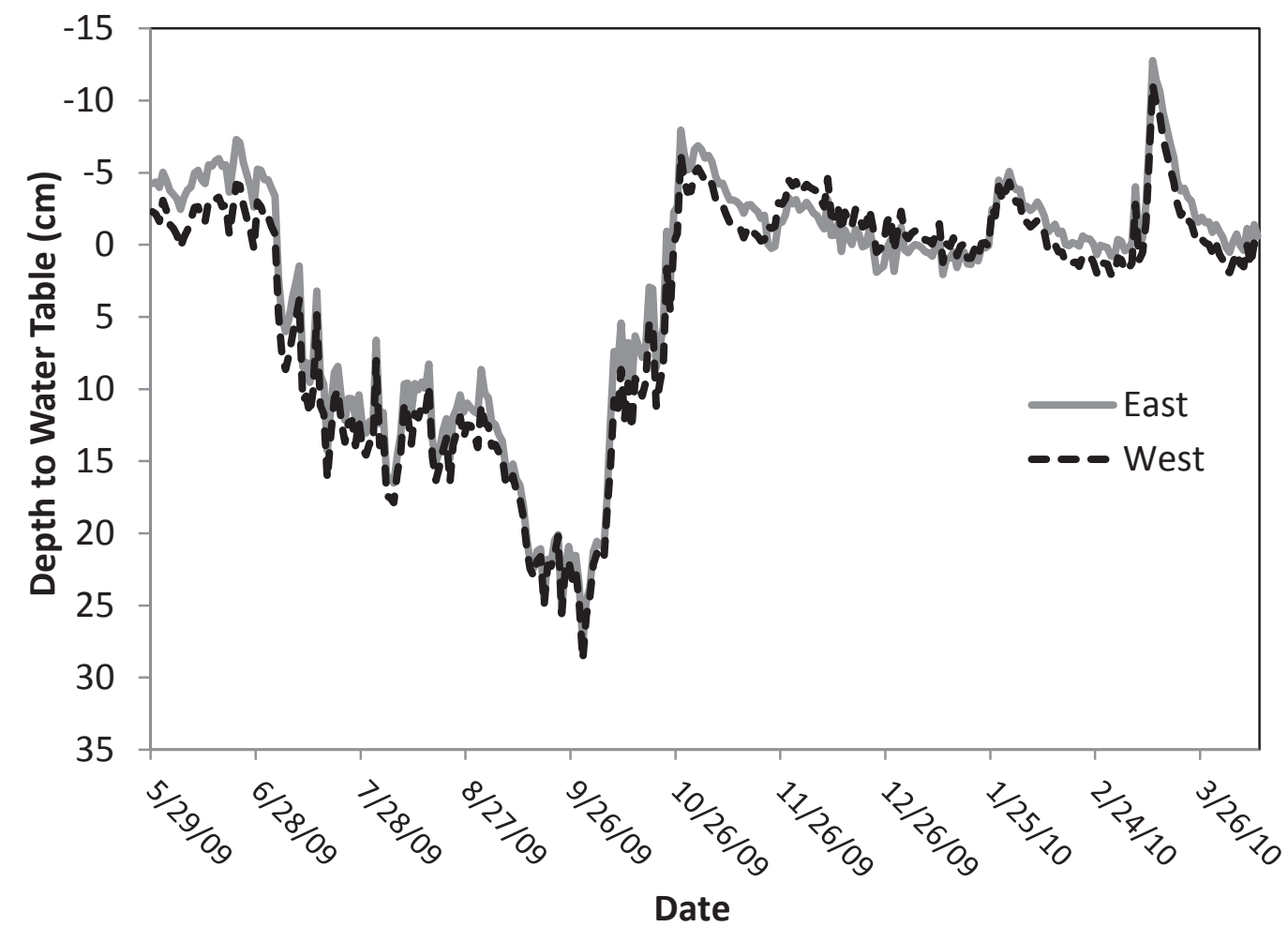

Figure 2.2. Water table levels before and after ditch restoration (2009-2010) at the Sleeper Lake Fen site. The ditch was filled in late October, 2009. $[0=$ peat surface and negative values are the water table above peat surface.] 

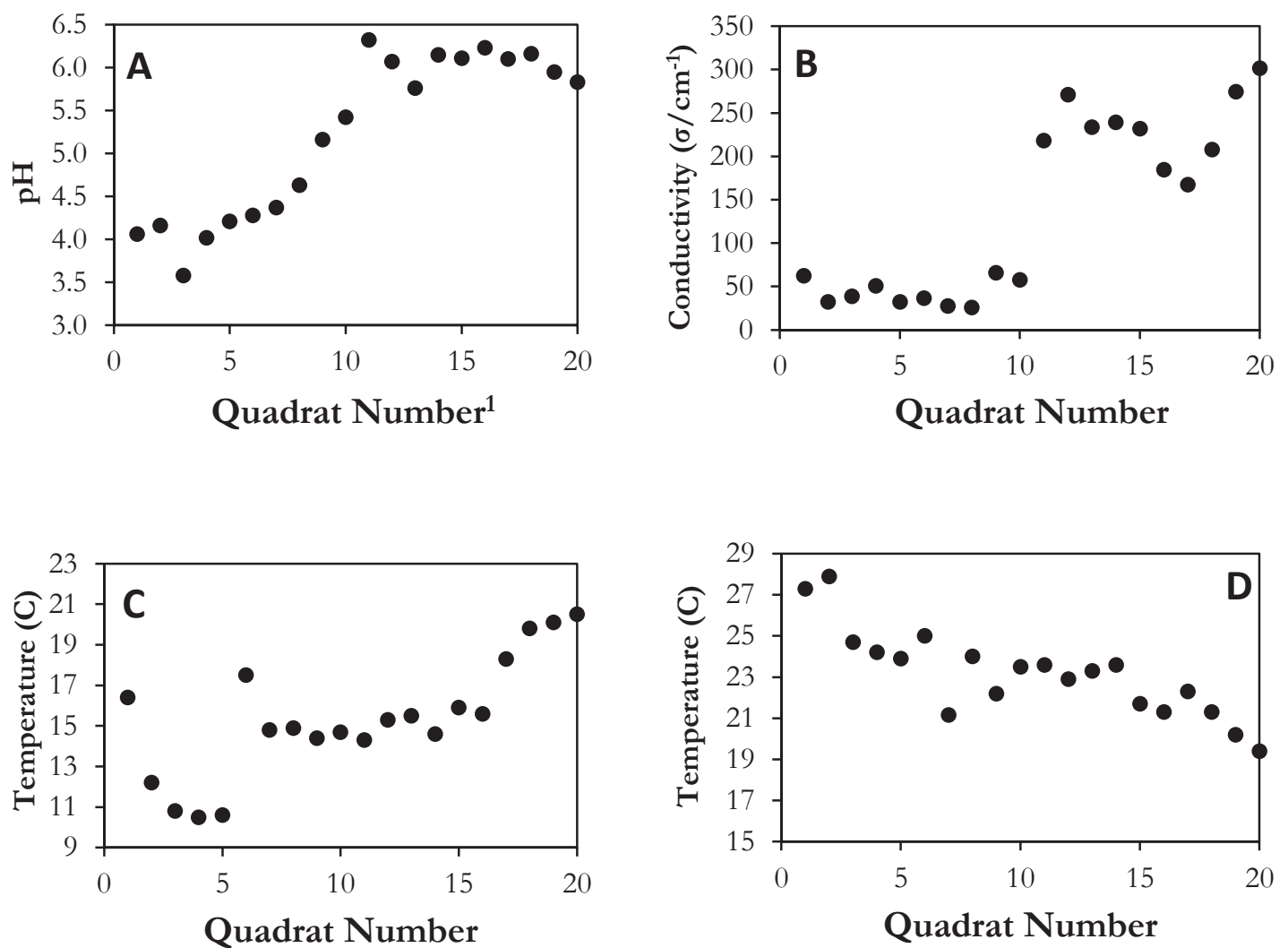

Figure 2.3. Variation in $\mathrm{pH}$, electrical conductivity and temperature along the ditch (2011 data) at the Sleeper Lake Fen restoration site. A.) pH by quadrat number; B.) Electrical conductivity by quadrat number; C.) Spring temperature by quadrat number; D.) Summer temperature by quadrat number.

1: Quadrats \#1-5 = Sector 1 (south end of ditch), \#6-10 = Sector 2, \#11-15 = Sector 3, \#16-20 = Sector 4 (north end of ditch). 

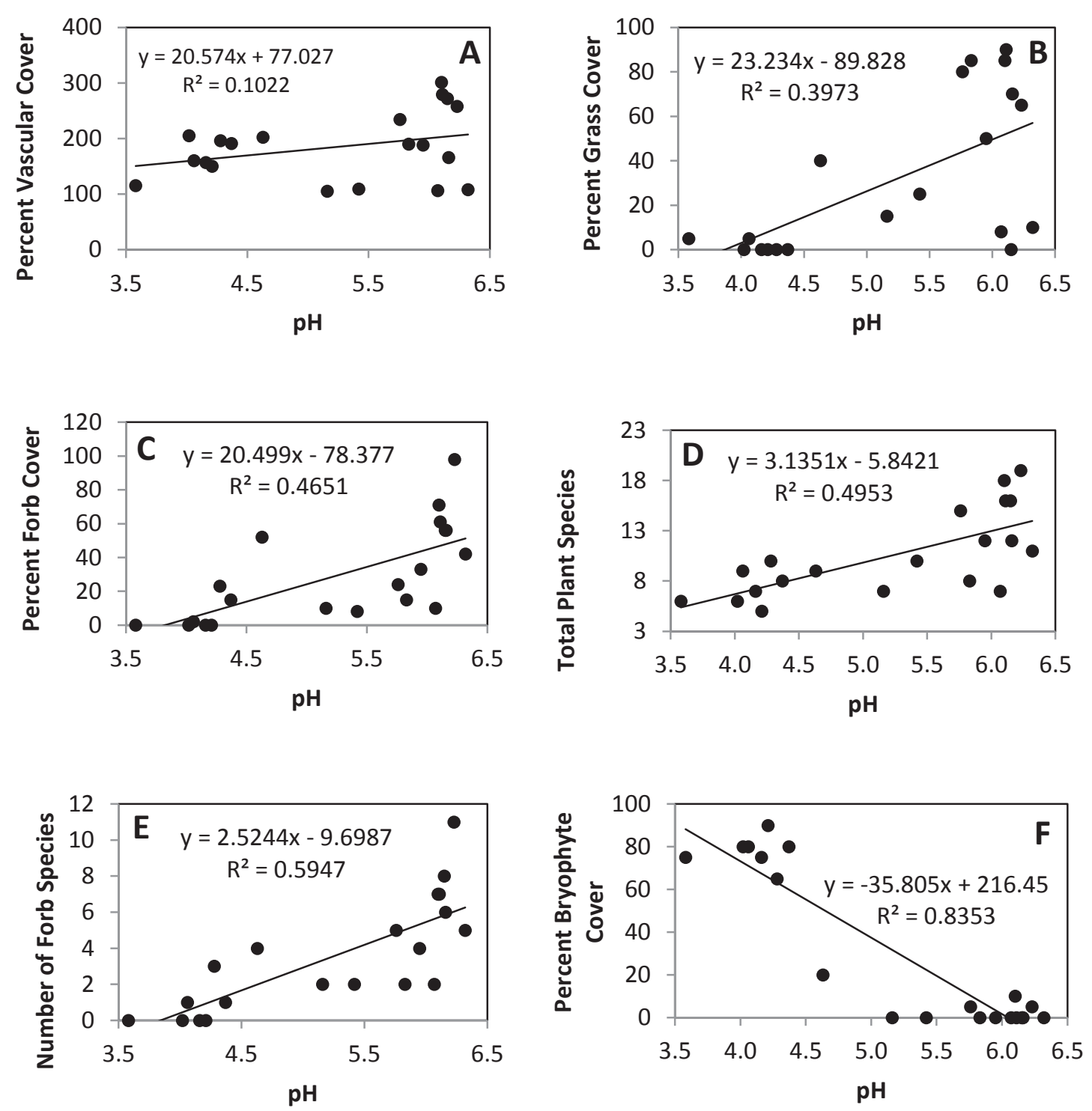

Figure 2.4. Regression analysis of $\mathrm{pH}$ versus various vegetation cover classes in the restored ditch (2011 No Mulch data) at the Sleeper Lake Fen site. A.) pH vs vascular species cover $(p$-value $=0.169), \mathrm{B}.) \mathrm{pH}$ vs grass cover $(p$-value $=$ $0.003), \mathrm{C}$. $) \mathrm{pH}$ vs forb cover $(p$-value $=0.007)$, D. $) \mathrm{pH}$ vs overall plant species richness $(p$-value $=0.001), \mathrm{E}$.) $\mathrm{pH}$ vs forb species richness ( $p$-value $<0.001)$, F.) $\mathrm{pH}$ vs Bryophyte cover ( $p$-value $<0.001)$. 

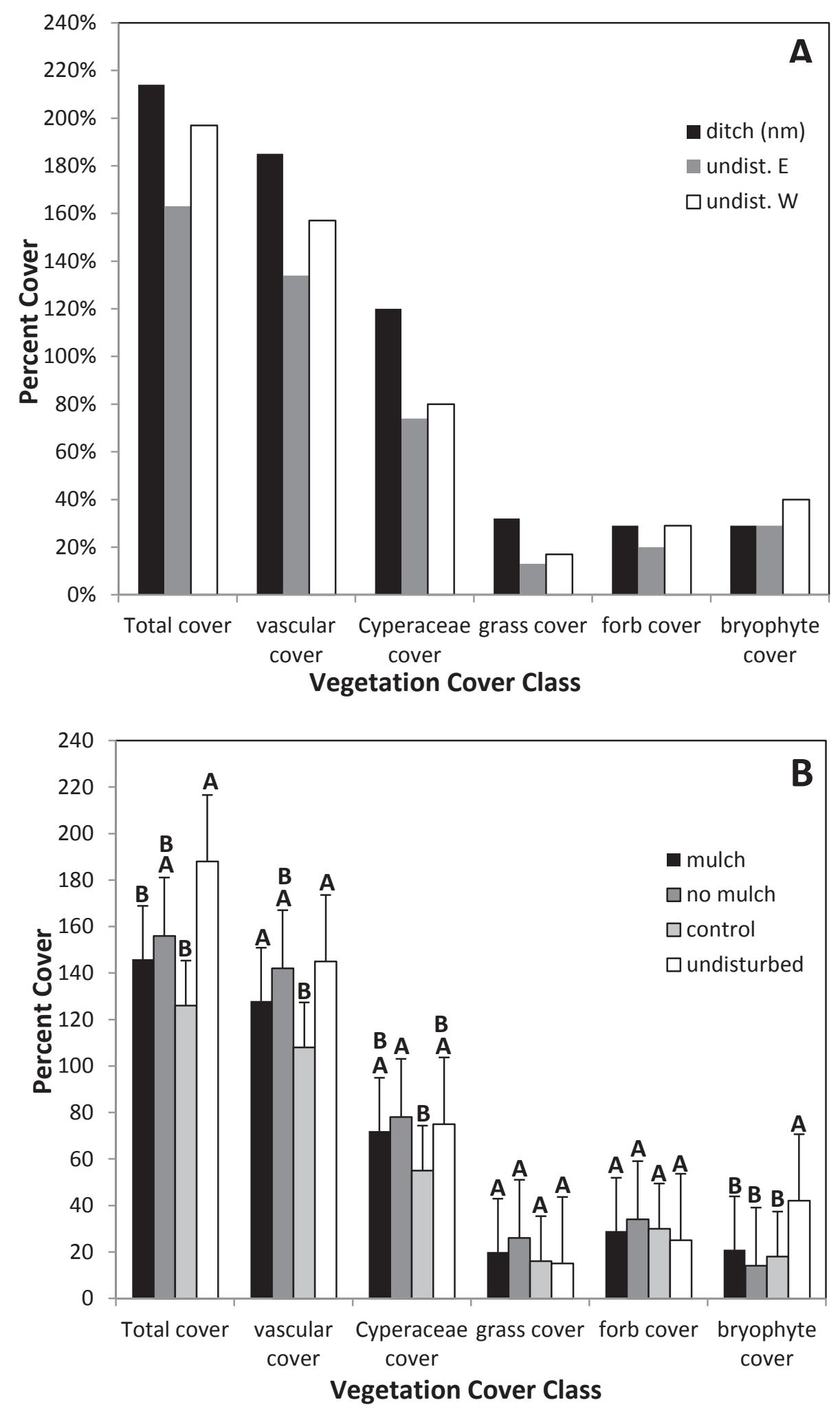


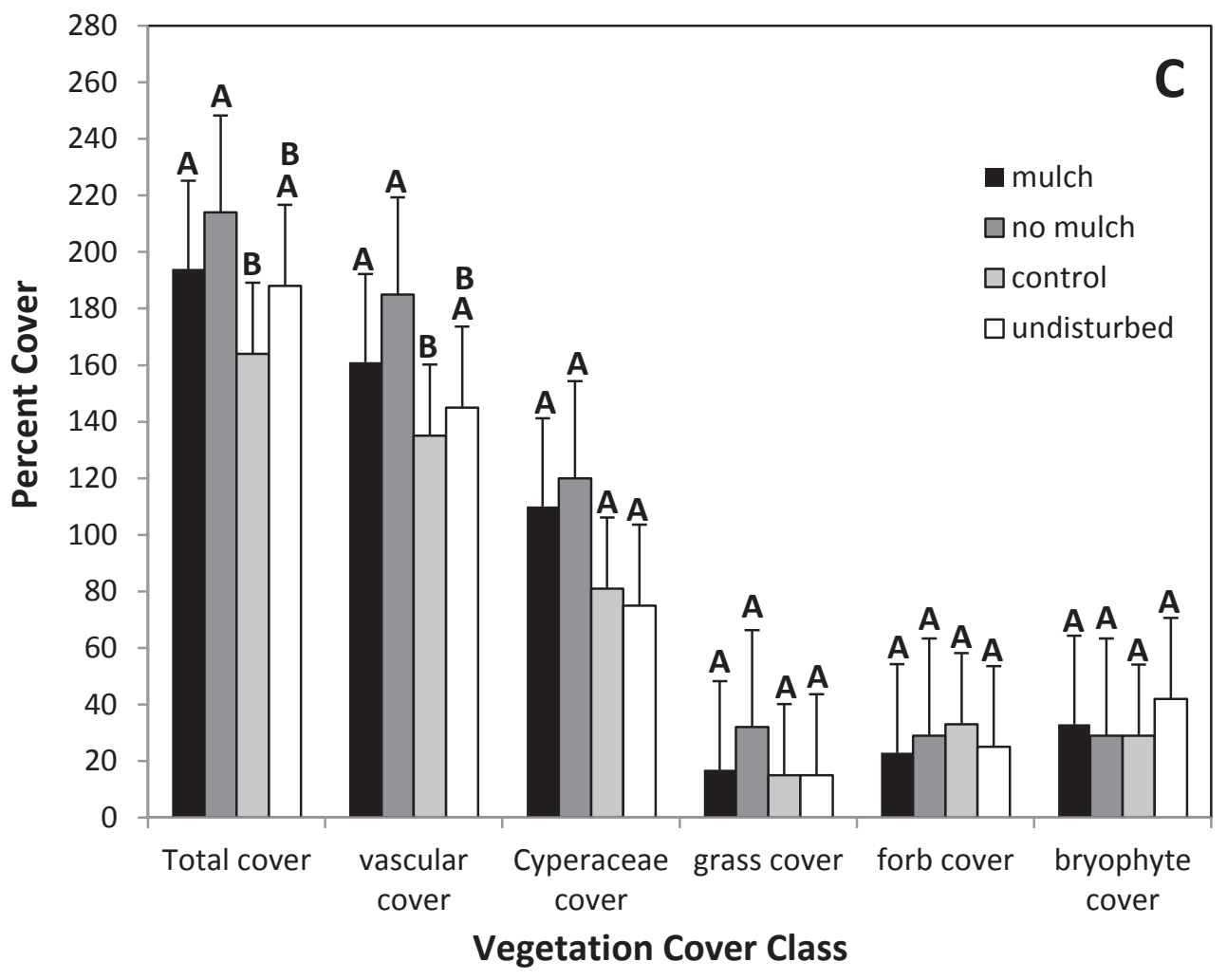

Figure 2.5A-C. Mean (se) values for vegetative cover classes at the Sleeper Lake Fen restoration site. A.) 2011 ditch no mulch $(\mathrm{nm})$ treatment vs undisturbed fen on $\mathrm{E}$ and $\mathrm{W}$ side of ditch, showing similarity of values for various vegetative parameters B.) 2010 ditch treatments and controls vs undisturbed fen, and C.) 2011 ditch treatments and controls vs undisturbed fen. Cover values are averages across the four sectors. Undisturbed $\mathrm{E}$ and $\mathrm{W}$ values are averages from the quadrats in undisturbed fen on each side of the restored ditch. In 5B and 5C, letters above means represent results of Tukey's tests - means sharing the same letter are not statistically different at alpha $=0.05$. 

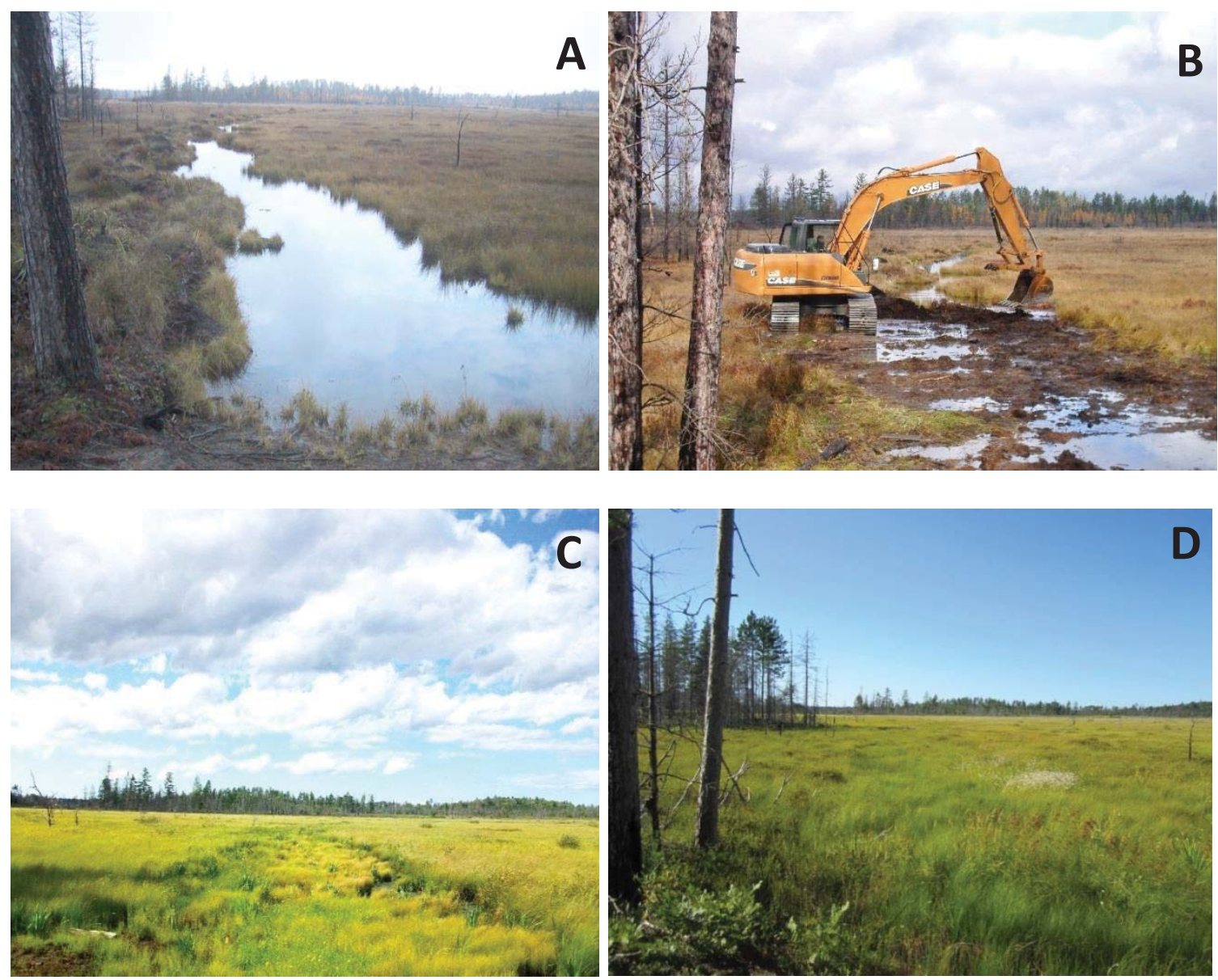

Figure 2.6. Photographic time sequence of ditch restoration 2009-2011 at the Sleeper Lake Fen site. Photographs from top of dune between Sectors 1 and 2, view to northwest into sector 2: note tree line in central background as reference point. A.) Ditch prior to restoration (2009); B.) Ditch immediately following restoration (2009): C.) Ditch vegetation after 1 year growth (2010): D.) Ditch vegetation after 2 years growth (2011 - white patch in right center of photo is Eriophorum virginicum growing in restoration plots 6A-B). 
Table 2.1. Plant species and seed amounts used (grams per $3-\mathrm{m}^{2}$ research plot) in the Sleeper Lake Fen restoration site.

\begin{tabular}{|c|c|c|}
\hline Scientific Name & Common Name & $\begin{array}{c}\text { Seed per } 3 \mathrm{~m}^{2} \text { Plot } \\
(\mathrm{g})\end{array}$ \\
\hline \multicolumn{3}{|l|}{ Shrubs } \\
\hline Aronia melanocarpa & Chokeberry & 3.0 \\
\hline Betula pumila & Bog Birch & 1.3 \\
\hline Nemopanthus mucronatus & Winterberry & 0.5 \\
\hline Viburnum nudum cassinoides & Withe Rod & 5.6 \\
\hline \multicolumn{3}{|l|}{ Forbs } \\
\hline Doellingeria umbellata & Flat-Topped White Aster & 2.2 \\
\hline Iris versicolor & Northern Blue Flag & 20.0 \\
\hline Oclemena nemoralis & Bog Aster & 0.4 \\
\hline Rumex orbiculatus & Greater Water Dock & 0.7 \\
\hline Solidago uliginosa & Bog Goldenrod & 0.7 \\
\hline Symphiotrichum boreale & Northetrn Bog Aster & 0.2 \\
\hline \multicolumn{3}{|l|}{ Grasses, Rushes and Sedges } \\
\hline Calamagrostis canadensis & Canada Bluejoint & 5.3 \\
\hline Carex magellanica & Boreal Bog Sedge & 14.0 \\
\hline Carex oligosperma & Fewseed Sedge & 8.8 \\
\hline Carex utriculata & Northwest Territory Sedge & 1.0 \\
\hline Dulichium arundinaceum & Three-Square Sedge & 2.2 \\
\hline Eriophorum virginicum & Tawny Cottongrass & 4.7 \\
\hline Glyceria canadensis & Rattlesnake Manna Grass & 2.7 \\
\hline Scirpus atrovirens & Dark Green Bulrush & 2.0 \\
\hline \multicolumn{3}{|l|}{ Mosses } \\
\hline Polytrichum commune & Common Haircap Moss & $0.05 \mathrm{~L}$ \\
\hline Polytrichum strictum & Narrow Haircap Moss & $0.05 \mathrm{~L}$ \\
\hline Sphagnum angustifolium & Narrowleaf Peatmoss & $1.4 \mathrm{~L}$ \\
\hline Sphagnum magellanicum & Magellan's Peatmoss & $1.4 \mathrm{~L}$ \\
\hline Sphagnum papillosum & Papillose Peatmoss & $1.4 \mathrm{~L}$ \\
\hline \multirow[t]{3}{*}{ Sphagnum rubellum } & Red Peatmoss & $1.4 \mathrm{~L}$ \\
\hline & Total Grams Seed per Plot: & 75.3 \\
\hline & Total Moss per Plot: & $5.7 \mathrm{~L}$ \\
\hline
\end{tabular}


Table 2.2. Percent cover values for vegetation classes in restored ditch (no mulch) vs undisturbed fen in 2010 at the Sleeper Lake Fen restoration site.

\begin{tabular}{|c|c|c|c|c|c|c|c|c|c|c|}
\hline \multirow{3}{*}{$\begin{array}{r}\text { Date } \\
\text { Plot Type } \\
\text { Sector }\end{array}$} & \multicolumn{10}{|c|}{$\begin{array}{c}\text { August, } 2010 \\
\text { Restored - No Mulch }\end{array}$} \\
\hline & \multicolumn{2}{|c|}{1} & \multicolumn{2}{|c|}{2} & \multicolumn{2}{|c|}{3} & \multicolumn{2}{|c|}{4} & \multicolumn{2}{|c|}{$\begin{array}{l}\text { Ditch } \\
\text { Total }\end{array}$} \\
\hline & $\mathbf{x}$ & $S D^{1}$ & $\mathbf{x}$ & SD & $\mathbf{x}$ & SD & $\mathbf{x}$ & SD & $\mathbf{x}$ & SD \\
\hline Total Vegetation & 151 & 32 & 138 & 39 & 144 & 83 & 186 & 44 & 155 & 53 \\
\hline Vascular & 111 & 32 & 161 & 33 & 137 & 81 & 180 & 38 & 147 & 54 \\
\hline Cyperaceae & 101 & 34 & 118 & 42 & 62 & 33 & 62 & 17 & 86 & 32 \\
\hline Grasses & 5 & 0.4 & 9 & 9 & 32 & 32 & 56 & 29 & 26 & 28 \\
\hline Forbs & 3 & 2 & 33 & 18 & 38 & 22 & 48 & 28 & 31 & 26 \\
\hline Bryophytes & 40 & 17 & 16 & 8 & 2 & 2 & 6 & 8 & 16 & 18 \\
\hline Shrubs & 1 & 1 & 0.4 & 3 & 4 & 5 & 6 & 6 & 3 & 4 \\
\hline Bare Peat & 33 & 12 & 43 & 23 & 45 & 28 & 16 & 1 & 34 & 21 \\
\hline Open Water & 0 & 0 & 0 & 0 & 0 & 0 & 0 & 0 & 0 & 0 \\
\hline Litter & 0 & 0 & 0 & 0 & 5 & 8 & 0 & 0 & 1 & 4 \\
\hline
\end{tabular}

\begin{tabular}{|c|c|c|c|c|c|c|c|c|c|c|}
\hline \multirow{3}{*}{$\begin{array}{r}\text { Date } \\
\text { Plot Type } \\
\text { Sector }\end{array}$} & \multicolumn{10}{|c|}{$\begin{array}{c}\text { August, } 2010 \\
\text { Undisturbed (2010 data) }\end{array}$} \\
\hline & \multicolumn{2}{|c|}{1} & \multicolumn{2}{|c|}{2} & \multicolumn{2}{|c|}{3} & \multicolumn{2}{|c|}{4} & \multicolumn{2}{|c|}{$\begin{array}{l}\text { Ditch } \\
\text { Total }\end{array}$} \\
\hline & $\mathbf{X}$ & SD & $\mathbf{x}$ & SD & $\mathbf{x}$ & SD & $\mathbf{x}$ & SD & $\mathbf{x}$ & SD \\
\hline Total Vegetation & 210 & 28 & 222 & 24 & 164 & 13 & 154 & 16 & 188 & 34 \\
\hline Vascular & 127 & 30 & 147 & 19 & 157 & 17 & 149 & 16 & 145 & 22 \\
\hline Cyperaceae & 71 & 13 & 76 & 14 & 80 & 17 & 72 & 15 & 75 & 14 \\
\hline Grasses & 0 & 0 & 11 & 11 & 16 & 15 & 33 & 21 & 15 & 17 \\
\hline Forbs & 1 & 2 & 26 & 6 & 46 & 12 & 26 & 6 & 25 & 17 \\
\hline Bryophytes & 83 & 10 & 75 & 16 & 7 & 5 & 6 & 5 & 42 & 38 \\
\hline Shrubs & 55 & 31 & 34 & 15 & 15 & 13 & 18 & 14 & 31 & 24 \\
\hline Bare Peat & 0 & 0 & 0 & 0 & 12 & 10 & 2 & 4 & 3 & 7 \\
\hline Open Water & 0 & 0 & 0 & 0 & 12 & 10 & 2 & 4 & 3 & 7 \\
\hline Litter & 60 & 8 & 68 & 9 & 42 & 16 & 69 & 12 & 60 & 15 \\
\hline
\end{tabular}

1: SD = Standard Deviation

2: Undisturbed vegetation values are averages of values taken from undisturbed fen on the east and west sides of the ditch. 
Table 2.3. ANOVA results for independent t-tests on each of the vegetation cover classes - mean vegetation parameters by sector and treatment type vs undisturbed vegetation (2010-2011) at the Sleeper Lake Fen restoration site.

\begin{tabular}{|c|c|c|c|c|c|c|c|}
\hline \multirow[b]{2}{*}{$\begin{array}{l}\text { Restoration } \\
\text { Parameter }\end{array}$} & \multicolumn{7}{|c|}{2010} \\
\hline & $\begin{array}{l}\text { Root } \\
\text { MSE }\end{array}$ & $\begin{array}{c}\text { y1^ } \\
\text { Mean }\end{array}$ & $\begin{array}{c}\text { y1 } \\
\text { P- } \\
\text { value }\end{array}$ & $\begin{array}{c}\text { R- } \\
\text { Square }\end{array}$ & $\begin{array}{c}\text { Sector } \\
\text { P-val }\end{array}$ & $\begin{array}{l}\text { Treat } \\
\text { P-val }\end{array}$ & $\begin{array}{c}\text { Treat } \mid \text { Sector } \\
\text { P-val }\end{array}$ \\
\hline Vegetative Cover & 43 & 154 & $.0007^{*}$ & 0.43 & $.027^{*}$ & $.0003^{*}$ & 0.093 \\
\hline Vascular Cover & 41 & 131 & $.0031^{*}$ & 0.39 & $.0003^{*}$ & $.026^{*}$ & 0.430 \\
\hline Cyperaceae Cover & 27 & 70 & 0.196 & 0.24 & 0.208 & $.043^{*}$ & 0.632 \\
\hline Grass Cover & 19 & 19 & $<.0001^{*}$ & 0.51 & $<.0001^{*}$ & $.028 *$ & 0.946 \\
\hline Forb Cover & 15 & 29 & $<.0001^{*}$ & 0.64 & $<.0001^{*}$ & 0.33 & $.048^{*}$ \\
\hline Shrub Cover & 12 & 11 & $<.0001^{*}$ & 0.64 & $.036 *$ & $<.0001^{*}$ & $.002 *$ \\
\hline Bryophyte Cover & 11 & 24 & $<.0001^{*}$ & 0.89 & $<.0001^{*}$ & $<.0001^{*}$ & $<.0001^{*}$ \\
\hline Vascular Diversity & 3 & 13 & $<.0001^{*}$ & 0.68 & $<.0001^{*}$ & $.001 *$ & 0.104 \\
\hline Forb Diversity & 2 & 5 & $<.0001^{*}$ & 0.64 & $<.0001^{*}$ & $.030 *$ & 0.149 \\
\hline Bare Peat & 17 & 32 & $<.0001^{*}$ & 0.66 & $<.0001^{*}$ & $<.0001^{*}$ & 0.378 \\
\hline \multirow[t]{2}{*}{ Litter } & 7 & 16 & $<.0001 *$ & 0.95 & 0.86 & 0.46 & $<.0001^{*}$ \\
\hline & \multicolumn{7}{|c|}{2011} \\
\hline $\begin{array}{c}\text { Restoration } \\
\text { Parameter }\end{array}$ & $\begin{array}{l}\text { Root } \\
\text { MSE }\end{array}$ & $\begin{array}{c}\text { y1^ } \\
\text { Mean }\end{array}$ & $\begin{array}{c}\text { y1 } \\
\text { P- } \\
\text { value }\end{array}$ & $\begin{array}{c}\text { R- } \\
\text { Square }\end{array}$ & $\begin{array}{l}\text { Sector } \\
\text { P-val }\end{array}$ & $\begin{array}{l}\text { Treat } \\
\text { P-val }\end{array}$ & $\begin{array}{c}\text { Treat } \mid \text { Sector } \\
\text { P-val }\end{array}$ \\
\hline Vegetative Cover & 53 & 194 & 0.158 & 0.25 & 0.156 & $0.017^{*}$ & 0.806 \\
\hline Vascular Cover & 48 & 161 & $.017^{*}$ & 0.34 & $.004 *$ & 0.336 & 0.970 \\
\hline Cyperaceae Cover & 38 & 100 & $0.003^{*}$ & 0.39 & 0.098 & $<.0001^{*}$ & 0.589 \\
\hline Grass Cover & 20 & 22 & $<.0001 *$ & 0.55 & $<.0001^{*}$ & $0.024 *$ & 0.597 \\
\hline Forb Cover & 17 & 29 & $<.0001^{*}$ & 0.61 & $<.0001^{*}$ & 0.48 & 0.33 \\
\hline Shrub Cover & 12 & 11 & $<.0001^{*}$ & 0.64 & $0.027^{*}$ & $<.0001^{*}$ & $0.001^{*}$ \\
\hline Bryophyte Cover & 16 & 34 & $<.0001^{*}$ & 0.84 & $<.0001^{*}$ & $0.04^{*}$ & 0.14 \\
\hline Vascular Diversity & 3 & 10 & $<.0001 *$ & 0.73 & $<.0001^{*}$ & $.0001 *$ & $<.0001 *$ \\
\hline Forb Diversity & 1 & 4 & $<.0001^{*}$ & 0.84 & $<.0001^{*}$ & $.0001^{*}$ & $<.0001^{*}$ \\
\hline Bare Peat & 15 & 19 & $<.0001^{*}$ & 0.66 & $<.0001^{*}$ & $<.0001^{*}$ & $.036^{*}$ \\
\hline Litter & 17 & 34 & $<.0001^{*}$ & 0.61 & $<.0001^{*}$ & $<.0001^{*}$ & 0.493 \\
\hline
\end{tabular}

* = Significant at the alpha $=0.05$ level.

$\wedge=y 1$ mean is the mean value for the given parameter across the three treatments types and undisturbed vegetation plots. 
Appendix 2.1A. Variation in porewater parameters for restored (no mulch) vegetation among the four sectors at the Sleeper Lake Fen restoration site (20102011). Values are an average of the 5 replicates per sector.

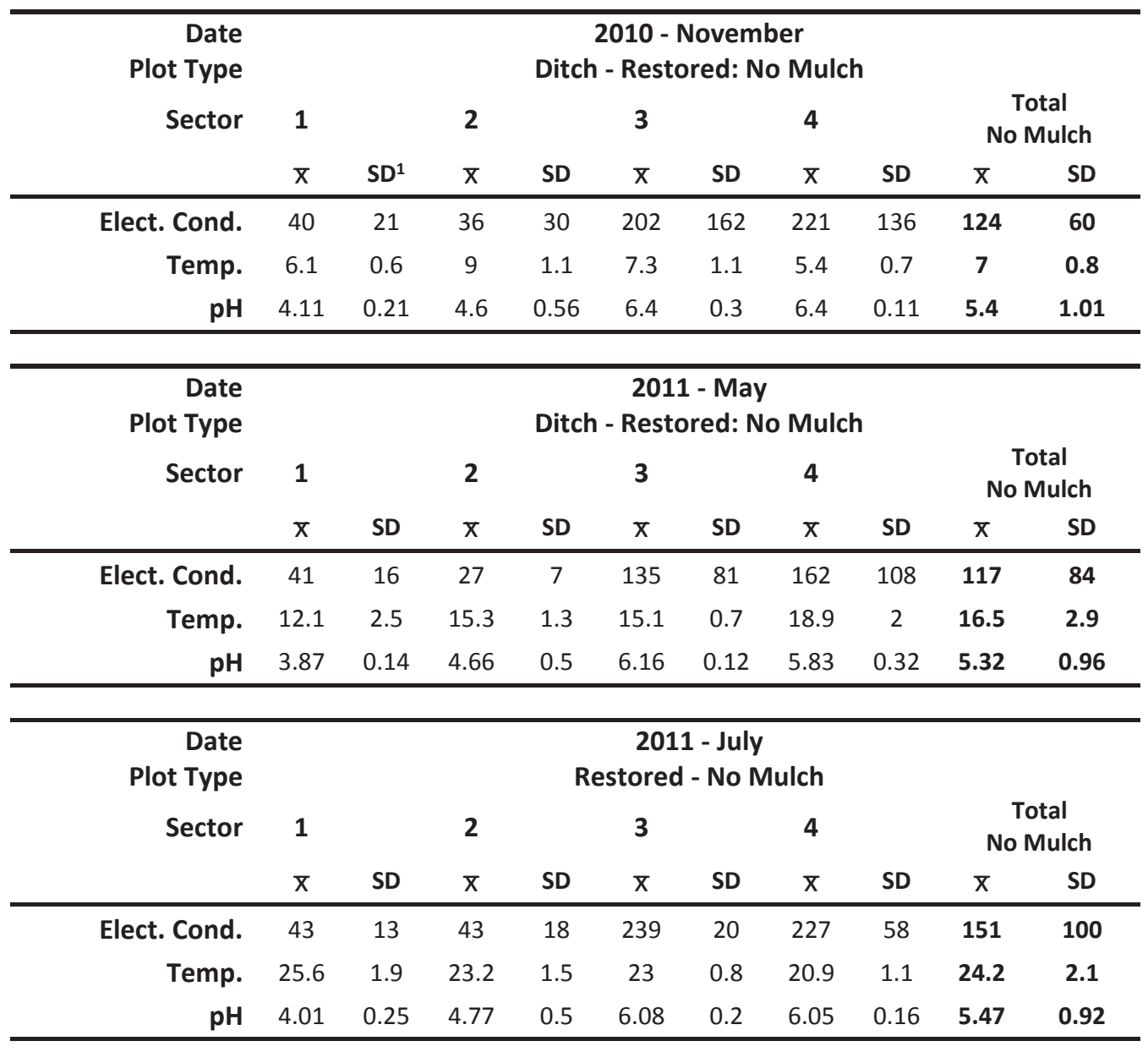

1: $\mathrm{SD}=$ Standard deviation 
Appendix 2.1B. Variation in porewater parameters for undisturbed vegetation among the four sectors at the Sleeper Lake Fen restoration site (2010-2011). Values are an average of the 5 replicates per sector.

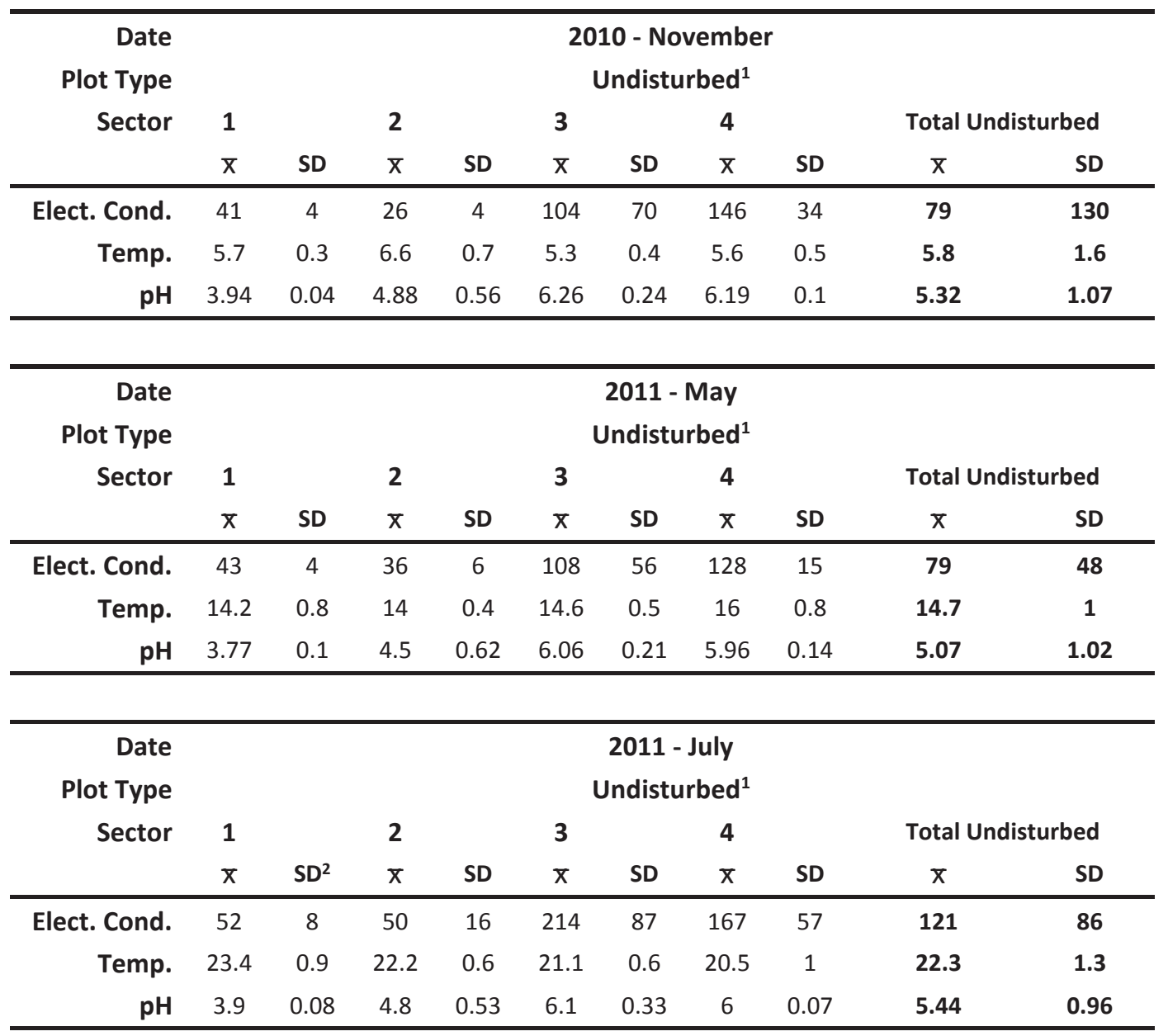

1: Undisturbed value is average of east and west side values

2: $\mathrm{SD}=$ Standard deviation 
Appendix 2.2. Variation in mean percent vegetative cover among the 4 sectors and 3 treatment types from 2010 to 2011 at the Sleeper Lake Fen restoration.

\begin{tabular}{|c|c|c|c|c|c|c|c|c|c|c|c|c|c|c|c|c|c|c|c|c|}
\hline \multirow{3}{*}{$\begin{array}{r}\text { Year } \\
\text { Plot Type } \\
\text { Sector }\end{array}$} & \multicolumn{10}{|c|}{$\begin{array}{c}2010 \text { (August) } \\
\text { Restored - Mulch }\end{array}$} & \multicolumn{10}{|c|}{$\begin{array}{c}2011 \text { (August) } \\
\text { Restored - Mulch }\end{array}$} \\
\hline & \multicolumn{2}{|c|}{1} & \multicolumn{2}{|c|}{2} & \multicolumn{2}{|c|}{3} & \multicolumn{2}{|c|}{4} & \multicolumn{2}{|c|}{ Mean } & \multicolumn{2}{|c|}{1} & \multicolumn{2}{|c|}{2} & \multicolumn{2}{|c|}{3} & \multicolumn{2}{|c|}{4} & \multicolumn{2}{|c|}{ Mean } \\
\hline & $\mathbf{x}$ & SD & $\mathbf{x}$ & SD & $\mathbf{x}$ & SD & $\mathbf{x}$ & SD & $\mathbf{x}$ & SD & $\mathbf{x}$ & SD & $\mathbf{x}$ & SD & $\mathbf{x}$ & SD & $\mathbf{x}$ & SD & $\mathbf{x}$ & SD \\
\hline Total Veg. & 159 & 38 & 139 & 22 & 118 & 67 & 169 & 40 & 146 & 45 & 228 & 31 & 223 & 90 & 197 & 71 & 209 & 54 & 214 & 66 \\
\hline Vascular & 111 & 48 & 123 & 14 & 113 & 65 & 166 & 41 & 128 & 47 & 148 & 33 & 176 & 70 & 194 & 69 & 207 & 52 & 181 & 62 \\
\hline Cyperaceae & 88 & 33 & 78 & 36 & 54 & 37 & 69 & 18 & 72.4 & 31 & 146 & 34 & 137 & 72 & 103 & 37 & 106 & 32 & 123 & 50 \\
\hline Grasses & 3 & 2 & 9 & 8 & 19 & 7 & 49 & 40 & 20.1 & 26 & 0 & 0 & 19 & 18 & 39 & 20 & 49 & 37 & 27 & 29 \\
\hline Forbs & 4 & 2 & 35 & 2 & 35 & 18 & 40 & 14 & 28.6 & 20 & 0.6 & 0.8 & 19 & 9 & 44 & 18 & 46 & 29 & 28 & 26 \\
\hline Bryophytes & 61 & 10 & 16 & 12 & 4 & 4 & 3 & 2 & 21.1 & 25 & 80 & 5.5 & 47 & 31 & 2.8 & 4.3 & 2 & 4 & 33 & 36 \\
\hline Shrubs & 2 & 1 & 1 & 2 & 5 & 7 & 7 & 4 & 4 & 4 & 1.4 & 2 & 0.6 & 1.2 & 8.4 & 12 & 7 & 7.5 & 4 & 8 \\
\hline Diversity & 19 & 2 & 26 & 2 & 34 & 7 & 32 & 3 & 27.8 & 6 & 12 & 2 & 10 & 5 & 35 & 5 & 29 & 5 & 22 & 6 \\
\hline Bare Peat & 28 & 11 & 43 & 16 & 58 & 30 & 20 & 14 & 37.3 & 22 & 2 & 2 & 16 & 19 & 50 & 19 & 39 & 16 & 27 & 24 \\
\hline Open Water & 0 & 0 & 0 & 0 & 0 & 0 & 0 & 0 & 0 & 0 & 0 & 0 & 5 & 10 & 0 & 0 & 0 & 0 & 1 & 6 \\
\hline Litter & 0 & 0 & 0 & 0 & 5 & 7 & 0 & 0 & 1 & 4 & 19 & 17 & 20 & 7 & 18 & 9 & 37 & 19 & 23 & 16 \\
\hline $\begin{array}{r}\text { Year } \\
\text { Plot Type }\end{array}$ & \multicolumn{10}{|c|}{ Restored - No Mulch } & \multicolumn{10}{|c|}{$\begin{array}{r}2011 \text { (August) } \\
\text { Restored - No M }\end{array}$} \\
\hline \multirow[t]{2}{*}{ Sector } & \multicolumn{2}{|c|}{1} & \multicolumn{2}{|c|}{2} & 3 & 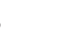 & 4 & 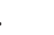 & $\mathrm{Me}$ & & & & & 2 & & 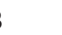 & 4 & 1 & $\mathrm{Me}$ & an \\
\hline & $\mathbf{x}$ & SD & $\mathbf{x}$ & SD & $\mathbf{x}$ & SD & $\mathbf{x}$ & SD & $\mathbf{x}$ & SD & $\mathrm{x}$ & SD & $\mathrm{x}$ & SD & $x$ & SD & $\mathbf{x}$ & SD & $\mathbf{x}$ & SD \\
\hline Total Veg. & 151 & 32 & 138 & 39 & 138 & 74 & 195 & 41 & 156 & 53 & 237 & 34 & 194 & 73 & 201 & 78 & 224 & 55 & 214 & 64 \\
\hline Vascular & 111 & 32 & 129 & 33 & 137 & 81 & 190 & 34 & 142 & 54 & 157 & 32 & 161 & 49.1 & 200 & 86.4 & 221 & 56.7 & 185 & 59 \\
\hline Cyperaceae & 101 & 34 & 80 & 42 & 62 & 33 & 71 & 17 & 78.5 & 32 & 153 & 34 & 122 & 47.8 & 119 & 59.1 & 86 & 33.8 & 120 & 47 \\
\hline Grasses & 5 & 0.4 & 10 & 9 & 32 & 32 & 56 & 26 & 25.8 & 28 & 2 & 3 & 16 & 17.1 & 38 & 43.6 & 71 & 14.7 & 32 & 34 \\
\hline Forbs & 3 & 2 & 36 & 18 & 39 & 22 & 57 & 25 & 33.8 & 26 & 0.4 & 1 & 22 & 18 & 39 & 21.5 & 55 & 32.4 & 29 & 28 \\
\hline Bryophytes & 40 & 17 & 9 & 8 & 2 & 2 & 5 & 7 & 14 & 18 & 80 & 6 & 33 & 37.3 & 1 & 2 & 3 & 4 & 29 & 36 \\
\hline Shrubs & 1 & 1 & 3 & 2.95 & 4 & 5 & 6 & 5 & 4 & 4 & 2 & 3 & 1 & 1 & 4 & 8 & 7 & 8 & 4 & 6 \\
\hline Diversity & 18 & 2 & 28 & 2 & 33 & 5 & 28 & 3 & 26.8 & 5 & 11 & 1.4 & 19 & 1 & 29 & 4 & 31 & 4 & 23 & 4 \\
\hline Bare Peat & 33 & 12 & 44 & 23 & 45 & 28 & 16 & 1 & 34.6 & 21 & 5 & 4 & 14 & 16.7 & 38 & 26.6 & 25 & 15 & 21 & 20 \\
\hline Open Water & 0 & 0 & 0 & 0 & 0 & 0 & 0 & 0 & 0 & 0 & 0 & 0 & 0 & 0 & 0 & 0 & 0 & 0 & 0 & 0 \\
\hline Litter & 0 & 0 & 0 & 0 & 5 & 7 & 0 & 0 & 1 & 4 & 15 & 12 & 18 & 15.2 & 20 & 24.5 & 49 & 21.9 & 25 & 22 \\
\hline $\begin{array}{r}\text { Year } \\
\text { Plot Type }\end{array}$ & & & & $\begin{array}{r}2 \\
\text { estor }\end{array}$ & $\begin{array}{l}107 A \\
\text { ed - C }\end{array}$ & $\begin{array}{l}\text { ugus } \\
\text { ontro }\end{array}$ & & & & & & & & $\begin{array}{r}2 \\
\operatorname{Res}\end{array}$ & $\begin{array}{l}011(1 / \\
\text { tored }\end{array}$ & $\begin{array}{l}\text { iugust } \\
\text { - Con }\end{array}$ & trol & & & \\
\hline Sector & & . & & & 3 & & 4 & & $\mathrm{Me}$ & & & & & $?$ & & 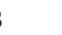 & 4 & & $\mathrm{Me}$ & an \\
\hline & $\mathbf{x}$ & SD & $\mathbf{x}$ & SD & $\mathbf{x}$ & SD & $\mathbf{x}$ & SD & $\mathbf{x}$ & SD & $\mathbf{x}$ & SD & $\mathbf{x}$ & SD & $\mathbf{x}$ & SD & $\mathbf{x}$ & SD & $\mathbf{x}$ & SD \\
\hline Total Veg. & 113 & 33 & 152 & 61 & 94 & 19 & 147 & 32 & 126 & 46 & 187 & 21 & 156 & 49 & 143 & 37 & 173 & 38 & 165 & 36 \\
\hline Vascular & 60 & 19 & 136 & 63 & 93 & 18 & 143 & 30 & 108 & 50 & 107 & 25 & 124 & 41 & 143 & 37 & 168 & 34 & 135 & 41 \\
\hline Cyperaceae & 51 & 26 & 64 & 30 & 46 & 15 & 61 & 13 & 55 & 23 & 93 & 31 & 76 & 25 & 72 & 23 & 84 & 18 & 81 & 26 \\
\hline Grasses & 0 & 0 & 8 & 9 & 11 & 6 & 44 & 32 & 16 & 24 & 0 & 0 & 7 & 14 & 13 & 12 & 41 & 18 & 15 & 20 \\
\hline Forbs & 0.2 & 0.4 & 52 & 23 & 32 & 9 & 36 & 10 & 30 & 23 & 0 & 0 & 39 & 18 & 53 & 6.4 & 41 & 24 & 33 & 25 \\
\hline Bryophytes & 53 & 23 & 16 & 9 & 1 & 1.3 & 4 & 6 & 18 & 24 & 80 & 5.5 & 32 & 28 & 0 & 0 & 5 & 6.3 & 29 & 35 \\
\hline Shrubs & 9 & 8.6 & 11 & 17 & 4 & 6.6 & 2 & 2 & 7 & 11 & 14 & 13 & 2 & 4 & 5 & 7.7 & 2 & 2.4 & 6 & 9.4 \\
\hline Diversity & 12 & 2 & 24 & 3 & 21 & 1 & 28 & 3 & 21 & 6 & 9 & 1 & 18 & 3 & 24 & 2 & 28 & 3 & 20 & 3 \\
\hline Bare Peat & 43 & 22 & 45 & 22 & 75 & 8.4 & 43 & 14 & 52 & 22 & 4 & 5 & 12 & 19 & 63 & 12 & 25 & 21 & 26 & 27 \\
\hline Open Water & 0 & 0 & 0 & 0 & 0 & 0 & 0 & 0 & 0 & 0 & 0 & 0 & 10 & 20 & 0 & 0 & 0 & 0 & 2.5 & 12 \\
\hline Litter & 0 & 4 & 0 & 0 & 5 & 7.7 & 0 & 0 & 1 & 4 & 25 & 18 & 17 & 19 & 13 & 5 & 47 & 25 & 25 & 22 \\
\hline
\end{tabular}


Appendix 2.3. Plant species richness and distribution at the Sleeper Lake Fen restoration site (2010-2011). $1=$ presence , blank $=$ absence; Undist. $=$ undisturbed fen .

\begin{tabular}{|c|c|c|c|c|c|c|c|c|c|c|c|c|c|c|}
\hline Species & $\begin{array}{r}\mathrm{Di} \\
2010\end{array}$ & $\begin{array}{l}\text { ch } \\
2011\end{array}$ & $\begin{array}{l}\text { Undist. } \\
2010\end{array}$ & $\mid \begin{array}{c}\text { Dit } \\
2010\end{array}$ & $\begin{array}{l}\text { tch } \\
2011\end{array}$ & $\begin{array}{l}\text { Undist } \\
2010\end{array}$ & $\mid \begin{array}{r}\text { Dit } \\
2010\end{array}$ & $\begin{array}{l}\text { tch } \\
2011\end{array}$ & $\begin{array}{c}\text { Undist. } \\
2010\end{array}$ & $\begin{array}{r}\mathrm{Di} \\
2010\end{array}$ & 2011 & $\begin{array}{c}\text { Undist. } \\
2010\end{array}$ & \begin{tabular}{|l} 
Spp. R \\
Ditch
\end{tabular} & $\begin{array}{l}\text { ichness } \\
\text { Undist. }\end{array}$ \\
\hline Agrostis hyemalis & & & & 1 & & & 1 & 1 & & 1 & 1 & & 1 & \\
\hline Alnus rugosa & & & & & & & & & & & & 1 & & 1 \\
\hline Andromeda polifolia & & & & & & 1 & & & & & & & & 1 \\
\hline Aronia melanocarpa & 1 & & & 1 & 1 & & 1 & 1 & & 1 & & & 1 & \\
\hline Betula papyrifera & 1 & & & & & & & & & & & & 1 & \\
\hline Betula pumila & 1 & 1 & 1 & & & 1 & 1 & 1 & 1 & 1 & 1 & & 1 & 1 \\
\hline Bidens cernua & & & & & & & & 1 & & & & & 1 & \\
\hline Calamagrostis canadensis & 1 & 1 & & 1 & 1 & 1 & 1 & 1 & 1 & 1 & 1 & 1 & 1 & 1 \\
\hline Campanula aparinoides & & & & & 1 & & 1 & 1 & 1 & 1 & 1 & 1 & 1 & 1 \\
\hline Carex canescens & & 1 & & & 1 & & & & & & & & 1 & \\
\hline Carex lasiocarpa & & & & 1 & 1 & & 1 & 1 & 1 & 1 & 1 & 1 & 1 & 1 \\
\hline Carex magellanica & 1 & 1 & 1 & & 1 & 1 & & & 1 & & & & 1 & 1 \\
\hline Carex oligosperma & 1 & 1 & 1 & 1 & 1 & 1 & & 1 & & & & & 1 & 1 \\
\hline Carex sterilis & & & & & & & & 1 & 1 & & 1 & 1 & 1 & 1 \\
\hline Carex stricta & & & & & & & & & 1 & & 1 & & 1 & 1 \\
\hline Carex utriculata & 1 & 1 & & 1 & & 1 & 1 & 1 & 1 & & & 1 & 1 & 1 \\
\hline Carex sp. & 1 & & & 1 & & & 1 & 1 & & 1 & 1 & & 1 & \\
\hline Chamaedaphne calyculata & 1 & 1 & 1 & 1 & 1 & 1 & & & & & & & 1 & 1 \\
\hline Cicuta bulbifera & & & & 1 & & & 1 & 1 & 1 & 1 & 1 & 1 & 1 & 1 \\
\hline Cladonia lichens & & & 1 & & & & & & & & & & & 1 \\
\hline Doellingeria umbellata & & & & 1 & & & 1 & 1 & & 1 & 1 & & 1 & \\
\hline Dulichium arundinaceum & 1 & 1 & & 1 & 1 & & 1 & 1 & & 1 & 1 & & 1 & \\
\hline Epilobium leptophyllum & 1 & & & & & & & & & 1 & & & 1 & \\
\hline Equisetum sp. & & & & & & & 1 & 1 & & 1 & 1 & & 1 & \\
\hline Eriophorum tenellum & & & & 1 & 1 & & & & & & & & 1 & \\
\hline Eriophorum virginicum & 1 & 1 & & 1 & 1 & & 1 & 1 & & & 1 & & 1 & \\
\hline Eriophorum viridi-carinatum & & 1 & 1 & 1 & & & & 1 & 1 & & 1 & 1 & 1 & 1 \\
\hline Euthamia graminifolia & & & & & & & & 1 & & & & & 1 & \\
\hline Feather Moss & & & & 1 & & 1 & 1 & 1 & & 1 & 1 & 1 & 1 & 1 \\
\hline Galium brevipes & & & & 1 & 1 & 1 & 1 & 1 & 1 & 1 & 1 & 1 & 1 & 1 \\
\hline Glyceria canadensis & & & & 1 & 1 & & 1 & 1 & 1 & 1 & 1 & & 1 & 1 \\
\hline Iris versicolor & 1 & 1 & & 1 & 1 & 1 & 1 & 1 & 1 & 1 & 1 & 1 & 1 & 1 \\
\hline Juncus spp. & 1 & & & 1 & & & 1 & & & 1 & 1 & & 1 & \\
\hline Larix laricina & & & 1 & & & & & & & & & & & 1 \\
\hline Lycopus uniflorus & & & & 1 & 1 & 1 & 1 & 1 & 1 & 1 & 1 & 1 & 1 & 1 \\
\hline Lysimachia terrestris & & & & 1 & 1 & 1 & 1 & 1 & 1 & 1 & 1 & 1 & 1 & 1 \\
\hline Marchantia sp. & & & & & & & & & & 1 & 1 & & 1 & \\
\hline moss spp. & & & & & & & & & 1 & 1 & & & 1 & 1 \\
\hline Oclemena nemoralis & & 1 & & 1 & & & & & & & 1 & & 1 & \\
\hline Pinus resinosa & & & 1 & & & & & & & & & & & 1 \\
\hline $\begin{array}{l}\text { Polytrichum spp. } \\
\text { Populus tremuloides }\end{array}$ & 1 & & 1 & 1 & 1 & 1 & 1 & 1 & 1 & $\begin{array}{l}1 \\
1\end{array}$ & 1 & 1 & $\begin{array}{l}1 \\
1\end{array}$ & 1 \\
\hline
\end{tabular}


Appendix 2.3 cont'd. Plant species richness and distribution at the Sleeper Lake Fen restoration site (2010-2011).

$1=$ presence, blank $=$ absence; Undist. $=$ undisturbed fen .

\begin{tabular}{|c|c|c|c|c|c|c|c|c|c|c|c|c|c|c|}
\hline \multirow{2}{*}{ Species } & \multicolumn{3}{|c|}{ Sector 1} & \multicolumn{3}{|c|}{ Sector 2} & \multicolumn{3}{|c|}{ Sector 3} & \multicolumn{3}{|c|}{ Sector 4} & \multirow{2}{*}{\multicolumn{2}{|c|}{$\begin{array}{l}\text { Total Plant } \\
\text { Spp. Richnes }\end{array}$}} \\
\hline & \multicolumn{2}{|c|}{ Ditch } & Undist & \multicolumn{3}{|c|}{ Ditch Undist } & \multicolumn{3}{|c|}{ Ditch Undist } & & Ditch & $\begin{array}{l}\text { Undist } \\
1 \quad 2010\end{array}$ & & \\
\hline Potentilla palustris & 1 & & & 1 & 1 & & 1 & & 1 & 1 & & 1 & 1 & 1 \\
\hline Potentilla sp. 2 & & & & & & & & & & 1 & 1 & & 1 & \\
\hline Rubus spp. & & & & & & & & 1 & & 1 & 1 & & 1 & \\
\hline Rumex orbiculatus & 1 & & & 1 & & & 1 & 1 & & 1 & 1 & & 1 & \\
\hline Salix spp. & & & & 1 & 1 & & 1 & 1 & 1 & 1 & 1 & 1 & 1 & 1 \\
\hline Sarracenia purpurea & & & 1 & & & & & & & & & & & 1 \\
\hline Scirpus atrovirens & 1 & & & & 1 & & 1 & 1 & & 1 & 1 & & 1 & \\
\hline Scirpus cyperinus & & 1 & & & 1 & & 1 & 1 & & 1 & 1 & & 1 & \\
\hline Scutellaria galericulata & & & & & & & 1 & 1 & 1 & 1 & 1 & 1 & 1 & 1 \\
\hline Smilacina trifolia & & & & & & & 1 & 1 & & & & 1 & 1 & 1 \\
\hline Solidago uliginosa & 1 & & & 1 & & & 1 & 1 & 1 & 1 & 1 & 1 & 1 & 1 \\
\hline Sparganium sp. (?) & & & & 1 & & & & & & & & & 1 & \\
\hline Sphagnum spp. & 1 & 1 & 1 & 1 & 1 & 1 & 1 & 1 & 1 & 1 & 1 & 1 & 1 & 1 \\
\hline Spirea alba & & & & & & & 1 & 1 & 1 & 1 & 1 & & 1 & 1 \\
\hline Symphyotrichum boreale & & & & & & & 1 & 1 & & 1 & 1 & 1 & 1 & 1 \\
\hline Triadenum fraseri & & & & 1 & 1 & 1 & 1 & & 1 & 1 & & 1 & 1 & 1 \\
\hline Typha latifolia & & & & & & & & 1 & & & & & 1 & \\
\hline Utricularia spp. & & & & 1 & & & 1 & 1 & 1 & & & & 1 & 1 \\
\hline Vaccinium angustifolium & & & 1 & & & & & & & & & & & 1 \\
\hline Vaccinium macrocarpon & 1 & 1 & 1 & 1 & & 1 & 1 & 1 & 1 & & & 1 & 1 & 1 \\
\hline Vaccinium myrtilloides & & & 1 & & & & & & & & & & & 1 \\
\hline Viburnum cassinoides & 1 & & & & & & 1 & & & & & & 1 & \\
\hline Viola (hybrid?) & & & & & & & & & 1 & & & & & 1 \\
\hline Viola lanceolata & & & & 1 & & & & & & & & & 1 & \\
\hline Viola mackloskeyi & & & & & & 1 & 1 & 1 & & 1 & 1 & & 1 & 1 \\
\hline Total Taxa & 22 & 15 & 14 & 33 & 23 & 17 & 37 & 40 & 27 & 37 & 36 & 23 & 58 & 40 \\
\hline
\end{tabular}




\section{Chapter 3.0 Gradients in Pore water Chemistry and Vegetation in a Restored Northern Michigan Fen ${ }^{2}$}

\subsection{Abstract}

In 2009, a wetland firebreak restoration project was initiated at a large, previously pristine, fen complex in Michigan's Upper Peninsula (Sleeper Lake Fen). The site had experienced a large-scale wildfire during an extended drought in 2007 and many firebreaks were dug throughout the fen complex. When water levels returned to normal, many of these firebreaks became water-filled ditches, some with appreciable flow. A 1.6 $\mathrm{km}$ long ditch was selected for intensive, experimental restoration - replacing the excavated peat and planting with a native seed mix. A pore water sampling plan was also implemented, to track changes in water chemistry in the undisturbed and restored fen over time. We identified strong, within-site gradients in pore water chemistry, particularly in $\mathrm{Ca}, \mathrm{Fe}, \mathrm{Mg}$ and $\mathrm{Zn}$, that corresponded with gradients in vegetative parameters in both the restored ditch and adjacent undisturbed fen. The effects of these chemical gradients on plant species colonization and establishment in the restored ditch is discussed and compared with the conditions in the undisturbed fen and the results of other fen studies.

2: Bess, J., R. Chimner, J. Hribljan and E. Kane. 2015. Gradients in Pore water Chemistry and Vegetation in a Restored Northern Michigan Fen. Manuscript. 


\subsection{Introduction}

Fens are a specific type of peatland sustained by surface or ground water inputs, as opposed to bogs that receive the vast majority of their water from rainfall (Rydin and Jeglum, 2006). Ground and surface water typically contain dissolved minerals such as $\mathrm{Ca}, \mathrm{Fe}, \mathrm{Mg}$ and $\mathrm{Mn}$ (which are often absent or in low concentrations in rainwater) and these habitats support unique floras and faunas, often containing species of conservation concern (Spiels, 1999; Bedford and Godwin, 2003; Cohen and Kost, 2008; Cohen et al., 2010).

Changes in water chemistry can occur when fens are degraded through peat mining, draining or conversion to agricultural and silvicultural production, especially when diversionary ditches cut-off the flow of mineral-rich groundwater to the wetland. Nutrient levels are also altered, typically leading to spikes in total nitrogen, phosphorous and/or sulfur (DeMars et al., 1996; Boeye, et al., 1997; van Duren et al., 1997; Olde Venterink et al., 2001; Hajkova and Hajek, 2003; Rozbrojová and Hajek, 2008; Zak et al., 2008-2009). Accumulation of metals is an additional concern, particularly iron, which can build up to levels that have been shown to negatively impact the growth and survival of certain fen plants (Snowden and Wheeler, 1993).

In conjunction with habitat fragmentation, these human-caused water table manipulations and resultant changes in pore water chemistry have caused the rapid replacement of many temperate zone native fen floras with aggressive wetland habitat generalist and non-native or upland plant species which can require many years of control efforts to remove and replace with native species (Boelter, 1972, Beltman et al., 1996, De 
Mars et al., 1996, Fisher et al., 1996, Hald and Vinther, 2000, Large, 2001, Patzelt et al., 2001, Cobbaert et al., 2004, Jansen et al., 2004, Anshaari et al., 2010, Klimkowska et al., 2010, Soomers et al., 2013). Given these hazards, it is important to develop a well thought out plan prior to implementing restoration, especially when funds, materials and labor are limited (Grootjans and Van Diggelen, 1995, Lode, 1999, Joosten and Clark, 2002, Clewell et al., 2005, Trepel, 2007, van Loon, 2009). Fundamental to the success of such a plan is an understanding of the hydrology and pore water chemistry of a given site and how these abiotic factors can affect the establishment and proliferation of plant species used in the restoration (Van Duren et al., 1998, Price et al., 2003, Andersen et al., 2006, Page et al., 2009, Lamers et al., 2015).

In this paper, we detail a restoration project implemented in 2009 at a large fen in northern Michigan, USA and discuss the potential effects of pore water chemistry on the success of our restoration project. The restoration site is part of the 20,000 hectare Sleeper Lake Fen complex in central Luce County. In August of 2007, a drought and lightning- induced wildfire burned more than 7,200 hectares of fen, conifer swamp and pine barrens. As part of the fire-fighting program, bulldozers were used to create $48 \mathrm{~km}$ of firebreaks around and in the wetland. Firebreaks in the open fen and conifer swamp became water-filled ditches following a rise in the local water table in 2008. Our restoration project restored a 2.6 kilometer section of ditch through open fen at the south end of the burn area (lat. $46^{\circ} 27^{\prime} 13.23^{\prime \prime} \mathrm{N}$ long. $85^{\circ} 28^{\prime} 33.01^{\prime \prime} \mathrm{W}$ ) by returning peat spoils and revegetating with native plant seeds and moss diaspores in. Undisturbed vegetation along the ditch varied considerably from the southern to northern end so we divided the 
ditch into 4 sectors, based on these differences, as part of our experimental design. In each sector, we planted identical seed and moss mixtures to test how plant germination and growth was altered by ditching and pore water chemistry. These seed mixes were composed of species occurring in the adjacent burned and unburned fen at Sleeper Lake. Pore water sampling was undertaken following initial restoration. Fen plant species are known to be sensitive to pore water chemistry, so we wanted to determine if plant species composition in the undisturbed fen varied with changes in concentration of certain pore water chemical components. We were also interested in how the pore water chemistry in the restored ditch might vary from that in the adjacent undisturbed fen and if there was differential germination and establishment among the plant species used in our ditch restoration in relation to these chemical components. Finally, we wanted to monitor whether porewater and vegetative characteristics in the restored ditch became more like those of the undisturbed fen or developed along a different trajectory.

Our objectives were to 1.) Quantify if changes in vegetative composition in the undisturbed fen corresponded with changes in pore water chemistry; 2.) Document establishment and vegetative cover among the plant species in our seed mixture relative to pore water chemical components; 3.) Determine if variability in pore water chemistry related to overall re-vegetation success in the restored ditch, and 4.) Determine if vegetation and pore water characteristics in the restored ditch became more like those of the adjacent, undisturbed fen over time or developed along different trajectories. 


\subsection{Methods}

\subsubsection{Study Site}

In 2009, a ditch restoration project was implemented at the Sleeper Lake Fen complex in Michigan's Upper Peninsula (Bess et al., 2014, Figure 3.1). This fen complex is part of the larger Two-Hearted Lowlands region which serves as the headwaters for several rivers and streams that feed into Lake Superior. Average annual high temperatures ranges from $-4.4^{\circ} \mathrm{C}$ in January to $25.5^{\circ} \mathrm{C}$ in July and annual precipitation averages $78.38 \mathrm{~cm}$ and peaks in August-September (USDA-NRCS, 2012a). Following a protracted drought in 2007, the fen complex experienced a large-scale wildfire event in August of that year which burned for three months. During firefighting operations, the Michigan Department of Natural Resources (MIDNR) bulldozed over 48 $\mathrm{km}$ of firebreaks in and around the fen.

The peat at our study site is very dense (1-2 m thick) and dominated by sedge and grass remains, with pockets of Sphagnum-dominated peat. The lowermost peat layers are highly humified, dark brown to black peat and muck and sit on a bed of mucky fine sand. The wetland soils adjacent to the larger sand dunes of Rousseau Fine Sands are classified as Dawson-Greenwood-Loxley mucks and mucky peats, while the majority of the peat in the open fen is listed as Histosols of peat and muck or Aquents, depending on the degree of ponding (USDA-NRCS, 2012a). The firebreaks within the peatland were dug down to the mineral soil layer in most cases, completely disturbing the peat profile. Once rainfall restored the water table to pre-drought conditions, the firebreaks became water-filled ditches, many with appreciable flow. Bess et al., 2014 addressed the experimental 
design, methods of restoration and initial response of vegetation in a $1.6 \mathrm{~km}$ long sector of ditch and how differences in basic pore water parameters affected the vegetation response in the restored ditch. This study examines additional pore water characteristics such as elemental composition, dissolved organic carbon (DOC) and macronutrients at this site and how these may have affected the success of the restoration and distribution of plant species along the restored ditch.

\subsubsection{Experimental Design}

The ditch was divided into 4 sectors based on variation in undisturbed vegetation adjacent to the ditch as detailed in Bess et al., 2014. For our experimental plantings, we hand collected seeds of 18 species of native wetland plants and diaspores of 6 moss species. For the ditch restoration, $60,3 \times 3$ meter square restoration plots were established, with five replicates of three experimental planting treatments consisting of: 1) no plant - control, 2) seed only, and 3) seed, moss diaspores and mulch. These plots were placed in the center of the former ditch, in physically similar areas of restored peat within each sector. Inundated areas were avoided, as were large sections of turf and woody debris. Plot placement within each set of 3 treatment types was randomly chosen to reduce potential bias. For vegetation monitoring, $1 \times 1 \mathrm{~m}$ square quadrats were placed in the center of each ditch restoration plot and 5 on each side of the ditch (per sector) in adjacent undisturbed fen (and roughly parallel to the ditch no mulch quadrats) but 3-4 meters from the edge of the ditch. This provided a total of 100 vegetation sampling quadrats - 60 in the ditch and 40 in adjacent undisturbed fen. The placement of 
vegetation sampling quadrats was done to minimize edge effect in both the ditch and the undisturbed fen.

Groundwater monitoring wells were placed along the ditch line to record fen hydrology, initially a single pair in Sector 2 (1 on each side of ditch) prior to restoration and then 3 more pairs (one pair each in sectors 1, 3 and 4) following restoration. Monitoring wells consisted of $1.5 \mathrm{~m}$ long sectors of $8 \mathrm{~cm}$ dia. perforated PVC pipe inserted to the mineral soil. The outer portion of the well was covered with nylon landscaping mesh and secured with zip-ties. The bottom of the well was covered with a PVC cap to prevent infiltration of peat. Solinst ${ }^{\mathrm{TM}}$ Leveloggers (Georgetown, ON, Canada) were placed in each well to provide daily monitoring of the water table. A Solinst ${ }^{\mathrm{TM}}$ Barologger placed in one of the wells in Sector 2 provided barometric compensation for all pressure transducers.

\subsubsection{Vegetation Sampling}

Vegetation composition and cover data were collected from each of the 60, 1-m square ditch research quadrats in August of 2010 and 2011. Data on undisturbed vegetation was collected in August, 2010 from 40 1-m square quadrats (5 on each side of ditch in each sector (10 per sector) placed in undisturbed fen vegetation adjacent to the ditch and parallel to each of the no mulch treatment plots. Data on the undisturbed vegetation was collected only in 2010, as species composition and cover in these plots was not observed to change greatly over the 2-year period and the thick layer of Carex litter inhibited the growth of any additional seedlings. 
For the purposes of this study, "undisturbed" fen refers to the vegetation and peat next to the ditch that was not excavated during firebreak construction. It is understood that this fen had tracked vehicle traffic along both sides of the ditch during firebreak excavation and restoration (in addition to a recent, hot fire) and therefore is not technically undisturbed. This term is used solely to compare the newly restored and highly disturbed ditch with the unditched fen habitat adjacent to it. Vegetation and pore water sampling in the undisturbed fen was undertaken $\sim 4$ meters away from the edge of the ditch, presumably outside the track width of the bulldozer used for firebreak creation and the excavator used for restoration. The peat surface and vegetation in this sampling zone was visually undistinguishable from adjacent fen further away from the ditch.

Plants were identified to species whenever possible, although many vegetative sedges, grasses and young mosses could only be determined to genus. Voss' threevolume "Michigan Flora" (Voss, 1972, 1985, 1996) was used for determinations and the most recent names of our flora were obtained from Voss and Reznicek (2012) and the USDA PLANTS Database (USDA-NRCS, 2012b). Vegetative cover was estimated visually by two observers and a consensus was reached for each species to the nearest percentage point. Cover was assessed on a per-species or taxon basis and, given the multiple strata of plant growth, total vegetative cover for individual quadrats often exceeded $100 \%$ when values for individual species/taxa were tallied together. 


\subsubsection{Pore water Sampling and Analysis}

Pore water sampling was undertaken in November 2010, early May 2011 and late July 2011 to track changes across a growing season. Samples were collected with a 500 $\mathrm{ml}$ syringe attached by Nalgene tubing (with a stopcock) to a $1.5 \mathrm{~m}$ sector of $0.64 \mathrm{~cm}$ dia. stainless steel tube (similar to a Pushpoint Sampler ${ }^{\mathrm{TM}}$ as described by US EPA (US EPA, 2013)). All pore water samples were collected at $25 \mathrm{~cm}$ beneath the peat surface. Effort was made to minimize disturbance of the peat profile while collecting samples. During each sampling event, 60 samples were collected from along the length of the restored ditch; in each sector, 5 samples were collected from the restored ditch and 5 each from undisturbed vegetation on each side of the ditch (15 samples from each sector).

The ditch samples were taken from each of the "no mulch" research plots and the undisturbed samples were taken at points parallel with the no mulch plots and $\sim 3-4 \mathrm{~m}$ from the edge of ditch, where the undisturbed vegetation data were collected. Clumps of bushes and sedge tussocks were avoided. Prior to gathering each sample, the sampler tubing and syringe were placed in the peat and filled and purged several times with local water. Samples were taken for analysis only after excess organic matter (resulting from sampler insertion into the peat) had visibly dissipated from the local collection site and sampler. Temperature, electrical conductivity and $\mathrm{pH}$ were measured in the field using an YSI Model 63 hand-held meter. The $\mathrm{pH}$ meter was calibrated with $\mathrm{pH} 4$ and 7 buffers prior to each day's sampling effort, for each sampling period (Fall 2010, Spring 2011, 
Summer 2011). The sensor was rinsed thoroughly with distilled water (and then local water) between each sampling point to minimize potential for cross contamination.

Pore water samples were stored in $120 \mathrm{ml}$ high density polyethylene (HDPE) Nalgene bottles in a cooler on ice and were filtered through a Sterlitech ${ }^{\mathrm{TM}}$ (Sterlitech Corporation, Kent, WA) $0.45 \mu \mathrm{m}$ nylon membrane filter within 24 hours of collection, split into two 40-60 $\mathrm{ml}$ aliquots and one half fixed (acidified) with hydrochloric acid until $\mathrm{pH}$ was $\sim 2$ for dissolved organic carbon (DOC) and total dissolved nitrogen (TDN) analysis. Aliquots were placed in brown, opaque $60 \mathrm{ml} \mathrm{HDPE} \mathrm{Nalgene} \mathrm{bottles} \mathrm{and} \mathrm{those}$ being tested for organic acid, element, and ionic compounds frozen. A small aliquot $(\sim 5 \mathrm{ml})$ was placed in a glass vial and refrigerated for use in spectrophotometer analysis (SUVA 254$)$. Elemental analyses were conducted within 30 days of collection (using a PerkinElmer Optima DV inductively-coupled plasma optical emission spectrometer (ICPOES) - PerkinElmer Corporation, Waltham, MA) and included aluminum (Al), calcium (Ca), Iron (Fe), Potassium (K), Manganese (Mn), Magnesium (Mg), Phosphorus (P) and Zinc (Zn).

The organic acids and anions, Bromide $\left(\mathrm{Br}^{-}\right)$, chloride $\left(\mathrm{Cl}^{-}\right)$, fluoride $\left(\mathrm{F}^{-}\right)$, nitrate $\left(\mathrm{NO}_{3}{ }^{-}\right)$, nitrite $\left(\mathrm{NO}_{2}^{-}\right)$, phosphate $\left(\mathrm{PO}_{4}^{-3}\right)$, sulfate $\left(\mathrm{SO}_{4}^{-2}\right)$, acetate, propionate, formate, and oxalate were measured using a Dionex ICS 2000 Ion Chromatograph (Dionex Corporation, Bannockburn, IL, USA). The acidified samples were stored on ice, returned to lab, and refrigerated at $4^{\circ} \mathrm{C}$ prior to DOC and TDN analyses via a Shimadzu TOC-V Combustion Analyzer with a TNM-1 Total Nitrogen module (Shimadzu Scientific Instruments, Columbia, MD, USA) with a detection limit of $0.05 \mathrm{mg} \mathrm{L}^{-1}$ and $0.5 \mu \mathrm{g} \mathrm{L}^{-1}$ 
respectively. Pore water SUVA absorbance was measured at $\lambda=254 \mathrm{~nm}$ with a Spectramax M2 Microplate Reader (Molecular Devices LLC, Sunnyvale, CA) using a 1 cm quartz cuvette and reverse osmosis $(\mathrm{RO})$ water for the blank.

Specific ultraviolet absorbance $\left(\mathrm{SUVA}_{254}\right)$ was calculated from absorption at $\lambda=$ $254 \mathrm{~nm}$ divided by sample DOC concentration $\left(\mathrm{SUVA}_{254}\right.$ is reported in units of $\mathrm{L} \mathrm{mg} \mathrm{C}^{-1}$ $\mathrm{m}^{-1}$ ). Each sample was tested twice and if there was a discrepancy between the two subsamples, an average value was recorded. Discrepancies were in hundredths of milligrams. The value of $\mathrm{SUVA}_{254}$ is as an indicator of pore water aromaticity (Weishaar et al., 2003). This value can be affected by the presence of ferric iron $\left(\mathrm{Fe}^{+3}\right)$ because of UV absorbance by that iron species (Levia and Carlyle-Moses, 2011). Despite not measuring it directly, we likely had fairly high levels of ferric iron in some of our pore water samples given the presence of ferric iron precipitates throughout the northern half of the restoration site. The fall 2010 ditch sample SUVA $_{254}$ and Fe concentrations had a fairly high correlation $\left(r^{2}=0.53\right)$, as did the undisturbed samples $\left(r^{2}=0.49\right)$. The spring 2011 ditch samples were less strongly correlated $\left(r^{2}=0.23\right)$ as were the undisturbed samples $\left(r^{2}=0.38\right)$. Given this, there is an indication of pore water iron concentration (which was used as a proxy for $\mathrm{Fe}^{+3}$ ) affecting the $\mathrm{SUVA}_{254}$ readings for our samples, possibly making the readings from sectors 3 and 4 artificially high because of additional UV absorbance by ferric iron in the samples. 


\subsubsection{Statistical Analysis}

We compared total vascular species cover and diversity, grass, forb and sedge cover, forb diversity and moss cover to pore water parameters $\mathrm{Al}, \mathrm{Ca}, \mathrm{Fe}, \mathrm{Mg}, \mathrm{Mn}, \mathrm{Zn}$, DOC and TDN. Percent cover of individual plant species was also compared against various pore water constituents and comparisons were made between Sectors and undisturbed versus restored fen. Analysis of variance (nested ANOVA) was used to determine whether there were significant differences in the variation of pore water and vegetative parameters among the sectors and undisturbed versus restored fen. P-values $\leq$ 0.05 were considered statistically significant. Linear regression was used to calculate correlations between pore water and vegetative characteristics and select plant taxa (note: correlations between $\mathrm{pH}$, electrical conductivity and vegetative characteristics are given in Bess et al., 2014). SAS software (Proc-ANOVA, SAS Institute, Inc., Cary, NC) was used to calculate ANOVA's, while correlations, regression plots and equations were derived using SigmaPlot 12.0 (Systat Software, Inc., San Jose, CA).

To compare and contrast the floras of the restored and undisturbed fen, we used Nonmetric Multidimensional Scaling (NMS) ordination (PC-ORD 6.0, 2014 - MjM Software Design, Gleneden Beach, OR). The default settings for Sorenson's (BrayCurtis) distance measure were selected, with a maximum of 6 axes and 200 iterations. Starting coordinates were random, with 1 reduction in dimensionality at each cycle. No penalty was assessed for ties in values for a given species among the compared floras. The analysis used a total of 50 runs with real data and 50 with randomized data; we selected a medium speed vs thoroughness setting. To see how the pore water chemistry 
data might be affecting the distribution of plant species within our study area, we included pore water parameters as a secondary matrix to be run simultaneously with the vegetation data from the ditch and undisturbed fen. Pore water parameters included $\mathrm{pH}$, electrical conductivity, Ca, DOC, Fe, TDN, P and Zn. Matrix dimensionality was determined by selecting the solution with a final stress less than 20, a Monte Carlo test pvalue $<0.05$, and a minimum reduction of five points of stress with the addition of an axis. Two axes were ultimately selected for the scatterplot and output.

\subsection{Results}

\subsubsection{Hydrology}

The water table at the study site varied with seasonal precipitation patterns, being highest in late winter and spring and lowest in late summer to fall (Figure 3.2). Water table heights differed between the undisturbed fen on either side (East or West) of the ditch (Figures 3.2 to 3.6). Prior to restoration, the fen on the west side (up gradient) of the ditch in the central portion of the research site (sector 2) had the slightly higher water table ( 1-2 cm; Figure 3.2). Following ditch restoration in October of 2009, the water table quickly equilibrated between the two sides of the ditch throughout the growing season until late May of 2011, when the water table on the east side rose sharply and remained higher (by $5-10 \mathrm{~cm}$ ) than on the west until the end of monitoring in late July of 2012 (Figure 3.4).

Following replacement of peat spoils into the ditch, Sector 1 had both the highest (west side) and lowest (east side) water tables (relative to soil surface) during the course 
of our sampling and this difference averaged 10-20 cm (Figure 3.3). Sectors 2 and 3 also had discrepancies between the water table heights on the east and west sides, with sector 2 having the east side water table higher by $5-7 \mathrm{~cm}$ (Figure 3.4) and sector 3 having the west side higher by $5-7 \mathrm{~cm}$ (Figure 3.5 ). This difference was particularly pronounced from winter of 2011 through summer of 2012. Sector 4 had the water table roughly equivalent on both sides, with that on the east being slightly higher by $1-2 \mathrm{~cm}$ in the winter and spring (Figure 3.6). These differences were recorded throughout the monitoring period, from May, 2011 through July, 2012. Mean depth to water table values are given in Figure 3.7.

\subsubsection{Pore water Chemistry}

\subsubsection{Dissolved Organic Carbon (DOC)}

Mean DOC levels were similar between the ditch and undisturbed fen samples from fall 2010 through summer 2011 (Figures 3.8 and 3.9; Table 3.1). Overall, levels were slightly higher in the summer samples and lower in the fall (Figure 3.10). Sector 1 had the highest concentrations (mg/L) of DOC from fall 2010 through summer 2011, in both the ditch and undisturbed fen, except for the spring 2011 ditch samples, in which the mean DOC level was somewhat higher in sector 2, although variance made this difference statistically insignificant. Relatively low levels of DOC $(6-45 \mathrm{mg} / \mathrm{L})$ were recorded in most of the undisturbed and ditch samples, although the ditch had elevated levels of DOC (>80 mg/L) in several plots in the November 2010 and May 2011 samples (Figures 3.8 and 3.9, Table 3.1). However, the DOC levels in the ditch were within the 
range of values recorded in the undisturbed fen by July 2011, despite a general increase in average DOC concentrations across all sectors and ditch versus undisturbed fen (Figures 3.9 and 3.10A, Table 3.1). There were no statistically significant differences in overall DOC levels between the restored ditch and undisturbed fen when averaged across the 3 sampling periods, although differences were statistically significant among sectors in both the undisturbed and restored fen (Table 3.2).

\subsubsection{Aromatic Hydrocarbons}

Specific Ultraviolet Absorbance (SUVA 254 ) analysis of our pore water samples found varying amounts of aromatic hydrocarbons among the Sectors and ditch versus restored peatland (Figure 3.8, Table 3.1). Aromatic hydrocarbon levels were weakly correlated with DOC concentrations (Figure 3.8). In November, 2010, the restored ditch had the highest overall mean $\mathrm{SUVA}_{254}$ values (1.66), followed by the west side undisturbed (1.03) and the east (0.93). Within the undisturbed fen, sector 4 had the highest $\mathrm{SUVA}_{254}$ values (1.56), followed by sectors 1 (1.07), 3 (0.97) and 2 (0.32). In the restored ditch, sectors 3 and 4 had the highest mean SUVA $_{254}$ values (2.70 and 2.20, respectively), while those in sectors 1 and 2 were lower (1.11 and 0.63 , respectively).

By May of 2011, SUVA $_{254}$ readings increased (especially in sector 2) and evened out considerably among the sectors and treatments (Figure 3.8, Table 3.1). In the undisturbed fen, sector 4 still had the highest mean values (2.17), but the other three sector means were similar to one another (1.46-1.59; Table 3.1). In the ditch samples, only sectors 1 and 3 had values higher than those in the undisturbed fen (means $=2.13$ 
and 1.84, respectively), while $\mathrm{SUVA}_{254}$ values for sector 2 and 4 samples were less than in the undisturbed fen (Table 3.1). Linear regression of DOC concentration vs SUVA 254 showed moderate correlation between the two across both sampling dates, however, differences among sectors and between undisturbed vs restored fen were statistically insignificant (Table 3.2).

\subsubsection{Metals}

Dissolved metals in the pore water also varied with respect to sector and ditch versus undisturbed peatland during the spring and summer 2011 sampling periods (Table 3.1). Sector 1 had the lowest $\mathrm{Ca}, \mathrm{Fe}, \mathrm{Mn}$ and $\mathrm{Mg}$ levels, in both the restored ditch and undisturbed fen, while sectors 3 and 4 had high concentrations of these elements (Figure 3.11, Table 3.1). Conversely, Sector 1 pore water had the highest concentrations of dissolved $\mathrm{Al}$ and $\mathrm{Zn}$, corresponding with low $\mathrm{pH}$ and electrical conductivity in this sector of the ditch (Table 3.1). Differences among both sectors and treatments (i.e. restored unmulched vs undisturbed fen) were statistically significant for some of these elements (Table 3.2). In both restored and undisturbed fen plots, increases in $\mathrm{Ca}, \mathrm{Mg}$ and $\mathrm{Mn}$ concentration were positively correlated with increases in $\mathrm{pH}$ (Figure 3.11). Overall, mean $2011 \mathrm{Ca}$ and Fe pore water concentrations were similar in both the undisturbed and the restored fen along the length of the ditch (Figure 3.10). 


\subsubsection{Macronutrients}

Across all sectors, $\mathrm{P}$ and $\mathrm{K}$ levels were significantly lower in the undisturbed fen samples ( $0.0-0.1 \mathrm{mg} /$ liter), but were relatively high in many of the disturbed ditch plots $(0.0-1.89 \mathrm{mg} / \mathrm{L} ; 0.2-2.17 \mathrm{mg} / \mathrm{L}$ respectively - Tables 3.1, 3.2). The highest $\mathrm{P}$ concentrations were in the May, 2011 ditch plots in sectors 1 to 3 (Table 3.1), but concentrations dropped to undetectable levels in the vast majority of the summer, 2011 samples (Table 3.1). Low concentrations of TDN $(\sim 1 \mathrm{mg} / \mathrm{L})$ were recorded in November, 2010 from the undisturbed fen, while the ditch samples had high spikes of TDN (>7 mg/L) in several plots (Table 3.1). Differences between restored and undisturbed fen were statistically insignificant (Table 3.2). Levels of TDN were higher in all sectors (both disturbed and undisturbed) in the May and July 2011 samples (Table 3.1). Nitrites were at levels below our detection threshold throughout the course of our study and nitrates didn't appear in detectable concentrations until July of 2011, when they were found in sectors 3 and 4 . Pore water ratios of $C: N, C: P, N: P, K: P$ and Fe:PO4 indicated low dissolved macronutrient concentrations, and many of the differences in nutrients and nutrient ratios were statistically significant among sectors and treatments (Table 3.2). However, 2011 mean levels of N, P and K were similar in the undisturbed and restored fen along the length of the restored ditch, with a few samples having high concentrations of $\mathrm{P}$ and $\mathrm{K}$ in the restored fen (Figure 3.10). 


\subsubsection{Anion/Organic Acid Concentrations}

November 2010 pore water samples contained a number of ionic compounds at relatively low concentrations $(<0.5 \mathrm{ppm}$; Table 3.3). Fluoride, sulfate and oxalate were found in roughly equal amounts in the restored and undisturbed samples while others, like chloride, acetate and propionate, were all found in higher concentration in the restored ditch plots (Table 3.3). Formate was almost completely absent from the undisturbed plots and, in the ditch, occurred primarily in sectors 1 and 2. Phosphate had a peculiar distribution, being found almost exclusively in sector 4, disturbed and undisturbed fen alike (except for an isolated high reading of $1.29 \mathrm{ppm}$ from sector 2: ditch plot 9). Bromide, $\mathrm{NO}_{3}{ }^{-}$and $\mathrm{NO}_{2}{ }^{-}$were completely absent from all samples (both disturbed and undisturbed) in 2010.

By May 2011, the anions and organic acids had shifted in concentration and, in some cases, distribution across our sampling area (Table 3.3). Bromide, nitrite and nitrate remained absent and acetate nearly disappeared from all samples. Formate was gone from the undisturbed fen, but remained present in much of ditch sector 2. Chloride and oxalate concentrations increased 2-4 times across all sampling areas. Phosphate was unrecorded from nearly all of the undisturbed samples (except for sector 1: undisturbed west plot 1) and, in the ditch, was found in measureable quantities only in sectors 1 and 2 . Sulfate remained in similar quantities as in the fall of 2010, but became more localized in distribution, being absent from the undisturbed fen in sector 3 and the east side plots in sector 4 . 
July 2011 samples had anion and organic acid compositions similar to those from May, but with the addition of low amounts of nitrate, especially in the undisturbed fen plots (Table 3.3). Sulfate and chloride concentrations increased somewhat and became more widespread across the sampling plots, both disturbed and undisturbed. Phosphates almost completely disappeared, with just a couple undisturbed plots in sectors 1 and 2 having measureable amounts. Formate became more patchily distributed and nearly disappeared from the ditch plots, while oxalate increased in concentration somewhat and became more widely distributed across all plots. Comparisons of organic acids and anions found no strong correlations between these chemicals and vegetative parameters, with only a few even having $\mathrm{r}^{2}$ values of 0.10 .

\subsubsection{Vegetation}

Variation in forb, grass and bryophyte cover, along with forb and vascular diversity were correlated with gradients in $\mathrm{Ca}, \mathrm{Fe}, \mathrm{Mg}$ and $\mathrm{Mn}$ concentrations along the ditch (Figures 3.12 and 3.13). In the undisturbed fen and restored ditch, grass and forb cover, and forb and vascular plant diversity increased with these parameters, while moss cover (especially cover by Sphagnum spp.) decreased with increases in the concentration of these elements. Conversely, Sphagnum cover increased with increases in $\mathrm{Al}$ and $\mathrm{Zn}$, while vascular diversity, forb diversity and forb and grass cover all decreased with increases in these two elements.

The distribution of several plant species along the ditch line were found to correlate strongly with certain chemical components of the pore water. In particular, the 
calcifilic forbs Campanula aparinoides, Cicuta bulbifera, Doellingeria umbellata, Galium brevipes, Potentilla palustris, Rumex orbiculatus, Scutellaria galericulata, Smilacina trifolia, Solidago uliginosa, Symphyotrichum boreale and Viola macloskeyi were either found exclusively or had their maximum cover values recorded in the high Fe/high Ca/high $\mathrm{pH}$ portions of the fen (Table 3.4). The sedges Carex lasiocarpa and Carex sterilis had similar distributions. This association was most pronounced in the restored ditch (Table 3.4). Conversely, Sphagnum mosses, Carex canescens, $C$. magellanica, C. oligosperma, Chamaedaphne calyculata and Eriophorum virginicum were found only (or primarily) in the low $\mathrm{Fe} /$ low $\mathrm{Ca} / \mathrm{low} \mathrm{pH}$ portions of the study site (Table 3.5).

The NMS ordination showed sorting of the vegetation quadrats among the four sectors and between the restored and undisturbed fen (Figure 3.14). The main differentiation was along Axis 1, representing the scale from poor to rich fen, which was most closely associated with $\mathrm{pH}, \mathrm{Ca}, \mathrm{Fe}, \mathrm{Zn}$ and electrical conductivity, with $\mathrm{Mg}$ and $\mathrm{Mn}$ aligning somewhat with differences between restored and undisturbed vegetation in Sectors 3 and 4 . Vectors for $\mathrm{Ca}$ and Fe clustered tightly with the vector for electrical conductivity along Axis 1. Phosphorous appeared to be strongly aligned with Axis 2, which showed the separation between the restored and undisturbed vegetation. The monocots Dulichium arundinaceum and Eriophorum virginicum appear to be major drivers of plot separation along Axis 2, as they were found only in the restored ditch and were present in most of the plots (especially $D$. arundinaceum). This difference between 
restored and undisturbed fen was also associated with the shrub cover, which was fairly minimal in the restored ditch plots.

\subsection{Discussion}

In fens, disturbance history, hydrology, soils and water chemistry are especially important in shaping restoration planning and determining which plant species can be successfully used in the restoration. These abiotic factors will ultimately determine which plant species germinate, become establish and proliferate. Therefore, prerestoration surveying, sampling and planning is essential to a successful restoration project. In the present study, repeated site visits prior to restoration uncovered rather sharp boundaries in the vegetative composition of the undisturbed fen along the ditch line. Subsequent pore water analysis found these differences to be closely associated with changes in porewater chemistry. We also found there to be seasonal differences in porewater chemistry (Tahvanainen, et al., 2003).

Our NMS ordination shows that differences in vegetative composition were associated with $\mathrm{pH}$ and electrical conductivity gradients along Axis 1, following the classic concept of poor to rich fen (Tahvanainen, 2004). Cover by Sphagnum spp. and Carex oligosperma were closely associated with the poor fen, low $\mathrm{pH}$ end of the gradient. Metals concentrations were also associated with Axis 1, with relatively higher concentrations of $\mathrm{Zn}$ associated with the low $\mathrm{pH}$ end of the spectrum and higher $\mathrm{Ca}, \mathrm{Fe}$, $\mathrm{Mg}$ and $\mathrm{Mn}$ concentrations associated with the rich fen, higher $\mathrm{pH}$ end of the spectrum. Carex magellanica cover was associated with the increasing $\mathrm{Zn}$ gradient, while 
Calamagrostis canadensis cover followed the Mg gradient (along with Campanula aparinoides and Solidago uliginosa). Lysimachia terrestris cover increased with higher $\mathrm{pH}$ and Glyceria canadensis was associated with the higher $\mathrm{pH}$ and $\mathrm{Mn}$ gradients (along with Carex sterilis, C. stricta and Viola macloskeyi). Other fen water studies have found $\mathrm{pH}$, electrical conductivity, $\mathrm{Ca}, \mathrm{Fe}, \mathrm{K}, \mathrm{Mg}^{+}, \mathrm{N}, \mathrm{PO}_{4}$ and ratios such as $\mathrm{N}: \mathrm{P}$ and $\mathrm{Fe}: \mathrm{PO}_{4}$ to be primary determinants of plant species richness and distribution (Cooper and Andrus, 1994; Mullen et al., 2000; Gunnarsson et al., 2000; Bragazza and Gerdol, 2002; Hajkova and Hajek, 2003; Tahvanainen et al., 2004; Mileti et al., 2005; Geurts et al., 2008-2010; Zak et al., 2008; Pawlikowski et al., 2013). As a potential explanation for some of these vegetative differences along $\mathrm{pH}$ gradients, Ström and associates (1994) found that "acidifuge" (= calcifilic) plant species they studied produce relatively large amounts of oxalate and citrate, which allows them to more efficiently solubilize P and Fe, respectively. Conversely, they found that "calcifuge" (= acidophilic) species produce lesser amounts of these acids, which might limit their ability to solubilize $\mathrm{P}$ and $\mathrm{Fe}$, particularly in high $\mathrm{pH}$ environments. We found pore water oxalate levels were fairly even among sectors and restored vs undisturbed plots, so this may not be a limiting factor at our site. Additionally, Crowley and Bedford (2011) found that mosses influence P cycling in rich fens through control of redox conditions and microbial and fungal activity in the upper layers of the peat strata. In our study, P concentrations were similar along the length of the ditch in the spring, 2011 samples but highest in the disturbed ditch. Phosphorous was completely absent from the nearly all of the summer 2011 pore water samples, likely because of uptake by growing plants. 
Along Axis 2, differences were also observed in our data between the undisturbed and restored vegetation and were associated with concentrations of $\mathrm{P}$, which were greater in the restored ditch plots, despite only appearing in the May, 2011 ditch samples and in very low levels $(0.02 \mathrm{mg} / \mathrm{L})$ in the July samples from the undisturbed plots in Sectors 1 and 2. A relatively small number of herbaceous species were strongly defining characteristics for vegetation in the restored ditch, particularly the presence and cover by Dulichium arundinaceum and Eriophorum virginicum, which were completely absent from the undisturbed vegetation plots and were included in the seed mix used in restoration. Dulichium is of particular interest as it was a fairly small component of the seed mix yet provided substantial cover in all sectors, especially 3 and 4 . It also appeared in the unplanted control plots, so must have been present in the local seed bank. The only place where it was found growing locally was a disturbed portion of the fen along a firebreak ca. $1 \mathrm{~km}$ away from the restoration site, where peat had been scraped away, exposing the underlying mucky sand. Here it co-occurred with other species rarely observed at the fen complex, such as Agalinis purpurea, Drosera intermedia and Scheuchzeria palustris. This suggests that seed present in the seed bank at our restoration site were likely quite old, possibly several hundred to a few thousand years in age. Eriophorum virginicum occurred in the nearby unburned fen and it is assumed it was previously present in the burned area but was eliminated from the local flora when the upper peat layer was burned off during the wildfire, taking the shallowly rooted $E$. virginicum rhizomes with it. Symphyotrichum boreale and Carex lasiocarpa were strong factors defining the undisturbed plots in Sectors 3 and 4 and S. boreale was absent from 
the restored ditch plots, despite being included in our seed mix. Carex lasiocarpa also occurred in the restored ditch, but at lesser cover values. The lack of shrub cover in the restored ditch was also apparently a factor driving the separation of the restored and undisturbed sites along Axis 2 in our NMS analysis.

Given the relatively undisturbed nature of our site and its surroundings, along with the lack of agriculture in the general vicinity, water chemistry analysis showed no large imbalance in macronutrient concentrations as is often the case in disturbed, temperate zone fens surrounded by heavily human-altered landscapes (Wassen and Barendgregt, 1992, Rozbrojová and Hajek, 2008, Geurts et al., 2008-2010, Hettenbergerová et al., 2013). Our results show that pre- and post-restoration vegetation and water sampling should occur over the entire restoration site, whenever possible, as what may superficially appear to be a homogeneous region can have sharply defined changes in abiotic parameters which will, in turn, limit the plant species that can be established during restoration. Our study also shows that it is important to look at multiple pore water parameters, as a site's chemical complexity may not be revealed if only $\mathrm{pH}$ or electrical conductivity is measured. It is also important to be careful about extrapolating methods and results from other studies as sites vary greatly in geography and chemistry, thus requiring site-specific methodology based on the results of your initial investigative surveys and sampling.

As an example, Snowden and Wheeler (1993) found that growth of several British fen forbs was negatively affected by the presence of dissolved iron (i.e. the plants expressed "iron toxicity") even at relatively low concentrations $(10-25 \mathrm{mg} / \mathrm{L})$, 
compared to our results. In contrast, we found the exact opposite, with most of our forb species occurring only in the high iron plots $(6-50 \mathrm{mg} / \mathrm{L})$, including ones closely related to those in the British study. In particular, the forbs Campanula aparinoides, Cicuta bulbifera, Doellingeria umbellata, Galium brevipes, Potentilla palustris, Rumex orbiculatus, Scutellaria galericulata, Smilacina trifolia, Solidago uliginosa, Symphyotrichum boreale and Viola macloskeyi were either found exclusively or had their maximum cover values recorded in the high iron portions of the fen. This association was most pronounced in the restored ditch (Table 3.4).

Iron-rich fens are apparently quite diverse, in terms of water chemistry, ranging from acidic sites with little in the way of buffering agents such as $\mathrm{Ca}$ and $\mathrm{Mg}$ (Chimner et al., 2010, Reiche et al.,2008, Hájková and Hájek, 2004, Tahvanainen, 2003) to those like the Sleeper Lake Fen in which high iron levels are accompanied by circumneutral $\mathrm{pH}$ and relatively high concentrations of these elements (Fleming et al., 2014, Vollrath, 2012, Zou et al., 2011, Wang, 2011, Haaijer et al., 2008, Emerson and Weiss, 2004, Johnson and Steingraeber, 2003, Bendell-Young, 1999). It is probable that $\mathrm{Ca}$ and $\mathrm{Mg}$ carbonates are causing the higher $\mathrm{pH}$ readings for our site, which may have buffered the effects of iron toxicity on forb growth, as alluded to by Snowden and Wheeler (1993). We believe our observed difference in iron effects is due to the perennially high water table, sheet flow of surface water throughout much of the growing season and complex water chemistry at Sleeper Lake Fen, where high $\mathrm{pH}, \mathrm{Ca}$ and $\mathrm{Mg}$ levels are coupled with similarly high levels of dissolved iron. This is supported by the research of Aggenbach et al. (2013) who found high levels of Fe accumulation in drained fens in the Netherlands, 
concluding that high concentrations of this metal had an inhibiting effect on fen plant growth following hydrologic restoration, which was compounded by the loss of $\mathrm{Ca}$ and Mg through drainage-related redox and leaching. However, it should be noted that their iron levels were orders of magnitude greater than any we recorded for the Sleeper Lake Fen restoration site.

Both our study and that of Snowden and Wheeler (1993) found that monocots do well under high iron conditions. Snowden and Wheeler thought this was related to a "superior oxidative-detoxification system" although they did not elaborate on just what such a system might be. They may have been referring to the ability of many wetland monocots to use "channels" of aerenchyma tissue to draw air (especially O2) from their leaves down to their root zone for respiration during periods of inundation. Snowden and Wheeler also believed that monocots dominated in such conditions because of a generally slower growth rate; however the monocots in our study were observed to grow much faster than associated dicots and quickly dominated all of our sampling plots. We also found calciphilic sedges such as Carex lasiocarpa and C. sterilis dominating the sedge fauna in our high iron/calcium plots but were absent from the lower $\mathrm{pH}$ plots (those with $\mathrm{pH}$ values less than 5.5). Acidophilic sedges such as Carex magellanica, C. oligosperma and Eriophorum virginicum were absent from the high iron/high $\mathrm{pH}$ portion of our study site, despite their inclusion in the seed mix used in our restoration.

Dissolved organic carbon (DOC), composed of carbohydrates, peptides, organic acids, alcohols and similar chemicals (Sachse et al., 2005) less than $0.45 \mu \mathrm{m}$ in length, is one of the most biologically important components of peatland water. In peatlands that 
discharge into adjacent aquatic systems, DOC provides the basic building sectors for aquatic food webs and can responsible for a large portion (4-8\%) of primary production in these systems (Kolka et al., 2008). The production, cycling, discharge and decomposition of DOC is dependent upon a number of factors, especially hydrology (Schiff et al., 1998), moisture (Kane et al., 2010), temperature (Koehler et al., 2009; Preston et al., 2011) and peat composition or quality (Laiho et al., 2003; Wickland et al., 2007, Armstrong et al., 2012). In diked or ditched and drained peatlands, DOC cycling and discharge are interrupted (Hribljan et al., 2014). Restoration (especially re-wetting) of degraded peatlands is known to increase production of DOC, often for extended periods following restoration (van Dijk et al., 2004, Laine et al., 2006). Webster and McLaughlin (2010) associated DOC concentrations with fen hydrology in the northern Lake Superior Basin of Ontario, positing that increased DOC concentrations decrease along the fen $\mathrm{pH}$ continuum, from poor to rich, with rich fens having higher water tables and low concentrations of DOC. Their undisturbed rich fen sites had $\sim 13 \mathrm{mg}$ DOC/L averaged across 4 growing seasons (2005-2008), compared to our undisturbed DOC averages of $34 \mathrm{mg} / \mathrm{L}$ averaged across the 2010-2011 sampling period. The DOC levels in our restored ditch were nearly identical at $35 \mathrm{mg} / \mathrm{L}$ for the same sampling period. In contrast, Höll et al. (2009) recorded mean DOC levels much higher than ours, with $50 \mathrm{mg} / \mathrm{L}$ and $66 \mathrm{mg} / \mathrm{L}$, respectively, in their comparison of a long-rewetted (20 years) and moderately drained fen in southern Germany. The comparatively low level of DOC in both our undisturbed and restored fen plots likely was a result of the pristine nature of the 
fen complex and its surrounding uplands, the perennially high water table and relative youth of the re-wetted peat.

In our study, peat was excavated from the ditch and placed as a berm on one side, where it dried for 2 years prior to replacement. Peat replacement into the ditch resulted in a slurry of finely shredded sedge peat, chunks of consolidated peat and wood. The levels of DOC in the ditch were initially higher than in the undisturbed fen following restoration in 2010, likely the result of initial leaching of DOC from the partially decomposed peat. However, by July of 2011, DOC levels had essentially equilibrated between the restored and undisturbed fen (Figures 3.9 and 3.10). The 2011 data also gave some indication of DOC transport out of the ditch in Sectors 2 and 4, where DOC levels were higher on the east (down flow) side of the ditch than the west (up flow). Organic acids are also often found in elevated concentrations in restored fens, although our data were inconclusive. Fluoride, chloride and oxalate concentrations increased over the course of our study, but this occurred in both the ditch and the undisturbed fen and the increases in oxalate were likely due to increased plant and microbial productivity (Lane, 1994, Ström et al., 1994).

Throughout the course of this study, DOC levels were highest in Sector 1, in both the restored ditch and the adjacent, undisturbed fen (Table 1). This was probably because sheet flow of surface water in this sector was limited by low sand dunes that cut the area off from the rest of the fen, allowing DOC levels to build up over time. The dense cover of Sphagnum mosses in this portion of the fen may have also added to the DOC through production of carbonaceous photosynthates, although shifts to cover by vascular plants 
can increase DOC production through introduction of additional carbon inputs, like root exudates or litter accumulation, or manipulation of the water table through increased evapotranspiration (Fenner et al., 2009). Vestgarden et al. (2010) found similar gradients in DOC, with Sphagnum-dominated, acidic mires having higher DOC concentrations at the 20-30 cm depth than those dominated by other acidic moorland/mire species such as Calluna (heather) or Molina caruleae (moor grass). Their mean DOC concentrations $(<10 \mathrm{mg} / \mathrm{L})$ were well below ours $(\sim 34 \mathrm{mg} / \mathrm{L})$ and these differences are likely a reflection of variation in site hydrology, primary productivity and peat composition. The fairly rapid equilibration of DOC levels in the undisturbed and restored fen across our study site was likely due to a combination of factors, such as the short time period that the peat remained dry and oxidized (2 years), the sheet flow of large volumes of water through the site and the perennially high water table. The high water table limits aerobic microbial decomposition of the peat and thus the production of DOC.

\subsection{Implications for Practice}

Our data suggest a strong association between plant species distribution/cover and water chemistry at Sleeper Lake Fen. Water chemistry was also shown to have a strong influence on which species germinated, established and proliferated in our restored plots, even over the short period of time that we sampled (2 years post-restoration; Bess et al., 2014). Therefore, we believe an understanding of site water chemistry (especially pH, electrical conductivity, macro-nutrient, $\mathrm{Ca}$ and Fe concentrations) is essential to developing a successful fen restoration project. 
In particular, the occurrence of the most diverse flora in the most iron-rich portion of our site was a surprise and runs counter to the published information on iron and fen vegetation (Snowden and Wheeler, 1993, Aggenbach et al., 2013). The co-occurrence of relatively high iron, $\mathrm{Ca}$ and TDN levels with low $\mathrm{P}$ (coupled with the most diverse and dense cover of forbs) is also in opposition to much of the published information on fen vegetation (Boeye, et al., 1997; Wassen and Barendregt, 1992; Mullen et al., 2000; Olde Venterink et al., 2001; Hajkova and Hajek, 2003; Rozbrojová and Hajek, 2008; Geurts et al., 2008-2010; Zak et al., 2008-2009; Crowley and Bedford, 2011; Hettenbergerova et al., 2013; Pawlikowski et al., 2013), further supporting the importance of understanding site water chemistry when developing peatland restoration programs.

On sites with remnant vegetation, plant species composition can be used as a proxy for pore water chemistry and seed or nursery stock mixes used in restoration should closely mimic the existing vegetation. However, in completely denuded, prior mined or agricultural sites, understanding porewater chemistry will be crucial to the success of a restoration project. Most wetland plants have narrow ranges of tolerances for various soil/porewater parameters such as $\mathrm{pH}$ and calcium or iron concentration. High levels of macronutrients like N, P or K favor the growth of non-native and weedy invasive species like reed canarygrass or hybrid cattails, species whose occurrence and proliferation can be serious obstacles to successful natural area restoration. In addition, many native peatland plant species will simply not grow or are quickly outcompeted once certain nutrient concentration thresholds are crossed (Glaser et al., 1990; Gignac et al., 1991; Bedford et al., 1999; Hajkova and Hajek, 2003-2004). 
Inexpensive $\mathrm{pH}$ kits can be purchased to provide basic information on porewater acidity/alkalinity and relatively inexpensive meters can be purchased to accurately sample for electrical conductivity and total dissolved solids (US\$40.99 - HM Digital COM-80 HydroTester EC/TDS Meter at www.marinedepot.com), calcium concentration (US\$49.00 HI758 Marine Calcium Checker® HC at www.hannainst.com) or iron concentration (\$58.39 HACH Iron Color Disc Test Kit, Model IR-18B at www.hach.com). Information on soil (peat) organic matter, nitrogen, phosphorus and potassium can be obtained from local USDA extension offices or, for water samples, through local universities with photospectrometers (typically US\$1.00/element/sample).

\subsection{Acknowledgements}

Funding for this research was provided by The Nature Conservancy, Michigan DNR and the U.S. EPA: Great Lakes Restoration Initiative. The Nature Conservancy also provided us with maps, results of previous botanical surveys and on-site lodging. Laura Kangas provided invaluable assistance in collecting seeds, setting up the experimental design and collecting initial vegetation data. We would also like to thank Jennifer Eikenberry for analyzing our many water samples and Dr. Andrew Burton for allowing the use of his lab's Photospectrometer and other equipment. The U. S. Forest Service also allowed us use of their Houghton laboratory and equipment. Tamara Baker assisted in collecting 2011 vegetation data, while Jennifer Bush and Erin Grupido assisted with pore water sampling and computer data input. 


\subsection{Literature Cited}

Aggenbach C., H. Backx, W. Emsens, A. Grootjans, L. Lamers, A. Smolders, P. Stuyfzand, L. Wołejko and R. Van Diggelen. (2013): Do high iron concentrations in rewetted rich fens hamper restoration? Preslia 85: 405-420.

Andersen, R., A-J. Francez and L. Rochefort. 2006. The physiochemical and microbiological status of a restored bog in Quebec: Identification of relevant criteria to monitor success. Soil Biology and Biochemistry 38: 1375-1387.

Anshaari, G., M. Afifudin, M. Nuriman, E. Gusmayanti, L Ariane, R. Susana, R. Nusantara, J. Sugardjito and A. Rafiastanto. 2010. Drainage and land use impacts on changes in selected peat properties and peat degradation in western Kalimantan Province, Indonesia. Biogeosciences 7:3403-3419

Armstrong, A., J. Holden, K. Luxton and J. Quinton. 2012. Multi-scale relationship between peatland vegetation type and dissolved organic carbon concentration. Ecological Engineering 47: 182-188.

Bedford, B., M. Walbridge, A. Aldous. 1999. Patterns in nutrient availability and plant diversity of temperate North American wetlands. Ecology 80:2151-2169

Beltman, B., T. van der Broek, K. van Maanen and K. Vaneveld. 1996. Measures to develop a rich-fen wetland landscape with a full range of successional stages. Ecological Engineering 7: 299-313.

Bendell-Young, L. 1999. Contrasting the sorption of Zn by oxyhydroxides of Mn and $\mathrm{Fe}$, and organic matter along a mineral-poor to mineral-rich fen gradient. Applied Geochemistry 14: 719-734. 
Bess, J., R. Chimner and L. Kangas. 2014. Ditch Restoration in a Large Northern Michigan Fen: Vegetation Response and Basic Porewater Chemistry. Ecological Restoration 32(3): 260-274. ISSN 1522-4740 E-ISSN 1543-4079.

Boelter, D. 1972. Water table drawdown around an open ditch in organic soils. Journal of Hydrology 15:329-340.

Boeye, D., B. Verhagen, V. Van Haesebroeck and R. Verheyen. 1997. Nutrient limitation in species-rich lowland fens. Journal of Vegetation Science 8: 415-424.

Bragazza, L. and R. Gerdol. 2002. Are nutrient availability and acidity-alkalinity gradients related in Sphagnum-dominated peatlands? Journal of Vegetation Science 13: 473-482.

Chimner, R., J. Lemly and D. Cooper. 2010. Mountain Fen Distribution, Types and Restoration Priorities, San Juan Mountains, Colorado, USA. Wetlands 30:763771.

Clewell, A., J. Rieger and J. Munro. 2005. Guidelines for developing and managing restoration projects, $2^{\text {nd }}$ edition. Society for Ecological Restoration International. 16 pages.

Cobbaert, D, L. Rochefort and J. Price. 2004. Experimental restoration of a fen plant community after peat mining. Applied Vegetation Science 7:209-220.

Cohen, J., D. Albert, M. Kost, and B. Slaughter. 2010. Natural community abstract for coastal fen. Michigan Natural Features Inventory, Lansing, MI. 16 pp. www. mnfi.anr.msu.edu/abstracts/ecology/coastal_fen.pdf. 
Cohen, J. and M. Kost. 2008. Natural community abstract for northern fen. Michigan Natural Features Inventory, Lansing, MI. 19 pp. www.mnfi.anr.msu.edu/abstracts/ecology/Northern_Fen.pdf.

Cooper, D. and R. Andrus. 1994. Patterns of vegetation and water chemistry in peatlands of the west-central Wind River Range, Wyoming, U.S.A. Canadian Journal of Botany 72: 1586-1597.

Crowley, K. and B. Bedford. 2011. Mosses influence phosphorous cycling in rich fens by driving redox conditions in shallow soils. Oecologia 167: 253-264.

De Mars, H., M. Wassen and W. Peeters. 1996. The effect of drainage and management on peat chemistry and nutrient deficiency in the former Jegrzinga-floodplain (NE Poland). Vegetatio 126:59-72

Emerson, D. and J. Weiss. 2004. Bacterial Iron Oxidation in Circumneutral Freshwater Habitats: Findings from the Field and the Laboratory. Geomicrobiology Journal 21: 405-414.

Fenner, N., C. Freeman and F.Worrall. 2009. Hydrological Controls on Dissolved Organic Carbon Production and Release From UK Peatlands. Carbon Cycling in Northern Peatlands: Geophysical Monograph Series 184: 237-249.

Fisher, A., G. Podniesinski and D. Leopold. 1996. Effects of drainage ditches on vegetation patterns in abandoned agricultural peatlands in central New York. Wetlands 16(4): 397-409. 
Fleming, E., I. Cetinic, C. Chan, D. Whitney King4 and D. Emerson. 2014. Ecological succession among iron-oxidizing bacteria. International Society for Microbial Ecology Journal 8: 804-815.

Geurts, J., A. Smolders, J. Verhoeven, J. Roelofs and L. Lamers. 2008. Sediment Fe:PO4 ratio as a diagnostic and prognostic tool for the restoration of macrophyte biodiversity in fen waters. Freshwater Biology 53: 2101-2116.

Geurts, J., A. Smolders, A. Banach, J. van de Graaf, J. Roelofs and L. Lamers. 2010. The interaction between decomposition, net $\mathrm{N}$ and $\mathrm{P}$ mineralization and their mobilization to the surface water in fens. Water Research 44: 3487-3495.

Gignac, L.D., D.H. Vitt, S.C. Zoltai, and S.E. Bayley. 1991. Bryophyte response surfaces along climatic, chemical, and physical gradients in peatlands of western Canada. Nova Hedwigia 53: 27-71.

Glaser, P.H., J.A. Janssens, and D.I. Siegel. 1990. The response of vegetation to chemical and hydrological gradients in the Lost River Peatland, northern Minnesota. Journal of Ecology 78: 1021-1048.

Grootjans, A. and R. van Diggelen. 1995. Assessing the restoration prospects of degraded fens. Pages 73-90 in Wheeler, B., S. Shaw, W. Fojt and R. Robertson, editors. Restoration of Temperate Wetlands. J. Wiley and Sins, Ltd., Chichester, United Kingdom.

Gunnarsson, U., H. Rydin, and H. Sjörs. 2000. Diversity and pH changes after 50 years on the boreal mire Skattlösbergs Stormosse, central Sweden. Journal of Vegetation Science 11: 277-286. 
Haaijer, S., H. Harhangi, B. Meijerink, M. Strous, A. Smolders, K. Verwegen, M. Jetten and H. DenCamp. 2008. Bacteria associated with iron seeps in a sulfur-rich, neutral $\mathrm{pH}$, fresh water ecosystem. International Society for Microbial Ecology Journal 2: 1231-1242.

Hájková, P. and M. Hájek. 2004. Bryophyte and Vascular Plant Responses to BaseRichness and Water Level Gradients in Western Carpathian Sphagnum-Rich Mires. Folia Geobotanica 39(4): 335-351.

Hájková, P. and M. Hájek. 2003. Species richness and above-ground biomass of poor and calcareous spring fens in the flysch West Carpathians and their relationship to water and soil chemistry. Preslia, Praha 75:271-287.

Hald, A. and E. Vinther. 2000. Restoration of a species-rich fen-meadow after abandonment: response of 64 plan species to management. Applied Vegetation Science 3: 15-24.

Hettenbergerova, E., M. Hájek D. Zelený, J. Jiroušková and E. Mikulášková. 2013. Changes in species richness and species composition of vascular plants and bryophytes along a moisture gradient. Preslia 85: 369-388.

Höll, B., S. Fiedler, H. Jungkunst, K. Kalbitz, A. Freibauer, M. Drösler and K. Stahr. 2009. Characteristics of dissolved organic matter following 20 years of peatland restoration. Science of the Total Environment 408: 78-83.

Hribljan, J., E. Kane, T. Pypker and R. Chimner. 2014. The effect of long-term water table manipulations on dissolved organic carbon dynamics in a poor fen peatland. Journal of Geophysical Research: Biogeosciences 119: 577-595. 
Jansen, A., L. Fresco, A. Grootjans and M. Jalink. 2004. Effects of restoration measures on plant communities of wet heathland ecosystems. Applied Vegetation Science 7: $243-252$.

Johnson, J. and D. Steingraeber. 2003. The vegetation and ecological gradients of calcareous mires in the South Park valley, Colorado. Canadian Journal of Botany 81: 201-219.

Joosten, H. and D. Clarke. 2002. Wise use of mires and peatlands - Background and principles including a framework for decision making. International Mire Conservation Group, International Peat Society, Geifswald.

Kane, E., M. Turetsky, J. Harden, A. McGuire and J. Waddington. 2010. Seasonal ice and hydrologic controls on dissolved organic carbon and nitrogen concentrations in a boreal-rich fen. Journal of Geophysical Research 115: G04012.

Klimkowska, A., R.VanDiggelen, A.Grootjans and W. Kotowski. 2010. Prospects for fen meadow restoration on severely degraded fens. Perspectives in Plant Ecology, Evolution and Systematics 12: 245-255.

Koehler, A., K. Murphy, G. Kiely and M. Sottocornola. 2009. Seasonal variation of DOC concentration and annual loss of DOC from an Atlantic blanket bog in South Western Ireland. Biogeochemistry 95(2-3): 231-242.

Kolka, R, P. Weisbarnpel and M. Froberg. 2008. Measurement and importance of dissolved organic carbon. Chapter 13 In: Field Measurements for Forest Carbon. Monitoring (C.M. Hoover (ed.)), Springer Science Business Media B.V. 
Laiho, R., H. Vasander, T. Penttilä and J. Laine. 2003. Dynamics of plant-mediated organic matter and nutrient cycling following water-level drawdown in boreal peatlands. Global Biogeochemical Cycles 17(2): 1053.

Laine, J., R. Laiho, K. Minkkinen and H. Vasander. 2006. Forestry and Boreal Peatlands. In: Boreal Peatland Ecosystems (R. Weider and D. Vitt, Eds.). Ecological Studies volume 188.

Lamers, L., M. Vile, A. Grootjans, M. Acreman, R. van Diggelen, M. Evans, C. Richardson, L. Rochefort, A. Kooijman, J. Roelofs and A. Smolders. 2015. Ecological restoration of rich fens in Europe and North America: from trial and error to an evidence-based approach. Biological Reviews 90: 182-203.

Lane, B. 1994. Oxalate, germin and the extracellular matrix. The Federation of American Societies for Experimental Biology Journal 8: 294-301.

Large, A. 2001. Reversing spontaneous succession to protect high-value vegetation: Assessment of two Scottish mires using rapid survey techniques. Applied Vegetation Science 4: 103-110.

Levia, D. and D. Carlyle-Moses. 2011. Forest Hydrology and Biogeochemistry: Synthesis of Past Research and Future Directions. Ecological Studies 216. 740 pages.

Lode, E. 1999. Wetland restoration: a survey of options for restoring peatlands. Studia Forestalia Suecica no. 205. Swedish University of Agricultural Sciences. Uppsala, Sweden. 
Mileti, T., C. Caryle, C. Picard, K. Mulac, A. Landaw and L. Fraser. 2005. Hydrology, water chemistry and vegetation characteristics of a tamarack bog in bath township, Ohio: Towards restoration and enhancement. Ohio Journal of Science 105: 21-30.

Mullen, S., J. Janssens and E. Gorham. 2000. Acidity of and the concentrations of major and minor metals in the surface water of bryophyte assemblages from 20 North American bogs and fens. Canadian Journal of Botany 78: 718-727.

Olde Venterink, H., R. van der Vliet and M. Wassen. 2001. Nutrient limitation along a productivity gradient in wet meadows. Plant and Soil 234: 171-179.

Page, S., A. Hoscilo, H. Wosten, J. Jauhiainen, M. Silvius, J. Rieley, H. Ritzema, K. Tansey, L. Graham, H. Vasander and S. Limin. 2009. Restoration ecology of lowland tropical peatlands in Southeast Asia - Current knowledge and future research directions. Ecosystems 12: 888-905.

Patzelt, A., U. Wild and J. Pfadenhauer. 2001. Restoration of wet fen meadows by topsoil removal: vegetation development and germination biology of fen species. Restoration Ecology 9(2): 127-136.

Pawlikowski, P., K. Abramczyk, A. Szzepaniuk and L. Kozub. 2013. Nitrogen: phosphorous ratio as the main ecological determinant of the differences in the species composition of brown-moss rich fens in north-eastern Poland. Preslia 85: 349-367.

Preston, M., M. Eimers and S.Watmough. 2011. Effect of moisture and temperature variation on DOC release from a peatland: Conflicting results from laboratory, 
field and historical data analysis. Science of the Total Environment 409(7): 12351242.

Price, J., A. Heathwaite and A. Baird. 2003. Hydrological processes in abandoned and restored peatlands; an overview of management approaches. Wetlands Ecology and Management 11(1-2): 65-83.

Reiche, M., G. Torburg and K. Küsel. 2008. Competition of Fe(III) reduction and methanogenesis in an acidic fen. Federation of European Microbiological Societies, Microbiological Ecology 65: 88-101.

Rozbrojová, Z. and M. Hájek. 2008. Changes in nutrient limitation of spring fen vegetation along environmental gradients in the West Carpathians. Journal of Vegetation Science 19: 613-620.

Rydin, H. and J. Jeglum. 2006. The Biology of Peatlands. Oxford University Press, 343 pages.

Sachse, A., R. Henrion, J. Gelbrecht and C. Steinberg. 2005. Classification of dissolved organic carbon (DOC) in river systems: Influence of catchment characteristics and autochthonous processes. Organic Geochemistry 36(6): 923-935.

Schiff, S., R. Aravena, E. Mewhinney, R. Elgood, B. Warner, P. Dillon, S. Trumbore. 1998. Precambrian shield wetlands: hydrologic control of the sources and export of dissolved organic matter. Climate Change 40: 167-188.

Snowden, R. and B. Wheeler. 1993. Iron toxicity to fen plant species. Journal of Ecology 81:35-46 
Soomers, H., D. Karssenberg, J. Verhoeven, P. Verweij and M. Wassen. The effect of habitat fragmentation and abiotic factors on fen plant occurrence. Biodiversity Conservation 22:405-424.

Ström, L., T. Olsson and G. Tyler. 1994. Differences between calcifuge and acidifuge plants in root exudation of low molecular acids. Plant and Soil 67: 239-245.

Tahvanainen, T. 2004. Water chemistry of mires in relation to the poor-rich vegetation gradient and contrasting geochemical zones of the northeastern Fennoscandian Shield. Folia Geobotanica 39:353-369.

Tahvanainen, T., T. Sallantaus, and R. Heikkilä. 2003. Seasonal variation of water chemical gradients in three boreal fens. Annales Botanici Fennici 40: 345- 355.

Trepel, M. 2007. Evaluation of the implementation of a goal-oriented peatland rehabilitation plan. Ecological Engineering 30:167-175.

USDA, NRCS. 2012a. Soil Survey for Luce County, Michigan. NRCS Soils Website. USDA, NRCS, Washington, D.C. Available: http://soils.usda.gov/. (Accessed: January 21, 2012).

USDA, NRCS. 2012b. The PLANTS Database (http://plants.usda.gov, 15 August 2012). National Plant Data Team, Greensboro, NC 27401-4901 USA.

USEPA. 2013. SESD Operating Procedure: Pore Water Sampling. SESDPROC-513R2, Pore Water Sampling (513)_AF. R2. U. S. Environmental Protection Agency: Region 4, Science and Ecosystem Support Division. Athens, GA. van Dijk, J., M. Stroetenga, L. Bos, P. Bodegom, H. Verhoef and R. Aerts. 2004. Restoring natural seepage conditions on former agricultural grasslands does not 
lead to reduction of organic matter decomposition and soil nutrient dynamics. Biogeochemistry 71:317-337.

van Duren, I., D. Boeye and A. Grootjans. 1997. Nutrient limitations in an extant and drained poor fen: implications for restoration. Plant Ecology 133: 91-100.

Van Duren, I., R. Strykstra, A. Grootjans, G. ter Heerdt and D. Pegtel. 1998. A multidisciplinary evaluation of restoration measures in a degraded CirsioMolentinum fen meadow. Applied Vegetation Science 1: 115-130.

Vestgarden, L., K. Austnes and L. Strand. 2010. Vegetation control on DOC, DON and DIN concentrations in soil water from a montane system, southern Norway. Boreal Environment Research 15:565-578.

Vollrath, S. 2012. Microbial Fe(II) oxidation at circumneutral pH: reaction kinetics, mineral products and distribution of neutrophilic iron oxidizers in wetland soils. Thesis: Utrecht Studies in Earth Sciences No. 009. Utrecht University ISBN 97890-6266-290-6.

Voss, E. 1996. Michigan Flora: Dicots (Pyrolaceae-Compositae). Cranbrook Institute of Science.

Voss, E. 1985. Michigan Flora: Dicots (Saururaceae-Cornaceae). Cranbrook Institute of Science.

Voss, E. 1972. Michigan Flora: Gymnosperms and monocots. Cranbrook Institute of Science.

Voss, E. and A. Reznicek. 2012. Field Manual of Michigan Flora. The University of Michigan Press, Ann Arbor, Michigan. 990 pages. 
Wang, J. 2011. Ecology of neutrophilic iron-oxidizing bacteria in wetland soils. PhD thesis, Utrecht University, Science Faculty. NIOO thesis 84. ISBN: 978-90-39354940.

Wassen, M. and A. Barendregt. 1992. Topographic position and water chemistry of fens in a Dutch river plain. Journal of Vegetation Science 3: 447-456.

Webster, K. and J. McLaughlin. 2010. Importance of the water table in controlling dissolved carbon along a fen nutrient gradient. Soil Science Society of America Journal 74(6): 2254-2265.

Weishaar, J., G. Aiken, B. Bergamaschi , M. Fram, R. Fujii and K. Mopper. 2003. Evaluation of specific ultraviolet absorbance as an indicator of the chemical composition and reactivity of dissolved organic carbon. Environmental Science and Technology 37: 4702-4708.

Wickland, K., J. Neff and G. Aiken. 2007. Dissolved organic carbon in Alaskan boreal forest: Sources, chemical characteristics and biodegradability. Ecosystems 10(8): $1323-1340$.

Zak, D., T. Rossoll, H. Exner, C. Wagner and J. Galbrecht. 2009. Mitigation of sulfate pollution by rewetting of fens - a conflict with restoring their phosphorous sink function? Wetlands 29(4): 1093-1103.

Zak, D., J. Gelbrecht, C. Wagner and C. Steinberg. 2008. Evaluation of phosphorous mobilization potential in rewetted fens by an improved sequential chemical extraction procedure. European Journal of Soil Science 59: 1191-1201. 
Zou, Y., M. Jiang, X. Yu, X. Lu, J. David and H. Wu. 2011. Distribution and biological cycle of iron in freshwater peatlands of Sanjiang Plain, Northeast China. Geoderma 164: 238-248. 


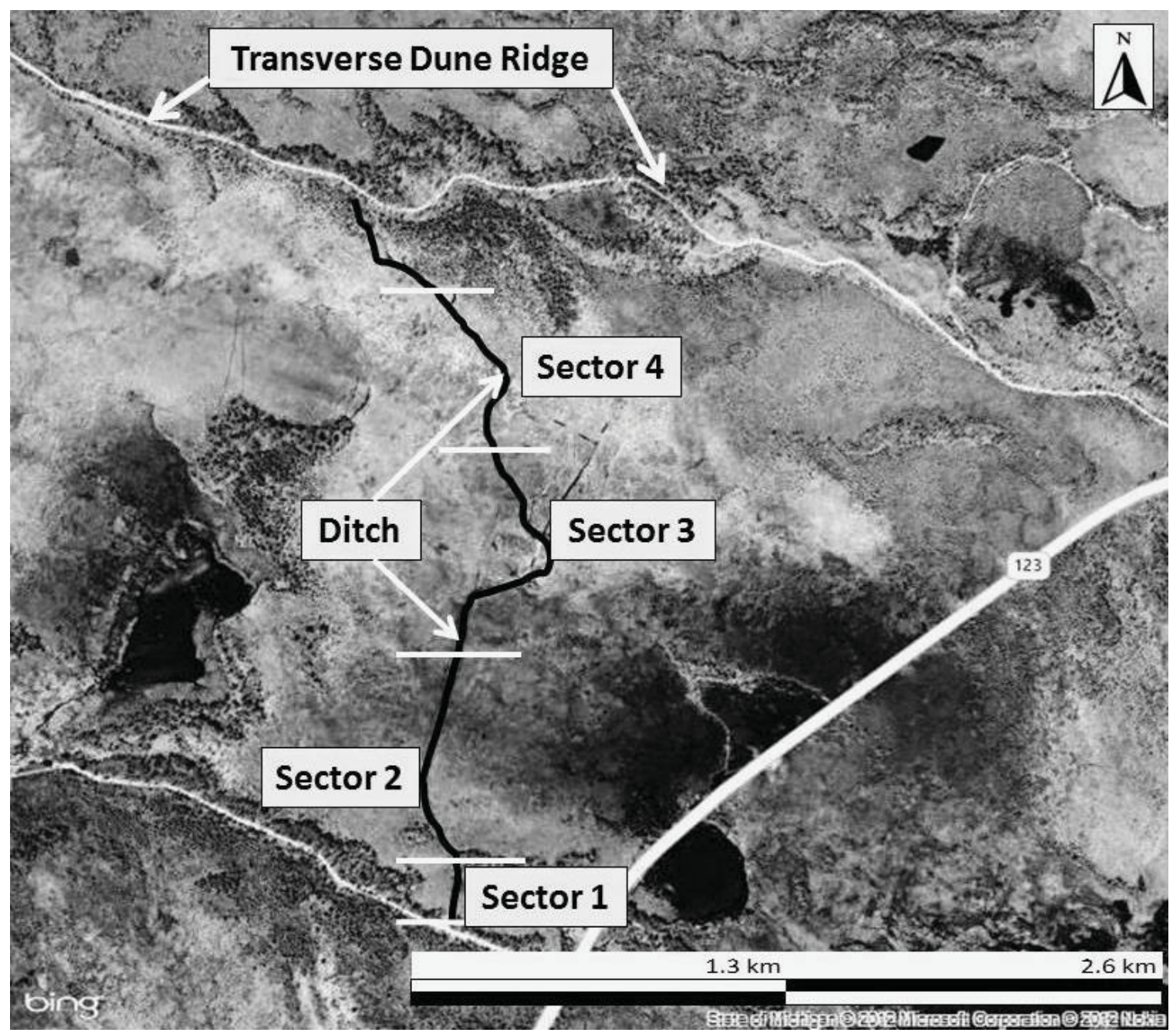

Figure 3.1. The Sleeper Lake Fen restoration site showing location of ditch, dune ridge and sampling sectors. Source: "Sleeper Lake Fen." Bing Maps, Microsoft, Inc. Accessed September 20, 2012. 


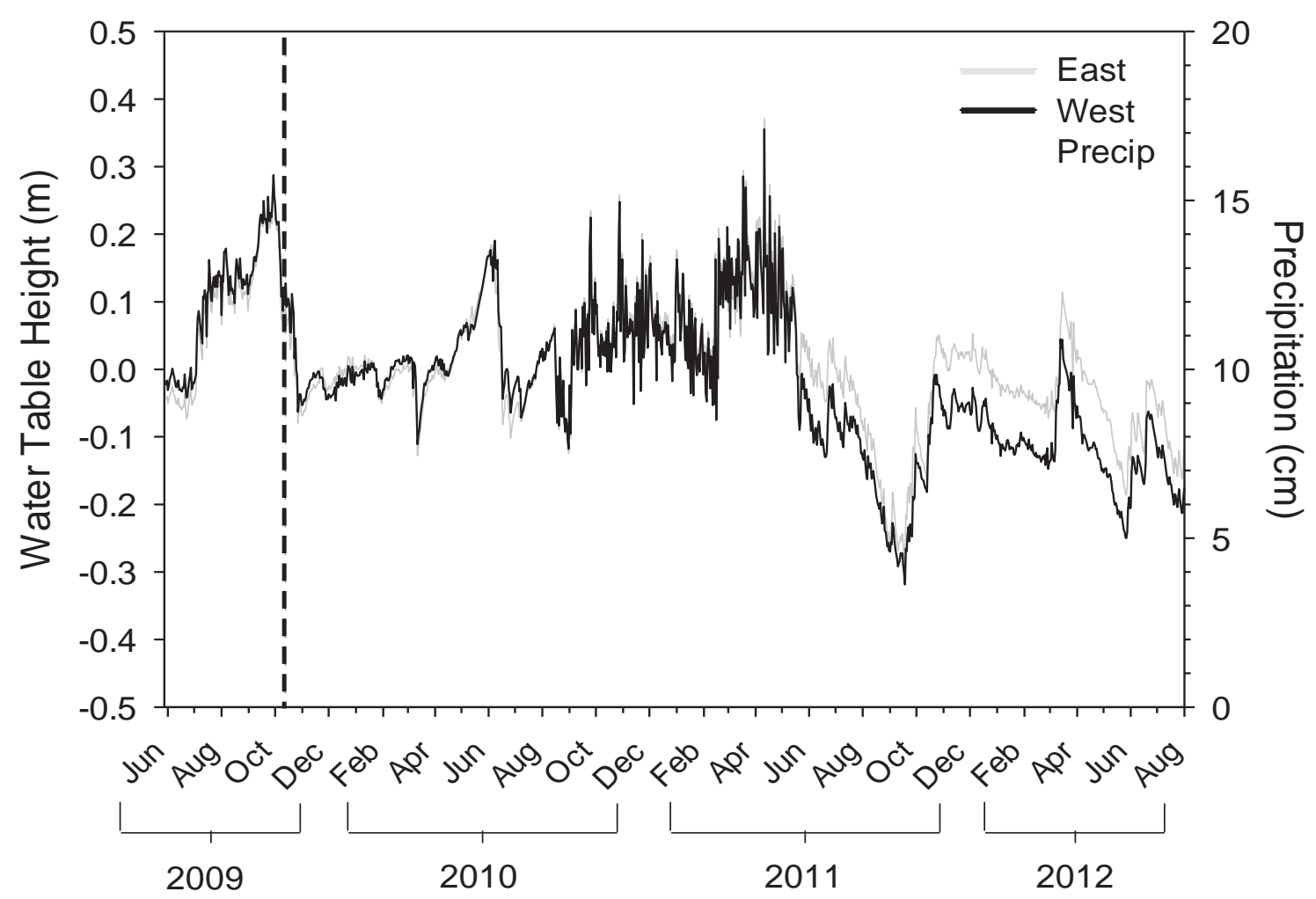

Figure 3.2. Water table height in sector 2 of the Sleeper Lake Fen restoration site with local (Newberry, MI) precipitation data before and after restoration (20092012). Dashed line shows when ditch filling was completed. 


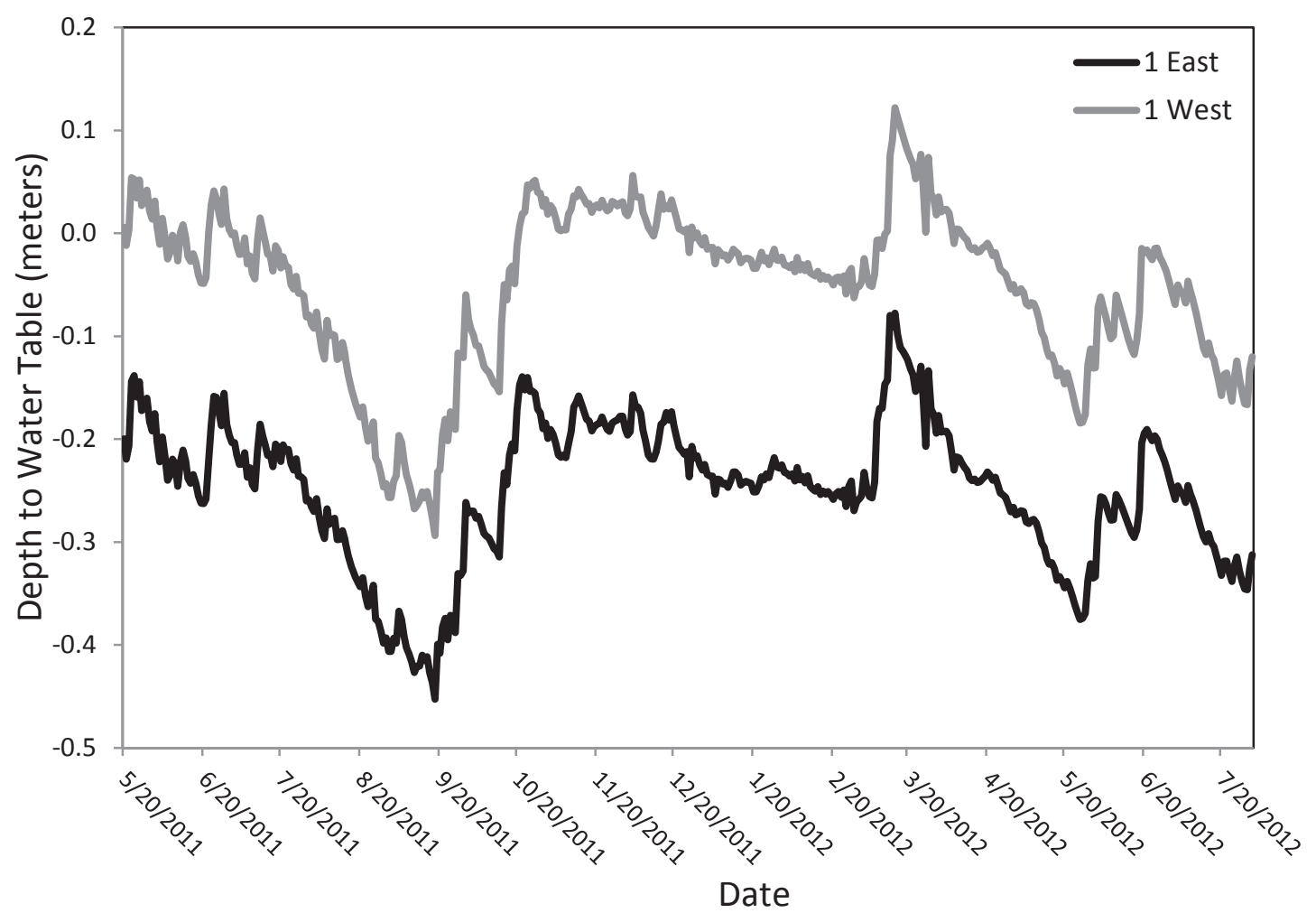

Figure 3.3. Water table heights in sector 1 following restoration at the Sleeper Lake Fen site (2011-2012). 


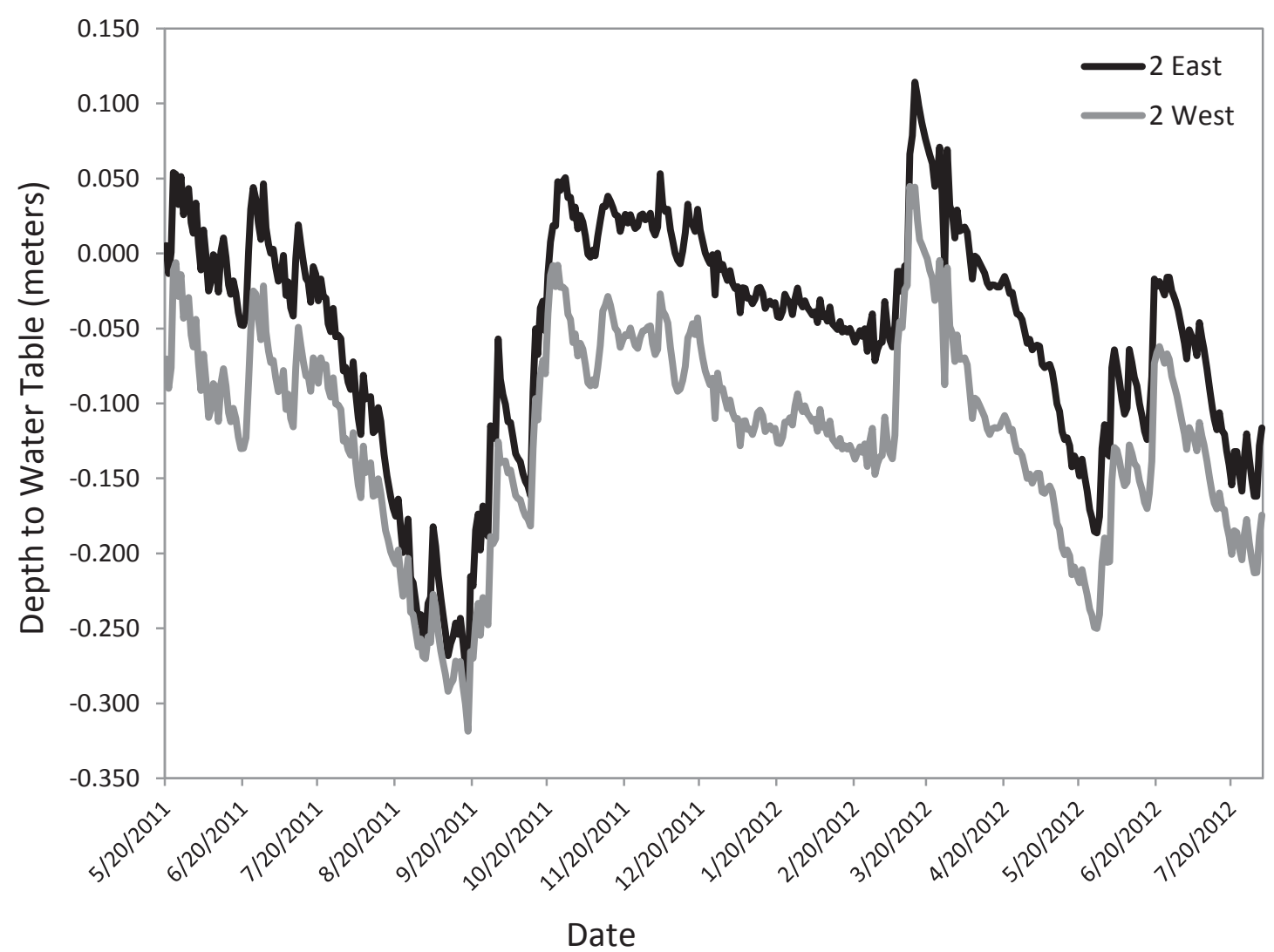

Figure 3.4. Water table heights in sector 2 following restoration at the Sleeper Lake Fen site (2011-2012). 


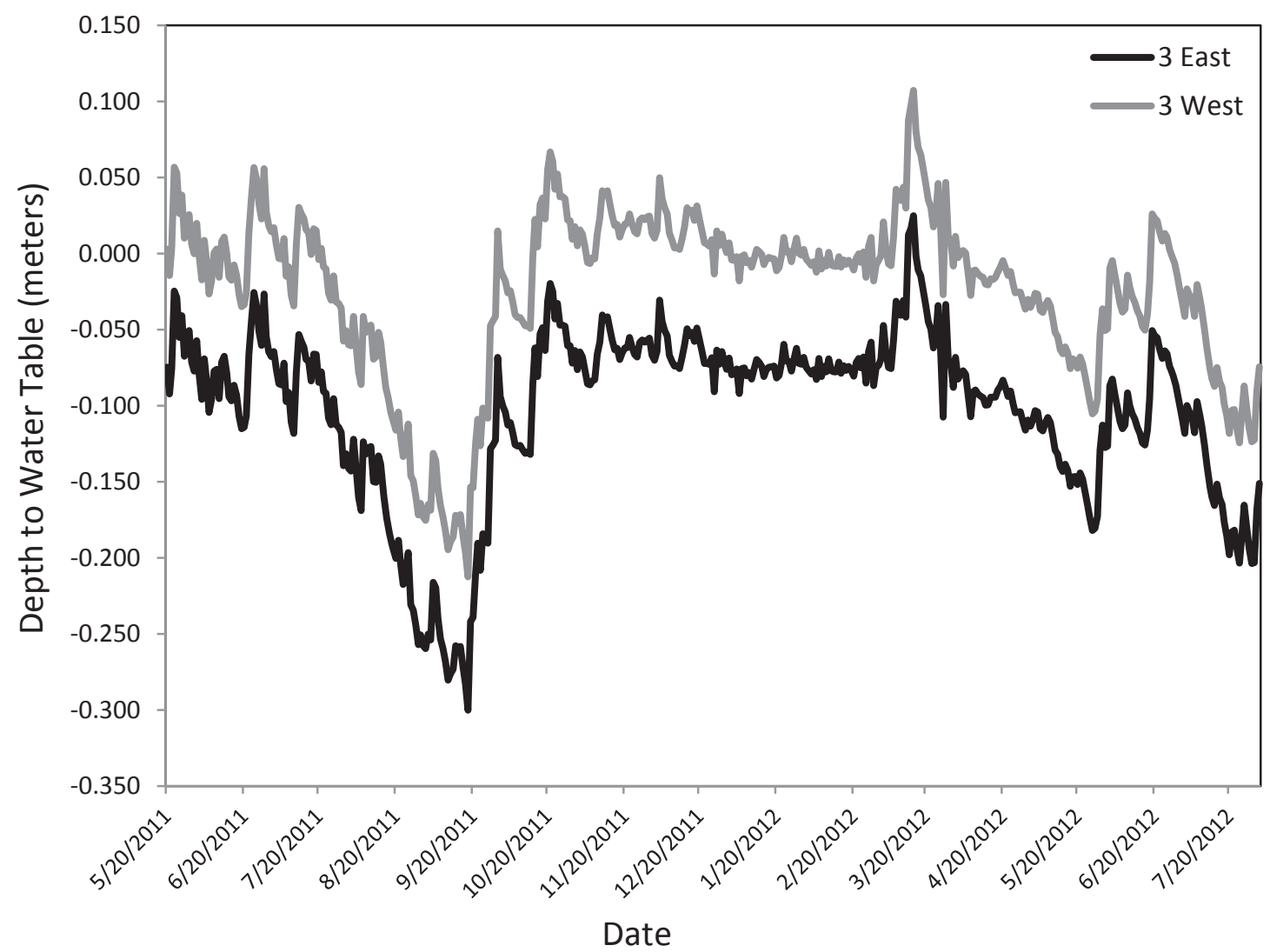

Figure 3.5. Water table heights in sector 3 following restoration at the Sleeper Lake Fen site (2011-2012). 


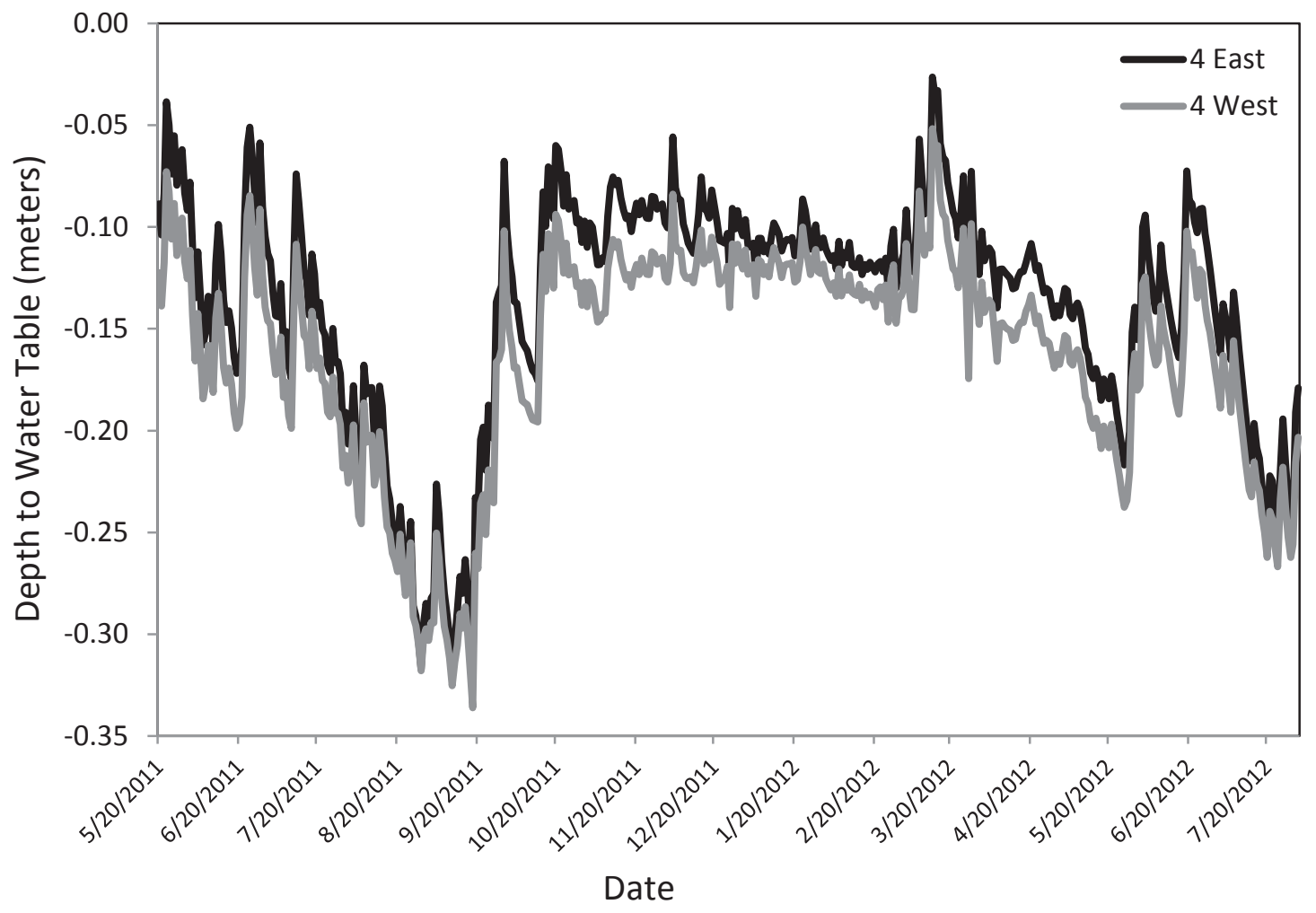

Figure 3.6. Water table heights in sector 4 following restoration at the Sleeper Lake Fen site (2011-2012). 


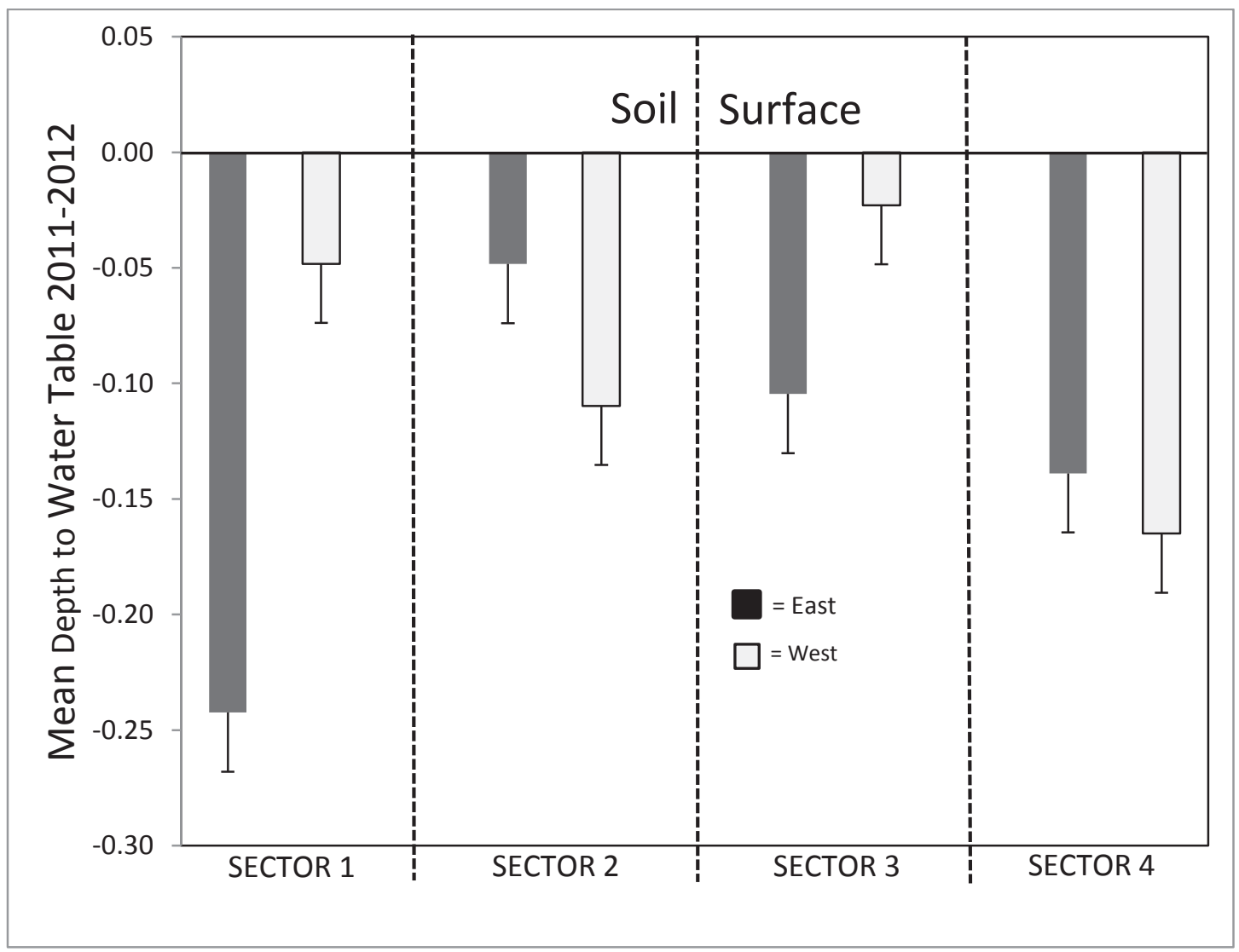

Figure 3.7. Mean depth to water table in the four sectors of the Sleeper Lake Fen restoration site from May, 2011 through August, 2012. Bars represent standard error. 


\section{0}
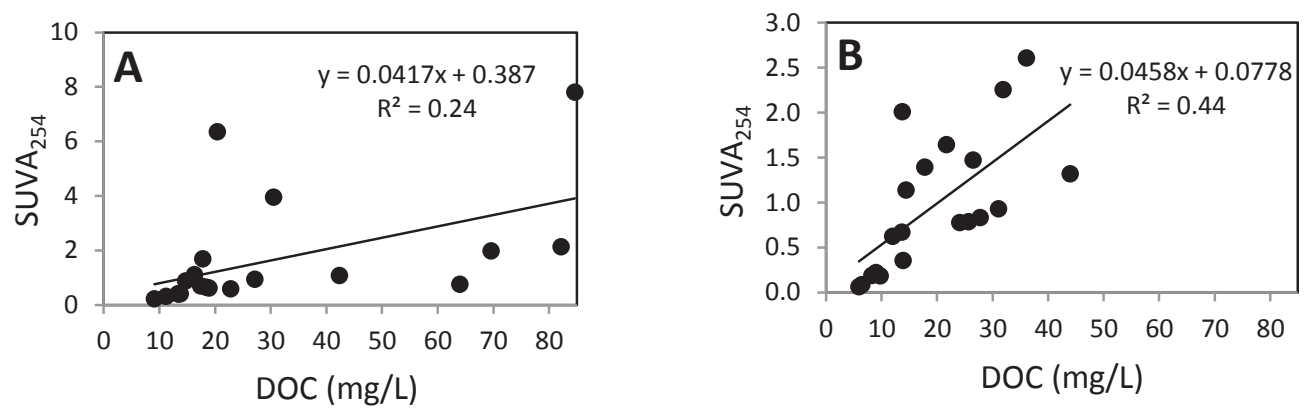

\section{1}
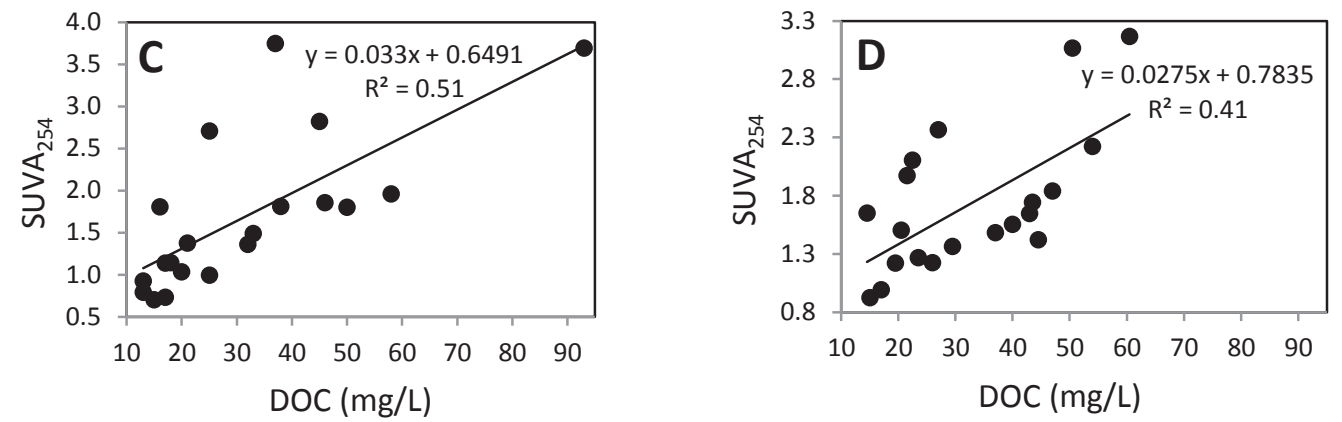

Figure 3.8. Regressions of $\mathrm{SUVA}_{254}$ Vs DOC concentrations at the Sleeper Lake Fen restoration site. A.) Restored ditch (November, 2010), B.) Undisturbed fen (November, 2010), C.) Restored ditch (May, 2011), D.) Undisturbed fen (May, 2011). SUVA $254=$ Specific Ultraviolet Absorbance at 254nm wavelength; DOC $=$ Dissolved Organic Carbon. 


\section{Ditch}
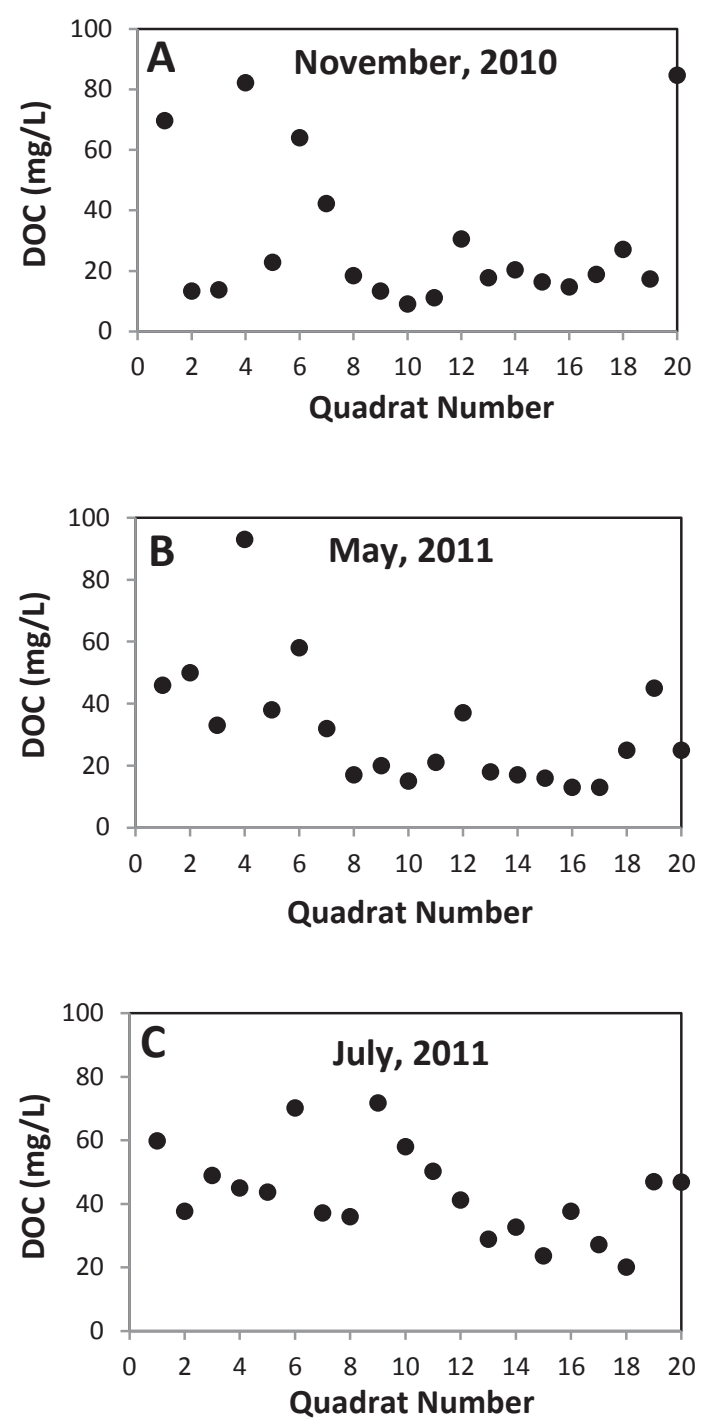

Undisturbed
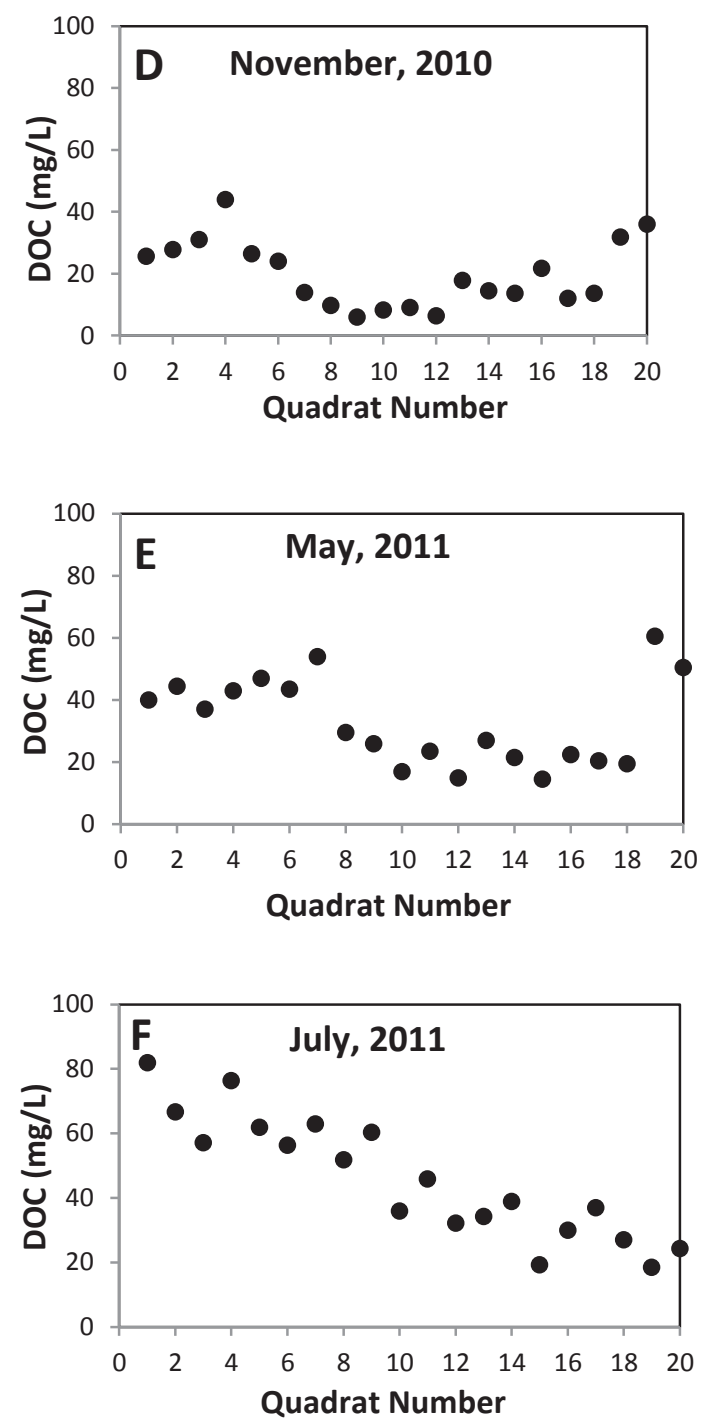

Figure 3.9. Correlation of DOC concentration vs quadrat number in the restored ditch and undisturbed fen at the Sleeper Lake Fen restoration site (November, 2010 to July, 2011 data). Quadrat 1-5 are in sector 1 at south end of ditch, quadrats 6-10 are in sector 2, quadrats $11-15$ are in sector 3 and quadrats 1620 are in sector 4 at north end of ditch. 

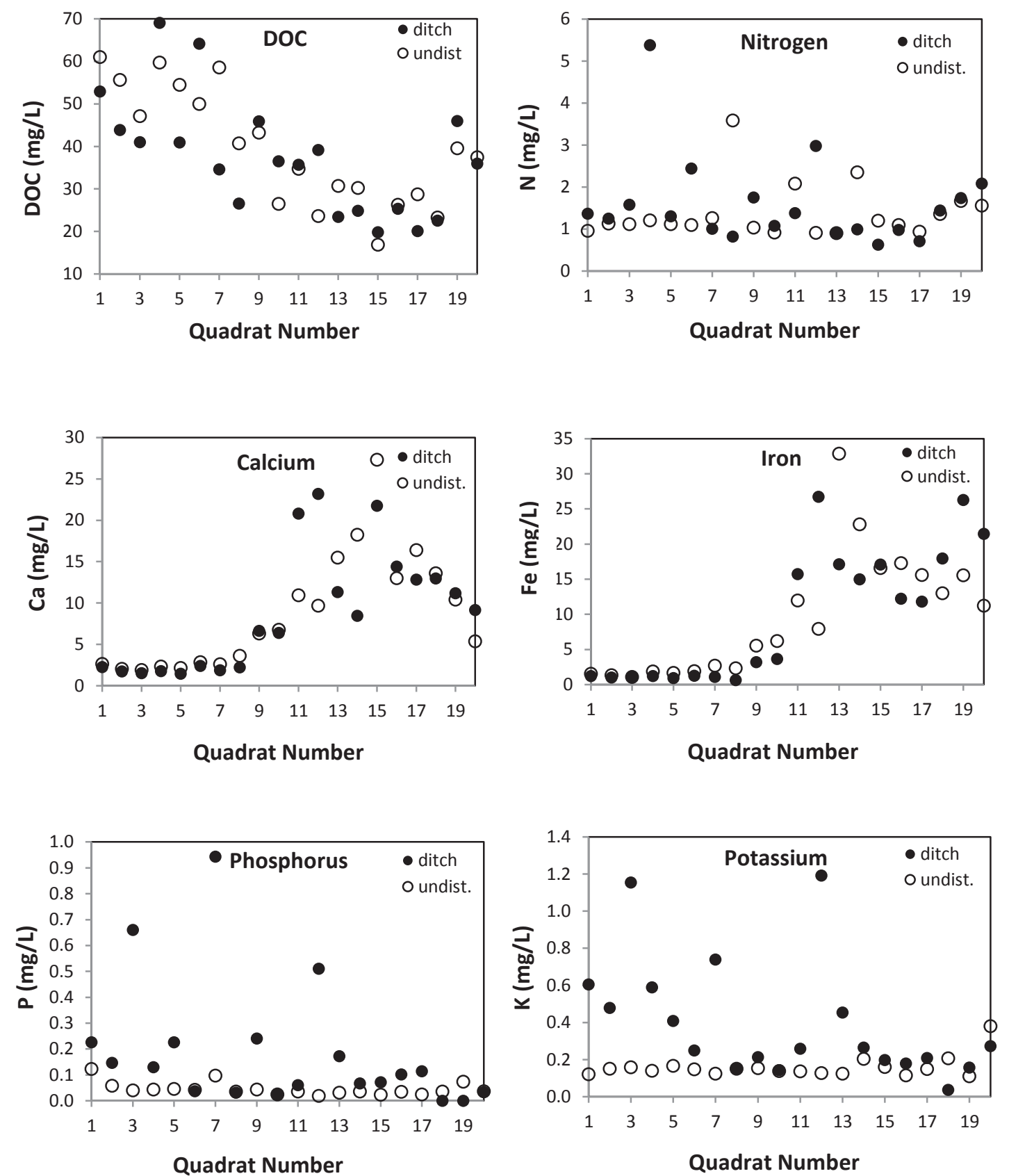

Figure 3.10 Comparisons of 2011 mean porewater chemical data between the ditch $(\bullet)$ and undisturbed ( $\circ$ ) fen quadrats at the Sleeper Lake Fen restoration site. 


\section{Restored Ditch}
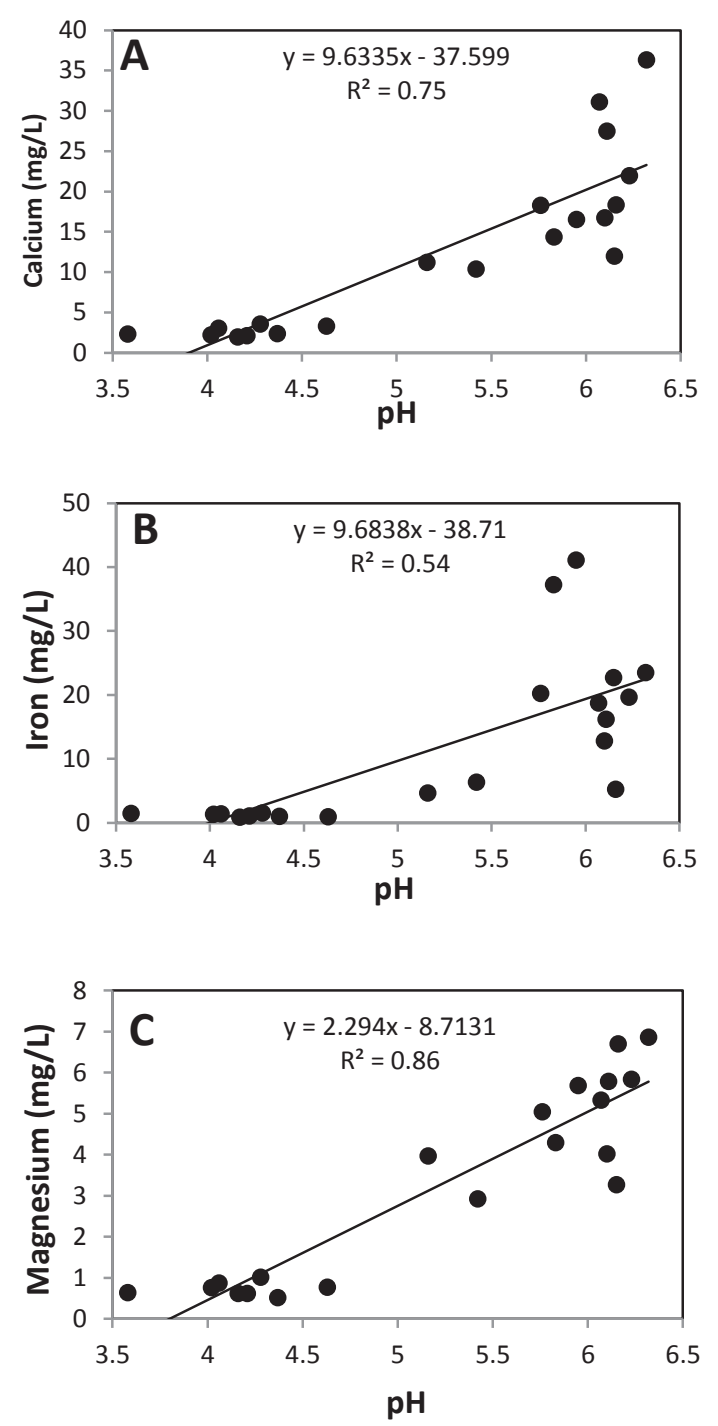

Undisturbed Fen
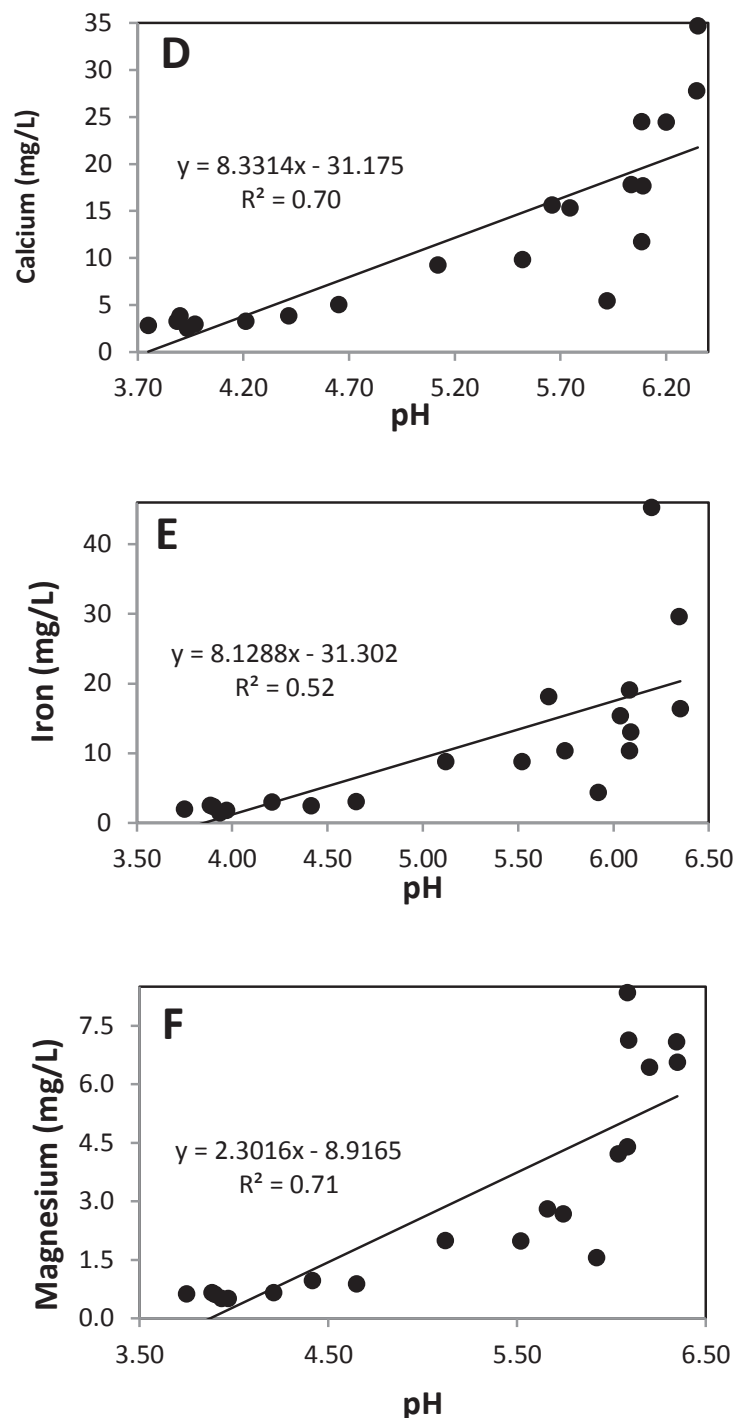

Figure 3.11A-G. Regressions of metals concentrations vs $\mathrm{pH}$ in the restored ditch and undisturbed fen at the Sleeper Lake Fen restoration site (July, 2011 data). $\mathrm{A}-\mathrm{C}=$ restored ditch, $\mathrm{D}-\mathrm{F}=$ undisturbed fen. 
Restored Ditch
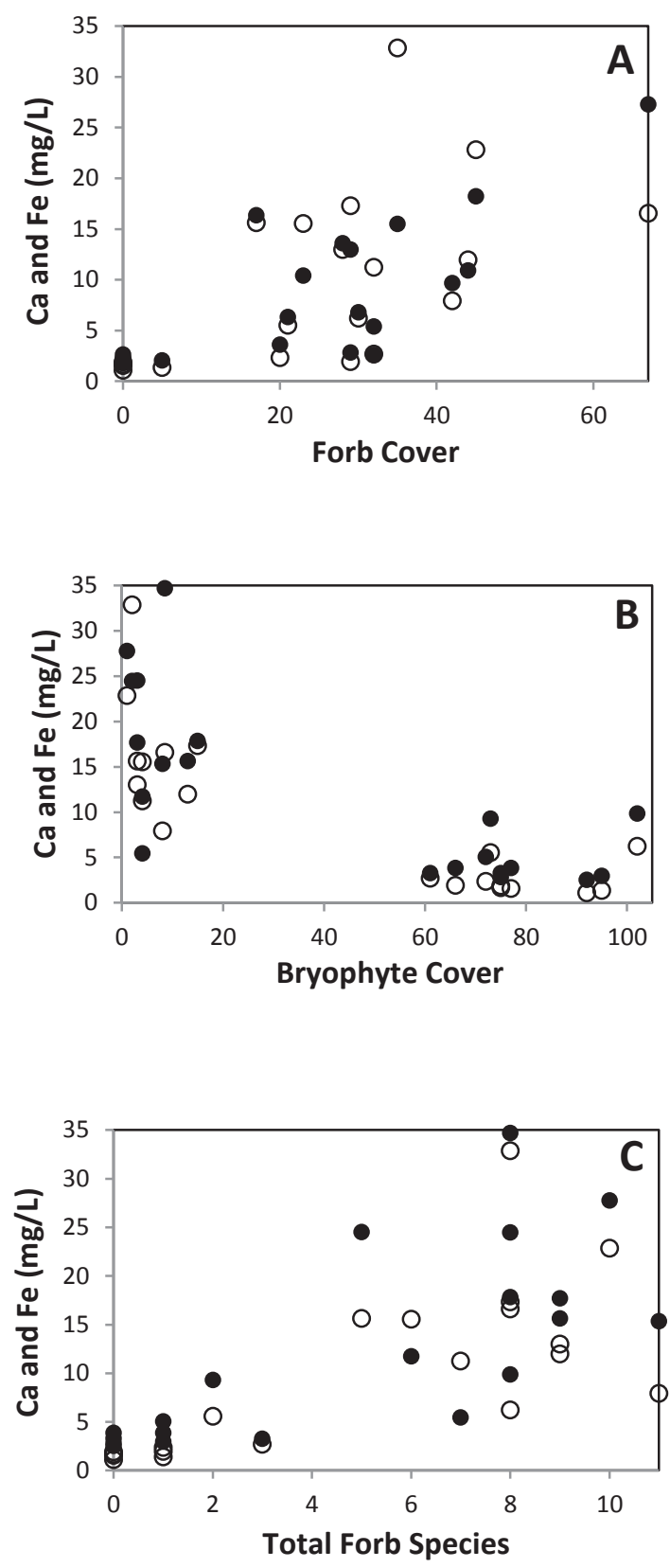

Undisturbed Fen
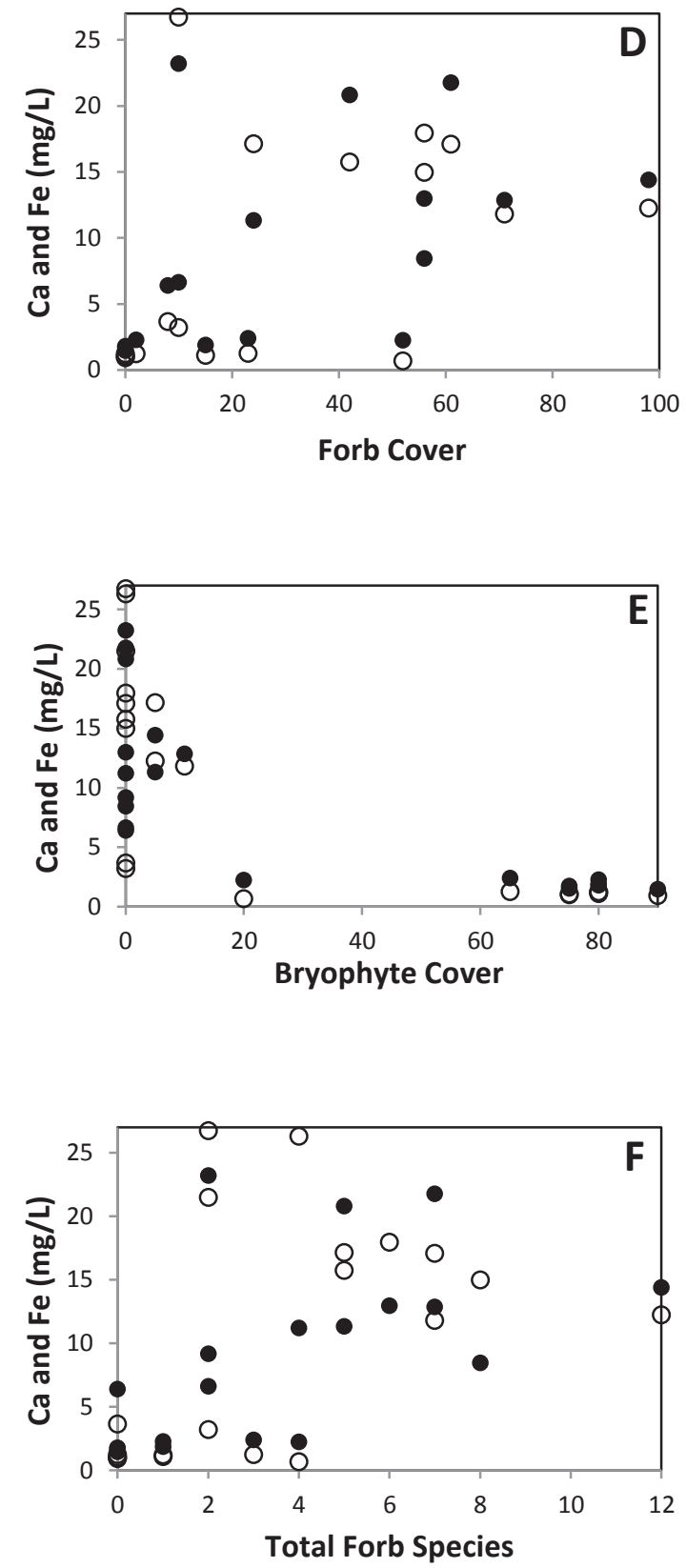

Figure 3.12A-F. Correlation of 2011 vegetative parameters vs mean $2011 \mathrm{Ca}, \mathrm{Fe}$ and $\mathrm{Mg}$ concentrations in the undisturbed fen and restored ditch at the Sleeper Lake Fen site. A-C) restored ditch, D-F) undisturbed fen. Solid circles $=\mathrm{Ca}$, open circles $=\mathrm{Fe}$. 
Restored Ditch
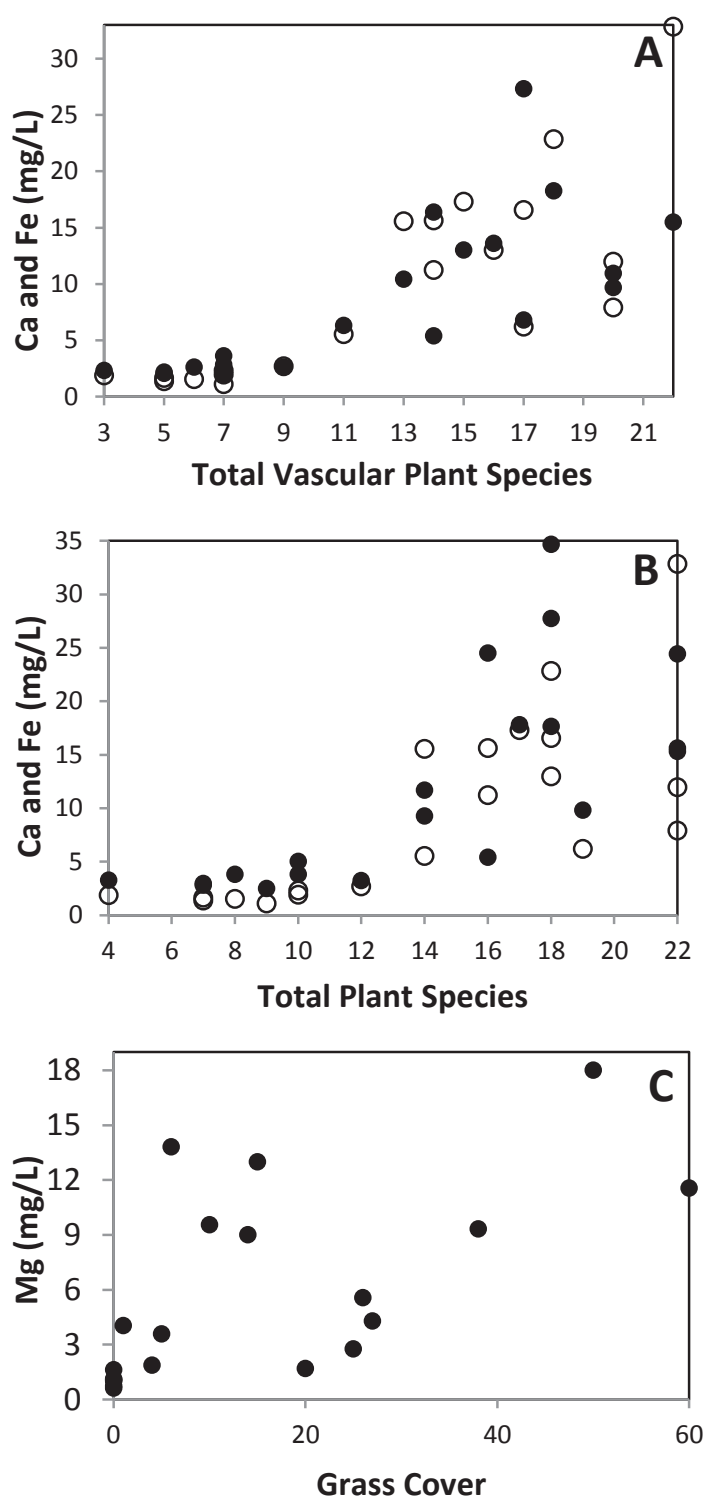

Undisturbed Fen
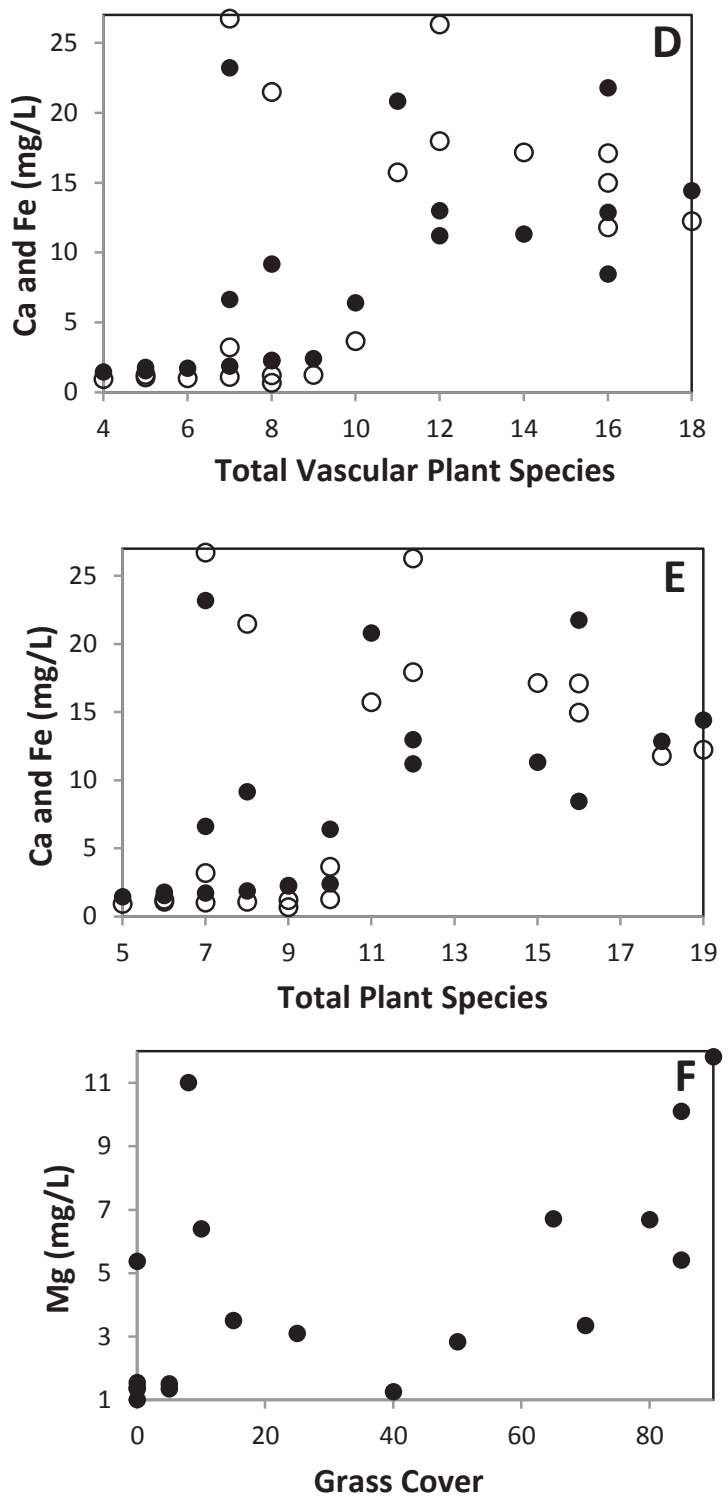

Figure 3.13. Correlation of 2011 vegetative parameters vs mean $2011 \mathrm{Ca}, \mathrm{Fe}$ and $\mathrm{Mg}$ concentrations in the undisturbed fen and restored ditch at the Sleeper Lake Fen restoration site. A-C) undisturbed fen, D-F) restored ditch. Solid circles $=\mathrm{Ca}$ or $\mathrm{Mg}$, open circles $=\mathrm{Fe}$. 


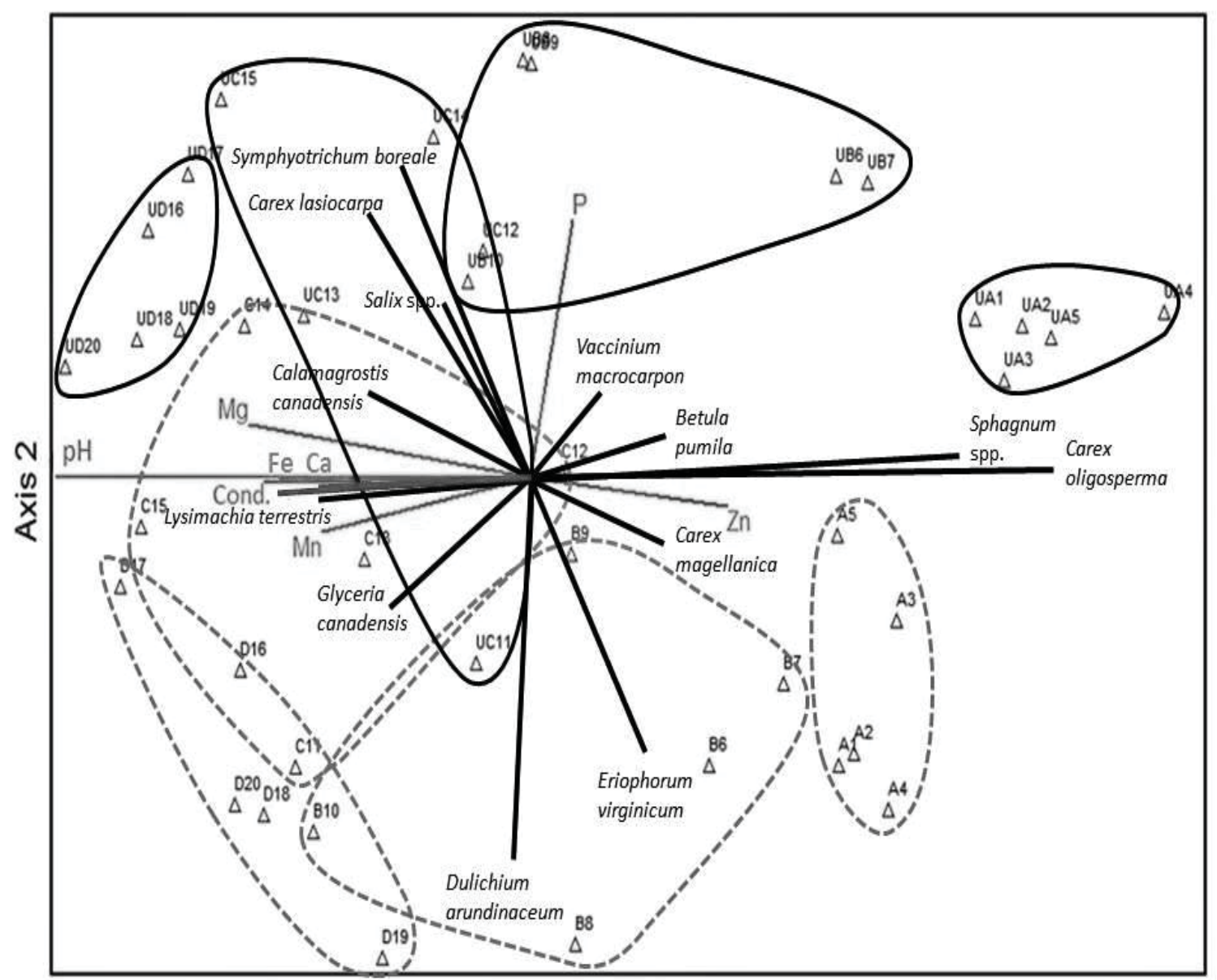

Axis 1

Figure 3.14. NMS ordination of restored and undisturbed vegetation with pore water parameters at the Sleeper Lake Fen restoration site. Groups with solid black boundaries are undisturbed plots (U). A-D = Sectors 1-4, respectively. Boundaries drawn around groupings are for illustrative purposes only as they have no statistical significance. 
Table 3.1. A) November, 2010 and B) May, 2011 Pore water chemistry among the four sectors in restored and undisturbed peatland at the Sleeper Lake Fen restoration site. Restored values are means across the 5 sampling plots in each sector; undisturbed values are averaged across the 10 sample plots ( 5 from each side) in each sector.

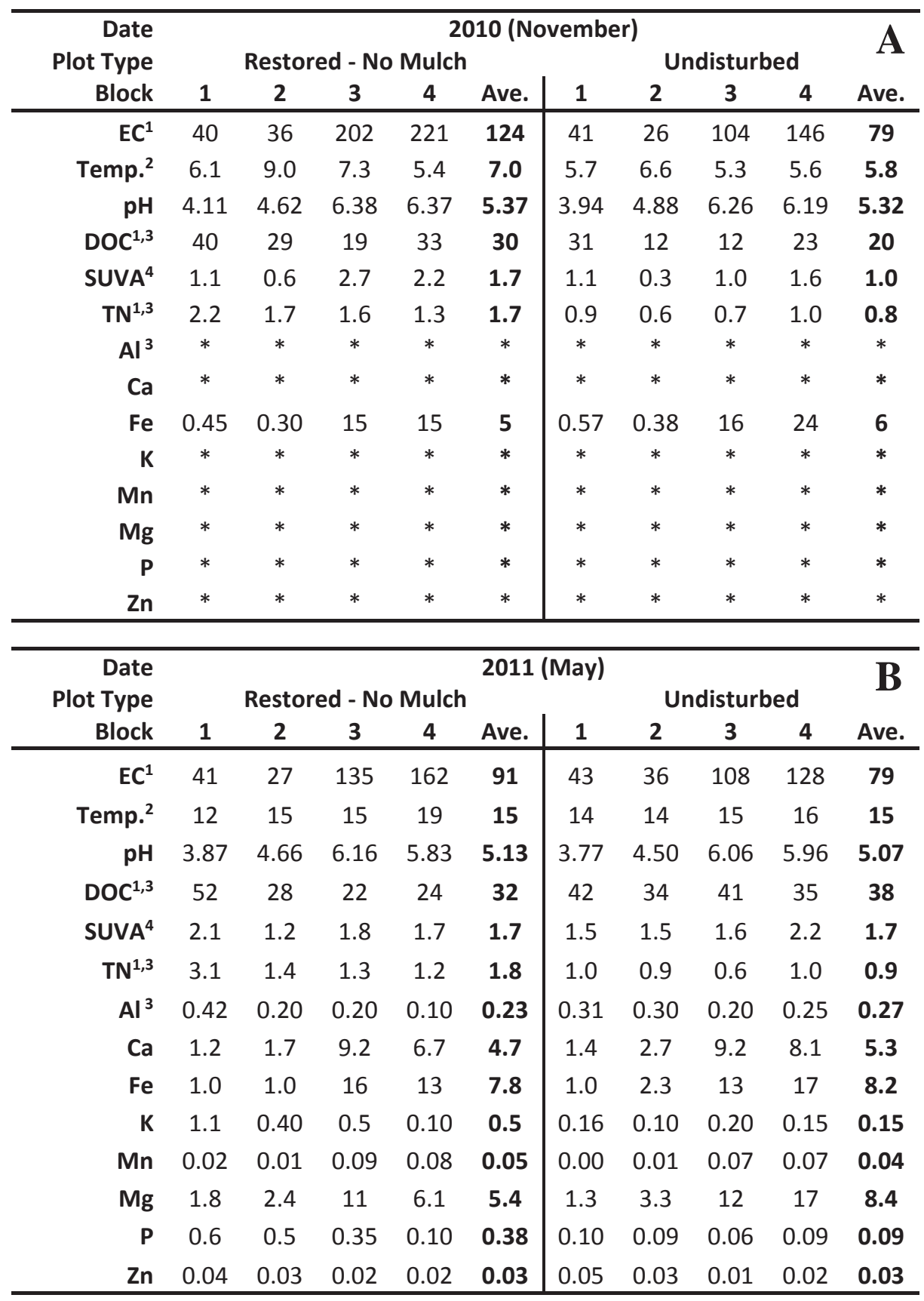

* = data not collected; 1 : EC = Electrical Conductivity, $\mathrm{DOC}=$ Dissolved Organic Carbon, $\mathrm{TN}=$ Total Nitrogen 2: Temp. is degrees Centigrade, 3: all elements are in $\mathrm{mg} / \mathrm{L}$; 4: SUVA is Specific UV Absorbance at $254 \mathrm{~nm} / \mathrm{cm}-1$ 
Table 3.1. C) July, 2011 Pore water chemistry among the four sectors in restored and undisturbed peatland at the Sleeper Lake Fen restoration site. Restored values are means across the 5 sampling plots in each sector; undisturbed values are averaged across the 10 sample plots ( 5 from each side) in each sector.

\begin{tabular}{rccccc|ccccc}
\hline $\begin{array}{r}\text { Date } \\
\text { Plot Type }\end{array}$ & \multicolumn{1}{c}{ Restored - No Mulch } \\
Sector & $\mathbf{1}$ & $\mathbf{2}$ & $\mathbf{3}$ & $\mathbf{4}$ & Ave. & $\mathbf{1}$ & $\mathbf{2}$ & $\mathbf{3}$ & $\mathbf{4}$ & Ave. \\
\hline EC $^{1}$ & 43 & 43 & 239 & 227 & $\mathbf{1 3 8}$ & 52 & 50 & 214 & 167 & $\mathbf{1 2 1}$ \\
Temp. $^{2}$ & 26 & 23 & 23 & 21 & $\mathbf{2 3}$ & 23 & 22 & 21 & 20 & $\mathbf{2 2}$ \\
pH $^{2}$ & 4 & 5 & 6 & 6 & $\mathbf{5}$ & 4 & 5 & 6 & 6 & $\mathbf{5}$ \\
DOC $^{1,3}$ & 47 & 55 & 35 & 36 & $\mathbf{4 3}$ & 63 & 54 & 34 & 27 & $\mathbf{4 5}$ \\
SUVA $^{4}$ & $*$ & $*$ & $*$ & $*$ & $*$ & $*$ & $*$ & $*$ & $*$ & $*$ \\
TN $^{1,3}$ & 1 & 1 & 1 & 2 & $\mathbf{1}$ & 1 & 1 & 1 & 1 & $\mathbf{1}$ \\
$\mathbf{A l}^{\mathbf{3}}$ & 0.39 & 0.40 & 0.38 & 0.25 & $\mathbf{0 . 3 6}$ & 0.46 & 0.45 & 0.26 & 0.19 & $\mathbf{0 . 3 4}$ \\
$\mathbf{C a}$ & 2 & 6 & 25 & 18 & $\mathbf{1 3}$ & 3 & 6 & 24 & 15 & $\mathbf{1 2}$ \\
$\mathbf{F e}$ & 1 & 3 & 20 & 23 & $\mathbf{1 2}$ & 2 & 5 & 24 & 12 & $\mathbf{1 1}$ \\
$\mathbf{K}$ & 0.18 & 0.18 & 0.45 & 0.20 & $\mathbf{0 . 2 5}$ & 0.14 & 0.14 & 0.13 & 0.20 & $\mathbf{0 . 1 5}$ \\
$\mathbf{M n}$ & 0.05 & 0.04 & 0.26 & 0.22 & $\mathbf{0 . 0 8}$ & 0.01 & 0.03 & 0.21 & 0.13 & $\mathbf{0 . 1 0}$ \\
$\mathbf{M g}$ & 1 & 2 & 5 & 5 & $\mathbf{3}$ & 1 & 1 & 5 & 5 & $\mathbf{3}$ \\
$\mathbf{P}$ & 0.00 & 0.00 & 0.00 & 0.00 & $\mathbf{0 . 0 0}$ & 0.02 & 0.02 & 0.00 & 0.00 & $\mathbf{0 . 0 1}$ \\
$\mathbf{Z n}$ & 0.04 & 0.03 & 0.02 & 0.02 & $\mathbf{0 . 3 5}$ & 0.04 & 0.04 & 0.02 & 0.02 & $\mathbf{0 . 0 3}$ \\
\hline
\end{tabular}

* = data not collected; 1 : EC = Electrical Conductivity, DOC = Dissolved Organic Carbon, TN = Total Nitrogen 2: Temp. is degrees Centigrade, 3: DOC, TN and all elements are in $\mathrm{mg} / \mathrm{L}$; 4 : SUVA is Specific UV Absorbance at $254 \mathrm{~nm} / \mathrm{cm}^{-1}$. 
Table 3.2. ANOVA results for pore water parameters in undisturbed fen and restored ditch at the Sleeper Lake Fen restoration site (2010-2011 data).

\begin{tabular}{|c|c|c|c|c|c|c|c|c|}
\hline \multirow[b]{2}{*}{$\begin{array}{l}\text { Porewater } \\
\text { Parameter }\end{array}$} & \multicolumn{7}{|c|}{ Undisturbed Fen vs Restored Ditch } & \multirow[b]{2}{*}{$R^{2}$} \\
\hline & Root MSE & y1 Mean ${ }^{1}$ & $\begin{array}{l}\text { y1 F- } \\
\text { stat }\end{array}$ & y1 P-value & $\begin{array}{l}\text { Sector Effect } \\
\text { P-val }\end{array}$ & $\begin{array}{c}\text { Treat Effect } \\
\text { P-val }\end{array}$ & $\begin{array}{l}\text { Sector*Treat } \\
\text { p-val }\end{array}$ & \\
\hline Aluminum & 0.09 & 0.30 & 5.11 & $0.0006^{*}$ & $<.0001^{*}$ & 0.92 & 0.39 & 0.53 \\
\hline Calcium & 3.97 & 8.72 & 13 & $<.0001^{*}$ & $<.0001^{*}$ & 0.98 & 0.98 & 0.74 \\
\hline Iron & 4.68 & 9.20 & 18 & $<.0001^{*}$ & $<.0001 *$ & $.008^{*}$ & $.018^{*}$ & 0.80 \\
\hline Magnesium & 2.73 & 5.03 & 10 & $<.0001^{*}$ & $<.0001 *$ & 0.12 & 0.07 & 0.69 \\
\hline Manganese & 0.04 & 0.08 & 20 & $<.0001^{*}$ & $<.0001 *$ & $.015^{*}$ & 0.58 & 0.81 \\
\hline Phosphorus & 0.18 & 0.12 & 1.75 & 0.133 & 0.39 & $.014^{*}$ & 0.53 & 0.28 \\
\hline Potassium & 0.21 & 0.28 & 4.14 & $0.002 *$ & 0.11 & $.0009 *$ & $.047^{*}$ & 0.48 \\
\hline Zinc & 0.01 & 0.03 & 5.53 & $0.0003^{*}$ & $.0001^{*}$ & $.031^{*}$ & 0.20 & 0.55 \\
\hline Total DOC & 11 & 34 & 3.33 & $0.009 *$ & $.0006^{*}$ & 0.54 & 0.96 & 0.42 \\
\hline Total Nitrogen & 1.10 & 1.49 & 0.51 & 0.82 & 0.96 & 0.44 & 0.47 & 0.10 \\
\hline C:N Ratio & 7.84 & 26 & 4.01 & $0.003 *$ & $.001 *$ & 0.53 & 0.10 & 0.47 \\
\hline C:P Ratio & 608 & 755 & 2.40 & $0.043^{*}$ & 0.09 & 0.69 & $0.04 *$ & 0.34 \\
\hline Fe: PO4 Ratio & 4731 & 8932 & 19 & $<.0001^{*}$ & $<.0001^{*}$ & $.008^{*}$ & $0.02 *$ & 0.81 \\
\hline K:P Ratio & 2.80 & 4.18 & 1.12 & 0.37 & 0.13 & 0.72 & 0.64 & 0.20 \\
\hline N:P Ratio & 31 & 35 & 2.36 & $0.046^{*}$ & 0.08 & 0.06 & $.048^{*}$ & 0.34 \\
\hline SUVA & 0.89 & 1.50 & 1.56 & 0.18 & 0.08 & 0.23 & 0.59 & 0.26 \\
\hline
\end{tabular}

*: Significant at the alpha $=0.05$

1: Mean values are averages of May vs July, 2011 porewater samples, except for DOC, total $\mathrm{N}$ and Fe, which include November, 2010 porewater values as well.

Treat $=$ Treatment (undisturbed fen or restored ditch) 
Table 3.3. Organic acid and anion concentrations ( $\mathrm{ppm}$ ) measured in pore water samples from the A) restored ditch and B) undisturbed fen at the Sleeper Lake Fen restoration site (2010-2011).

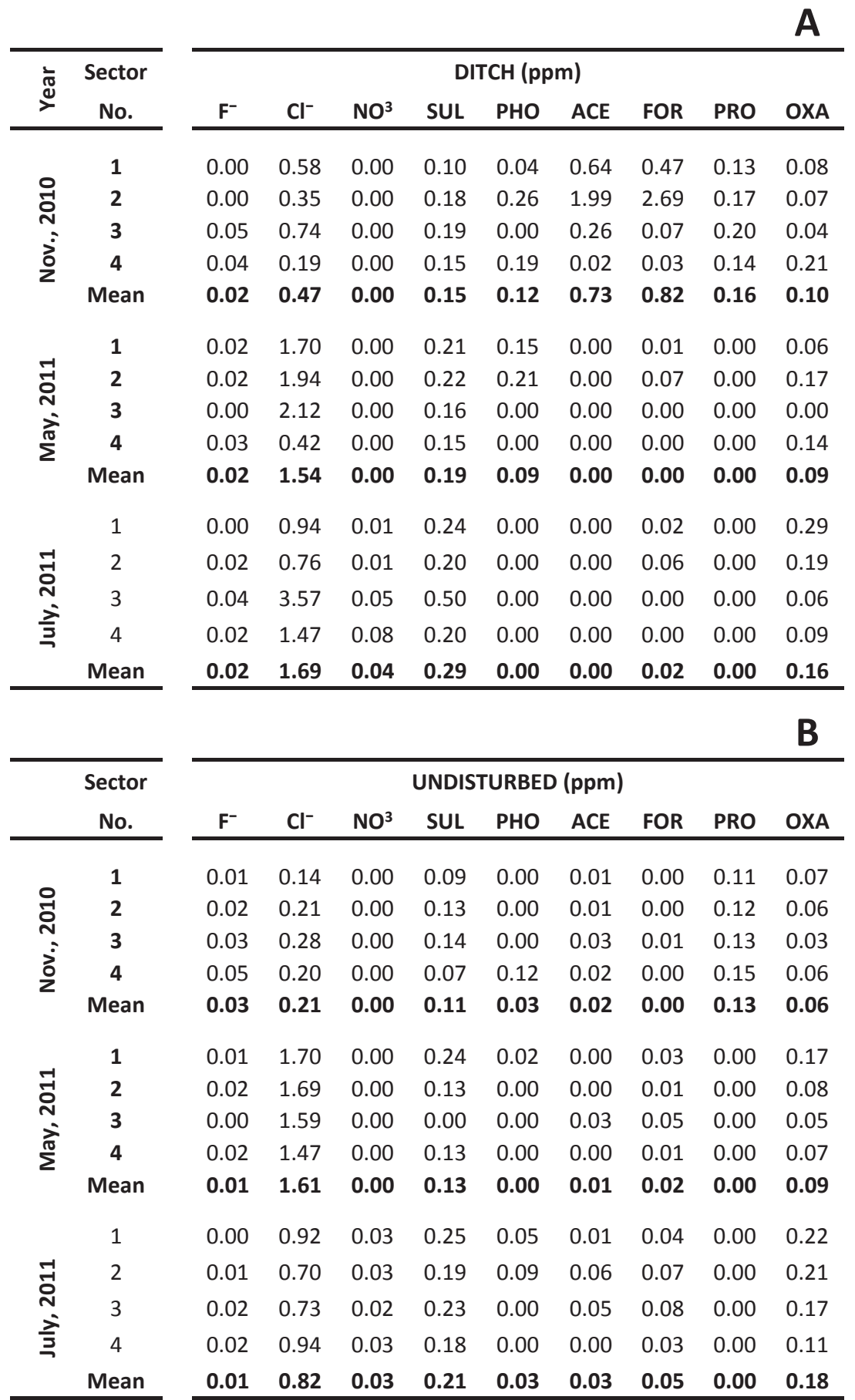

1: $\mathrm{F}=$ fluoride, $\mathrm{Cl}=$ chloride, $\mathrm{NO} 3$ = nitrate, $\mathrm{SUL}=$ sulfate, $\mathrm{PHO}=$ phosphate, $\mathrm{ACE}=$ acetate, $\mathrm{FOR}=$ formate, $\mathrm{PRO}=$ propionate, $\mathrm{OXA}=$ oxalate 
Table 3.4. Pore water characteristics and maximum cover values for calciphilic plant species in the undisturbed and restored fen at the Sleeper Lake Fen restoration site - A.) 2010 undisturbed fen data, B.) 2011 restored ditch data.

A

\begin{tabular}{rcccccccccc}
\hline \multicolumn{1}{c}{ Scientific Name } & $\begin{array}{c}\text { Max } \\
\text { Cover }\end{array}$ & Sector & $\begin{array}{c}\text { Plot } \\
\text { \# }\end{array}$ & $\mathbf{p H}$ & $\mathbf{E C}^{\mathbf{1}}$ & $\mathbf{F e}^{2}$ & $\mathbf{C a}^{2}$ & $\mathbf{M g}^{\mathbf{2}}$ & DOC $^{\mathbf{1 , 2}}$ & TN $^{\mathbf{1 , 2}}$ \\
\hline Campanula aparinoides & 20 & 4 & $20 \mathrm{E}$ & 5.89 & 71 & 3 & 4 & 0.8 & 22 & 0.9 \\
Doellingeria umbellata & 10 & 4 & $20 \mathrm{E}$ & 5.89 & 71 & 3 & 4 & 0.8 & 22 & 0.9 \\
Galium brevipes & 25 & 3 & $15 \mathrm{~W}$ & 6.37 & 307 & 20 & 36 & 7.0 & 28 & 0.9 \\
Potentilla palustris & 18 & 3 & $12 \mathrm{~W}$ & 5.83 & 100 & 11 & 14 & 2.3 & 30 & 1.0 \\
Scutellaria galericulata & 6 & 4 & $20 \mathrm{E}$ & 5.89 & 71 & 3 & 4 & 0.8 & 22 & 0.9 \\
Smilacina trifolia & 6 & 4 & $18 \mathrm{E}$ & 6.01 & 182 & 12 & 18 & 5.9 & 21 & 0.6 \\
Solidago uliginosa & 30 & 3 & $15 \mathrm{~W}$ & 6.37 & 307 & 20 & 36 & 7.0 & 28 & 0.9 \\
Symphyotrichum boreale & 12 & 3 & $14 \mathrm{~W}$ & 6.30 & 241 & 26 & 28 & 6.0 & 36 & 1.0 \\
Viola macloskeyi & 6 & 4 & $20 \mathrm{E}$ & 5.89 & 71 & 3 & 4 & 0.8 & 22 & 0.9 \\
\hline
\end{tabular}

B

\begin{tabular}{|c|c|c|c|c|c|c|c|c|c|c|}
\hline Scientific Name & $\begin{array}{l}\text { Max } \\
\text { Cover }\end{array}$ & Sector & $\begin{array}{c}\text { Plot } \\
\#\end{array}$ & $\mathrm{pH}$ & $\mathrm{EC}^{1}$ & $\mathrm{Fe}^{2}$ & $\mathrm{Ca}^{2}$ & $\mathbf{M g}^{2}$ & DOC $^{1,2}$ & $\mathrm{TN}^{1,2}$ \\
\hline Campanula aparinoides & 15 & 4 & $17 C$ & 6.10 & 167 & 13 & 17 & 4 & 27 & 0.9 \\
\hline Cicuta bulbifera & 8 & 4 & $17 \mathrm{~B}$ & 6.10 & 167 & 13 & 17 & 4 & 27 & 0.9 \\
\hline Doellingeria umbellata & 12 & 4 & $16 B$ & 6.23 & 184 & 20 & 22 & 6 & 38 & 1.3 \\
\hline Epilobium leptophyllum & 5 & 4 & $16 B$ & 6.23 & 184 & 20 & 22 & 6 & 38 & 1.3 \\
\hline Galium brevipes & 40 & 4 & $16 \mathrm{~A}$ & 6.23 & 184 & 20 & 22 & 6 & 38 & 1.3 \\
\hline Potentilla palustris & 15 & 2 & $10 \mathrm{C}$ & 5.42 & 57 & 1 & 2 & 3 & 58 & 1.6 \\
\hline Rumex orbiculatus & 12 & 4 & 17B & 6.10 & 167 & 13 & 17 & 4 & 27 & 0.9 \\
\hline Scutellaria galericulata & 10 & 4 & 17B & 6.10 & 167 & 13 & 17 & 4 & 27 & 0.9 \\
\hline Smilacina trifolia & 5 & 3 & $14 B$ & 6.15 & 239 & 7 & 5 & 7 & 33 & 1.3 \\
\hline Solidago uliginosa & 8 & 4 & $17 \mathrm{~B}$ & 6.10 & 167 & 13 & 17 & 4 & 27 & 0.9 \\
\hline Symphyotrichum boreale & 10 & 3 & $14 C$ & 6.15 & 239 & 7 & 5 & 7 & 33 & 1.3 \\
\hline Viola macloskeyi & 15 & 4 & $17 \mathrm{C}$ & 6.10 & 167 & 13 & 17 & 4 & 27 & 0.9 \\
\hline
\end{tabular}

1: $\mathrm{EC}=$ Electrical Conductivity, $\mathrm{DOC}=$ Dissolved Organic Carbon, $\mathrm{TN}=$ total Nitrogen.

2: values are in $\mathrm{mg} / \mathrm{L}$. 
Table 3.5. Pore water characteristics and maximum cover values for acidophilic plant species in the undisturbed and restored fen at the Sleeper Lake Fen restoration - A.) 2010 undisturbed fen data, B.) 2011 restored ditch data.

\begin{tabular}{|c|c|c|c|c|c|c|c|c|c|c|}
\hline Scientific Name & $\begin{array}{l}\text { Max } \\
\text { Cover }\end{array}$ & Sector & $\begin{array}{c}\text { Plot } \\
\#\end{array}$ & $\mathrm{pH}$ & $\mathrm{EC}^{1}$ & $\mathrm{Fe}^{2}$ & $\mathrm{Ca}^{2}$ & $\mathrm{Mg}^{2}$ & DOC $^{1,2}$ & TDN $^{1,2}$ \\
\hline Betula pumila & 35 & 1 & $1 \mathrm{E}$ & 3.89 & 55 & 2 & 3 & 0.6 & 96 & 1.8 \\
\hline Carex magellanica & 30 & 2 & $8 W$ & 4.47 & 32 & 4 & 6 & 1.0 & 53 & 1.3 \\
\hline Carex oligosperma & 80 & 1 & $5 \mathrm{E}$ & 3.71 & 50 & 2 & 2 & 0.5 & 54 & 1.3 \\
\hline Chamaedaphne calyculata & 40 & 1 & $5 W$ & 3.79 & 40 & 2 & 3 & 0.8 & 70 & 1.5 \\
\hline Eriophorum virginicum & 0 & - & - & - & - & - & - & - & - & - \\
\hline Feather Moss (Hypnaceae) & 50 & 2 & $6 \mathrm{~W}$ & 4.15 & 39 & 3 & 6 & 1.5 & 67 & 1.3 \\
\hline Polytrichum spp. & 40 & 1 & $5 \mathrm{E}$ & 3.71 & 50 & 2 & 2 & 0.5 & 54 & 1.3 \\
\hline Sphagnum spp. & 100 & 1 & $3 W$ & 3.92 & 44 & 2 & 3 & 0.8 & 66 & 1.5 \\
\hline Vaccinium macrocarpon & 60 & 2 & $8 W$ & 4.47 & 32 & 4 & 6 & 1.0 & 53 & 1.3 \\
\hline Scientific Name & $\begin{array}{l}\text { Max } \\
\text { Cover }\end{array}$ & Sector & $\begin{array}{c}\text { Plot } \\
\#\end{array}$ & $\mathrm{pH}$ & $\mathrm{EC}^{1}$ & $\mathrm{Fe}^{2}$ & $\mathrm{Ca}^{2}$ & $\mathrm{Mg}^{2}$ & $\mathrm{DOC}^{1,2}$ & TDN $^{1,2}$ \\
\hline Betula pumila & 5 & 1 & $1 \mathrm{~A}$ & 4.06 & 62 & 1 & 3 & 0.9 & 60 & 1.4 \\
\hline Carex magellanica & 80 & 2 & $6 C$ & 4.28 & 37 & 2 & 4 & 1.0 & 70 & 1.4 \\
\hline Carex oligosperma & 80 & 1 & $4 B$ & 4.02 & 51 & 1 & 2 & 0.8 & 45 & 1.6 \\
\hline Chamaedaphne calyculata & 40 & 1 & $4 C$ & 4.02 & 51 & 1 & 2 & 0.8 & 45 & 1.6 \\
\hline Eriophorum virginicum & 70 & 1 & $2 \mathrm{C}$ & 4.16 & 32 & 1 & 2 & 0.6 & 38 & 1.0 \\
\hline Feather Moss (Hypnaceae) & 10 & 4 & $16 C$ & 6.23 & 184 & 20 & 22 & 5.8 & 38 & 1.3 \\
\hline Polytrichum spp. & 5 & 4 & $17 \mathrm{~B}$ & 6.10 & 167 & 13 & 17 & 4.0 & 27 & 0.9 \\
\hline Sphagnum spp. & 90 & 1 & $5 B$ & 4.21 & 32 & 1 & 2 & 0.6 & 44 & 1.1 \\
\hline Vaccinium macrocarpon & 20 & 3 & $11 C$ & 6.32 & 218 & 23 & 36 & 6.9 & 50 & 1.6 \\
\hline
\end{tabular}

1: $\mathrm{EC}=$ Electrical Conductivity, $\mathrm{DOC}=$ Dissolved Organic Carbon, $\mathrm{TN}=$ total Nitrogen.

2: values are in $\mathrm{mg} / \mathrm{L}$. 


\section{Chapter 4.0 A Novel Approach to Establishing Coastal Wetlands on the Southern Shore of Lake Superior ${ }^{3}$}

\subsection{Abstract}

In 2009 , a project was begun to establish coastal wetland vegetation on the south shore of Lake Superior in the Keweenaw Peninsula of western Upper Michigan. Two, 33 $\mathrm{m}$ by $4 \mathrm{~m}$ sectors of coastline were selected that represented common coastal features in the region; one site was a filled, weedy yard edge and the other was covered with stamp sands left over from copper mining activities in the early and mid-twentieth century. Whereas other published freshwater coastal wetland restoration projects have used nursery stock to quickly establish vegetative cover, we wanted to test if seeds could be used as an economical alternative or supplement. Natural fiber geotextiles were used to hold the soil and seeds in place while the plants germinated and became established. Locally collected seeds from 47 wetland plant species were weighed into individual seed mixes for each site and cold stratified for 3 months. The $33 \mathrm{~m}$ long sectors of coastline were divided into 3 zones; emergent, wet meadow and shrub; planted with seeds appropriate for each zone and covered with geotextiles. Alternate plots were treated with $5 \mathrm{~cm}$ of milled peat moss prior to hand-broadcasting seeds, to test for effects on seedling growth. Germination and establishment of wetland vegetation was successful at both sites within 2 months and the wet meadows in particular were heavily vegetated with a diverse mix of wetland plant species for the 3 years following planting. Fluctuating

3: Bess, J. and R. Chimner. 2015. A Novel Approach to Establishing Coastal Wetlands on the Southern Shore of Lake Superior. Manuscript. 
water levels and the addition of peat moss influenced vegetative growth and survival. Costs were minimal compared to nursery stock, with our seed and labor costs totaling $\$ 2,298$ for both sites, one-quarter or less of the cost of using nursery stock.

\subsection{Introduction}

Coastal wetlands exist at the terrestrial-aquatic interface where they provide critical habitat and perform invaluable ecosystem functions. In addition, coastal wetlands are hotspots for primary production, which directly and indirectly enhances habitat and secondary production for a diverse array of fish and wildlife (Jude and Pappas 1992, Prince et al. 1992, Brazner 1997, Tanner et al., 2004, Sierszen et al. 2006, Timmermans et al. 2008, Urizarski et al., 2008). They also provide enormous value by protecting shorelines from erosion and filtering nutrients and sediments before they enter aquatic systems (Mitsch and Wang 2000, Kriegger 2003). Pristine coastal wetlands also maintain very high degrees of biological diversity, especially with regards to species of conservation concern (Christie and Bostwick 2012, Albert, 2003, Denny, 1994).

Fresh-water coastal wetlands once covered more than 424,000 hectares in the Great Lakes Basin (U.S. EPA, 2009). Since Europeans began modifying the regional landscape in the early 1800 's, more than $50 \%$ of these wetlands have been destroyed, with an estimated 214,000 hectares remaining (U.S. EPA, 2009). Many of these remaining wetlands are degraded or facing on-going threats such as coastline hardening (placing of rip-rap or seawalls), dredging and channelization, agricultural runoff, climate change and invasive species (Kling, et al., 2003, Dahl and Stedman, 2013). Dahl and 
Stedman estimate that 20-30,000 hectares of Great Lakes coastal wetlands were lost between 1978 and 2005 alone (and long after legislation was passed to ensure their protection). These losses and continuing degradation have had catastrophic effects on fisheries, waterfowl populations, water quality and biodiversity (Albert, 2003; U.S. EPA, 2009; Danz et al. 2007; Dahl and Stedman, 2013). Being cognizant of these losses and their effects on the regional environment and local economies, the U. S. and Canadian governments have instituted programs to catalog remaining wetlands, identify the threats they face and institute restoration projects (US EPA, 2009; Dahl and Stedman, 2013).

In the past few decades, numerous projects have been undertaken to restore Great Lakes coastal wetlands, but results have been inconsistent or unknown due to lack of sufficient monitoring (Wilcox and Whillans 1999; Mitsch and Wang 2000). There has also been a lack of knowledge transfer to provide practitioners with up-to-date methods. Furthermore, most of these restoration projects have been conducted in the lower Great Lakes, compared to cold northern wetland types as in Lake Superior where much less is known (Wilcox and Whillans 1999).

In the Keweenaw Peninsula, additional wetland acreage was covered with "stamp sand" deposits left over from copper mining in the early and mid-20 $0^{\text {th }}$ century (MIDNR, 1987; Kolak et al. 1998; Kerfoot et al. 1999). The coarse nature of these sands leads to rapid drainage and little retention of organic matter, which inhibits natural wetland regeneration. Our objective was to test the efficacy of using seeds to restore coastal wetlands such as fens. Prior to this research project, Great Lakes coastal wetland restorations used live cuttings or nursery stock for planting (Wilcox and Whillans 1999). 
Two sites were selected that represented the most common conditions currently present on local coastal lands, allowing us to determine if our methodology has potential for widespread application for coastal wetland restoration elsewhere in the Great Lakes. We also wanted to determine if biodegradable geotextile materials were useful in facilitating restoration of coastal wetland vegetation by seeding and whether the addition of organic matter (milled peat moss) enhanced seed germination and seedling establishment.

\subsection{Methods}

\subsubsection{Site Selection and Preparation}

Two Lake Superior coastal sites were selected for restoration on the Keweenaw Peninsula in the western Upper Peninsula of Michigan; the "Marsin Center" (or "Marsin") and "Sand Point" (Figure 4.1). Permission was granted by the property owners and necessary permits were obtained from the U. S. Army Corp of Engineers (USACE) and Michigan Department of Environmental Quality (MDEQ) prior to site preparation and construction of experimental plantings.

\subsubsection{Marsin Center}

The Marsin Center (Marsin) is a property owned by the Keweenaw Land Trust that has over $300 \mathrm{~m}$ of shoreline on the Portage Waterway (lat. $47^{\circ} 10^{\prime} 57.93^{\prime \prime} \mathrm{N}$, long. $88^{\circ}$ $38^{\prime} 0.63 " \mathrm{~W}$, Houghton County, MI). Much of this frontage was likely vegetated with coastal wetlands at the time of settlement and has been filled and converted to residential lawn over the past $\sim 100$ years. Currently, a narrow (1-2 m wide) band of degraded wetland vegetation occurs on the water's edge along much of the frontage. Reed 
canarygrass (Phalaris arundinacea) and spearmint (Mentha x spicata) are common throughout much of this vegetative fringe (Table 1). Prior to restoration, the Marsin restoration site had a narrow ( $1 \mathrm{~m}$ wide) band of wetland and upland vegetation heavily infested with invasive reed canary grass and spearmint. The surface of the site was also raised above the current level of saturated soil by approximately $0.3 \mathrm{~m}$, so we decided to remove the weedy vegetation with an excavator, to expose fresh soil and lower the soil surface to within $2.5-5 \mathrm{~cm}$ of the current level of soil saturation. Appropriate permits

were applied for and received from U. S. Army Corp of Engineers (the Portage Waterway is a regulated U.S. water) and Michigan Department of Environmental Quality (MDEQ) in May of 2010. Individuals of reed canarygrass and tag alder were pulled and removed from the restoration site each summer during this project.

\subsubsection{Sand Point}

The Sand Point site is on the shoreline of a 2.2 hectare pond set in a matrix of stamp sands on Keweenaw Bay Indian Community (KBIC) property along Keweenaw Bay (46 47' 21.54" N 88²7' 49.65" W, Baraga County, MI). These stamp sands were recently (2008) capped with mineral subsoil as part of a U. S. EPA-funded Superfund Site restoration (Nankervis, 2012). Scattered clumps of wetland plants occur along the shoreline, primarily necklace sedge (Carex projecta), needle spikerush (Eleocharis acicularis), common rush (Juncus effusus) and other rushes (Juncus spp). High quality coastal fens occur immediately to the west and north of the pond, which was also likely an interdunal wetland/coastal fen prior to human alteration. 
The soil cap on the stamp sands had previously been seeded with Eurasian pasture species including fescue (Festuca arundinacea), sheep fescue (F. trachyphylla), bird'sfoot trefoil (Lotus corniculatus), black medic (Medicago lupulina), alfalfa (M. sativa) and clovers (Trifolium spp.) and these were growing in the upper third of the restoration site. Given the recent capping of the stamp sands, no attempt was made to lower the soil surface or scrape away the non-native vegetation. The site was selected based on low slope, the relative lack of vegetative cover and obvious signs it had recently been under water (drift line, scattered clumps of wetland vegetation, band of wetland spikerush (Eleocharis flavescens) along the former high water mark). To minimize cover by nonnative upland species, all individuals of alfalfa, bird's-foot trefoil and black medic were cut off at soil surface during seed set and removed from the restoration area following vegetation data collection in late summer of 2010, 2011 and 2012.

\subsubsection{Experimental Design}

At each of the two sites selected for coastal restoration (Marsin and Sand Point), a $33 \mathrm{~m}$ long by $4 \mathrm{~m}$ wide sector of shoreline was selected and subdivided into three zones: emergent, wet meadow and shrub (Figure 4.2). The emergent and shrub zone fen meadow plots were of two, alternating types, those with an organic soil amendment (5 each per zone) and those without (5 each per zone). The organic soil amendment consisted of milled Sphagnum peat moss.

The emergent zones consisted of 10, 3 m long x $0.3 \mathrm{~m}$ diameter "coir logs". Coir logs were made from a 3 x 3 meter section of coir matting (made from coconut husk 
fibers - Bio D-Mat 70 ${ }^{\mathrm{TM}}$ (Rolanka Corporation, Georgia, USA)) overlaid with a $1.5 \times 3$ meter section of jute matting (made from fibers of a plant in the family Malvaceae) and then rolled tightly, lengthwise, to form a cylindrical "log". For the peat-treated logs, a 5 $\mathrm{cm}$ layer of milled peat moss was applied over the jute matting prior to rolling. Seeds

were placed inside the outermost layers of coir and jute matting on the top side of the log by placing logs with the final flap of fabric on top and then folded back allowing seeds to be placed inside the outermost layers. For peat-treated logs, seeds were scattered on top of the peat and the coir/jute matting then placed back over them. Logs were then put in a linear arrangement at the current waterline, with the seeded section up, and secured in place with $1.3 \mathrm{~m}$ pieces of rebar and wire.

The fen meadow zone was a $3 \times 33 \mathrm{~m}$ area immediately inland and adjacent to the emergent zone and divided into 10, 3 × $3 \mathrm{~m}$ restoration plots, lining up with each of the emergent coir logs. Seeds were placed directly onto the soil and covered in a $3 \times 33 \mathrm{~m}$ section of coir material, underlain with a 3 x 33 m layer of jute fiber matting. For the peat treated plots, $5 \mathrm{~cm}$ of peat was placed over the soil surface and seeds broadcast over the peat surface before being covered with geotextile layers. The shrub zone consisted of an additional row of $3 \mathrm{~m} \times 0.3 \mathrm{~m}$ diameter coir logs constructed as in the emergent zone, and laid immediately upslope and adjacent to the wet meadow zone (Figures 4.3 and 4.4).

\subsubsection{Seed Stock and Treatment}

A total of 380 grams of seed from 47 species of wetland plants native to the Keweenaw Peninsula were collected for use in this project (Table 4.1). All seeds were 
hand collected from August through October of 2009 and obtained within a $40 \mathrm{~km}$ radius of the restoration sites. Seeds of shrubs were retted and scrubbed through screens to remove all fruit pulp and to lightly scarify the seed coat. In the case of chokeberry (Aronia melanocarpa), we were unable to efficiently separate the seed from the fruit pulp, so the entire mix was sifted to the smallest possible grain size without damaging the seeds themselves. For planting purposes, Aronia seed/pulp mix was applied (at a rate of $30 \%$ seed per unit weight/volume). All other shrubs were planted as near pure live seed.

Carex spp., Iris and Juncus spp. were all planted as near pure cleaned seed. Iris had seed predation from the flag weevil (Monomychus vulmeculus) that approached $10 \%$. Seed were hand cleaned to remove all living weevil larvae and pupae from the seed and remove much of the damaged seed. No insecticide was applied to avoid any future adverse effects on the developing plant and insect community once the restorations were planted and becoming established. Iris seed was applied at an increased rate to account for potential inclusion of damaged seed. With the Asteraceae, the pappus was left on the seeds in all species used. This facilitated mixing of seeds and the pappus retained minute seeds such as those of Eleocharis, Scirpus and Juncus, allowing for more even mixing and distribution of seed.

Following cleaning, sorting and weighing, seeds were stored cold and dry in a refrigerator for 6 months until April 15 of 2010, when cold stratification commenced. Identical seed mixes were weighed out for each of the treatment plots in each of the three zones at the two sites. The seeds were mixed with $946 \mathrm{~cm}^{3}$ of dry Vermiculite, $250 \mathrm{ml}$ of very warm ( $\sim 33$ degrees $C$ ) water and $10 \mathrm{ml}$ of liquid fungicide (Dalconex). The seed, 
vermiculite, water and fungicide were then thoroughly mixed in a one-gallon Ziploc bag and the bags sealed and placed warm in a cooler for 24 hours before being placed in a refrigerator at 3.3 degrees $\mathrm{C}$ for 3 months of cold stratification. This was done to maximize the saturation of hydrophobic Carex perigynia and thick seed coats in other species.

\subsubsection{Zone Construction and Seeding}

The coir "logs" used in this experimental planting differ from pre-made ones available from manufacturers. We made our own logs by tightly rolling $3 \mathrm{~m}$ square sectors of Bio D-Mat $70^{\mathrm{TM}}$ coir material, lined with a $3 \mathrm{~m}^{2}$ piece of jute fiber matting, into a $3 \mathrm{~m}$ long by $0.3 \mathrm{~m}$ diameter, tubular, "log" in which seeds were then placed. For the logs with organic (peat) addition (hereafter referred to as "peat logs"), milled peat moss was spread over the $3-\mathrm{m}$ square coir-jute mat to a depth of $5 \mathrm{~cm}$ prior to rolling. Seeds were placed inside the outer layers of matting prior to placement and the entire log was secured in place with 15 -gauge wire and $1.3 \mathrm{~m}$ sectors of rebar, driven into the substrate. The $30 \mathrm{~cm}$ diameter seeded logs were placed so that the seeded portion was on the top and placed so they were partially submerged, with the tops approximately $15 \mathrm{~cm}$ above the waterline (at that time). Seeds from 19 species of emergent wetland plants were used in restoration of the emergent zone (Table 4.1).

As with the emergent zone, the fen meadow zone had alternating treatments of organic soil amendment vs no amendment. Seed from 36 species of wetland plants (Table 4.1) were hand-broadcast across each of the $3 \mathrm{~m} \times 3 \mathrm{~m}$ wet meadow restoration 
plots. For planting, the bags of seed mix were placed in a cooler for transport to the restoration site. Immediately prior to planting, a bag of seed/vermiculite mix was poured into a 7.56 liter plastic bucket and then further mixed by hand, to break up clumps of seed and make the mixture as homogeneous as possible. In the case of the coir logs, of a 0.5 $m$ flap of coir-jute matting pulled back and the seed mix was then spread evenly over the top of the exposed sector of log. Following seed placement, the flap of matting was placed over the seeds and the log secured in place with rebar and wire. In the case of the logs with peat amendment, the seeds were placed on top of the milled peat moss and the flap of matting replaced as with the untreated logs. For the wet meadow zone, seed mix was broadcast evenly over each of the $3 \mathrm{~m} \times 3 \mathrm{~m}$ restoration plots and, as with the coir logs, seed was placed on top of the milled peat moss. For the organic amendment plots (hereafter referred to as "peat plots"), seed was placed on top of the milled peat moss, prior to covering with the jute-coir mat layer. Immediately upslope from, and adjacent to the fen meadow, another linear arrangement of $3 \mathrm{~m}$ long by $0.3 \mathrm{~m}$ diameter coir logs was used to form a shrub zone. Like the emergent zone, alternate logs in the shrub zone had peat added to them and were planted with seeds of 11 native wetland trees and shrubs (Table 4.1), using the same technique as for the emergent zone logs. For each set of emergent log, fen meadow plot and shrub zone log, they had matching treatments; the first set were all treated with peat, the second set no peat, the third set with peat and so on (Figure 4.2). Both sites were constructed and seeded in late June, 2010 (Figures 4.3, 4.4).

Given that it is a common component of coastal wetlands in the upper Great Lakes region, and was not included in our seed mix, 1,200 bare root Carex stricta culms 
were planted, 600 in the wet meadow zones at each of the two restoration sites in May of 2011. Each wet meadow was subdivided into 3 "sectors" parallel to the water's edge. The culms were planted in pairs, 10 pairs per sector in each plot at each site $(200$ culms total per sector, 600 culms total per site). Sectors were parallel to the emergent zone logs; 1.) "lakeside" (0.3 m from the emergent zone coir logs), 2.) "middle" (halfway between lake side and upper edges $)$ and 3.) "upper" (0.3 m from upper edge of meadow plot). These sectors were also used for vegetation sampling from 2010 to 2013.

\subsubsection{Vegetation Sampling}

One-third square meter vegetation sampling plots $\left(0.3 \mathrm{~m}^{2}\right)$ were made out of 1.25 cm diameter polyvinylchloride pipe and used to gather vegetation data on both the coir logs and wet meadow restoration plots (Figure 4.5). Sampling quadrats were placed every $0.6 \mathrm{~m}$, starting $0.3 \mathrm{~m}$ in from the southern edge of each log/plot and ending $0.3 \mathrm{~m}$ before the north end/edge of each log/plot. Five subsamples were collected from each emergent zone and shrub zone coir log and data on vegetative cover and diversity were recorded on standardize data sheets. For the fen meadow plots, subsample collection was repeated 3 times, once in each of the three sectors (lakeside, middle and upper), for a total of 15 subsamples for each wet meadow restoration plot. Plants were identified to species whenever possible, although many vegetative sedges, grasses and young mosses could only be determined to genus. Voss' three-volume "Michigan Flora" (Voss, 1972, 1985, 1996) was used for determinations and the most recent names of our flora were obtained 
from Voss and Reznicek (2012) and the USDA PLANTS Database (USDA-NRCS, 2012).

Vegetative cover was estimated visually to the nearest percentage. Cover was assessed on a per-species or taxon basis and, given the multiple strata of plant growth, total vegetative cover for individual quadrats could exceeded $100 \%$ when values for individual species/taxa were tallied together. Data on species richness was collected at the subsample level for use in later analysis and consisted of tallies of taxa (usually identified to species) for each subsample. Subsample cover and species richness data were combined to give average values for individual logs and fen meadow sectors, treatments and plots. The subsample data were also combined to give cover and richness information for treatments (peat vs no peat) and entire zones (emergent, fen meadow, shrub meadow). Carex stricta survivorship was measured as at least 1 culm remaining green in the late summer of 2011.

\subsubsection{Statistical Analysis}

We compared total vegetative cover and species richness in the wet meadow zone between the 3 sectors (lakeside, middle and upper) and treatments (peat vs no peat). Percent cover of individual plant taxa was also compared among treatments and sectors. Analysis of variance (nested ANOVA) was used to determine whether there were significant differences in the variation of vegetative cover among the sectors and treatments. P-values $\leq 0.05$ were considered statistically significant. SAS software (Proc-ANOVA, SAS Institute, Inc., Cary, NC) was used to calculate ANOVA's. 


\subsection{RESULTS}

\subsubsection{Water Levels in Lake Superior}

In the spring of 2010, mean water levels in Lake Superior (and thus the Portage Waterway and Lake maintained pond at Sand Point) were nearly $20 \mathrm{~cm}$ below the 154 year average of $183.3 \mathrm{~m}$ above mean sea level (msl). This trend continued from spring 2011 until July, 2013 (Figure 4.5). Water levels in Lake Superior typically cycle annually, with higher water levels in summer and lower in early spring (March-April; NOAA, 2015). However, during the spring 2011-2013 seasons, reduced snow pack and minimal spring rainfall intensified this cycle and some of the lowest spring water levels in the past 20 years occurred in 2011-2013. Increased rainfall in the summer of 2013 led to a rise in lake levels and abundant snowfall in the winter of 2013-2014 caused Lake Superior water levels to reach their long-term (154 year) average in summer of 2014 (Figure 4.5).

\subsubsection{Marsin Center}

\subsubsection{Overview}

The Marsin wetland restoration had a variable response to fluctuating water levels over the four years of this study. In 2010, there was extensive germination of wetland seeds in the emergent and wet meadow zones within 2 weeks of planting (Figures 4.6A and 4.6B), yet none in the shrub zone. Seedlings formed an extensive carpet of vegetation underneath the coir-jute matting in the fen meadow zone and on the tops of the emergent zone coir logs. However, the continued drought (and lake level drop) during 
2011-2012 resulted in the death of the seedlings in the exposed emergent zone logs in 2011 (Figure 4.7A). Consequently, while seedling establishment in the shrub zone coir logs didn't occur, rainfall and wave action apparently washed seeds out of these logs and deposited them behind and underneath, where they germinated and shrubs became established. The soil in the wet meadow zone remained moist and resident vegetation was dense and diverse throughout the course of this study.

\subsubsection{Vegetation - 2010}

Seedlings were observed within 2 weeks following planting, resulting in a carpet of young plants under the coir-jute matting in the fen meadow zone by the end of summer (Figures 4.6A-C). The emergent zone logs also had a dense cover of young sedges, bulrushes and other monocots by late summer of 2010 (Figure 4.6A, Tables 4.3A, 4.4). The no peat logs had a slightly greater cover of vegetation ( $26 \%$ vs $19 \%$ on the peat logs, Tables 4.3A, 4.4) but richness was identical (6 species each treatment, Table 4.5). Iris versicolor had the greatest cover ( $16 \%$ no peat vs $10 \%$ peat, Table 4.5$)$, followed by Carex spp. (4\% each) and Juncus spp. (4\% no peat vs $2 \%$ in the peat logs).

Vegetative cover within the fen meadow zone was well-established in all three sectors (lakeside, mid-plot and upslope). Total vegetative cover values ranged from $25 \%$ in the no peat lakeside sector, to $47 \%$ in the peat lakeside sector. The peat treated plots had the greatest vegetative cover in the lakeside sector (47\%), while the no peat had the greatest cover in the middle sector (39\%). Averaged across the three sectors, overall 
vegetative cover was $43 \%$ in the peat plots and $34 \%$ in the no peat plots (Figure 4.9 , Tables 4.3A, 4.4).

Wetland plant species richness was nearly identical among the two treatments, with 26 species in the peat plots and 25 species in the no peat, for a total of 28 wetland plant species in the fen meadow zone (Table 4.5). The emergent logs were also nearly identical in species presence, with 10 species total for the peat and 9 on the no peat logs (Table 4.5). In the fen meadow, Carex spp. had the greatest average cover $(20 \%$ in the peat plots vs $14 \%$ in the no peat), followed by Bidens frondosa ( $6 \%$ vs $4 \%$ ), Juncus spp. (4\% vs 5\%), forb seedlings (4\% each), Doellingeria umbellata (2\% vs 3\%). Iris versicolor and Scirpus spp. provided 1\% cover in each treatment, while Asclepias incarnata, Lycopus spp. and Phalaris arundinacea provided 1\% cover in the peat plots, but less than $1 \%$ in the no peat (Table 4.4). Conversely, Thalictrum dasycarpum provided $1 \%$ cover in the no peat plots but less than $1 \%$ in the peat. All other species provided less than $1 \%$ cover across all plots. In the emergent logs, "Iris versicolor" (including at least some Sparganium spp. seedlings) had the greatest cover $(10 \%$ in the peat logs, $16 \%$ in the no peat logs). This was followed by Carex spp. cover ( $4 \%$ each log type) and Juncus spp. (2\% and 4\%, respectively). 


\subsubsection{Vegetation - 2011}

Continued lowering of Lake Superior water levels resulted in the death of all seedlings in the emergent zone logs at the Marsin site during the winter/spring of 2011 (Figures 4.7A, 4.8A). However, the soil in the fen meadow zone remained moist and the vegetation there continued to grow and increase from the 2010 levels (Figures 4.8C and 4.10, Tables 4.6A). In the fen meadow peat plots, mean vegetative cover was $98 \%$, with a total of 44 species of wetland plants recorded, while in the no peat plots mean cover and species richness were less (78\% and 39 species). The difference in cover was statistically significant between the peat and no peat research plots $(p=0.01$; Table 4.7A). Among both treatments, the middle sector of the fen meadow zone had the greatest vegetative cover $(102 \%$ in the peat plots and $87 \%$ in the no peat). In the peat plots, vegetative cover was lowest in the upper sector $(83 \%)$, while in the no peat plots, vegetative cover was lowest in the lakeside sector (72\%).

Among both treatments, Carex spp (39\% peat vs 29\% no peat), Juncus spp. (19\% vs $16 \%$ ) and Doellingeria umbellata (6\% each) provided the greatest cover (Table 4.8$)$. In the peat plots, the next greatest cover values were for Iris versicolor (6\%), Solidago uliginosa (5\%) and Bidens frondosa (4\%). The invasive Phalaris arundinacea was still prevalent in the peat plots and cover had increased from 2010 (nearly $2.5 \%$ vs $1 \%$ in 2010). In the no peat plots, the next greatest cover values were for Solidago uliginosa and Lycopus spp. (4\% each) and Iris versicolor and Bidens frondosa (nearly 3\% each). Phalaris arundinacea was also present, but with a slightly lesser cover $(\sim 1.8 \%)$ than in the peat plots. Vegetative cover in the peat plots was still significant greater than in the 
no peat ones in 2011 (Table 4.6A - 4.8). Plant diversity was also significantly different among both treatments and sectors, with the peat treated middle sectors having the greatest diversity of wetland plants (Table 4.9). Carex stricta survivorship varied between treatments, with the no peat plots having greater average survivorship across all sectors. Survivorship among the sectors were nearly identical in the non-treated plots, while the peat plots had greater average survivorship in the upper sector which was the same as the no peat plots (33, Table 4.10A).

\subsubsection{Vegetation - 2013}

Lake level rose markedly in 2013, increasing $40 \mathrm{~cm}$ from January through August (Figure 4.5), and completely inundating the coastal wetland restoration at Marsin (Figures 4.10, 4.11). Vegetative cover and species composition changed in response to the rise in lake level (Figure 4.11, Table 4.6A). The no peat plots had the greatest cover and richness of wetland plants $(76 \%$ cover and 40 species vs $65 \%$ cover and 35 species in the peat plots). Juncus spp. remained the dominant cover, with $28 \%$ cover in the peat plots and $29 \%$ in the no peat. Carex spp. had the second greatest cover with $9 \%$ in the peat plots and $14 \%$ in the no peat, followed by Iris versicolor (7.3\% vs 5.4\%), Solidago uliginosa (3.4\% vs 5.0\%), Doellingeria umbellata (3.19\% vs 4.91\%), Myrica gale (3.7\% vs 3.5\%), Lycopus spp. (2.1\% vs 4.1\%), Calamagrostis canadensis (1.6\% vs 1.9\%) and Eupatorium maculatum (1.1\% vs 1.7\%).

Phalaris arundinacea was still prevalent, with $1.4 \%$ cover in the peat plots and $2.6 \%$ cover in the no peat. Plant diversity changed over time (Figure 4.13 ) and by 2013, 
the peat plots had 13 wetland plant taxa with $1 \%$ cover or greater, while the no peat had 15 taxa with $1 \%$ cover or greater. Mean vegetative cover across the two treatments was $70 \%$ with an overall richness of 40 wetland plant taxa. There were statistically significant differences in vegetative cover between the two treatments, with the no peat plots having slightly greater cover. The no peat lakeside and upper sectors had the greatest vegetative cover ( $88 \%$ and $83 \%$ cover, respectively; Table 4.4 ).

\subsubsection{Sand Point}

\subsubsection{Overview}

Like the Marsin Center site, Sand Point showed a variable response in vegetation establishment among the experimental treatments - the emergent logs and wet meadow plantings grew fairly well, while those in the shrub zone did not. The dense cover of Eleocharis acicularis and upland pasture species (already present on-site at planting time) may have impeded seedling establishment in some areas. Evidence of muskrat (Ondatra zibethicus) and Canada geese (Branta canadensis) grazing on plants in the restoration was evident in the first year and throughout this study. This became much more evident in 2013, when muskrats began tunneling under the coir matting, making large trenches in the planting area. Despite this, vegetation continued to grow and spread, although certain species disappeared as a result of continued grazing, particularly pickerelweed (Pontederia cordata) and broadleaf arrowhead (Sagittaria latifolia). 


\subsubsection{Vegetation - 2010}

Seedlings became apparent within 2 weeks of planting and had covered the tops of the emergent logs and saturated portions of the wet meadow plots (Figure 4.5D). On the emergent logs, the peat treated plots had substantially greater vegetative cover than the no peat plots (58\% vs 19\%, respectively; Figure 4.8). In both the peat and no peat treated logs, Carex spp., (12\% vs 5\%), Eleocharis sp. (1\% vs 2\%), Iris/Sparganium (11\% vs $8 \%$ ) and Scirpus spp. (5\% vs 1\%) were the dominant plant taxa (Figure 4.8, Table 4.2B). Iris and Sparganium cover was combined because of difficulty differentiating young vegetative individuals in the field. We believe Sparganium only occurred in the emergent logs at Sand Point.

In the wet meadow zone, total wetland vegetation cover on the peat plots was $90 \%$ vs $80 \%$ in the no peat plots (Figure 4.7, Table 4.2B). In both treatments, wetland plant cover was greatest in the mid-plot sector, with $142 \%$ cover in the peat and $131 \%$ cover in the no peat plots. Wetland plant species richness was essentially identical between the two treatments, with 27 species in the peat plots and 26 species in the no peat. Eleocharis acicularis dominated both the peat and no peat plots, averaging 39\% and $33 \%$ cover, respectively. Additional wetland plant species cover on both the peat and no peat plots was dominated by Carex spp. (10\% vs 13\%, respectively), undetermined grass spp. (9\%, each), Juncus spp. (11\%vs 13\%), Echinocloa crus-galli (4\% vs 3\%), Asclepias incarnata (2\% vs .24\%) and Bidens frondosus (2.2\% vs 2.5\%). No seedlings were noted in the shrub zone logs. 


\subsubsection{Vegetation - 2011}

The peat treated emergent logs continued to have greater vegetative cover $(55 \%$ vs $33 \%$ ) compared to the ones without peat (Figure 4.11, Table 4.3B). Conversely, the no peat emergent logs had a greater richness of wetland species (15) than the peat treated ones (11). In the wet meadow, vegetative cover was slightly higher in the no peat plots (79\%) than the peat treated ones (71\%). Wetland plant species richness was also slightly higher in the no peat plots ( 27 vs 23 species). Juncus spp. dominated the peat plots (23\%), whereas Eleocharis acicularis still provided the greatest cover in the no peat plots with $27 \%$ cover (followed by Juncus spp. with $20 \%$ cover). Carex spp. continued to provide substantial cover, with $10 \%$ in the peat and $7 \%$ in the no peat plots. Agrostis stolonifera was also common in both treatments, with $7 \%$ cover in the peat and $10 \%$ cover in the no peat plots.

Bidens frondosa was still a major cover component ( $4 \%$ peat vs $3 \%$ no peat), followed by Lycopus spp. (1.7\% vs 2.5\%), Doellingeria umbellata (1.6\% vs 1.1\%), Iris versicolor ( $1.7 \%$ vs $0.6 \%)$, Asclepias incarnata (1.6\% vs $0.4 \%)$ and Thalictrum dasycarpum ( $0.9 \%$ each). The peat treated plots had 12 wetland plant taxa providing greater than $1 \%$ cover, while the no peat plots had only 9 taxa providing greater than $1 \%$ cover. Statistically significant differences in vegetative cover and diversity were found between the two treatments (peat versus no peat) and sectors (Table 4.4). Carex stricta survivorship is given in Table 4.5. 


\subsubsection{Vegetation - 2013}

Rising lake levels in 2013 resulted in inundation of much of the wetland restoration at Sand Point, killing off much of the upland vegetation growing on-site and encouraged the growth of wetland plants (Figures 4.10B, 4.11). The emergent logs were especially thick with vegetation, with $111 \%$ total cover on the peat logs and $89 \%$ cover

on the no peat (Table 4.6B and Figure 4.12). Vegetative cover on the emergent logs was dominated by Carex species (67\% on the peat logs, $51 \%$ on the no peat), with Carex comosa/pseudocyperus being the most prevalent (64\% vs 57\%). Many Carex comosa and C. pseudocyperus were in full fruit at the time of vegetation surveys. Iris versicolor (15\% vs 14\%), Juncus spp. (14\% vs 8\%), Scirpus atrovirens (9\% vs 11\%) and Sparganium spp. were the next most abundant cover species, followed by Scirpus cyperinus (4\% vs $0.8 \%)$ and Eleocharis palustris (0.8\% vs $1 \%)$. All other species provided less than $1 \%$ cover. Total wetland plant richness on the emergent logs (across the two treatments) was 17 species, with 13 species in each treatment (Figure 4.14).

As with the Marsin site, plant diversity at Sand Point changed over time (Figure 4.14). The wet meadow zone had good coverage by wetland plant species, with a total of 36 wetland plant taxa providing an average cover of $48 \%$ across the two treatment types (29 species providing $49 \%$ cover in the peat plots and 28 species with $46 \%$ cover in the no peat). Juncus spp. continued to provide the most cover of any wetland taxa, with $\sim 20 \%$ cover in both treatments. Carex spp. provided the next greatest cover, with $6.7 \%$ across the two treatments ( $7.5 \%$ vs $5.8 \%$, respectively). Carex projecta was the most 
abundant ( $4.7 \%$ cover vs $5.1 \%)$ of these, followed by Carex stricta ( $1.5 \%$ cover vs $.7 \%)$ and Carex comosa $(0.3 \%$ cover vs $0 \%)$.

Additional common cover species included Asclepias incarnata (4.1\% vs $1.7 \%$ ), Scirpus cyperinus ( $2.4 \%$ vs $2.9 \%$ ), Eleocharis palustris ( $2.6 \%$ vs $2.2 \%)$, Lycopus americanus (2.0\% vs $2.1 \%)$, Iris versicolor ( $2.3 \%$ vs $1.4 \%)$, Calamagrostis canadensis ( $1.1 \%$ vs $1.8 \%)$, Agrostis hyemale (0.9\% vs $1.3 \%)$ and Scirpus atrovirens (1.8\% vs $0.0 \%$ ). A notable species that appeared in the plots (but was not in the initial seed mix) was the ladies tresses orchid Spiranthes cernuua, which had a cover of $0.7 \%$ in the peat plots and $0.3 \%$ in the no peat. This fairly common, fall-flowering orchid was observed all around the pond at Sand Point, apparently resulting from seed being blown in from adjacent natural areas. All other plant species occurred at less than 1\% cover. Analysis of Variance found there to still be statistically significant differences in vegetative cover and diversity between the two treatments (peat versus no peat) and sectors (Table 4.4). The peat treatment and middle sector plots had the greatest vegetative cover and diversity in both the 2011 and 2013 samples.

\subsection{Discussion and Implications for Practice}

Despite low lake water levels during much of this study, both restorations were successful in establishing wetland vegetation on two sites that had little prior wetland habitat. The sites selected for this study represent two common coastal situations in the Keweenaw Peninsula; filled, mowed lawns with a mix of wetland plants and non-native

upland species as a fringe along the water's edge and stamp sands resulting from previous 
copper mining activity. The fact that we were successful in establishing fairly diverse wetlands on both site types, in a fairly short period of time, is encouraging for other coastal wetland restoration projects in the region. The combination of using seeds and natural fiber geotextiles worked very well and appears to have been a novel approach, as we could find no other references detailing the use of seeds in establishing wetland vegetation in high wave action, coastal situations. We believe that the initial low water level greatly facilitated the success of these restorations and fluctuating water levels (in conjunction with resident seed banks) are known to be a strong driving force in the maintenance of healthy Great Lakes coastal wetlands (Keddy and Reznicek 1982-1986; Farney and Bookhout 1982; Herrick and Wolf, 2005; Frieswyk and Zedler 2007).

In comparison to the use of nursery stock, seeds can be a very economical alternative for certain coastal wetland restoration projects, especially where wet meadow/fen meadow and emergent vegetation is desired. Plantings during low water level periods would also benefit from the use of seed, mimicking the natural cycle of coastal wetland development and maintenance. For this project our total costs for seed and labor for planting totaled $\$ 2,297.50$. For a minimal density planting of nursery stock at 5 plants $/ 0.3 \mathrm{~m}^{2}$ (45 plants per $\mathrm{m}^{2}$ ), we would have needed 4,550 plants per site or 9,100 plants total. At a cost of $\$ 1.00 /$ plant, this would have been $\$ 9,100.00$, not including delivery and handling. Labor costs would also have been high. At a fast planting rate of 120 plants per hour, this would have required 75.83 hours and, at an hourly rate of $\$ 10.00$, cost an additional $\$ 758.30$, for a total cost of $\$ 9,858.30$ (both sites included). 
This is more than 4 times the cost of seeding and would have resulted in a less dense and less diverse wetland planting.

The addition of peat to half of the plots and geotextile logs had mixed effects on vegetative cover and plant species richness. In the wet meadow zones at both sites, the peat and no peat plots had very similar vegetative cover and wetland plant species richness values. However, in the emergent logs at Sand Point (the emergent logs at the Marsin site did not survive the drought), there was a marked difference in vegetative cover between the peat and no peat treatments, throughout the course of the study. The peat treated logs had a greater vegetative cover and this may have been purely mechanical (the peat held seeds in place), biological (the peat provided additional nutrients that encouraged plant growth) or some combination of the two.

Among the three sectors sampled in the wet meadow zone, the median sector had the greatest vegetative cover and plant species richness throughout the course of this study. This was likely a result of minimal wave action in this zone, which likely removed a substantial portion of seed and young seedlings from the lakeshore sectors at both sites. The upper sector at Marsin was similar in cover and diversity, likely because of the minimal slope at this site and the moist soil conditions throughout the study. The upper sector at Sand Point was fairly dry from 2010-2012, only becoming more moist in 2013 when Lake Superior water levels rose substantially. The lakeshore sector at Sand Point was heavily grazed by muskrats and Canada geese, which negatively affected plant species diversity and vegetative cover. 
The emergent logs were successful in initially establishing vegetation at both sites, but the continued drought killed off the seedlings at the Marsin site. For future restorations using this technique, it is recommended that the logs be embedded into the substrate (if possible), to minimize desiccation during low water periods. The same recommendation goes for the shrub zone geotextile logs, as these remained dry at both sites throughout 2010-2012. Logs might not be acceptable for some sites where drying of the substrate is an issue. For sites with wetland herbivore populations, efforts to protect plantings (particularly emergent plantings) such as fencing or other obstructions are recommended to allow vegetation to establish and spread.

\subsection{Acknowledgements}

We would especially like to thank Michigan Technological University, USEPA and MIDEQ for providing funding for this study. We would also especially like to thank the Keweenaw Land Trust and Keweenaw Bay Indian Community for providing sites for us to use for our wetland restoration experiments. Laura Kangas provided invaluable assistance in helping collect, process, weigh and sort seeds and construct the restorations. Jennifer Bush assisted with constructing the restorations and collecting vegetation data, along with Rose Schwartz. Arvo Aljaste, Ellen Beller, John Hribljan and Margus Pesaelu also provided invaluable assistance in constructing the restorations. 


\subsection{Literature Cited}

Albert, D. 2003. Between land and lake: Michigan's Great Lakes coastal wetlands. Michigan State University Extension: Michigan Natural Features Inventory, East Lansing, MI. MSU Extension Bulletin E-2902. 96 pp.

Brazner, J. 1997. Regional, habitat, and human development influences on coastal wetland and beach fish assemblages in Green Bay, Lake Michigan. Journal of Great Lakes Research 23: 36-51.

Christie, J. and P. Bostwick. 2012. Climate Change Adaptation Plan for Coastal and Inland Wetlands in the State of Michigan. A White Paper Prepared for the Michigan Department of Environmental Quality Wetlands Program and Coastal Management Program. 37 pages.

Dahl, T. and S. Stedman. 2013. Status and trends of wetlands in the coastal watersheds of the Conterminous United States 2004 to 2009. U.S. Department of the Interior, Fish and Wildlife Service and National Oceanic and Atmospheric Administration, National Marine Fisheries Service. (46 p.)

Danz, N., G. Niemi, R. Regal, T. Hollenhorst, L. Johnson, J. Hanowski, C. Johnston, R. Axler, J. Ciborowski, T. Hrabik, V. Brady, J. Kelly, J. Brazner and R. Howe. 2007. Integrated measures of anthropogenic stress in the U.S. Great Lakes Basin. Environmental Management 39: 631-647.

Denny, P. 1994. Biodiversity and wetlands. Wetlands Ecology and Management 3: 5561. 
Farney, R. and T. Bookhout. 1982. Vegetation changes in a Lake Erie marsh (Winous Point, Ottawa County, Ohio) during high water years. Ohio Journal of Science $82: 103-107$.

Frieswyk, C. and J. Zedler. 2007. Vegetation Change in Great Lakes Coastal Wetlands: Deviation from the Historical Cycle. Journal of Great Lakes Research 33:366380.

Herrick, B. and A. Wolf. 2005. Invasive plant species in diked versus undiked Great Lakes wetlands. Journal of Great Lakes Research 31:277-287.

Jude, D. and J. Pappas. 1992. Fish utilization of Great-Lakes coastal wetlands. Journal of Great Lakes Research 18: 651-672.

Keddy, P. and A. Reznicek. 1986. Great Lakes vegetation dynamics: the role of fluctuating water levels and buried seeds. Journal of Great Lakes Research $12: 25-36$.

Keddy, P. and A. Reznicek. 1985. Vegetation dynamics, buried seeds, and water level fluctuations on the shorelines of the Great Lakes. In Coastal Wetlands, eds. H.H. Prince and F.M. D’Itri, pp. 35-58. Chelsea, Michigan: Lewis Publishers, Inc.

Keddy, P. and A. Reznicek. 1982. The role of seed banks in the persistence of Ontario's coastal plain flora. American Journal of Botany 69:13-22.

Kerfoot,W., S. Harting, R. Rossmann, and J. Robbins. 1999. Anthropogenic Copper Inventories and Mercury Profiles from Lake Superior: Evidence for Mining Impacts. Journal of Great Lakes Research 25(4):663-682. 
Kling, G., K. Hayhoe, L. Johnson, J. Magnuson, S. Polasky, S. Robinson, B. Shuter, M. Wander, D. Wuebbles, D. Zak, R. Lindroth, S. Moser and M. Wilson. 2003. Confronting Climate Change in the Great Lakes Region: Impacts on our Communities and Ecosystems. Union of Concerned Scientists, Cambridge, Massachusetts, and Ecological Society of America, Washington, D.C.

Kolak, J., D. Long, T. Beals, S. Eisenreich and D. Swackhamer. 1998. Anthropogenic inventories and historical and present accumulation rates of copper in Great Lakes sediments. Applied Geochemistry 13:59-75.

Krieger, K. 2003. Effectiveness of a coastal wetland in reducing pollution of a Laurentian Great Lake: Hydrology, sediment, and nutrients. Wetlands 23: 778791.

MDNR. 1987. Michigan DNR Remediation Plan for Torch Lake AOC. Surface Water Quality Division, GLEAS. Lansing, MI.

Mitsch, W. and N. Wang. 2000. Large-scale coastal wetland restoration on the Laurentian Great Lakes: Determining the potential for water quality improvement. Ecological Engineering 15: 267-282.

Nankervis, P. 2012. Sand Point Wildlife Habitat Restoration: FINAL Report. USEPAGreat Lakes Restoration Initiative Grant No. GL00E00588-0. Keweenaw Bay Indian Community.

National Oceanic and Atmospheric Administration (NOAA). 2015. Great Lakes Water Level Dashboard. http://www.glerl.noaa.gov/data/dashboard/GLWLD.html 
Prince, H., Padding, P. and R. Knapton. 1992. Waterfowl use of the Laurentian GreatLakes. Journal of Great Lakes Research 18: 673-699.

Sierszen, M., G. Peterson, A. Trebitz, J. Brazner and C. West. 2006. Hydrology and nutrient effects on food-web structure in ten Lake Superior coastal wetlands. Wetlands 26: 951-964.

Tanner, D., J. Brazner, V. Brady and R. Regal. 2004. Habitat associations of larval fish in a Lake Superior coastal wetland. Journal of Great Lakes Research 30: 349359.

Timmermans, S., S. Badzinski and J. Ingram. 2008. Associations between breeding marsh bird abundances and Great Lakes hydrology. Journal of Great Lakes Research 34: 351-364.

Urzarski, D. G., T. M. Burton, J. C. Brazner, and J. J.H. Ciborowski. 2008. Invertebrate Community Indicators. in Burton, T. M. et al. (eds.). Great Lakes Coastal Wetlands Monitoring Plan. Great Lakes Coastal Wetlands Consortium.

USDA, NRCS. 2012b. The PLANTS Database (http://plants.usda.gov, 15 August 2012). National Plant Data Team, Greensboro, NC 27401-4901 USA.

U. S. EPA. 2009. State of the Great Lakes 2009. U. S. Environmental Protection Agency and Environment Canada Report. 437 pages.

Voss, E. 1996. Michigan Flora: Dicots (Pyrolaceae-Compositae). Cranbrook Institute of Science.

Voss, E. 1985. Michigan Flora: Dicots (Saururaceae-Cornaceae). Cranbrook Institute of Science. 
Voss, E. 1972. Michigan Flora: Gymnosperms and monocots. Cranbrook Institute of Science.

Voss, E. and A. Reznicek. 2012. Field Manual of Michigan Flora. The University of Michigan Press, Ann Arbor, Michigan. 990 pages.

Wilcox, D. and T. Whillans. 1999. Techniques for Restoration of Disturbed Coastal Wetlands of the Great Lakes. Wetlands 19: 835-857. 


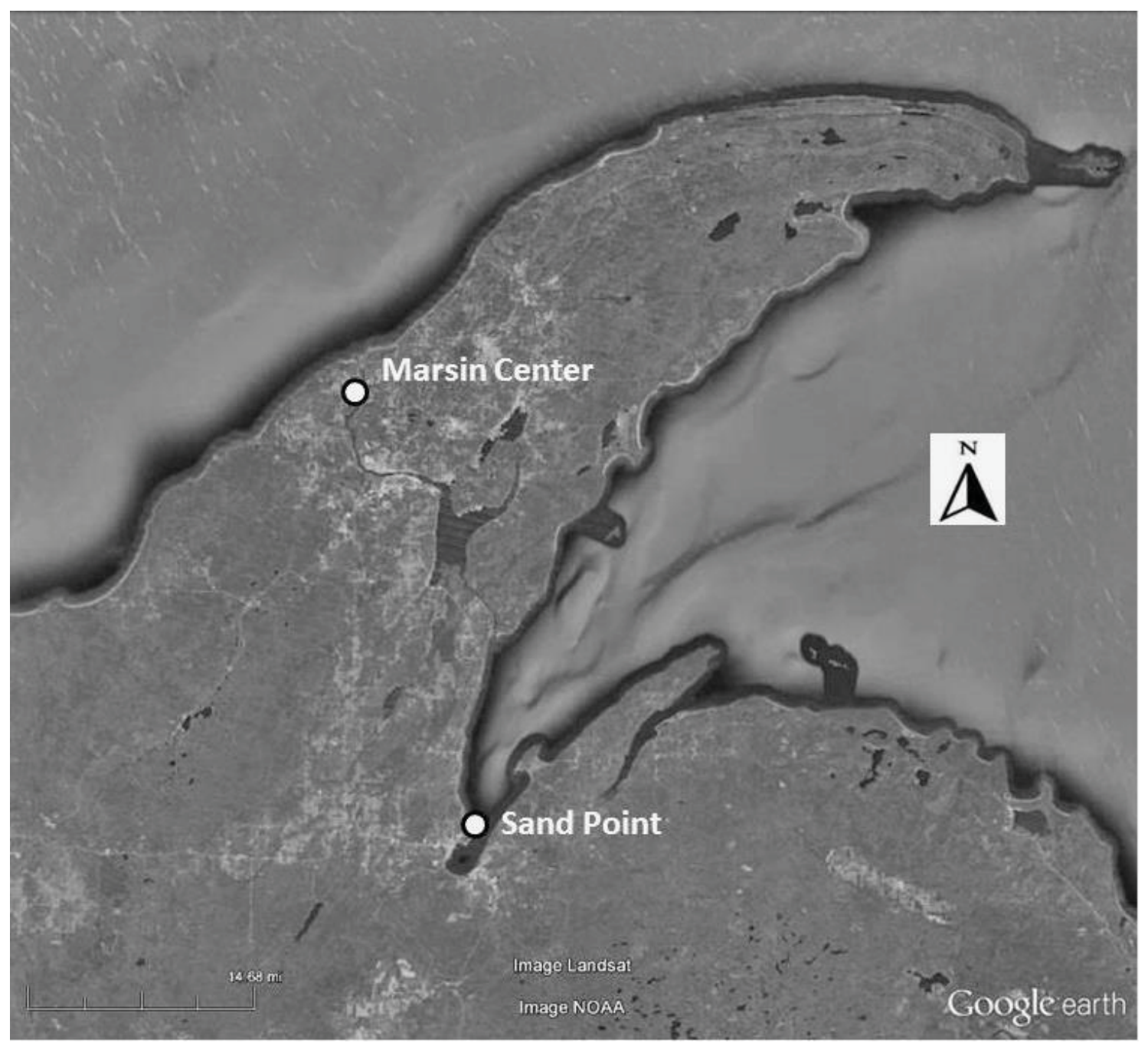

Figure 4.1. Map of the Keweenaw region of Michigan's western Upper Peninsula showing Marsin (upper) and Sand Point (lower) restoration sites. Source: "Keweenaw Peninsula." 47 3'2.28" N and 88 19'15.68" W. Google Earth. August 2014. Accessed April 21, 2015. 


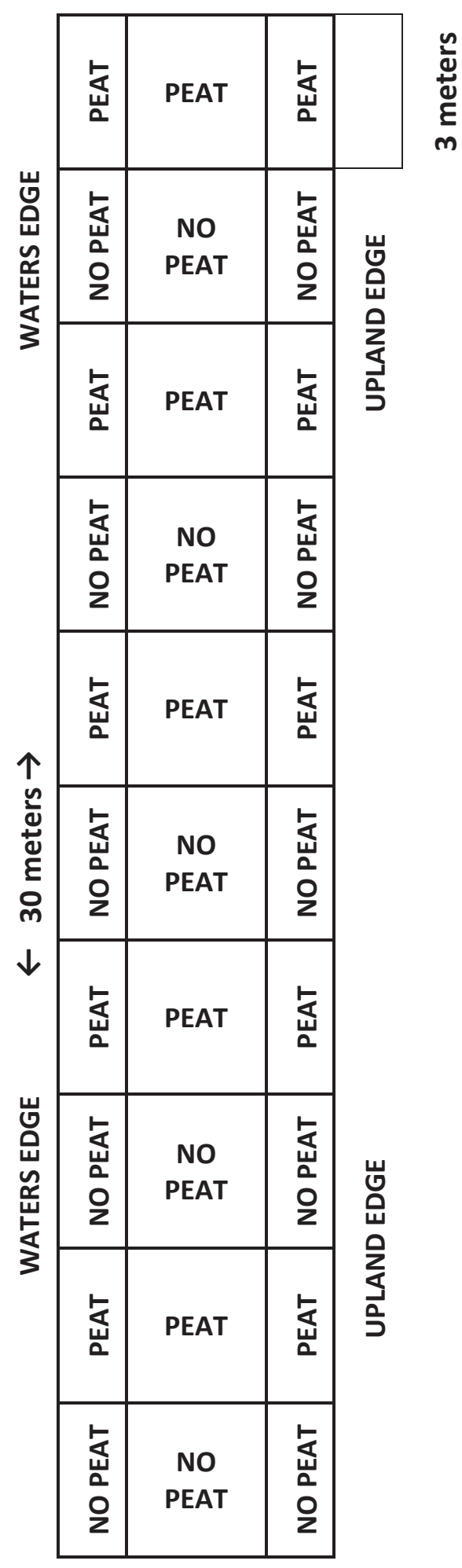

Figure 4.2. The experimental design used at the Marsin and Sand Point restoration sites in Michigan's western Upper Peninsula. 


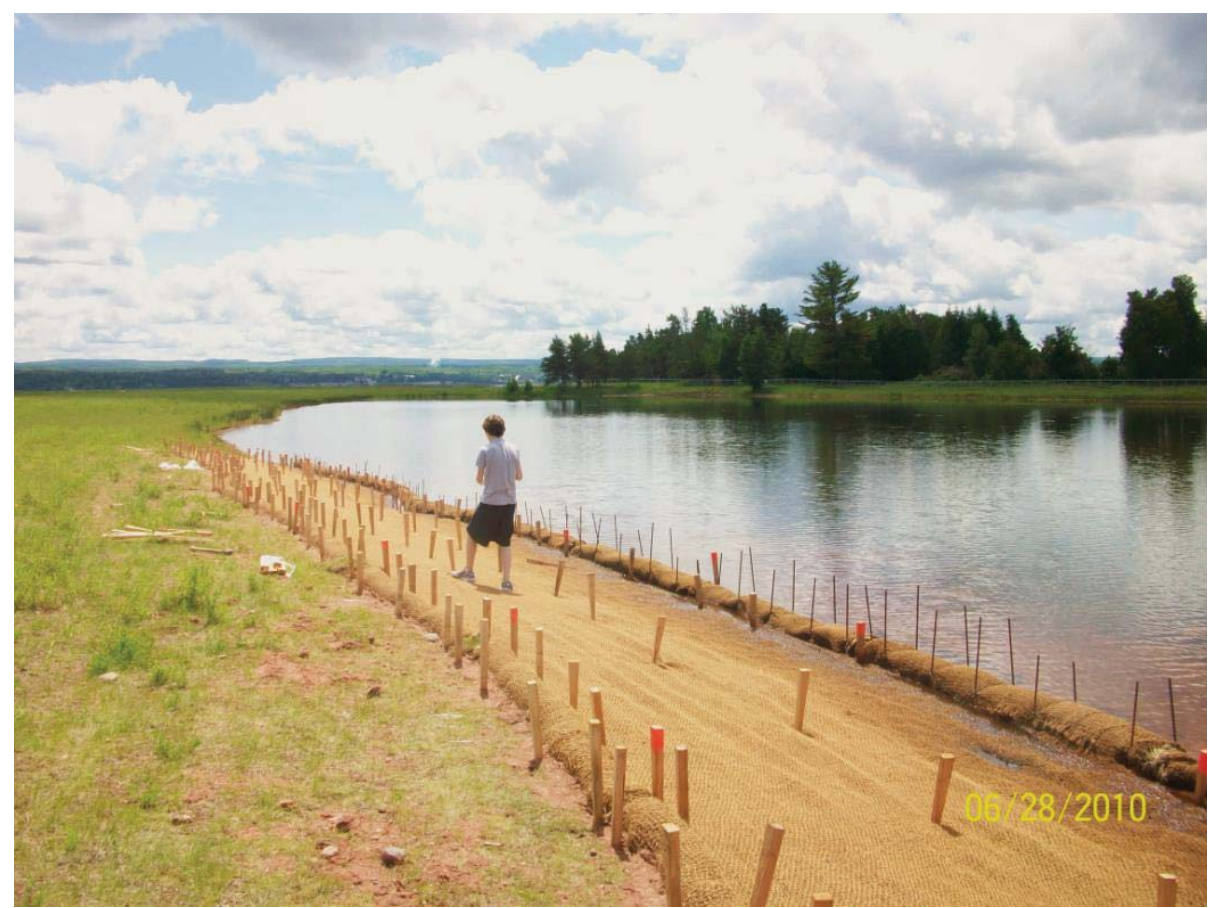

Figure 4.3. The Sand Point restoration site showing completed planting (June 28, 2010). Photograph by J. Bess.

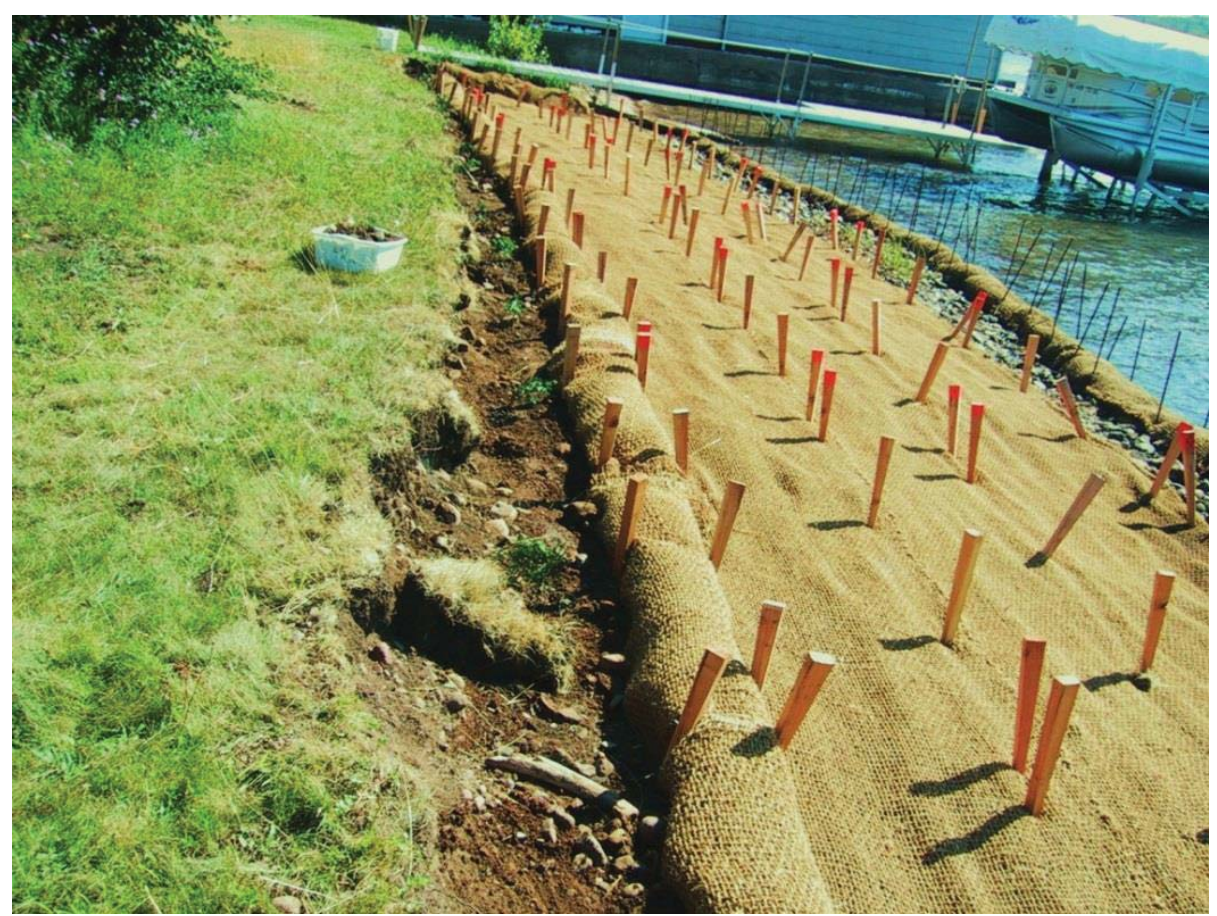

Figure 4.4. The Marsin restoration site showing completed planting (June 26, 2010). Photograph by J. Bess. 


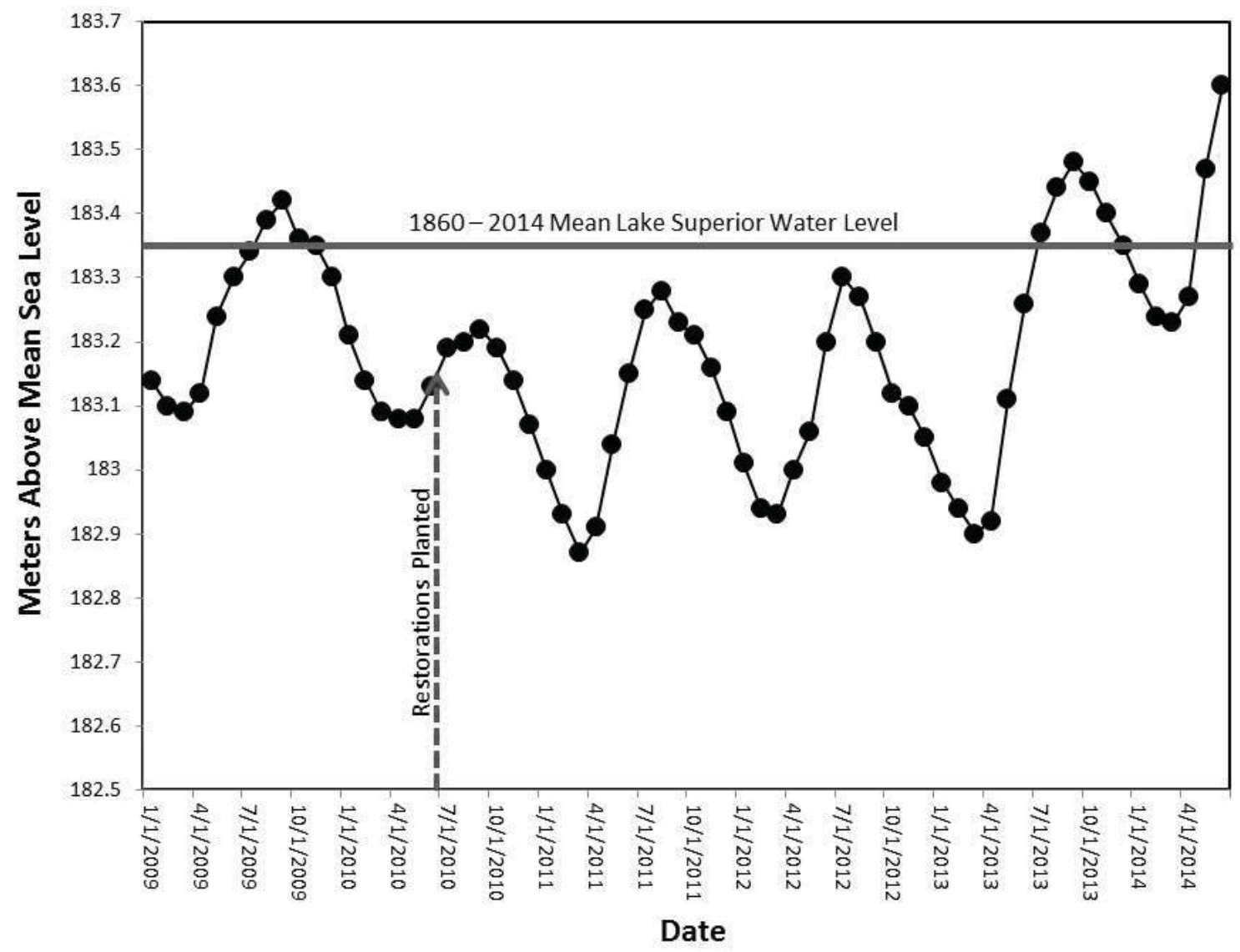

Figure 4.5. Lake Superior water levels 2009 - 2014 with 154 year mean water level and date of restoration plantings at Marsin and Sand Point. Data from NOAA. 

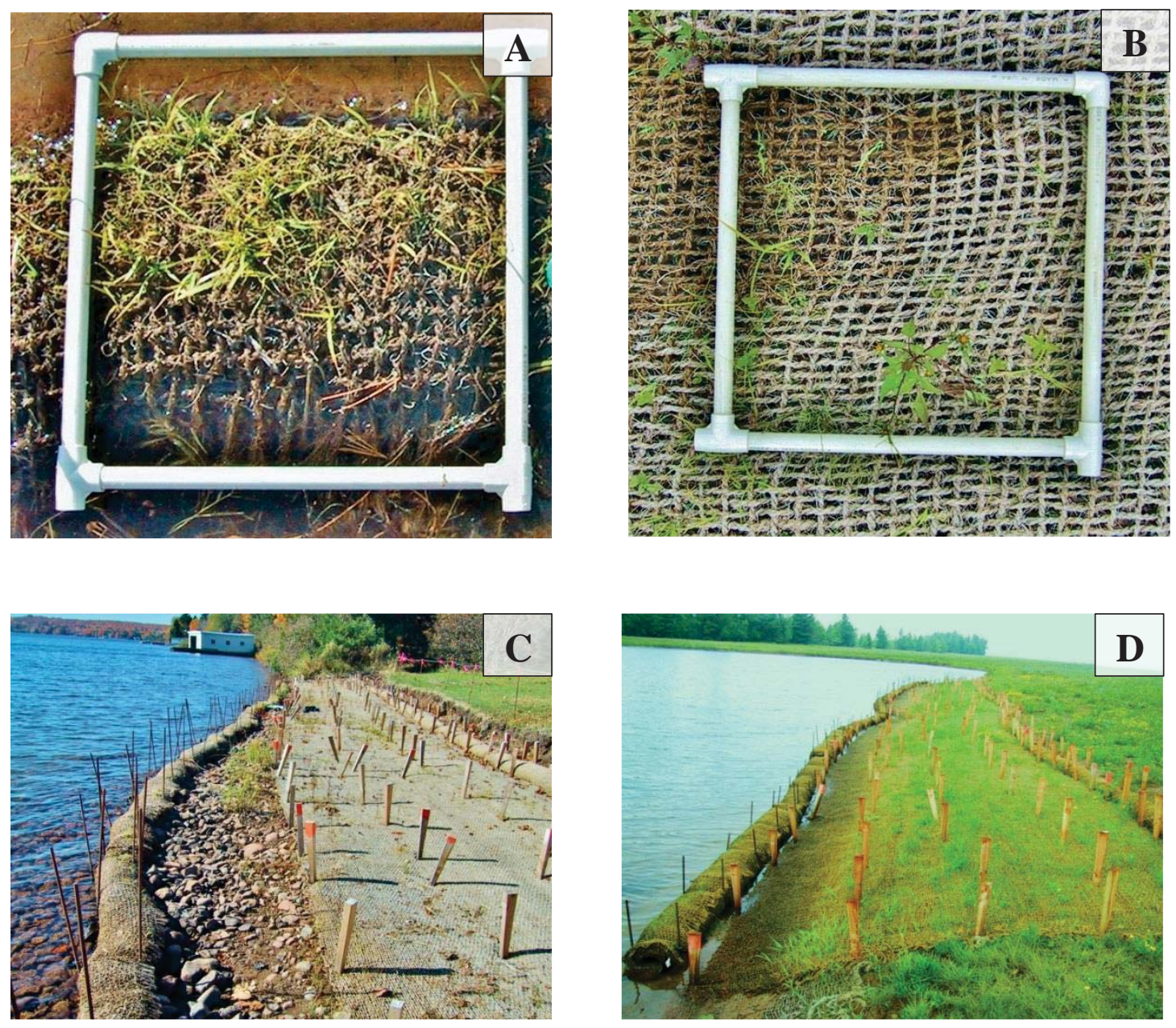

Figure 4.6A-D. Photos showing initial germination of seedlings at the Marsin and Sand Point restoration sites (2010). A.) Marsin Emergent Log - close up, B.) Marsin Fen Meadow - close up, C.) Marsin Center - entire restoration, D.) Sand Point - entire restoration. Photographs by J. Bess. 

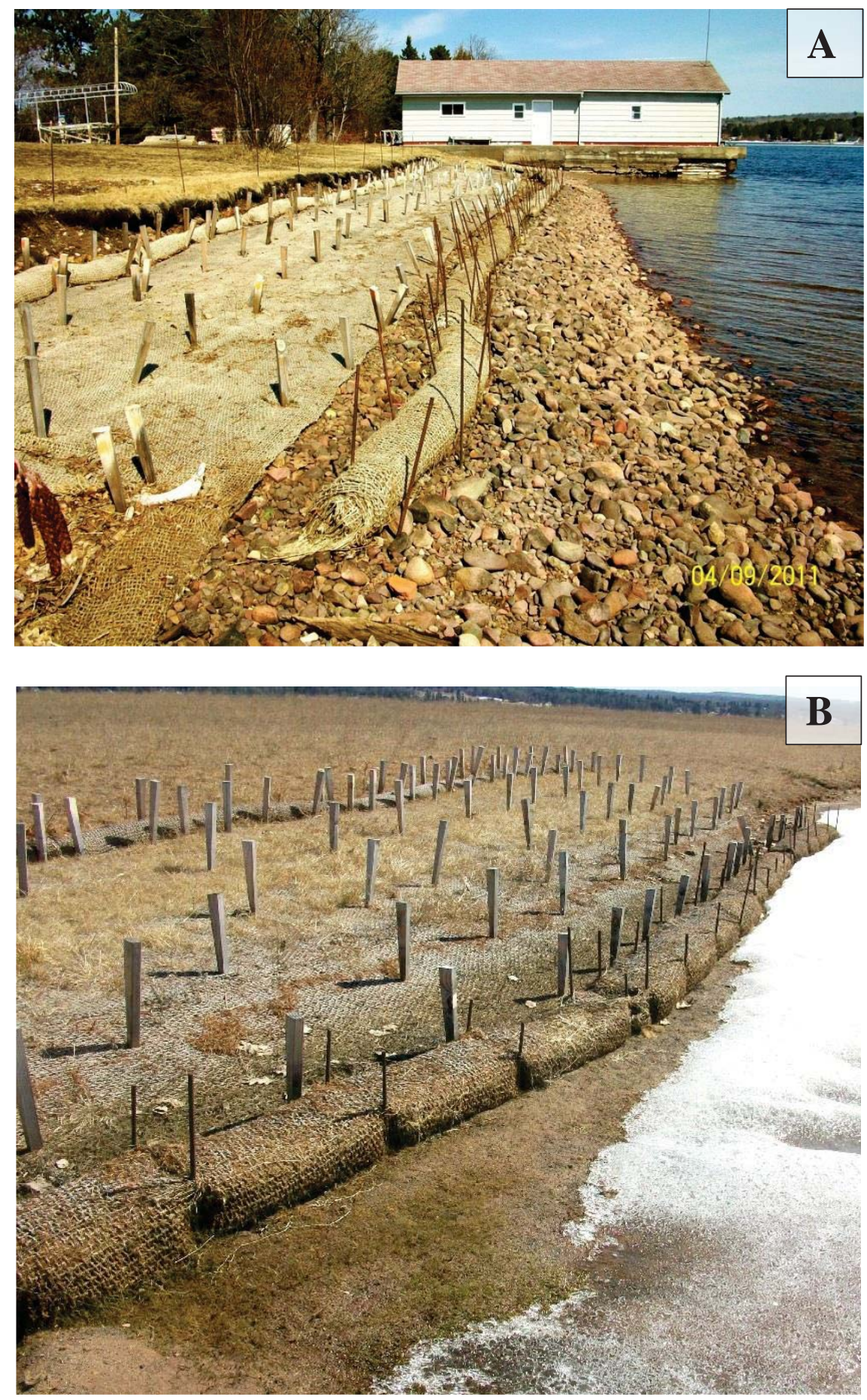

Figure 4.7A-B. The Marsin and Sand Point restoration sites showing low Lake Superior water levels in spring of 2011. A) Marsin wetland restoration site on April 9, 2011; B) Sand Point wetland restoration site on March 17, 2011. Photographs by J. Bess. 

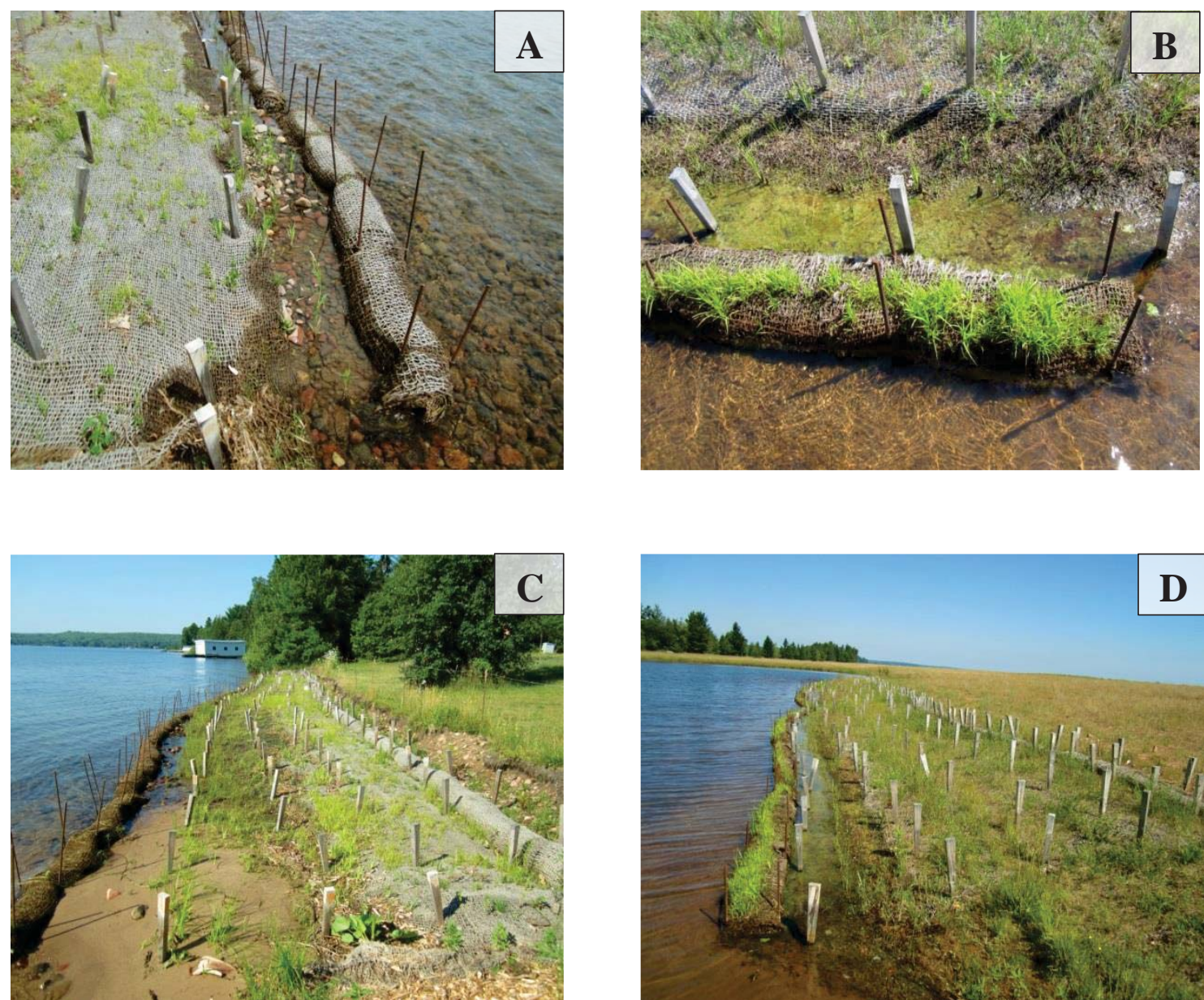

Figure 4.8A-D. Photographs showing condition of vegetation at the Marsin and Sand Point restoration sites in August, 2011. A.) Marsin site showing death of seedlings in emergent zone logs. B.) Sand Point site showing continued growth of seedlings in emergent logs. C.) Marsin site showing growth of wetland vegetation in wet meadow zone. D.) Sand Point site showing growth of vegetation in emergent logs and wet meadow zones.

Photographs by J. Bess. 


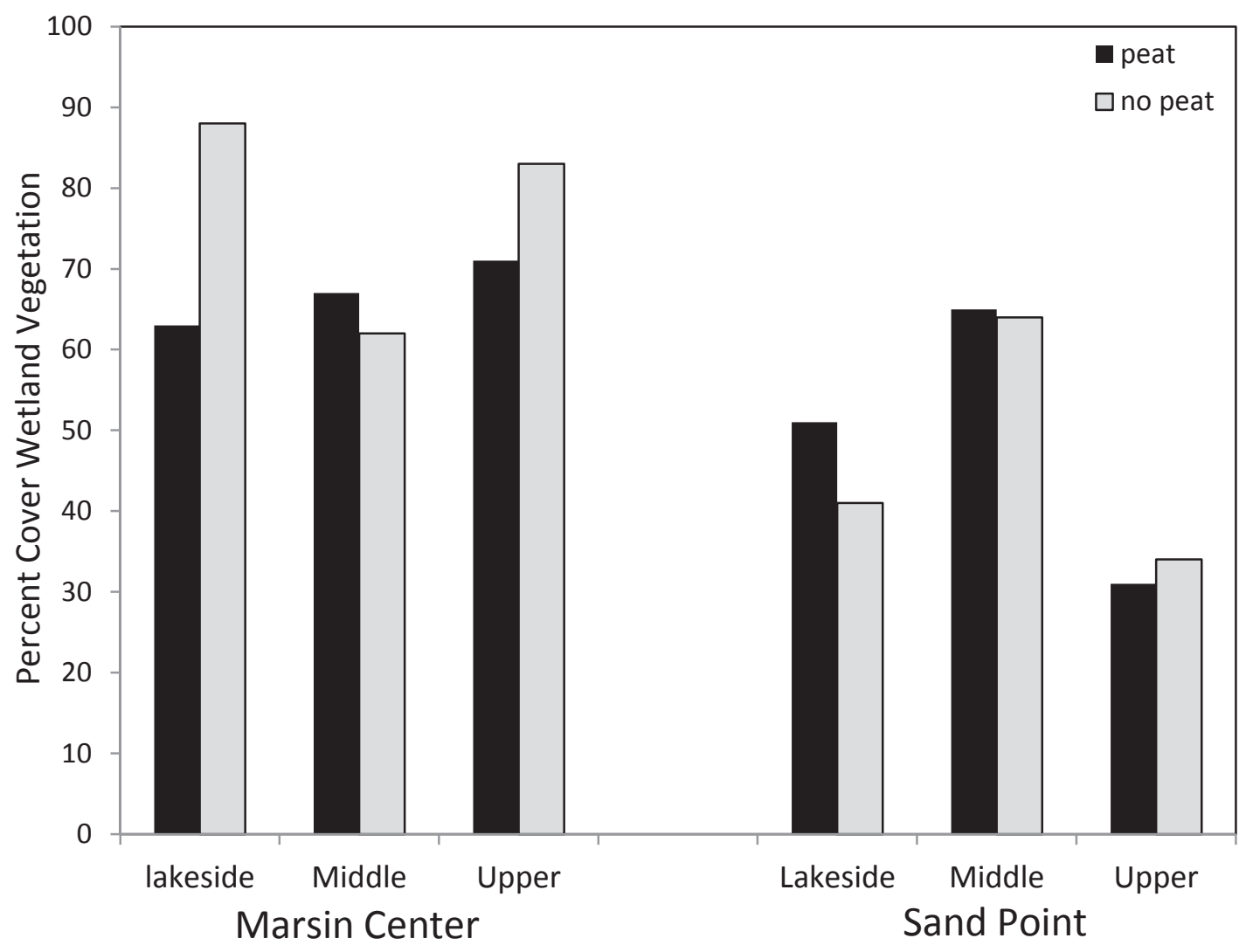

Figure 4.9. Average vegetative cover at the Marsin and Sand Point restoration sites 1 year post-planting (2010). 


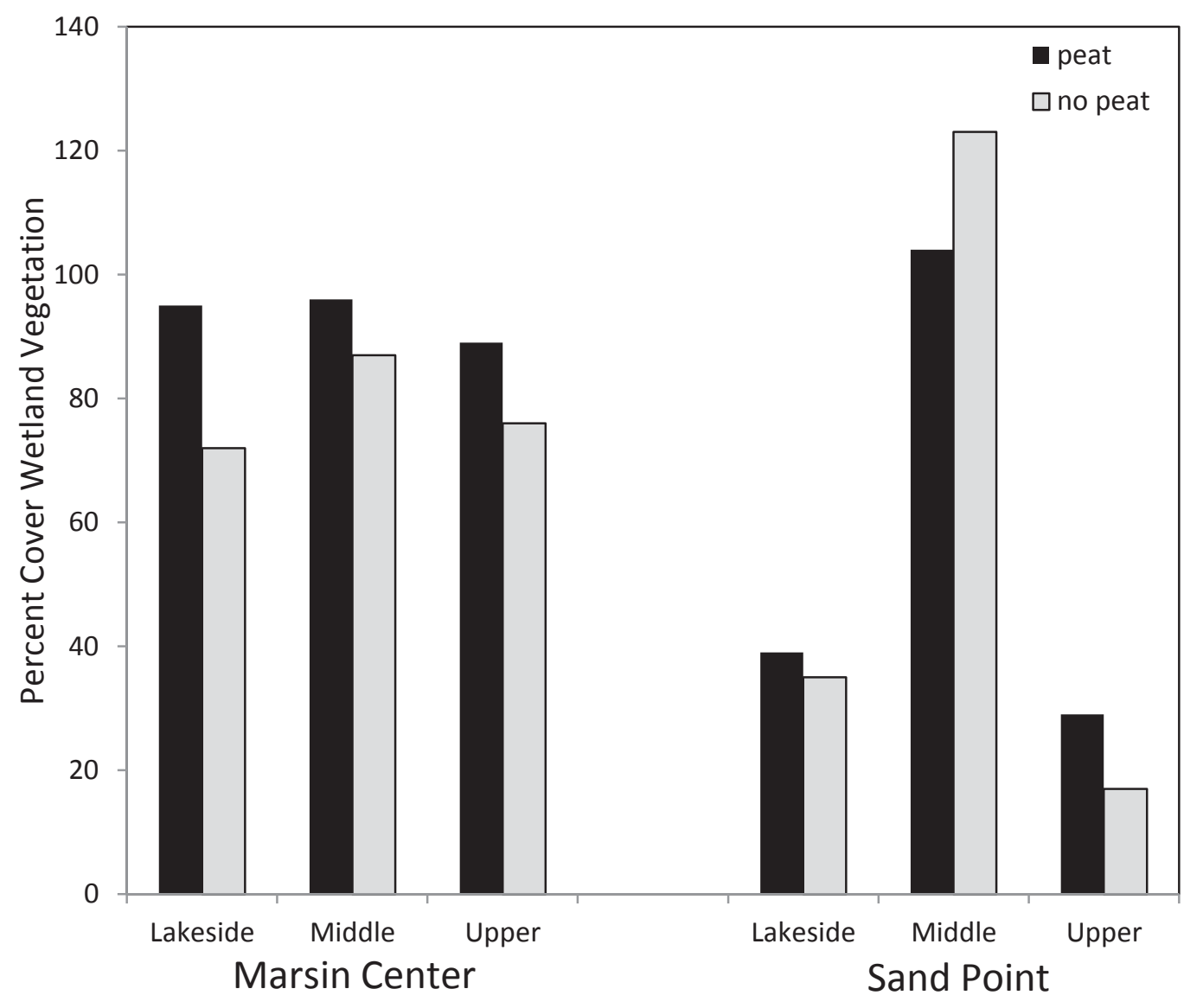

Figure 4.10. Average vegetative cover at the Marsin and Sand Point restoration sites 2 years post-planting (2011). 

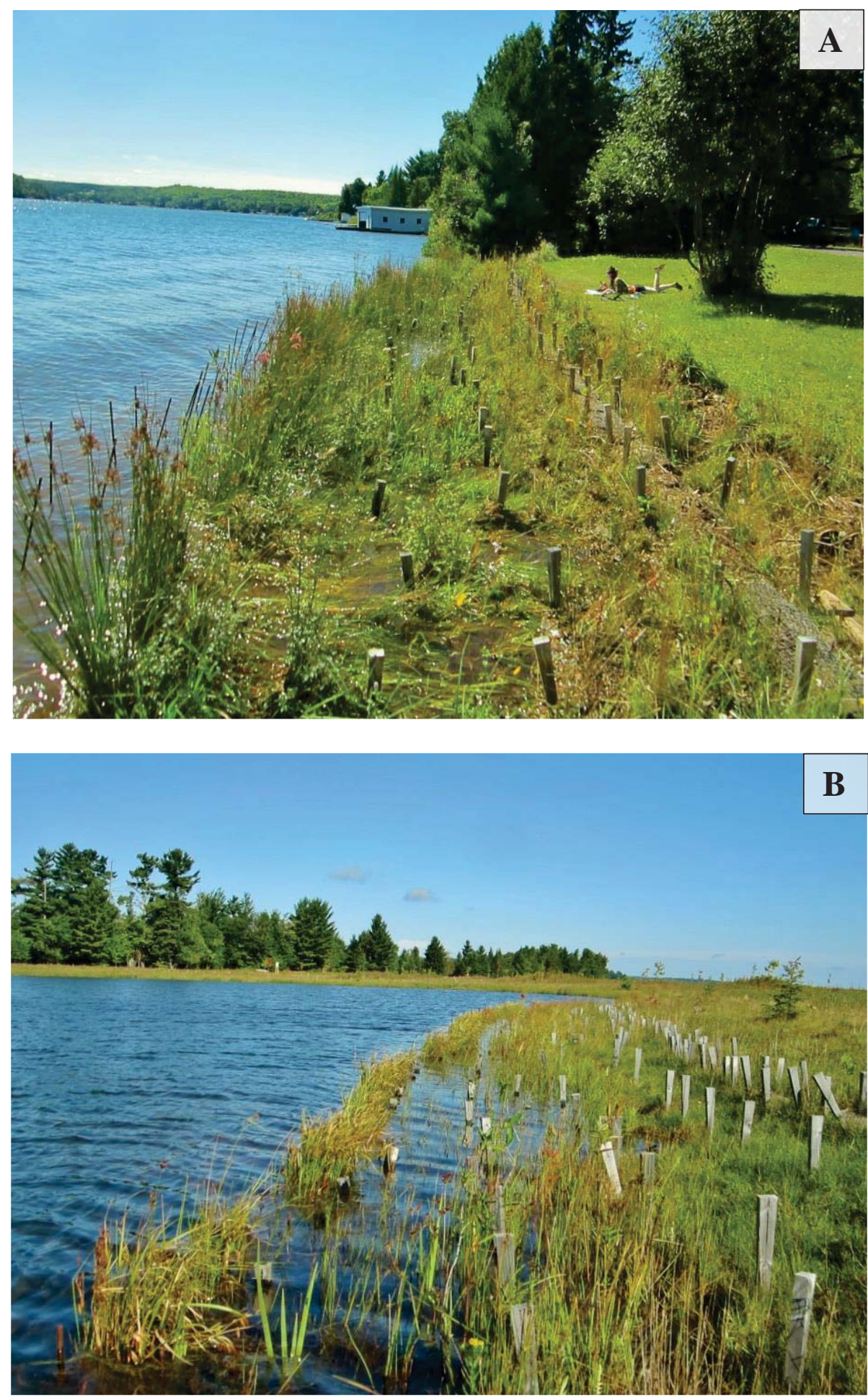

Figure 4.11A-B. Photos showing condition of vegetation and water levels at the Marsin and Sand Point restoration sites 3 years post-planting. A.) Marsin Center and B.) Sand Point in August, 2013. Photographs by J. Bess. 


\section{Marsin}

\section{Sand Point}

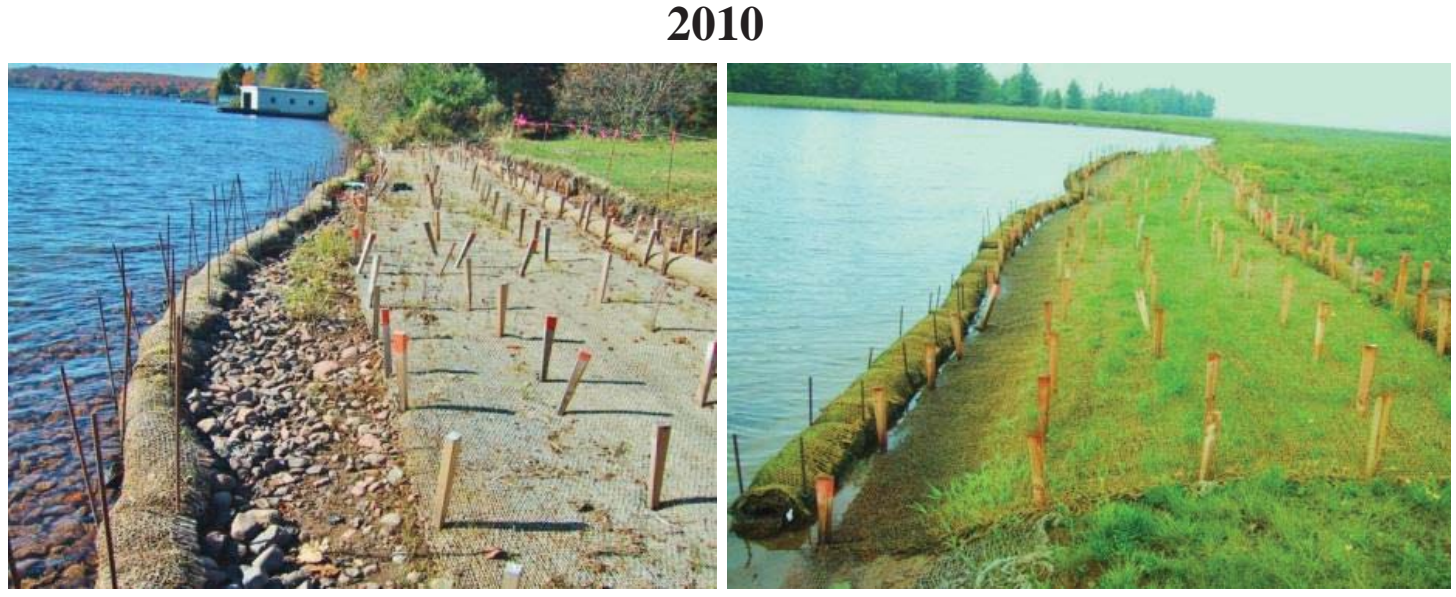

2011

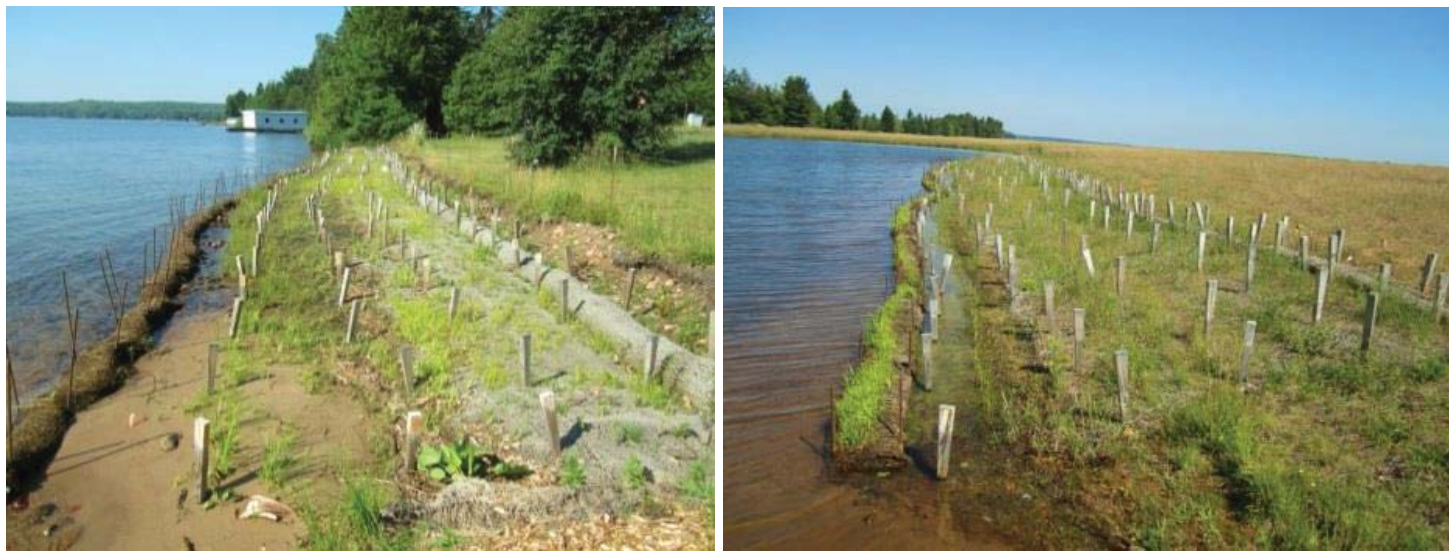

\section{3}
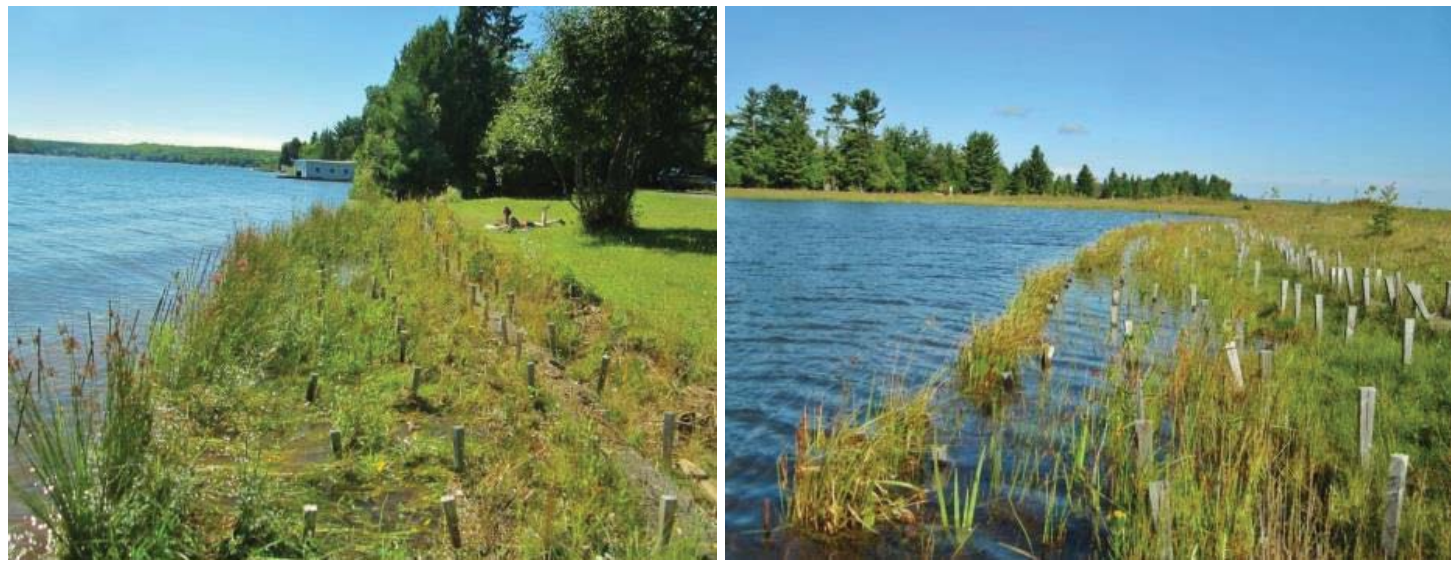

Figure 4.12. Time sequence photographs of Marsin and Sand Point restoration sites showing condition of vegetation and lake water levels (2010-2013). Photographs by J. Bess. 


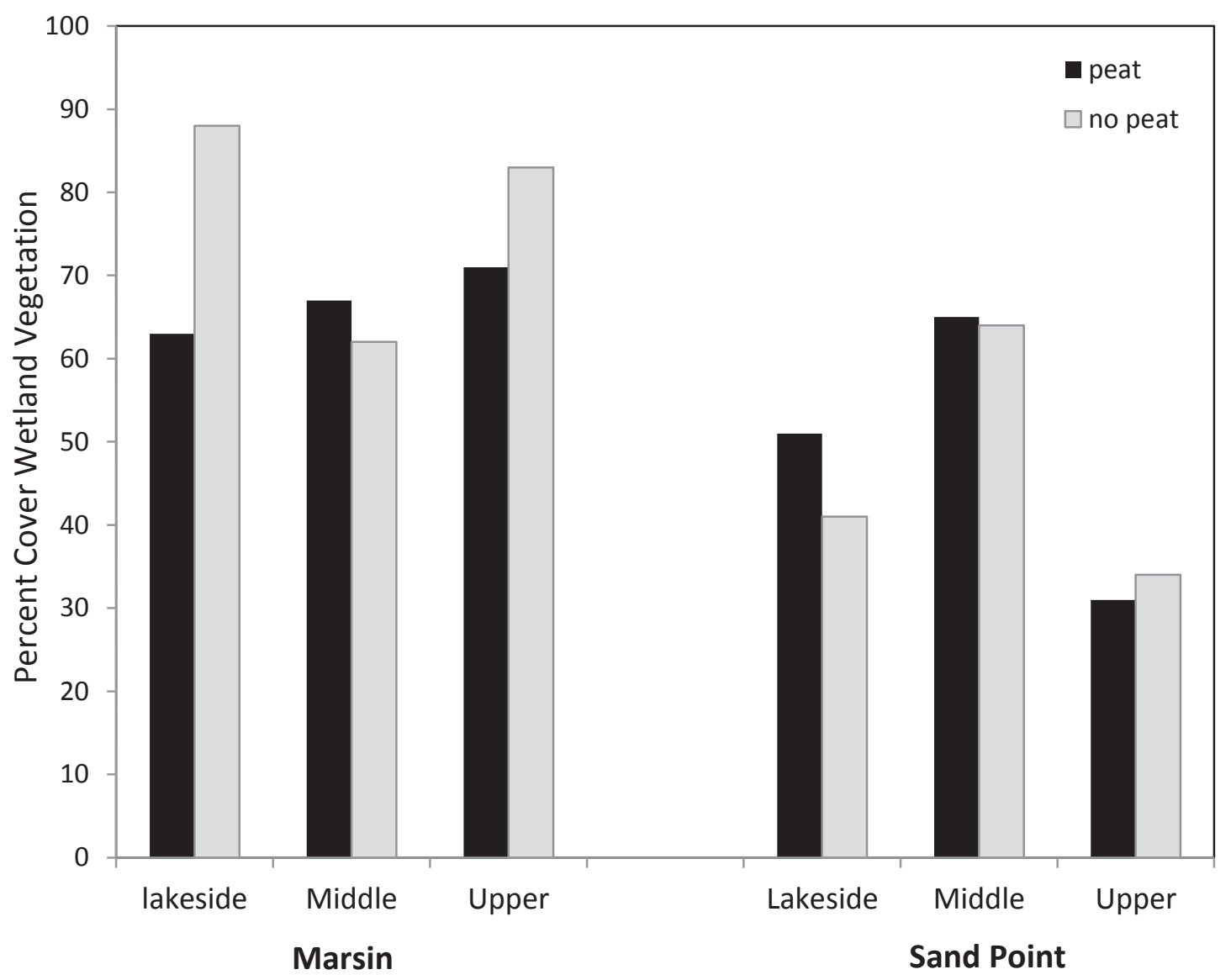

Figure 4.13. Vegetative cover at the Marsin and Sand Point restoration sites in 2013. 


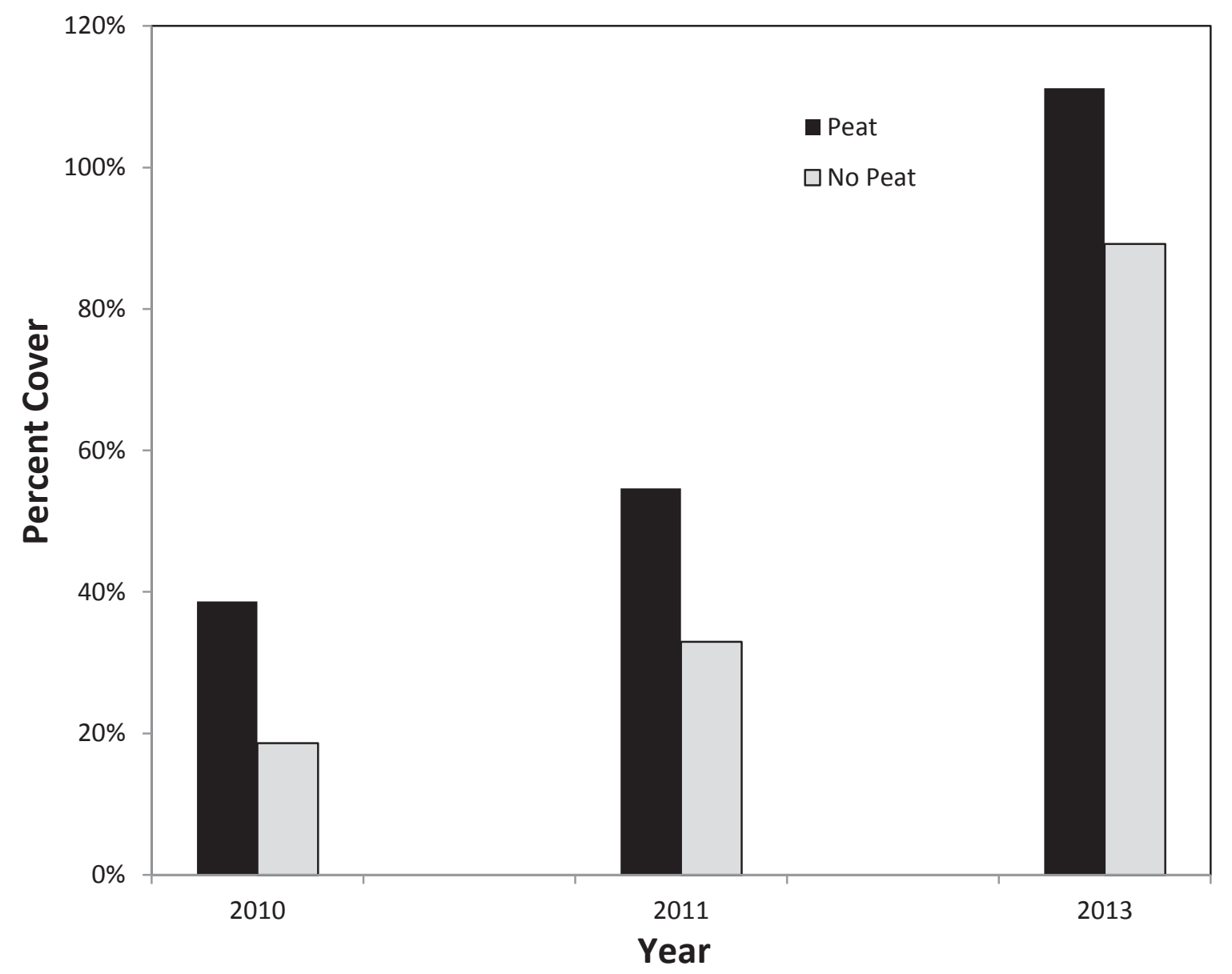

Figure 4.14. Vegetative cover on the emergent logs at the Sand Point restoration site 2010-2013. 


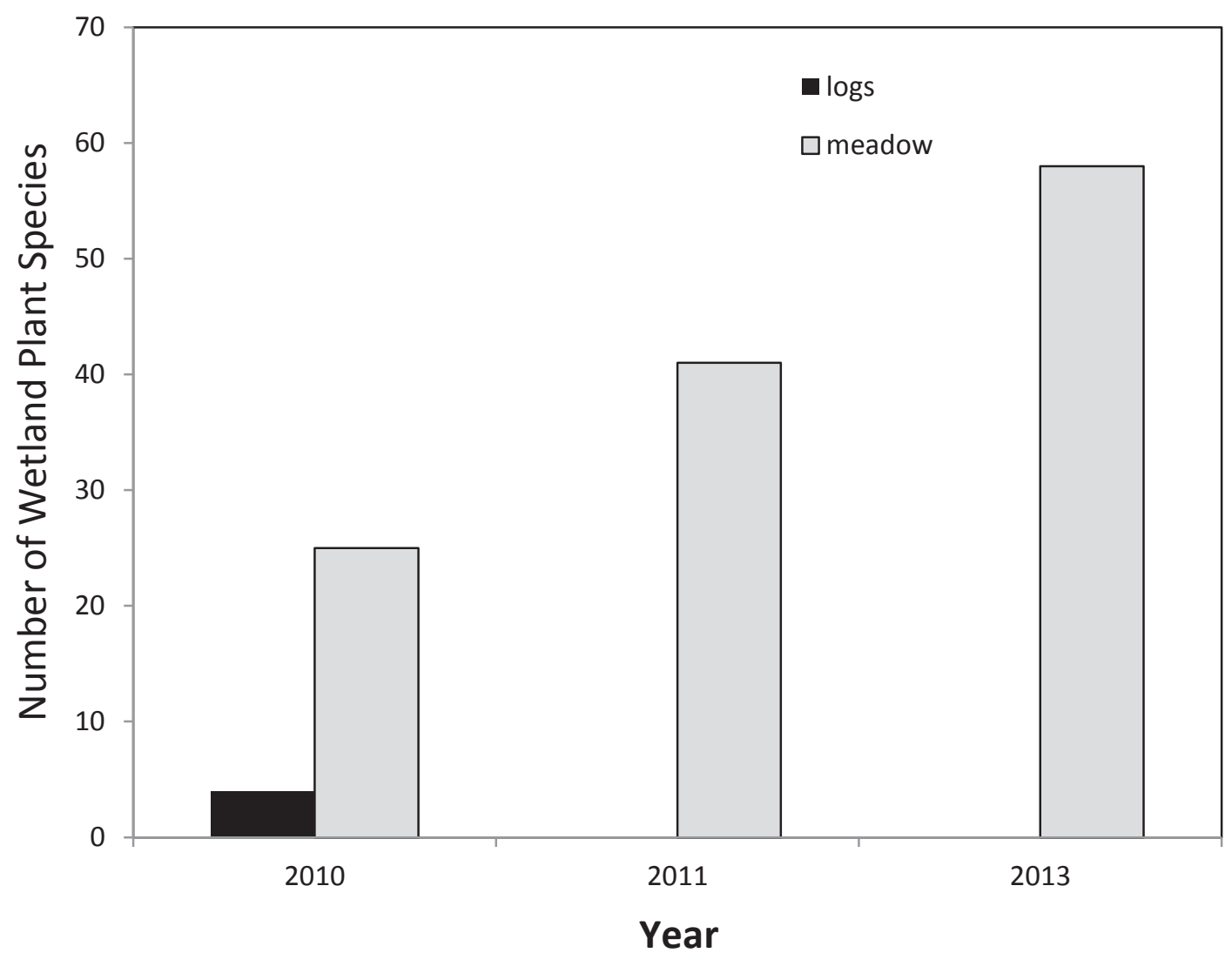

Figure 4.15. Wetland plant species diversity in the emergent logs and fen meadow plots at the Marsin restoration site (2010-2013). 


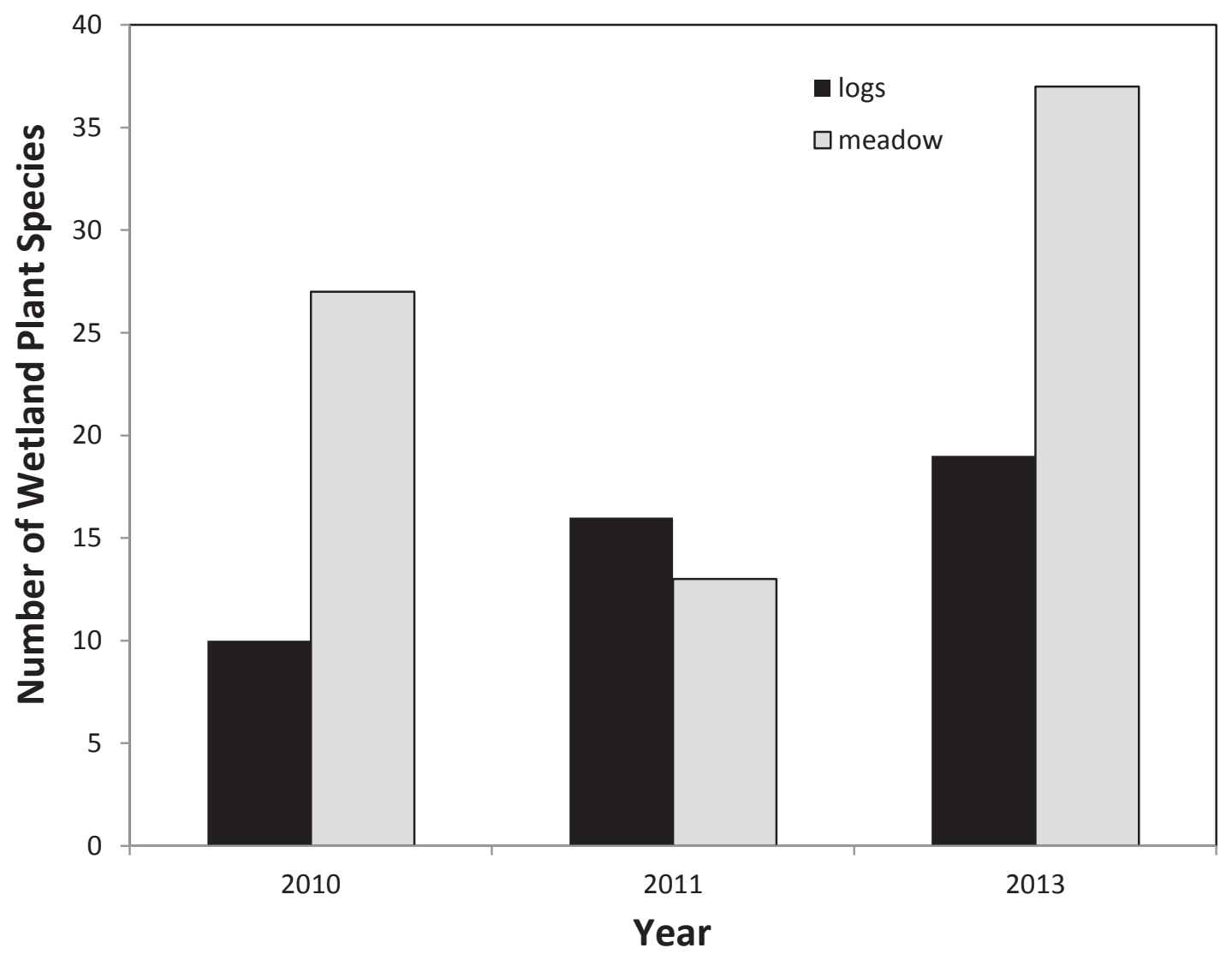

Figure 4.16. 2010-2013 wetland plant species diversity at the Sand Point restoration site. 
Table 4.1. Vegetation cover by plant species at the Marsin Center site prior to clearing for restoration (2009).

Wetland Species

\begin{tabular}{|c|c|c|c|c|c|c|c|c|c|c|c|}
\hline \multirow{2}{*}{$\begin{array}{c}\text { Plant } \\
\text { Species }\end{array}$} & \multicolumn{10}{|c|}{ Plot Number } & \multirow{2}{*}{$\begin{array}{l}\text { Mean } \\
\text { Cover }\end{array}$} \\
\hline & 1 & 2 & 3 & 4 & 5 & 6 & 7 & 8 & 9 & 10 & \\
\hline Agrostis perennans & & & & & & & & & 10 & & 1 \\
\hline Alnus incana & & & & & & & 22 & & & & 2.2 \\
\hline Anemone canadensis & & & & 12 & & 2 & & & 27 & & 4.1 \\
\hline Calamagrostis canadensis & & & 25 & 3 & 80 & & 11 & 20 & 17 & 10 & 17 \\
\hline Carex stricta & 35 & 18 & 65 & 80 & 60 & 20 & 15 & 40 & 35 & 5 & 37 \\
\hline Cornus stolonifera & & & & & & & & & & 25 & 2.5 \\
\hline Doellingeria umbellatus & & & 4 & & & & & & & & 0.4 \\
\hline Eupatorium maculatum & & & & 3 & & & & & & & 0.3 \\
\hline Euthamia graminifolia & & & 2 & & & & & & & & 0.2 \\
\hline Impatiens capensis & & & & & & 1 & & 2 & 1 & & 0.4 \\
\hline Lycopus uniflorus & & & 1 & & 1 & & & & & & 0.2 \\
\hline Mentha x spicata & 40 & 48 & 18 & 15 & 15 & 4 & 5 & 15 & 25 & 5 & 19 \\
\hline Myrica gale & & & 3 & & 25 & 70 & 65 & & & 40 & 20 \\
\hline Phalaris arundinacea & 25 & 60 & 10 & 12 & 3 & 10 & 10 & 70 & 35 & 60 & 29 \\
\hline Physocarpus opulifolius & & & & & & 5 & & & & & 0.5 \\
\hline Salix spp. & 5 & & & 1 & & & & & & & 0.6 \\
\hline Symphyotrichum puniceus & & & 1 & 6 & 3 & & & & & & 1 \\
\hline Symphyotrichum simplex & 3 & & & 2 & 2 & & & 13 & & 8 & 2.8 \\
\hline Totals: & 108 & 126 & 129 & 134 & 189 & 112 & 128 & 160 & 150 & 153 & 139 \\
\hline
\end{tabular}

Upland Species

\begin{tabular}{|c|c|c|c|c|c|c|c|c|c|c|c|}
\hline \multirow{2}{*}{$\begin{array}{c}\text { Plant } \\
\text { Species }\end{array}$} & \multicolumn{10}{|c|}{ Plot Number } & \multirow{2}{*}{$\begin{array}{l}\text { Mean } \\
\text { Cover }\end{array}$} \\
\hline & 1 & 2 & 3 & 4 & 5 & 6 & 7 & 8 & 9 & 10 & \\
\hline Agropyron repens & & & & & & & & & 1 & 2 & 0.3 \\
\hline Dactylis glomerata & & & & 5 & & & & & & & 0.5 \\
\hline Danthonia spicata & 7 & 3 & 8 & 2 & & & & & 6 & & 2.6 \\
\hline Festuca sp. & 2 & & & & & & & & & & 0.2 \\
\hline Fragaria virginica & & & & 1 & & & 1 & & & & 0.2 \\
\hline Gnaphalium obtusifolium & & & & & & & 4 & & & & 0.4 \\
\hline Hieracium sp. & & & & & & & 2 & & & & 0.2 \\
\hline Poa compressa & & & & & & 15 & 15 & & 20 & & 5 \\
\hline Solidago canadensis & 12 & & 2 & & & 3 & & & 1 & 3 & 2.1 \\
\hline Sonchus arvensis & 5 & 5 & 4 & & & & & & & & 1.4 \\
\hline Taraxicum officinale & & & & 1 & & & & & 1 & 1 & 0.3 \\
\hline Totals: & 26 & 8 & 14 & 9 & 0 & 18 & 22 & 0 & 29 & 6 & 13 \\
\hline
\end{tabular}


Table 4.2. Plant species used in the 2010 Marsin and Sand Point restoration plantings and seed amounts per log and plot.

\begin{tabular}{|c|c|c|c|}
\hline \multirow[b]{2}{*}{ Species } & \multicolumn{3}{|c|}{$\begin{array}{c}\text { Seed amounts (grams) per } \\
\text { Log/Plot }\end{array}$} \\
\hline & Emergent & Meadow & Shrub \\
\hline Acorus calamus & 4 & & \\
\hline Aronia melanocarpa & & & 0.5 \\
\hline Asclepias incarnata & 0.5 & 2 & \\
\hline Bidens mix & & 4 & \\
\hline Calamagrostis can. & 0.5 & 2 & \\
\hline Carex comosa & 4 & 4 & \\
\hline Carex crinita & 4 & 5 & \\
\hline Carex magellanica & & 2 & \\
\hline Carex projecta & & 4 & \\
\hline Carex pseudocyperus & 2 & 1 & \\
\hline Carex retrorsa & & 3 & \\
\hline Carex scoparia & & 3 & \\
\hline Carex vesicaria & & 0.8 & \\
\hline Cladium mariscoides & 5 & 5 & \\
\hline Cornus stolonifera & & & 4 \\
\hline Doellingeria umb. & & 4 & \\
\hline Eleocharis palustris & 4 & 4 & \\
\hline Eriocaulon aquaticum & & 0.5 & \\
\hline Eupatorium mac. & & 2 & \\
\hline Eupatorium perf. & & 0.5 & \\
\hline Euthamia gramnifolia & & 2 & \\
\hline Ilex verticillata & & & 1.5 \\
\hline Iris versicolor & 5 & 4 & \\
\hline
\end{tabular}

\begin{tabular}{|c|c|c|c|}
\hline \multirow[b]{2}{*}{ Species } & \multicolumn{3}{|c|}{$\begin{array}{c}\text { Seed amounts (grams) per } \\
\text { Log/Plot }\end{array}$} \\
\hline & Emergent & Meadow & Shrub \\
\hline Juncus balticus & 0.5 & 2 & \\
\hline Juncus effusus & 3 & 2 & \\
\hline Juncus spp. mix & 1.5 & 2 & \\
\hline Larix laricina & & & 0.9 \\
\hline Lycopus mix & & 1 & \\
\hline Myrica gale & & & 4.5 \\
\hline Physocarpus opul. & & & 1.5 \\
\hline Pontederia cordata & 5 & 5 & \\
\hline Rosa palustris & & & 4 \\
\hline Sagittaria latifolia & 1 & 1 & \\
\hline Sambucus canadensis & & & 3 \\
\hline Scirpus acutus & 2 & 2 & \\
\hline Scirpus atrovirens & & 1 & \\
\hline Scirpus cyperinus & 2 & 1 & \\
\hline Solidago uliginosa & & 2 & \\
\hline Sparganium amer. & 5 & 4 & \\
\hline Sparganium eury. & 5 & 4 & \\
\hline Thalictrum dasy. & & 6 & \\
\hline Thuja occidentalis & & & 4 \\
\hline Triadenum fraseri & & 2 & \\
\hline Viburnum cassinoides & & & 2 \\
\hline Viburnum opulus & & & 2 \\
\hline Totals per log/plot: & 54 & 88 & 28 \\
\hline
\end{tabular}


Table 4.3. Average vegetative cover on the emergent log and fen meadow zones at the A) Marsin and B) Sand Point restoration sites in late summer 2010.

A. Marsin

\begin{tabular}{rcccccc}
\hline \multicolumn{7}{c}{ Peat Sectors/Logs } \\
Zone/Sector & $\mathbf{1}$ & $\mathbf{2}$ & $\mathbf{3}$ & $\mathbf{4}$ & $\mathbf{5}$ & Ave. \\
\hline Emergent Logs & 11 & 15 & 17 & 24 & 27 & $\mathbf{1 9}$ \\
Wet Meadow & & & & & & \\
Lakeside & 31 & 46 & 71 & 46 & 41 & $\mathbf{4 7}$ \\
Middle & 37 & 68 & 63 & 61 & 52 & $\mathbf{5 6}$ \\
Upper & 40 & 62 & 68 & 25 & 46 & $\mathbf{4 8}$ \\
Average & $\mathbf{3 6}$ & $\mathbf{5 9}$ & $\mathbf{6 7}$ & $\mathbf{4 4}$ & $\mathbf{4 6}$ & $\mathbf{5 0}$ \\
\hline
\end{tabular}

\section{B. Sand Point}

\begin{tabular}{|c|c|c|c|c|c|c|c|c|c|c|c|c|}
\hline \multirow[b]{2}{*}{ Zone/Sector } & \multicolumn{6}{|c|}{ Peat Sectors/Logs } & \multicolumn{6}{|c|}{ No Peat Sectors/Logs } \\
\hline & 1 & 2 & 3 & 4 & 5 & Ave. & 1 & 2 & 3 & 4 & 5 & Ave. \\
\hline Emergent Logs & 38 & 35 & 41 & 32 & 47 & 39 & 21 & 28 & 12 & 15 & 16 & 18 \\
\hline \multicolumn{13}{|l|}{ Wet Meadow } \\
\hline Lakeside & 22 & 123 & 137 & 142 & 126 & 110 & 43 & 130 & 108 & 106 & 73 & 92 \\
\hline Middle & 134 & 124 & 166 & 170 & 115 & 142 & 105 & 110 & 157 & 160 & 122 & 131 \\
\hline Upper & 32 & 1 & 12 & 11 & 35 & 18 & 6 & 7 & 5 & 12 & 53 & 17 \\
\hline Average & 63 & 83 & 105 & 108 & 92 & 90 & 51 & 82 & 90 & 93 & 83 & 80 \\
\hline
\end{tabular}

\begin{tabular}{cccccc}
\hline \multicolumn{6}{c}{ No Peat Sectors/Logs } \\
$\mathbf{1}$ & $\mathbf{2}$ & $\mathbf{3}$ & $\mathbf{4}$ & $\mathbf{5}$ & Ave. \\
\hline 12 & 9 & 38 & 33 & 39 & $\mathbf{2 6}$ \\
& & & & & \\
29 & 30 & 27 & 16 & 24 & $\mathbf{2 5}$ \\
18 & 37 & 54 & 38 & 51 & $\mathbf{4 0}$ \\
25 & 41 & 31 & 37 & 49 & $\mathbf{3 7}$ \\
$\mathbf{2 4}$ & $\mathbf{3 6}$ & $\mathbf{3 7}$ & $\mathbf{3 0}$ & $\mathbf{4 1}$ & $\mathbf{3 4}$ \\
\hline
\end{tabular}


Table 4.4. Percent cover for select wetland plant species in the emergent log and fen meadow zones at the Marsin and Sand Point restoration sites in late summer $2010 .^{1}$

\begin{tabular}{ccccccccccc}
\hline & \multicolumn{1}{c}{ Marsin 2010} \\
& Emergent & \multicolumn{1}{c}{ Fen Meadow Sectors } & \multicolumn{1}{c}{ Meadow } \\
Logs & Lakeside & Middle & Upper & Totals \\
Plant Species & P & N & P & N & P & N & P & N & P & N \\
\hline
\end{tabular}

Agrostis hyemale

Asclepias incarnata $1 \% \quad 1 \% \quad 1 \% \quad 1 \% \quad 1 \% \quad 1 \%$

Aster umbellatus

Bidens frondoso

Carex spp. $4 \% \quad 4 \% \quad 20 \% \quad 9 \% \quad 19 \% \quad 16 \% \quad 22 \% \quad 17 \% \quad 20 \% 14 \%$

Echinocloa crus-galli

Eleocharis acicularis

Eleocharis palustris

Epilobium sp.

forb seedlings $1 \% \quad \begin{array}{llllllll}4 \% & 3 \% & 4 \% & 5 \% & 3 \% & 3 \% & 4 \% & 4 \%\end{array}$

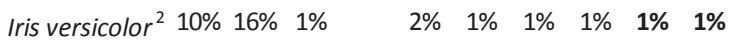

Juncus arcticus

Juncus effusus

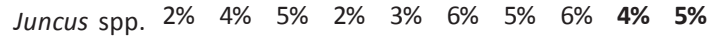

$\begin{array}{lllllll}\text { Lycopus spp. } & 1 \% & 1 \% & 1 \% & \mathbf{1} \% & \mathbf{0} \%\end{array}$

Persicaria pensylvanica

Phalaris arundinacea

Pontederia cordata

Sagittaria latifolia

Scirpus spp.

Thalictrum dasycarpum

Total Cover $18 \%$ 25\% 45\% 22\% 41\% 38\% 39\% 35\% 41\% 32\%

\begin{tabular}{cccccccccc}
\hline \multicolumn{1}{c}{ Sand Point 2010} \\
Emergent & \multicolumn{4}{c}{ Fen Meadow Sectors } & \multicolumn{1}{c}{ Meadow } \\
Logs & Lakeside & Middle & Upper & \multicolumn{2}{c}{ Totals } \\
P & $\mathbf{N}$ & $\mathbf{P}$ & $\mathbf{N}$ & $\mathbf{P}$ & $\mathbf{N}$ & $\mathbf{P}$ & $\mathbf{N}$ & $\mathbf{P}$ & $\mathbf{N}$ \\
\hline
\end{tabular}

$0 \% \quad 4 \% \quad 3 \% \quad 2 \%$

$\begin{array}{lllllllll}0 \% & 1 \% & 1 \% & 1 \% & 0 \% & & 0 \% & 1 \%\end{array}$

$2 \% \quad 6 \% \quad 4 \% \quad 2 \% \quad 2 \% \quad 3 \%$

$\begin{array}{llllllllll}12 \% & 5 \% & 20 \% & 29 \% & 4 \% & 6 \% & 6 \% & 3 \% & 10 \% & 13 \%\end{array}$

$\begin{array}{lllllll}1 \% & 11 \% & 10 \% & 1 \% & 4 \% & 3 \%\end{array}$

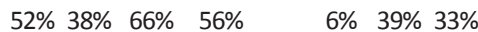

$1 \% \quad 2 \%$

$\begin{array}{lllll}2 \% & 2 \% & 1 \% & 1 \%\end{array}$

$\begin{array}{llllllll}1 \% & 1 \% & 1 \% & 3 \% & 2 \% & & 1 \% & 1 \%\end{array}$

$11 \% 8 \%$

\begin{tabular}{|c|c|c|c|c|c|c|c|c|c|}
\hline & & $1 \%$ & & $11 \%$ & $10 \%$ & $3 \%$ & & $5 \%$ & $3 \%$ \\
\hline & & & & & $4 \%$ & & $1 \%$ & & $\%$ \\
\hline $6 \%$ & $1 \%$ & $9 \%$ & $7 \%$ & $7 \%$ & $10 \%$ & & $3 \%$ & $6 \%$ & $7 \%$ \\
\hline & & & & $2 \%$ & $2 \%$ & & & $1 \%$ & $1 \%$ \\
\hline & & $1 \%$ & $1 \%$ & $1 \%$ & $2 \%$ & & & $1 \%$ & \\
\hline
\end{tabular}

$1 \%$

$\begin{array}{lllll}2 \% & 1 \% & 5 \% & 1 \% & 2 \%\end{array}$

$5 \% \quad 1 \%$

$38 \%$ 18\% 93\% 84\% $115 \%$ 108\% $15 \%$ 13\% $77 \%$ 69\%

1: Only wetland plant species with $1 \%$ total cover or greater are included. For species with $0.5-0.99 \%$ cover per zone, value was rounded up to $1 \%$. $\mathrm{P}=$ peat plots/logs and $\mathrm{N}=$ no peat plots/logs.

2: The "Iris" seedling values for the emergent logs likely include some Sparganium seedlings as these were very difficult to tell apart in the field. 
Table 4.5. Total plant species richness in the emergent log and fen meadow zones at the Marsin and Sand Point restoration sites in late summer 2010. ${ }^{1}$

\begin{tabular}{|c|c|c|c|c|c|c|c|c|c|c|c|c|c|c|c|c|c|c|c|c|}
\hline \multirow[b]{4}{*}{ Plant Species } & \multicolumn{10}{|c|}{ Marsin 2010} & \multicolumn{10}{|c|}{ Sand Point 2010} \\
\hline & \multirow{2}{*}{\multicolumn{2}{|c|}{$\begin{array}{c}\text { Emergent } \\
\text { Logs }\end{array}$}} & \multicolumn{6}{|c|}{ Fen Meadow Sectors } & \multirow{2}{*}{\multicolumn{2}{|c|}{$\begin{array}{c}\text { Meadow } \\
\text { Totals }\end{array}$}} & \multirow{2}{*}{\multicolumn{2}{|c|}{$\begin{array}{c}\text { Emergent } \\
\text { Logs }\end{array}$}} & \multicolumn{6}{|c|}{ Fen Meadow Sectors } & \multirow{2}{*}{\multicolumn{2}{|c|}{$\begin{array}{c}\text { Meadow } \\
\text { Totals }\end{array}$}} \\
\hline & & & Lake & side & Mic & dle & Up & & & & & & Lake & side & & Idle & & & & \\
\hline & $\mathbf{P}$ & $\mathbf{N}$ & $\mathbf{P}$ & $\mathbf{N}$ & $\mathbf{P}$ & $\mathbf{N}$ & $\mathbf{P}$ & $\mathbf{N}$ & $\mathbf{P}$ & $\mathbf{N}$ & $\mathbf{P}$ & $\mathbf{N}$ & $\mathbf{P}$ & $\mathbf{N}$ & $\mathbf{P}$ & $\mathbf{N}$ & $\mathbf{P}$ & $\mathbf{N}$ & $\mathbf{P}$ & $\mathbf{N}$ \\
\hline Agrostis hyemale & & & & & & & & & & & & & & & 1 & & & & 1 & \\
\hline Anemone canadensis & & & & & & & & 1 & & 1 & & & & & & & & & & \\
\hline Aronia melanocarpa & & & & & & & & 1 & & 1 & & & & & & & & & & \\
\hline Asclepias incarnata & 1 & 1 & 1 & 1 & 1 & 1 & 1 & 1 & 1 & 1 & 1 & & 1 & 1 & 1 & 1 & 1 & & 1 & 1 \\
\hline Bidens cernuus & & & 1 & 1 & 1 & 1 & 1 & & 1 & 1 & & & & & 1 & & 1 & & 1 & \\
\hline Bidens frondosa & & & 1 & 1 & 1 & 1 & 1 & 1 & 1 & 1 & 1 & 1 & 1 & 1 & 1 & 1 & & & 1 & 1 \\
\hline Calamagrostis canadensis & & & 1 & 1 & 1 & 1 & 1 & 1 & 1 & 1 & & & & & & & & & & \\
\hline Carex lasiocarpa & 1 & 1 & 1 & 1 & & & & & 1 & 1 & & & & & & & & & & \\
\hline Carex stricta & & & 1 & 1 & & & & & 1 & 1 & & & & & & & & & & \\
\hline Carex spp. & 1 & 1 & 1 & 1 & & 1 & 1 & 1 & 1 & 1 & 1 & 1 & 1 & 1 & 1 & 1 & 1 & 1 & 1 & 1 \\
\hline Doellingeria umbellata & & & 1 & 1 & & 1 & & 1 & 1 & 1 & & & 1 & 1 & 1 & 1 & 1 & & 1 & 1 \\
\hline Echinocloa crus-galli & & & & & & & & & & & & & 1 & 1 & 1 & 1 & 1 & 1 & 1 & 1 \\
\hline Eleocharis acicularis & & & & & & & & & & & & & 1 & 1 & 1 & 1 & & 1 & 1 & 1 \\
\hline Eleocharis palustris & & & & & & 1 & & 1 & & 1 & 1 & 1 & 1 & 1 & & & & & 1 & 1 \\
\hline Epilobium sp. & & & & & & & & & & & & & & 1 & 1 & 1 & & 1 & 1 & 1 \\
\hline Equisetum sp. & & & 1 & & 1 & 1 & & & 1 & 1 & & & & & & & & & & \\
\hline Eupatorium perfoliatum & & & & & & & & & & & & & & & & 1 & & & & 1 \\
\hline Euthamia graminifolia & & & & & & & & 1 & & 1 & & & & & & 1 & & & & 1 \\
\hline forb seedlings & 1 & 1 & 1 & 1 & 1 & 1 & 1 & 1 & 1 & 1 & 1 & 1 & 1 & 1 & 1 & 1 & 1 & & 1 & 1 \\
\hline Iris versicolor $^{2}$ & 1 & 1 & 1 & 1 & 1 & 1 & 1 & 1 & 1 & 1 & 1 & 1 & 1 & 1 & 1 & 1 & & & 1 & 1 \\
\hline Juncus arcticus & & & & & & & & & & & & & 1 & & 1 & 1 & 1 & & 1 & 1 \\
\hline Juncus effusus & & & & & & & & & & & & & & & 1 & 1 & & 1 & 1 & 1 \\
\hline Juncus spp. & 1 & 1 & 1 & 1 & 1 & 1 & 1 & 1 & 1 & 1 & 1 & 1 & 1 & 1 & 1 & 1 & 1 & 1 & 1 & 1 \\
\hline Lycopus spp. & & & 1 & 1 & 1 & 1 & 1 & 1 & 1 & 1 & & & 1 & 1 & 1 & 1 & & & 1 & 1 \\
\hline Mentha $\times$ spicata & & & & & 1 & 1 & & & 1 & 1 & & & & & & & & & & \\
\hline Persicaria pensy/vanica & & & 1 & & 1 & & & & 1 & & & & 1 & 1 & 1 & 1 & & & 1 & 1 \\
\hline Phalaris arundinacea & & & 1 & 1 & 1 & 1 & 1 & 1 & 1 & 1 & & & & & & & & & & \\
\hline Physocarpus opulifolius & & & & & 1 & & & & 1 & & & & & & & & & & & \\
\hline Pontederia cordata & & & & & & & & & & & 1 & 1 & & & & & & & 1 & 1 \\
\hline Potentilla norvegica & & & & & & & & & & & & & & & 1 & 1 & & & 1 & 1 \\
\hline Rumex sp. & & & 1 & & & & & & 1 & & & & & & & & & & & \\
\hline Sagittaria latifolia & & & & & & & & & & & 1 & 1 & 1 & 1 & & & & & 1 & 1 \\
\hline Scirpus spp. & & & 1 & 1 & 1 & 1 & 1 & 1 & 1 & 1 & 1 & 1 & & & & & & & 1 & 1 \\
\hline Shrub seedlings & & & & & & & & & & & & & & 1 & 1 & & & & 1 & 1 \\
\hline Solidago uliginosa & & & & & & & & & & & & & & & 1 & 1 & & & 1 & 1 \\
\hline Spirea alba & & & & & & & & & & & & & & 1 & 1 & 1 & & & 1 & 1 \\
\hline Symphyotrichum simplex & & & & & & & & & & & & & & & & 1 & & & & \\
\hline Thalictrum dasycarpum & & & 1 & 1 & 1 & 1 & 1 & 1 & 1 & 1 & & & 1 & & 1 & 1 & & & 1 & 1 \\
\hline Viola blanda & & & & & & & & & & & & & & & 1 & & & & 1 & \\
\hline Total Species & 6 & 6 & 18 & 15 & 15 & 16 & 12 & 16 & 20 & 21 & 10 & 9 & 15 & 16 & 22 & 21 & 0 & 6 & 26 & 25 \\
\hline
\end{tabular}

$1: \mathrm{P}=$ peat plots/logs and $\mathrm{N}=$ no peat plots/logs. In columns, 1 = present, blank = absent.

2: The "Iris" seedling values for the emergent logs likely include some Sparganium seedlings as these were very difficult to tell apart in the field. 
Table 4.6. Vegetative cover on the emergent logs and in the emergent log and fen meadow zones at the A) Marsin and B) Sand Point restoration in late summer 2011. Peat plots/logs refers to the 5 replicates of each $\log /$ plot per treatment (peat or no peat).

\section{A. Marsin}

\begin{tabular}{|c|c|c|c|c|c|c|c|c|c|c|c|c|}
\hline \multirow[b]{2}{*}{ Zone/Sector } & \multicolumn{6}{|c|}{ Peat Plots/Logs } & \multicolumn{6}{|c|}{ No Peat Plots/Logs } \\
\hline & 1 & 2 & 3 & 4 & 5 & Ave. & 1 & 2 & 3 & 4 & 5 & Ave. \\
\hline Emergent Logs & 0 & 0 & 0 & 0 & 0 & 0 & 0 & 0 & 0 & 0 & 0 & 0 \\
\hline \multicolumn{13}{|l|}{ Fen Meadow } \\
\hline Lakeside & 42 & 85 & 104 & 128 & 116 & 95 & 39 & 79 & 64 & 95 & 83 & 72 \\
\hline Middle & 48 & 80 & 135 & 116 & 130 & 102 & 48 & 91 & 88 & 86 & 121 & 87 \\
\hline Upper & 33 & 76 & 104 & 103 & 101 & 83 & 44 & 87 & 84 & 70 & 96 & 76 \\
\hline Average & 41 & 80 & 114 & 116 & 116 & 93 & 44 & 86 & 79 & 84 & 100 & 78 \\
\hline
\end{tabular}

\section{B. Sand Point}

\begin{tabular}{|c|c|c|c|c|c|c|c|c|c|c|c|c|}
\hline \multirow[b]{2}{*}{ Zone/Sector } & \multicolumn{6}{|c|}{ Peat Plots/Logs } & \multicolumn{6}{|c|}{ No Peat Plots/Logs } \\
\hline & 1 & 2 & 3 & 4 & 5 & Ave. & 1 & 2 & 3 & 4 & 5 & Ave. \\
\hline Emergent Logs & 62 & 48 & 53 & 48 & 62 & 55 & 47 & 21 & 25 & 35 & 37 & 33 \\
\hline \multicolumn{13}{|l|}{ Fen Meadow } \\
\hline Lakeside & 28 & 30 & 40 & 39 & 57 & 39 & 54 & 42 & 24 & 20 & 35 & 35 \\
\hline Middle & 42 & 107 & 124 & 144 & 100 & 103 & 78 & 120 & 138 & 144 & 134 & 123 \\
\hline Upper ${ }^{1}$ & $*$ & $*$ & $*$ & $*$ & $*$ & $*$ & $*$ & $*$ & $*$ & $*$ & $*$ & $*$ \\
\hline Average & 35 & 69 & 82 & 92 & 79 & 71 & 66 & 81 & 81 & 82 & 85 & 79 \\
\hline
\end{tabular}

1: These data were not collected in 2011 as the sector looked identical to 2010 and had little wetland plant growth. 
Table 4.7. ANOVA results for comparison of treatment and sector effects in the fen meadow zone at the Marsin and Sand Point restoration sites in late summer 2011. Sector refers to the three sampling sectors; "lakeside", "middle" and "upper". Treat is treatment type - peat addition or no peat addition.

\section{Data}

\begin{tabular}{|c|c|c|c|c|c|c|c|}
\hline Site Restoration Parameter & $\begin{array}{l}\text { Root } \\
\text { MSE }\end{array}$ & $\begin{array}{c}\text { y1 } \\
\text { Mean }\end{array}$ & $\begin{array}{l}\text { y1 F- } \\
\text { stat }\end{array}$ & $\begin{array}{l}\text { y1 P- } \\
\text { value }\end{array}$ & $\begin{array}{c}\text { Sector P- } \\
\text { val }\end{array}$ & $\begin{array}{c}\text { Treat P- } \\
\text { val }\end{array}$ & $\mathbf{R}^{2}$ \\
\hline \multicolumn{8}{|l|}{ Marsin } \\
\hline Wetland Plant Vegetative Cover & 36 & 86 & 3.7 & $0.013^{*}$ & 0.11 & $0.01^{*}$ & 0.07 \\
\hline Wetland Plant Diversity & 2.5 & 9 & 4.5 & $0.005^{*}$ & $0.002 *$ & 0.35 & 0.09 \\
\hline
\end{tabular}

$\begin{aligned} & \text { Sand Point } \\
& \text { Wetland Plant Vegetative Cover }\end{aligned}$
\begin{tabular}{rllllllll} 
& 30 & 55 & 102 & $<.0001^{*}$ & $<.0001^{*}$ & 0.28 & 0.68 \\
Wetland Plant Diversity & 2 & 4 & 73 & $<.0001^{*}$ & $<.0001^{*}$ & 0.30 & 0.60 \\
\hline
\end{tabular}


Table 4.8. Percent cover values for select wetland plant species in the emergent log and fen meadow zones at the Marsin and Sand Point restoration sites in late summer 2011. ${ }^{1}$

\begin{tabular}{|c|c|c|c|c|c|c|c|c|c|c|c|c|c|c|c|c|c|c|c|c|}
\hline \multirow[b]{4}{*}{ Plant Species } & \multicolumn{10}{|c|}{ Marsin 2011} & \multicolumn{10}{|c|}{ Sand Point 2011} \\
\hline & \multirow{2}{*}{\multicolumn{2}{|c|}{$\begin{array}{c}\text { Emergent }^{2} \\
\text { Logs }\end{array}$}} & \multicolumn{6}{|c|}{ Fen Meadow Sectors } & \multirow{2}{*}{\multicolumn{2}{|c|}{$\begin{array}{c}\text { Meadow } \\
\text { Totals }\end{array}$}} & \multirow{2}{*}{\multicolumn{2}{|c|}{$\begin{array}{c}\text { Emergent } \\
\text { Logs }\end{array}$}} & \multicolumn{6}{|c|}{ Fen Meadow Sectors } & \multirow{2}{*}{\multicolumn{2}{|c|}{$\begin{array}{c}\text { Meadow } \\
\text { Totals }\end{array}$}} \\
\hline & & & \multicolumn{2}{|c|}{ Lakeside } & \multicolumn{2}{|c|}{ Middle } & \multicolumn{2}{|c|}{ Upper } & & & & & \multicolumn{2}{|c|}{ Lakeside } & \multicolumn{2}{|c|}{ Middle } & \multicolumn{2}{|c|}{ Upper $^{3}$} & & \\
\hline & $\mathbf{P}$ & $\mathbf{N}$ & $\mathbf{P}$ & $\mathbf{N}$ & $\mathbf{P}$ & $\mathbf{N}$ & $\mathbf{P}$ & $\mathbf{N}$ & $\mathbf{P}$ & $\mathbf{N}$ & $\mathbf{P}$ & $\mathbf{N}$ & $\mathbf{P}$ & $\mathbf{N}$ & $\mathbf{P}$ & $\mathbf{N}$ & $\mathbf{P}$ & $\mathbf{N}$ & $\mathbf{P}$ & $\mathbf{N}$ \\
\hline Agrostis perennans & & & & $1 \%$ & $1 \%$ & $2 \%$ & & $1 \%$ & $1 \%$ & $1 \%$ & & & $2 \%$ & $5 \%$ & $13 \%$ & $14 \%$ & & & $7 \%$ & $8 \%$ \\
\hline Asclepias incarnata & & & & & & & & & & & & & & & $3 \%$ & & & & $2 \%$ & \\
\hline Bidens frondosa & & & $6 \%$ & $3 \%$ & $4 \%$ & $2 \%$ & $2 \%$ & $3 \%$ & $4 \%$ & $3 \%$ & $2 \%$ & $3 \%$ & $4 \%$ & $3 \%$ & $4 \%$ & $3 \%$ & & & $4 \%$ & $3 \%$ \\
\hline Calamagrostis canadensis & & & $1 \%$ & $1 \%$ & $2 \%$ & $1 \%$ & $2 \%$ & & $2 \%$ & $1 \%$ & & & $1 \%$ & & & & & & $1 \%$ & \\
\hline Carex stricta & & & $5 \%$ & $3 \%$ & $4 \%$ & $4 \%$ & $4 \%$ & $6 \%$ & $5 \%$ & $4 \%$ & & & $4 \%$ & $4 \%$ & $1 \%$ & $1 \%$ & & & $2 \%$ & $2 \%$ \\
\hline Cyperaceae spp. & & & $34 \%$ & $25 \%$ & $37 \% 2$ & $25 \% 3$ & $32 \% 2$ & $24 \% 3$ & $34 \% 2$ & $25 \%$ & $36 \%$ & $13 \%$ & $8 \%$ & $5 \%$ & $7 \%$ & $3 \%$ & & & $17 \%$ & $7 \%$ \\
\hline Doellingeria umbellata & & & $6 \%$ & $4 \%$ & $7 \%$ & $8 \%$ & $5 \%$ & $7 \%$ & $6 \%$ & $6 \%$ & & & & & $3 \%$ & $2 \%$ & & & $2 \%$ & $1 \%$ \\
\hline Eleocharis acicularis & & & & & & & & & & & & & & & $23 \%$ & $55 \%$ & & & $16 \%$ & $27 \%$ \\
\hline Epilobium sp. & & & $1 \%$ & $1 \%$ & & $2 \%$ & & & & $1 \%$ & & & & & & & & & & \\
\hline Eupatorium perfoliatum & & & & & & & & & & & & & & & & $1 \%$ & & & & $1 \%$ \\
\hline Euthamia graminifolia & & & & & & & & & & & & & & & $2 \%$ & & & & $1 \%$ & \\
\hline feather moss sp. & & & & & & & & & & & & & & & & $2 \%$ & & & & $1 \%$ \\
\hline Iris versicolor ${ }^{4}$ & & & $5 \%$ & $1 \%$ & $7 \%$ & $4 \%$ & $5 \%$ & $3 \%$ & $6 \%$ & $3 \%$ & $11 \%$ & $12 \%$ & $1 \%$ & $1 \%$ & $3 \%$ & & & & $2 \%$ & $1 \%$ \\
\hline Juncus arcticus & & & $2 \%$ & & & & & & $1 \%$ & & & & $2 \%$ & $2 \%$ & $12 \%$ & $14 \%$ & & & $7 \%$ & $8 \%$ \\
\hline Juncus effusus & & & $6 \%$ & $4 \%$ & $1 \%$ & & $2 \%$ & $1 \%$ & $3 \%$ & $2 \%$ & & & & & & $1 \%$ & & & & $1 \%$ \\
\hline Juncus spp. & & & $12 \%$ & $14 \%$ & $17 \%$ & $14 \% 1$ & $16 \% 1$ & $15 \%$ & $15 \% 1$ & $14 \%$ & $5 \%$ & $2 \%$ & $2 \%$ & $6 \%$ & $21 \%$ & $16 \%$ & & & $16 \%$ & $11 \%$ \\
\hline Lycopus spp. & & & $2 \%$ & $2 \%$ & $2 \%$ & $5 \%$ & $2 \%$ & $4 \%$ & $2 \%$ & $4 \%$ & & & & & $3 \%$ & $5 \%$ & & & $2 \%$ & $3 \%$ \\
\hline Persicaria pensylvanica & & & & & & & & & & & & & & $1 \%$ & & & & & & $1 \%$ \\
\hline Phalaris arundinacea & & & $3 \%$ & $2 \%$ & $3 \%$ & $2 \%$ & $1 \%$ & $1 \%$ & $2 \%$ & $2 \%$ & & & & & & & & & & \\
\hline Physocarpus opulifolius & & & & $2 \%$ & $2 \%$ & & $1 \%$ & $1 \%$ & $1 \%$ & $1 \%$ & & & & & & & & & & \\
\hline Potentilla norvegica & & & $1 \%$ & $1 \%$ & $2 \%$ & $4 \%$ & $1 \%$ & $1 \%$ & $1 \%$ & $2 \%$ & & & & & & & & & & \\
\hline Sagittaria latifolia & & & & & & & & & & & & & $3 \%$ & $1 \%$ & & & & & $2 \%$ & $1 \%$ \\
\hline Solidago uliginosa & & & $5 \%$ & $4 \%$ & $5 \%$ & $5 \%$ & $6 \%$ & $5 \%$ & $5 \%$ & $5 \%$ & & & & & & & & & & \\
\hline Spirea alba & & & & & & & & & & & & & & & $1 \%$ & & & & $1 \%$ & \\
\hline Symphyotrichum puniceum & & & $1 \%$ & & & & & & $1 \%$ & & & & & $1 \%$ & & & & & $1 \%$ & \\
\hline Thalictrum dasycarpum & & & $1 \%$ & $2 \%$ & $2 \%$ & $2 \%$ & $1 \%$ & $1 \%$ & $1 \%$ & $1 \%$ & & & & & $2 \%$ & $2 \%$ & & & $1 \%$ & $1 \%$ \\
\hline Total Cover & & & $91 \%$ & $70 \% \varsigma$ & $96 \% \varepsilon$ & $80 \% \&$ & $80 \% 7$ & $73 \% ؟$ & $90 \% 7$ & 75\% & $54 \%$ & $30 \%$ & $27 \% 2$ & $29 \% \subsetneq$ & $98 \%$ & $119 \%$ & $0 \%$ & $0 \%$ & $84 \%$ & $77 \%$ \\
\hline \multicolumn{21}{|c|}{$\begin{array}{l}\text { 1: Only wetland plant species with } 1 \% \text { total cover or greater are included. For species with } 0.5-0.99 \% \text { cover per zone, value was } \\
\text { rounded up to } 1 \% . \mathrm{P}=\text { peat plots } / \text { logs and } \mathrm{N}=\text { no peat plots/logs. }\end{array}$} \\
\hline \multicolumn{21}{|c|}{ 2: All vegetation on Marsin site emergent logs died in spring of 2011 due to low lake levels. } \\
\hline $\begin{array}{l}\text { 3: Data were not collected } \mathrm{i} \\
\text { vegetation development. }\end{array}$ & in $u$ & & ector & at Sa & and $\mathrm{Pc}_{\mathrm{C}}$ & Point $\mathrm{i}$ & in 201 & 11 as & s the & con & רs & oked & & same & as in & 201 & & & & tland \\
\hline
\end{tabular}


Table 4.9. Plant species richness in the emergent log and fen meadow zones at the Marsin and Sand Point restoration sites in late summer $2011{ }^{1}$

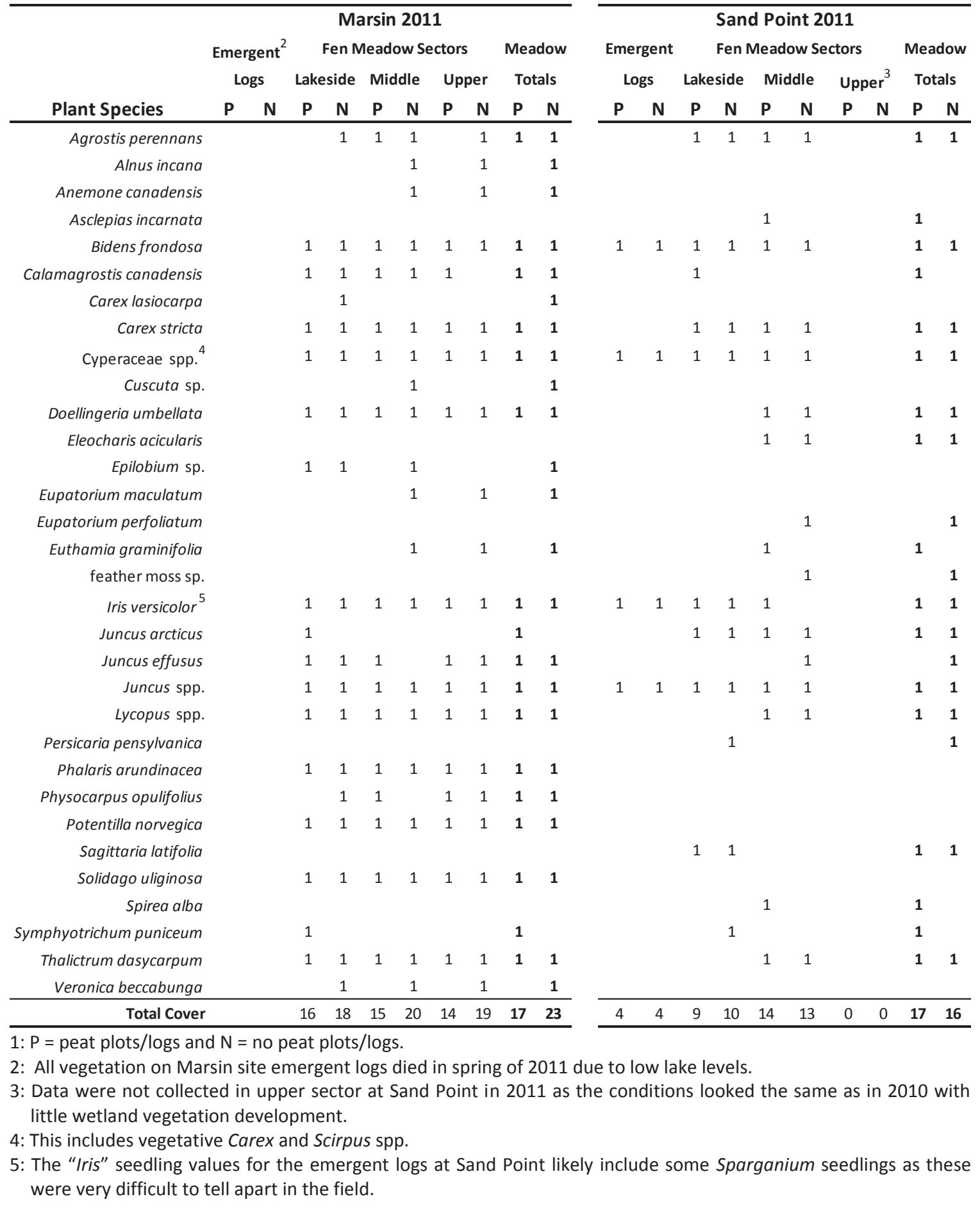


Table 4.10. Carex stricta survivorship in the fen meadow zone at the A) Marsin Center and B) Sand Point restoration sites in late summer 2011.

\section{A. Marsin Center}

\begin{tabular}{|c|c|c|c|c|c|c|c|c|c|c|c|c|}
\hline \multirow[b]{3}{*}{ Zone } & \multicolumn{10}{|c|}{ Block and Treatment } & \multirow{2}{*}{\multicolumn{2}{|c|}{$\begin{array}{c}\text { Treatment } \\
\& \\
\text { Zone Totals }\end{array}$}} \\
\hline & 1 & 2 & 3 & 4 & 5 & 6 & 7 & 8 & 9 & 10 & & \\
\hline & Peat & $\begin{array}{c}\text { No } \\
\text { Peat }\end{array}$ & Peat & $\begin{array}{c}\text { No } \\
\text { Peat }\end{array}$ & Peat & $\begin{array}{c}\text { No } \\
\text { Peat }\end{array}$ & Peat & $\begin{array}{c}\text { No } \\
\text { Peat }\end{array}$ & Peat & $\begin{array}{c}\text { No } \\
\text { Peat }\end{array}$ & Peat & $\begin{array}{l}\text { No } \\
\text { Peat }\end{array}$ \\
\hline Lakeside & 6 & 4 & 7 & 8 & 5 & 6 & 1 & 6 & 2 & 8 & 21 & 32 \\
\hline Mid-Plot & 3 & 5 & 7 & 8 & 6 & 6 & 2 & 6 & 3 & 7 & 21 & 32 \\
\hline Upper & 7 & 8 & 7 & 8 & 8 & 5 & 6 & 4 & 4 & 8 & 32 & 33 \\
\hline k Totals: & 16 & 17 & 21 & 24 & 19 & 17 & 9 & 16 & 9 & 23 & 74 & 97 \\
\hline
\end{tabular}

\section{B. Sand Point}

\begin{tabular}{|c|c|c|c|c|c|c|c|c|c|c|c|c|}
\hline \multirow[b]{3}{*}{ Zone } & \multicolumn{10}{|c|}{ Block and Treatment } & \multirow{2}{*}{\multicolumn{2}{|c|}{$\begin{array}{c}\text { Treatment } \\
\text { \& } \\
\text { Zone Totals }\end{array}$}} \\
\hline & 1 & 2 & 3 & 4 & 5 & 6 & 7 & 8 & 9 & 10 & & \\
\hline & Peat & $\begin{array}{l}\text { No } \\
\text { Peat }\end{array}$ & Peat & $\begin{array}{l}\text { No } \\
\text { Peat }\end{array}$ & Peat & $\begin{array}{l}\text { No } \\
\text { Peat }\end{array}$ & Peat & $\begin{array}{l}\text { No } \\
\text { Peat }\end{array}$ & Peat & $\begin{array}{l}\text { No } \\
\text { Peat }\end{array}$ & Peat & $\begin{array}{l}\text { No } \\
\text { Peat }\end{array}$ \\
\hline Lakeside & 7 & 8 & 4 & 6 & 6 & 4 & 7 & 4 & 7 & 8 & 31 & 30 \\
\hline Mid-Plot & 1 & 4 & 3 & 4 & 4 & 3 & 0 & 7 & 4 & 2 & 12 & 20 \\
\hline Upper & 0 & 1 & 0 & 0 & 0 & 0 & 0 & 0 & 3 & 0 & 3 & 1 \\
\hline Block Totals: & 8 & 13 & 7 & 10 & 10 & 7 & 7 & 11 & 14 & 10 & 46 & 51 \\
\hline
\end{tabular}


Table 4.11. Percent cover values for select wetland plants in the emergent log and fen meadow zones at the Marsin and Sand Point restoration sites in late summer 2013. ${ }^{1}$

\begin{tabular}{|c|c|c|c|c|c|c|c|c|c|c|c|c|c|c|c|c|c|c|c|c|}
\hline \multirow[b]{4}{*}{ Plant Species } & \multicolumn{10}{|c|}{ Marsin 2013} & \multicolumn{10}{|c|}{ Sand Point 2013} \\
\hline & \multirow{2}{*}{\multicolumn{2}{|c|}{$\begin{array}{c}\text { Emergent }^{2} \\
\text { Logs }\end{array}$}} & \multicolumn{6}{|c|}{ Fen Meadow Sectors } & \multirow{2}{*}{\multicolumn{2}{|c|}{$\begin{array}{c}\text { Meadow } \\
\text { Totals }\end{array}$}} & \multirow{2}{*}{\multicolumn{2}{|c|}{$\begin{array}{c}\text { Emergent } \\
\text { Logs }\end{array}$}} & \multicolumn{6}{|c|}{ Fen Meadow Sectors } & \multirow{2}{*}{\multicolumn{2}{|c|}{$\begin{array}{c}\text { Meadow } \\
\text { Totals }\end{array}$}} \\
\hline & & & \multicolumn{2}{|c|}{ Lakeside } & \multicolumn{2}{|c|}{ Middle } & \multicolumn{2}{|c|}{ Upper } & & & & & Lake & eside & Mid & ddle & Upr & per & & \\
\hline & $\mathbf{P}$ & $\mathbf{N}$ & $\mathbf{P}$ & $\mathbf{N}$ & $\mathbf{P}$ & $\mathbf{N}$ & $\mathbf{P}$ & $\mathbf{N}$ & $\mathbf{P}$ & $\mathbf{N}$ & $\mathbf{P}$ & $\mathbf{N}$ & $\mathbf{P}$ & $\mathbf{N}$ & $\mathbf{P}$ & $\mathbf{N}$ & $\mathbf{P}$ & $\mathbf{N}$ & $\mathbf{P}$ & $\mathbf{N}$ \\
\hline Agrostis scabra & & & & & & & & & & & & & & & $1 \%$ & $2 \%$ & $2 \%$ & $2 \%$ & $1.0 \%$ & $1.3 \%$ \\
\hline Agrostis perennans & & & $1 \%$ & $1 \%$ & & $1 \%$ & & & $0.3 \%$ & $0.7 \%$ & & & & & & $1 \%$ & & $2 \%$ & $0.0 \%$ & $1.0 \%$ \\
\hline Asclepias incarnata & & & $1 \%$ & & & & & & $0.3 \%$ & & & & $2 \%$ & $1 \%$ & $9 \%$ & $4 \%$ & $4 \%$ & & $4.3 \%$ & $1.7 \%$ \\
\hline Calamagrostis canadensis & & & $2 \%$ & $2 \%$ & $1 \%$ & $1 \%$ & $2 \%$ & $3 \%$ & $1.7 \%$ & $2.0 \%$ & & & & & & $1 \%$ & $1 \%$ & $5 \%$ & $0.3 \%$ & $2.0 \%$ \\
\hline Carex comosa $^{3}$ & & & $1 \%$ & $2 \%$ & $1 \%$ & $2 \%$ & & $1 \%$ & $0.7 \%$ & $1.7 \%$ & $64 \%$ & $50 \%$ & $1 \%$ & $1 \%$ & & $5 \%$ & & & $21 \%$ & $2.0 \%$ \\
\hline Carex lasiocarpa & & & & $1 \%$ & & & & & & $0.3 \%$ & & & & & & & & & $0.0 \%$ & $0.0 \%$ \\
\hline Carex projecta & & & $4 \%$ & $6 \%$ & $6 \%$ & $1 \%$ & $10 \%$ & $11 \%$ & $6.7 \%$ & $6.0 \%$ & & & $2 \%$ & & $4 \%$ & $7 \%$ & $5 \%$ & $8 \%$ & $3.0 \%$ & $5.0 \%$ \\
\hline Carex scoparia & & & $1 \%$ & $1 \%$ & & $9 \%$ & $1 \%$ & $1 \%$ & $0.7 \%$ & $3.7 \%$ & $1 \%$ & & $3 \%$ & & & & $1 \%$ & & $0.7 \%$ & $0.0 \%$ \\
\hline Carex stipata & & & $1 \%$ & & & $2 \%$ & & & $0.3 \%$ & $0.7 \%$ & & & & & & & & & $0.0 \%$ & $0.0 \%$ \\
\hline Carex stricta & & & & & & $1 \%$ & $1 \%$ & $1 \%$ & $0.3 \%$ & $0.7 \%$ & $2 \%$ & $1 \%$ & $2 \%$ & $2 \%$ & $2 \%$ & & $1 \%$ & & $1.7 \%$ & $0.7 \%$ \\
\hline Carex spp. & & & & & & $1 \%$ & & & $3.0 \%$ & $0.3 \%$ & & & & & & & & & $0.0 \%$ & $0.0 \%$ \\
\hline Doellingeria umbellata & & & $2 \%$ & $4 \%$ & $2 \%$ & $5 \%$ & $5 \%$ & $6 \%$ & & $5.0 \%$ & & & & & $1 \%$ & & $1 \%$ & & $0.7 \%$ & $0.0 \%$ \\
\hline Eleocharis acicularis & & & & & & & & & & & & & $1 \%$ & $1 \%$ & $1 \%$ & $1 \%$ & & & $0.3 \%$ & $0.7 \%$ \\
\hline Eleocharis palustris & & & & & & & & & & & $1 \%$ & $1 \%$ & $7 \%$ & $7 \%$ & & & & & $0.3 \%$ & $2.3 \%$ \\
\hline Epilobium sp. & & & & & & & & & $0.3 \%$ & & & & & & & & & & $0.0 \%$ & $0.0 \%$ \\
\hline Equisetum sp. & & & & & & & $1 \%$ & & $1.0 \%$ & & & & & & & & & & $0.0 \%$ & $0.0 \%$ \\
\hline Eupatorium maculatum & & & $3 \%$ & $2 \%$ & & $2 \%$ & & $1 \%$ & $0.0 \%$ & $1.7 \%$ & & & & & & & & & $0.0 \%$ & $0.0 \%$ \\
\hline Eupatorium perfoliatum & & & & & & & & & $1.0 \%$ & $0.0 \%$ & & & & & & & & & $0.0 \%$ & $0.0 \%$ \\
\hline Euthamia graminifolia & & & $1 \%$ & & $1 \%$ & $1 \%$ & $1 \%$ & $1 \%$ & & $0.7 \%$ & & & & $1 \%$ & $1 \%$ & & & & $0.3 \%$ & $0.3 \%$ \\
\hline Iris versicolor ${ }^{4}$ & & & $8 \%$ & $7 \%$ & $9 \%$ & $5 \%$ & $6 \%$ & $4 \%$ & $2.0 \%$ & $5.3 \%$ & $15 \%$ & $14 \%$ & $3 \%$ & $1 \%$ & $4 \%$ & $3 \%$ & & & $6 \%$ & $1.3 \%$ \\
\hline Juncus arcticus & & & $4 \%$ & $10 \%$ & $2 \%$ & $2 \%$ & & & $12 \%$ & $4.0 \%$ & & & $2 \%$ & $3 \%$ & $11 \%$ & $14 \%$ & $9 \%$ & $6 \%$ & $7 \%$ & $7.7 \%$ \\
\hline Juncus effusus & & & $26 \%$ & $18 \%$ & $6 \%$ & $6 \%$ & $3 \%$ & $4 \%$ & $14 \%$ & $9.3 \%$ & $2 \%$ & & $4 \%$ & $1 \%$ & $2 \%$ & $2 \%$ & & $2 \%$ & $1.3 \%$ & $1.7 \%$ \\
\hline Juncus spp. & & & $13 \%$ & $19 \%$ & $16 \%$ & $18 \%$ & $13 \%$ & $11 \%$ & $2.3 \%$ & $16.0 \%$ & $12 \%$ & $7 \%$ & $18 \%$ & $21 \%$ & $14 \%$ & $10 \%$ & $2 \%$ & $2 \%$ & $9 \%$ & $11 \%$ \\
\hline Lycopus spp. & & & $3 \%$ & $6 \%$ & $2 \%$ & $3 \%$ & $2 \%$ & $3 \%$ & $3.7 \%$ & $4.0 \%$ & & & $1 \%$ & $1 \%$ & $5 \%$ & $5 \%$ & & $1 \%$ & $1.7 \%$ & $2.3 \%$ \\
\hline Myrica gale & & & $1 \%$ & $2 \%$ & $6 \%$ & $4 \%$ & $4 \%$ & $5 \%$ & & $3.7 \%$ & & & & & & & & & $0.0 \%$ & $0.0 \%$ \\
\hline Persicaria sagittata & & & & & $1 \%$ & & & & $1.3 \%$ & & & & & & & & & & $0.0 \%$ & $0.0 \%$ \\
\hline Phalaris arundinacea & & & $3 \%$ & $3 \%$ & $1 \%$ & $4 \%$ & & $1 \%$ & & $2.7 \%$ & & & & & & & & & $0.0 \%$ & $0.0 \%$ \\
\hline Sagittaria latifolia & & & & & & & & & & & $1 \%$ & & & & & & & & $0.3 \%$ & $0.0 \%$ \\
\hline Scirpus atrovirens & & & & & & & & & $0.3 \%$ & & $9 \%$ & $11 \%$ & $2 \%$ & & $1 \%$ & & $3 \%$ & & $4.3 \%$ & $0.0 \%$ \\
\hline Scirpus cyperinus & & & $1 \%$ & $1 \%$ & & & & & $3.3 \%$ & $0.3 \%$ & $4 \%$ & & $2 \%$ & & $3 \%$ & & $2 \%$ & & $3.0 \%$ & $0.0 \%$ \\
\hline Solidago uliginosa & & & $1 \%$ & $2 \%$ & $2 \%$ & $5 \%$ & $7 \%$ & $9 \%$ & & $5.3 \%$ & & & & & & & & & $0.0 \%$ & $0.0 \%$ \\
\hline Spiranthes cernua & & & & & & & & & & & & & & & $1 \%$ & $1 \%$ & $1 \%$ & & $0.7 \%$ & $0.3 \%$ \\
\hline Spirea alba & & & & & & & & & $0.7 \%$ & & & & & & $1 \%$ & $1 \%$ & & & $0.3 \%$ & $0.3 \%$ \\
\hline Symphyotrichum puniceum & & & $1 \%$ & & & & $1 \%$ & & & $0.0 \%$ & & & & & $1 \%$ & $1 \%$ & & & $0.3 \%$ & $0.3 \%$ \\
\hline Triadenum frasieri & & & & & & & & & & & & & & & & $1 \%$ & & & & $0.3 \%$ \\
\hline Total Cover & & & $78 \%$ & $87 \%$ & $56 \%$ & $73 \%$ & $57 \%$ & $62 \%$ & $56 \%$ & $74 \%$ & $111 \%$ & $84 \%$ & $50 \%$ & $40 \%$ & $62 \%$ & $59 \%$ & $32 \%$ & $28 \%$ & $68 \%$ & $42 \%$ \\
\hline
\end{tabular}

1: Only wetland plant species with $1 \%$ total cover or greater are included. For species with $0.5-0.99 \%$ cover per zone, value was rounded up to $1 \%$. $P=$ peat plots $/$ logs and $N=$ no peat plots $/$ logs.

2: All vegetation on Marsin site emergent logs died in spring of 2011 due to low lake levels.

3: These values likely include $C$. pseudocyperus vegetation.

4: The "Iris" seedling values for the emergent logs at Sand Point likely include some Sparganium seedlings as these were very difficult to tell apart in the field. 
Table 4.12. Total plant species richness in the emergent log and fen meadow zones at the Marsin and Sand Point restoration sites in late summer $2013 .{ }^{1}$

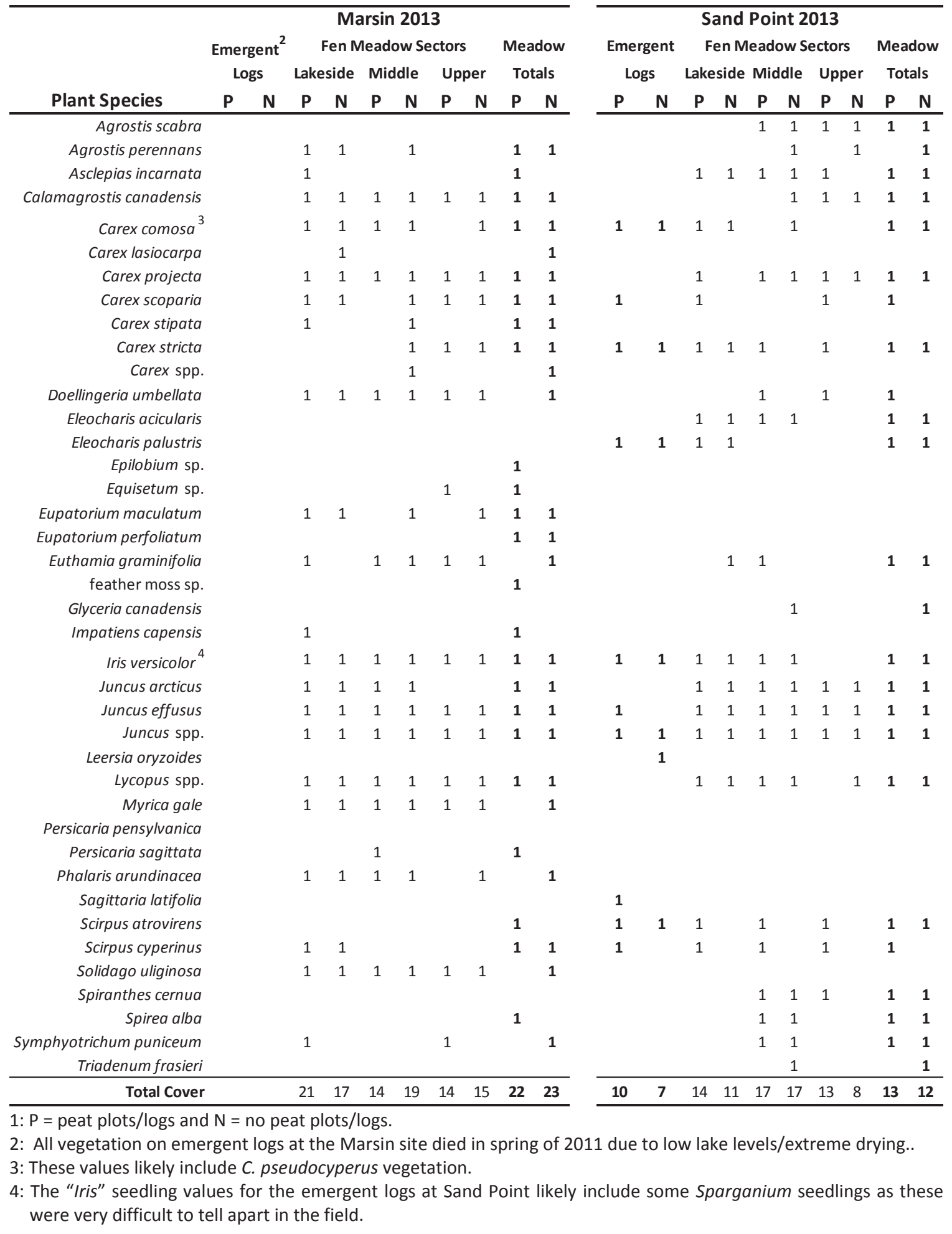


Table 4.13. Vegetative cover in the emergent log and fen meadow zones at the A) Marsin and B) Sand Point restoration sites in late summer 2013.

\begin{tabular}{|c|c|c|c|c|c|c|c|c|c|c|c|c|}
\hline \multicolumn{13}{|l|}{ A. Marsin } \\
\hline \multirow[b]{2}{*}{ Zone/Sector } & \multicolumn{6}{|c|}{ Peat Plots/Logs } & \multicolumn{6}{|c|}{ No Peat Plots/Logs } \\
\hline & 1 & 2 & 3 & 4 & 5 & Ave. & 1 & 2 & 3 & 4 & 5 & Ave. \\
\hline Emergent & 0 & 0 & 0 & 0 & 0 & 0 & 0 & 0 & 0 & 0 & 0 & 0 \\
\hline \multicolumn{13}{|l|}{ Wet Meadow } \\
\hline Lakeside & 91 & 78 & 66 & 46 & 32 & 63 & 129 & 74 & 68 & 84 & 84 & 88 \\
\hline Middle & 53 & 83 & 68 & 53 & 76 & 67 & 58 & 78 & 47 & 55 & 73 & 62 \\
\hline Upper & 69 & 56 & 94 & 56 & 81 & 71 & 73 & 65 & 73 & 96 & 110 & 83 \\
\hline Meadow Average & 71 & 72 & 76 & 52 & 63 & 67 & 87 & 72 & 63 & 78 & 89 & 78 \\
\hline
\end{tabular}

\section{B. Sand Point}

\begin{tabular}{|c|c|c|c|c|c|c|c|c|c|c|c|c|}
\hline \multirow[b]{2}{*}{ Zone/Sector } & \multicolumn{6}{|c|}{ Peat Plots/Logs } & \multicolumn{6}{|c|}{ No Peat Plots/Logs } \\
\hline & 1 & 2 & 3 & 4 & 5 & Ave. & 1 & 2 & 3 & 4 & 5 & Ave. \\
\hline Emergent & 117 & 99 & 121 & 106 & 113 & 111 & 102 & 96 & 72 & 62 & 114 & 89 \\
\hline \multicolumn{13}{|l|}{ Wet Meadow } \\
\hline Lakeside & 39 & 34 & 80 & 31 & 71 & 51 & 28 & 51 & 51 & 36 & 39 & 41 \\
\hline Middle & 63 & 78 & 65 & 66 & 55 & 65 & 56 & 66 & 52 & 78 & 68 & 64 \\
\hline Upper & 6 & 23 & 16 & 47 & 65 & 31 & 6 & 41 & 25 & 55 & 42 & 34 \\
\hline Meadow Average & 36 & 45 & 54 & 48 & 64 & 49 & 30 & 53 & 43 & 56 & 50 & 46 \\
\hline
\end{tabular}


Table 4.14. ANOVA results for comparison of treatment and sector effects in the fen meadow zone at the Marsin and Sand Point restoration sites in late summer 2013. Sector refers to the three sampling sectors; "lakeside", "middle" and "upper". Treat is treatment type - peat addition or no peat addition.

\begin{tabular}{|c|c|c|c|c|c|c|c|}
\hline \multirow[b]{2}{*}{ Restoration Parameter } & \multicolumn{6}{|c|}{$\begin{array}{c}2013 \text { Marsin and Sand Point Vegetation } \\
\text { ANOVA Results }\end{array}$} & \multirow[b]{2}{*}{$\mathbf{R}^{2}$} \\
\hline & $\begin{array}{l}\text { Root } \\
\text { MSE }\end{array}$ & $\begin{array}{c}\text { y1 } \\
\text { Mean }\end{array}$ & $\begin{array}{l}\text { y1 F- } \\
\text { stat }\end{array}$ & $\begin{array}{l}\text { y1 } P \text { - } \\
\text { value }\end{array}$ & $\begin{array}{c}\text { Sector } \\
\text { P-val }\end{array}$ & $\begin{array}{c}\text { Treat P- } \\
\text { val }\end{array}$ & \\
\hline Marsin Vegetative Cover & 25 & 71 & 8.3 & $<.0001^{*}$ & $0.0002^{*}$ & $0.009 *$ & \\
\hline Marsin Wetland Plant Diversity & 2 & 6.7 & 2.4 & 0.07 & $0.03 *$ & 0.64 & 0.05 \\
\hline Sand Point Vegetative Cover & 22 & 47 & 19 & $<.0001^{*}$ & $<.0001^{*}$ & 0.27 & 0.28 \\
\hline Sand Point Wetland Plant Diversity & 1.6 & 3.5 & 23 & $<.0001^{*}$ & $<.0001^{*}$ & 0.72 & 0.32 \\
\hline
\end{tabular}


Appendix 4.1 Permission regarding use of Bing Maps images, Google Earth images and previously published material in the dissertation of James A. Bess.

United States copyright law allows for the "Fair Use" of copyrighted material in works of scholarship, such as a doctoral dissertation. Neither Bing Maps nor Google Earth provides individual clearance for use of their copyrighted materials and this determination is left up to the "end user". Only a single, screen-capture image was used from each service (Figure 2.1 and 3.1 from Bing Maps and Figure 4.1 from Google Earth) and both were modified to varying degrees to show pertinent features related to the relevant research projects. Both companies have been referenced in the captions and their company logos included on each figure. For the previously published chapter 2 , permission was requested from the journal Ecological Restoration and their permission letter is attached below. 
James Bess

Michigan Technological University

Dear James Bess:

Thank you for your request to reprint "Ditch Restoration in a Large Northern Michigan Fen: Vegetation Response and Basic Pore Water Chemistry." 32.3 (2014): 260-274 from Ecological Restoration, in your forthcoming work doctoral dissertation to be published by Michigan Technological University.

The University of Wisconsin Press is always pleased to grant to an author free use of his or her own material. The rights hereby granted are non-exclusive, world-wide, for print and e-book versions, and for all editions of the work you described. Further use of this material, except in those versions adapted for blind or handicapped individuals, will require a separate request.

Our suggested acknowledgment:

Bess, J., R. Chimner, and L. Kangas. "Ditch Restoration in a Large Northern Michigan Fen: Vegetation Response and Basic Pore Water Chemistry." Ecological Restoration 32.3 (2014): 260 -274 . (5) 2014 by the Board of Regents of the University of Wisconsin System. Reproduced by the permission of the University of Wisconsin Press.

(fyou have made any revisions $\mathrm{h}$ your work, you may wish to add a phrase to that effect.)

This permission does not apply to anything in our publication credited to another source.

Sincerely.

Joelle E. Tybon

Permissions Assistant to Anne T. McKenna

University of Wisconsin Press

Subsidiary Rights \& Permissions

rights@uwpress.wise.edu

PH 608-263-1132 